\title{
Preliminary classification of Leotiomycetes
}

\section{Ekanayaka AH ${ }^{1,2}$, Hyde $\mathrm{KD}^{1,2}$, Gentekaki $\mathbf{E}^{2,3}$, McKenzie EHC ${ }^{4}$, Zhao $\mathbf{Q}^{1, *}$, Bulgakov TS ${ }^{5}$, Camporesi $\mathrm{E}^{6,7}$}

\author{
${ }^{1}$ Key Laboratory for Plant Diversity and Biogeography of East Asia, Kunming Institute of Botany, Chinese Academy of \\ Sciences, Kunming 650201, Yunnan, China \\ ${ }^{2}$ Center of Excellence in Fungal Research, Mae Fah Luang University, Chiang Rai, 57100, Thailand \\ ${ }^{3}$ School of Science, Mae Fah Luang University, Chiang Rai, 57100, Thailand \\ ${ }^{4}$ Landcare Research Manaaki Whenua, Private Bag 92170, Auckland, New Zealand \\ ${ }^{5}$ Russian Research Institute of Floriculture and Subtropical Crops, 2/28 Yana Fabritsiusa Street, Sochi 354002, \\ Krasnodar region, Russia \\ ${ }^{6}$ A.M.B. Gruppo Micologico Forlivese “Antonio Cicognani”, Via Roma 18, Forlì, Italy. \\ ${ }^{7}$ A.M.B. Circolo Micologico "Giovanni Carini”, C.P. 314 Brescia, Italy.
}

Ekanayaka AH, Hyde KD, Gentekaki E, McKenzie EHC, Zhao Q, Bulgakov TS, Camporesi E 2019 - Preliminary classification of Leotiomycetes. Mycosphere 10(1), 310-489, Doi 10.5943/mycosphere/10/1/7

\begin{abstract}
Leotiomycetes is regarded as the inoperculate class of discomycetes within the phylum Ascomycota. Taxa are mainly characterized by asci with a simple pore blueing in Melzer's reagent, although some taxa have lost this character. The monophyly of this class has been verified in several recent molecular studies. However, circumscription of the orders, families and generic level delimitation are still unsettled. This paper provides a modified backbone tree for the class Leotiomycetes based on phylogenetic analysis of combined ITS, LSU, SSU, TEF, and RPB2 loci. In the phylogenetic analysis, Leotiomycetes separates into 19 clades, which can be recognized as orders and order-level clades. Leotiomycetes include 53 families (Ascodichaenaceae, Amicodiscaceae fam. nov., Amorphothecaceae, Arachnopezizaceae, Ascocorticiaceae, Calloriaceae, Cenangiaceae, Chaetomellaceae, Chlorociboriaceae, Chlorospleniaceae fam. nov., Bryoglossaceae fam. nov., Cochlearomycetaceae, Cordieritidaceae, Cyttariaceae, Deltopyxidaceae fam. nov., Dermateaceae, Discinellaceae fam. nov., Drepanopezizaceae, Erysiphaceae, Gelatinodiscaceae, Godroniaceae, Hamatocanthoscyphaceae fam. nov., Helicogoniaceae, Helotiaceae, Hemiphacidiaceae, Heterosphaeriaceae, Hyaloscyphaceae, Hydrocinaceae fam. nov., Hyphodiscaceae fam. nov., Lachnaceae, Lahmiaceae, Lauriomycetaceae, Leotiaceae, Leptodontidiaceae, Lichinodiaceae, Loramycetaceae, Marthamycetaceae, Medeolariaceae, Mitrulaceae, Mollisiaceae, Neocrinulaceae, Neolauriomycetaceae, Pezizellaceae, Phacidiaceae, Ploettnerulaceae, Rhytismataceae, Rutstroemiaceae, Sclerotiniaceae, Solenopeziaceae fam. nov., Thelebolaceae, Triblidiaceae, Tympanidaceae and Vibrisseaceae) and 14 family-level clades (Alatospora-Miniancora clade, Aquapoterium-Unguicularia clade, Bulgariella clade, ColeophomaParafabraea clade, Colipila clade, Corticifraga-Calloriopsis clade, Epicladonia-Epithamnolia clade, Flagellospora clade, Gelatinomyces clade, Micraspis clade, Patellariopsis clade, Phialocephala urceolata clade, Peltigeromyces clade and Trizodia clade). We briefly discuss the phylogenetic placements of these families and family-level clades. We provide an outline of the genera and the families of Leotiomycetes and a table summarising sexual morph characters of all
\end{abstract}


the families/family-level clades of Leotiomycetes. Nine new families are introduced and we provide descriptions and illustrations of 50 Leotiomycetes taxa including six new genera and 22 new species, from collections made in China, Italy, Thailand, Russia, UK and Uzbekistan. Small scale phylogenetic analyses using concatenated datasets of five loci (rDNA, TEF and RBP2) are provided, where the backbone tree is insufficient to confirm the phylogenetic placement of our collections. This paper contributes to a more comprehensive update and improved identification of Leotiomycetes based on available literature and our collections.

Key words - 37 new taxa - Apothecial ascomycetes - Ascus amyloidity - Multi-gene analysis Monophyly

\section{Introduction}

Eriksson \& Winka (1997) introduced the class Leotiomycetes to accommodate inoperculate discomycetes. The traditional concept of Leotiomycetes includes only apothecial ascomycetes with inoperculate, unitunicate asci that open by apical perforation or pore to release their ascospores (Dennis 1968, Korf 1973, Nannfeldt 1932, Pfister \& Kimbrough 2001). Therefore, Leotiomycetes are often referred to as the "inoperculate discomycetes". Previously this class included a wide range of taxa (Korf 1973, Spooner 1987), but modern molecular-based studies have removed some groups to establish a more natural classification (Wang et al. 2006a, b, Baral et al. 2015, Pärtel 2016). This class includes 12 orders, 44 families and around 580 genera, excluding new taxa introduced here (Ekanayaka et al. 2017, Jaklitsch et al. 2016, Wijayawardene et al. 2018).

The ascomata of Leotiomycetes are diverse and mostly apothecial. However, Erysiphaceae, Myxotrichaceae, and some Thelebolaceae and Rutstroemiaceae produce cleistothecial ascomata (Blackwell et al. 2006, de Hoog et al. 2005, Gernandt et al. 2001, Reid 1986, Galán et al. 2015) and some Hyaloscyphaceae, Loramycetaceae and Thelebolales form perithecial ascomata (Ingold \& Chapman 1952, Digby \& Goos 1987, Ranzoni 1956, Jaklitsch et al. 2016). Apothecial morphology is also diverse. For example, Helotiales apothecia are cupulate and brightly coloured, mostly covered with excipular hairs; Cyttariales produce compound, globose apothecia and Triblidiales and some Rhytismatales produce hysteracious apothecia; Lahmiales, Leotiales and some Rhytismatales taxa have clavate apothecia; and Medeolariales include immersed, reduced apothecia (Spooner 1987, Korf 1973, Baral et al. 2015, Ekanayaka et al. 2017). Most Leotiomycetes produce inoperculate asci although some Thelebolales produce operculate asci (Brummelen \& Kristiansen 1998, Cain \& Kimbrough 1969, Brummelen 1977).

Leotiomycetes is an ecologically diverse group, most are saprobes of a wide variety of substrates, such as Helotiaceae, Lachnaceae and Hyaloscyphaceae on dead plant material and Thelebolales on dung or as endophytes (Wang et al. 2006a, b, Jaklitsch et al. 2016). Some, such as Medeolariales, Sclerotiniaceae, Erysiphales, some Helotiales and some Rhytismatales are important plant pathogens (Takamatsu et al. 2015, Lantz et al. 2011, Wang et al. 2006a, b). The class also includes endophytes, mycorrhizae, fungal parasites, root symbionts, and wood rot fungi (Wang et al. 2006a, b, Jaklitsch et al. 2016). Most Leotiomycetes taxa are described from the temperate Northern Hemisphere, but some members in Helotiales, and Rhytismatales show a broader geographic distribution (Ekanayaka et al. 2017, Wang et al. 2006a, b, McLaughlin \& Spatafora 2015).

Although there are many recent phylogenies on Leotiomycetes (Hustad \& Miller 2011, Johnston et al. 2014, Baral et al. 2015, Pärtel 2016, Pärtel et al. 2017), many unresolved issues remain within the class. The familial and order-level classification is phylogenetically poorly understood, especially in the order Helotiales which is highly polyphyletic (Wang et al. 2006a, b, Pärtel 2016, Jaklitsch et al. 2016). Therefore, the present study aims to clarify the taxonomic uncertainty of Leotiomycetes orders and families. By putting this data together into a single article, we provide a working document that can be criticised and improved. We therefore provide discussion on their morphology, and elaborate on their systematic arrangements. Furthermore, here we recognize several clades based on the topology in our phylogenetic analyses and they probably 
will be new families or orders in the near future. Although some clades have distinct characters, we did not observe stable phylogenetic placements for those clades in our phylogenetic analyses. Therefore, we have not introduced these taxa in the present study, but here we name them as family-level and order-level clades. With more data these clades may be resolved in the future.

\section{Material \& methods}

\section{Sample collection specimen examination and deposition}

Collections of Leotiomycetes were made in Thailand, China, UK, Italy, Russia and Uzbekistan from 2012 to 2017. Macroscopic and microscopic characters of the specimens were recorded. A Motic SMZ-168 stereo microscope was used to observe the structure of the apothecia. Sections of apothecia were made with a razor blade, mounted in water or $5 \% \mathrm{KOH}$ and preserved in lacto-glycerol on a glass slide. A Nikon ECLIPSE 80i compound microscope was used to observe microscopic characters. Photomicrography was carried out with a Canon 450D digital camera fitted to the microscope. Measurements of apothecia, paraphyses, asci and ascospores were made from material mounted in water and the mean values are used in the descriptions. Measurements were made with the Taro soft (R) Image Frame Work v. 0.9.7 program and images used for figures were processed with Adobe Photoshop CS6 software (Adobe Systems). The specimens are deposited in the Mae Fah Luang University Herbarium (MFLU), Chiang Rai, Thailand and in the Herbarium of Cryptogams of Kunming Institute of Botany, Chinese Academy of Sciences (KUN-HKAS). Faces of fungi numbers and Index Fungorum numbers were registered as described in Jayasiri et al. (2015) and Index Fungorum (2019).

\section{DNA extraction, PCR and sequencing}

Genomic DNA was extracted directly from apothecia using a Plant DNA Rapid Extraction Kit (Bio Teke Corporation, Beijing, China). Polymerase chain reactions (PCR) for this study were carried out using five gene regions: NS1 and NS4 for the nuclear ribosomal small subunit (SSU) (White et al. 1990), LROR and LR5 (Vilgalys \& Hester 1990) for the nuclear ribosomal large subunit (LSU), ITS4 and ITS5 (White et al. 1990) for internal transcribed spacer (ITS), TEF1-728F and TEF1-986R (Carbone \& Kohn 1999) for translation elongation factor 1-alpha (TEF1- $\alpha$ ) and fRPB2-5F and fRPB2-7cR (Liu et al. 1999) for RNA polymerase II (RPB2). The PCR mixtures (25 $\mu \mathrm{L})$ contained $\mathrm{ddH}_{2} \mathrm{O}(11 \mu \mathrm{L})$, PCR Master Mix (TIANGEN Co., China) $(11 \mu \mathrm{L} ; 2 \times)$, DNA template $(1 \mu \mathrm{L})$, each primer $(1 \mu \mathrm{L} ; 10 \mu \mathrm{M})$. PCR amplification conditions for all regions consisted an initial denaturation step of $5 \mathrm{~min}$ at $94{ }^{\circ} \mathrm{C}, 35$ cycles consisted of denaturation at $94{ }^{\circ} \mathrm{C}$ for 1 minute, annealing at $53{ }^{\circ} \mathrm{C}$ for 50 seconds and elongation at $72{ }^{\circ} \mathrm{C}$ for 3 minutes and final extension step of 7 minutes at $72{ }^{\circ} \mathrm{C}$. The PCR products were viewed on $2 \%$ agarose electrophoresis gels, stained with Ethidium bromide. PCR products were sent to a commercial sequencing provider (Tao Yang, Beijing, China).

\section{Sequence alignment and phylogenetic analysis}

Newly generated sequences were subjected to a standard BLAST search of GenBank for primary identification and the newly generated sequences are deposited in GenBank (Supplementary Table 1).

\section{Back-bone tree for Leotiomycetes}

Sequence data from five loci (ITS, LSU, SSU, RPB2 and TEF) of 482 strains belonging to representative Leotiomycetes species along with the out-group taxa Ophiocordyceps irangiensis (OSC 128578) and Cryptosporella hypodermia (AFTOL ID 2124), were downloaded from GenBank (Supplementary Table 1). For each gene, the newly generated sequences and representatives from GenBank were aligned using MAFFT $v .7$ (http://mafft.cbrc.jp/alignment/server/index.html) (Katoh et al. 2017) and manually adjusted in BioEdit v. 7.0.4 (Hall 2004) where necessary. The individual datasets were concatenated into a 
combined dataset using FaBox (1.41) (Villesen 2007). Ambiguously aligned regions were excluded and gaps were treated as missing data.

GTR+ G +I substitution model was selected as the model of evolution, based on the results from MrModeltest 2.2 (Nylander 2004). Maximum likelihood phylogenetic analyses were performed in CIPRES webportal (Miller et al. 2010) using RAxML-HPC2 Workflow on XSEDE (8.2.9) tool (Stamatakis 2014). The bootstrap analysis for each ML tree was performed with 1000 thorough bootstrap replicates with the same parameter settings. Posterior probabilities (PP) (Rannala \& Yang 1996; Zhaxybayeva \& Gogarten 2002) were determined by Markov chain Monte Carlo sampling (MCMC) in CIPRES webportal (Miller et al. 2010) using MrBayes on XSEDE (Huelsenbeck \& Ronquist 2000). Four simultaneous Markov chains were run for 50, 000, 000 generations and trees were sampled every $1000^{\text {th }}$ generation. The MCMC heated chain was set with a "temperature" value of 0.2 . The distribution of loglikelihood scores was examined to determine stationary phase for each search and to decide if extra runs were required to achieve convergence, using the program Tracer 1.5 (Rambaut \& Drummond 2009). All sampled topologies beneath the asymptote $(38 \%)$ were discarded as part of a burn-in procedure, while the remaining trees were used for calculating posterior probabilities in the majority rule consensus tree.

$\underline{\text { Sub-trees for new Leotiomycetes collections during the study }}$

Sequences from GenBank were downloaded according to their relevance. Sequence alignments, combined dataset preparation and maximum likelihood phylogenetic analyses were performed as described above.

The resulting trees were viewed with FigTree v.1.4.0 (Rambaut 2006, 2009, http://tree.bio.ed.ac.uk/software/figtree/). Maximum likelihood bootstrap values (MLBP) equal or greater than $50 \%$ and Bayesian posterior probabilities (BYPP) values equal or greater than 0.9 are given above the nodes.

\section{Phylogeny}

The phylogenetic relationships of Leotiomycetes were investigated based on analysis of LSU, SSU, ITS, TEF and RPB2 sequence data. The combined alignment of 482 taxa included 4575bp (LSU-1-573, SSU-574-1464, ITS-1465-2502, TEF-2503-3613, RPB2-3614-4575). The best scoring RAxML tree with a final likelihood value of -181075.223865 is presented (Fig. 1). The matrix had 3686 distinct alignment patterns, with $60.88 \%$ of undetermined characters or gaps. Estimated base frequencies were as follows; $\mathrm{A}=0.252, \mathrm{C}=0.228, \mathrm{G}=0.269, \mathrm{~T}=0.251$; substitution rates $\mathrm{AC}=$ 1.501780, $\mathrm{AG}=2.986334, \mathrm{AT}=1.409516, \mathrm{CG}=0.891646, \mathrm{CT}=6.126022, \mathrm{GT}=1.000000$; gamma distribution shape parameter $\alpha=0.432398$. Compressed overview of the phylogram generated from maximum likelihood analysis of combined LSU, SSU, ITS, TEF and RPB2 sequence data for taxa of Leotiomycetes families is also provided (Fig. 2). Seventeen sub-trees to represent the exact phylogenetic placement of our new Leotiomycetes collections are also included within this section.

According to the phylogenetic tree for Leotiomycetes, we identified 19 clades, which can be recognized as orders/order-level clades. The phylogenetic placements of these clades are briefly discussed below.

\section{Clade 1:}

\section{LAURIOMYCETALES: Lauriomycetaceae}

This is the most basal clade of Leotiomycetes and includes the single family Lauriomycetaceae. Its basal position was also noted by Hernandez-Restrepo et al. (2017).

\section{Clade 2:}

\section{CHAETOMELLALES: Chaetomellaceae, Marthamycetaceae}

The families Chaetomellaceae and Marthamycetaceae formed a monophyletic clade, which can be recognized as the order Chaetomellales. Pärtel (2016) showed the close phylogenetic 
relationship of Chaetomellaceae and Marthamycetaceae. Although, both of these families formed well supported monophyletic clades within our phylogenetic analysis, their sister relationship is not statistically well-supported.

\section{Clade 3:}

Trizodia-Calloriopsis clade: Trizodia clade, Corticifraga clade

This clade includes the genera Trizodia, Spirosphaeria, Calloriopsis and Corticifraga.

\section{Clade 4:}

\section{"HELICOGONIALES": Helicogoniaceae}

Previously the family Helicogoniaceae was classified in order Phacidiales but in our study it forms an independent clade.

\section{Clade 5:}

\section{PHACIDIALES: Phacidiaceae}

The family Phacidiaceae formed a monophyletic clade close to "Helicogoniales" clade. Previously, this order included three families: Helicogoniaceae, Phacidiaceae and Tympanidaceae. According to our phylogenetic analysis these three families do not form monophyletic clades. Johnston et al. (2014) and Pärtel (2016) also showed the polyphyly of these families based on their phylogenetic analyses.

\section{Clade 6:}

\section{Micraspis clade}

Micraspis acicula, which was formerly placed under Tympanidaceae, formed a separate clade close to Phacidiaceae.

\section{Clade 7:}

\section{Flagellospora clade}

Flagellospora curvula formed a close phylogenetic affinity to Leotiales.

\section{Clade 8:}

LEOTIALES: Cochlearomycetaceae, Gelatinomyces clade, Leotiaceae, Tympanidaceae

This clade includes the families Cochlearomycetaceae, Gelatinomyces, Leotiaceae and Tympanidaceae. Pärtel (2016) also showed the close phylogenetic relationship of Leotiaceae and Tympanidaceae based on a five gene phylogeny.

\section{Clade 9:}

LICHINODIALES: Epithamnolia-Epicladonia clade, Lichinodiaceae

This clade includes Epithamnolia-Epicladonia clade and Lichinodiaceae.

\section{Clade 10:}

\section{THELEBOLALES: Thelebolaceae, Alatospora- Miniancora clade}

This clade includes the family Thelebolaceae and Alatospora-Miniancora clade. It forms a monophyletic clade that is sister to Lichinodiales. A similar phylogenetic placement, based on a five gene analysis was recorded by Pärtel (2016).

\section{Clade 11:}

\section{Neocrinulaceae}

This family formed an unstable affiliation closer to Leptodontidiaceae, but this phylogenetic association is not statistically supported.

Clade 12:

Leptodontidiaceae 
Leptodontidiaceae nested between Neocrinulaceae and Rhytismatales clades. This is moderately supported in our phylogenetic analysis.

\section{Clade 13:}

RHYTISMATALES: Calloriaceae, Pezizellaceae, Rhytismataceae

This clade includes the families Rhytismataceae, Pezizellaceae, Calloriaceae.

\section{Clade 14:}

Hamatocanthoscypha-Hyphodiscus clade: Hyphodiscaceae, Hamatocanthoscyphaceae

This clade includes two sub-clades, which includes the genera formerly belonging to Helotiales.

\section{Clade 15:}

MEDEOLARIALES: Ascocorticiaceae, Ascodichaenaceae, Dermateaceae, ColeophomaParafabraea clade, Medeolariaceae

The families Medeolariaceae, Ascodichaenaceae, Dermateaceae and ColeophomaParafabraea grouped in a clade that sister to "Sclerotiniales". Individually these familial clades are not well-supported. Members in Ascocorticiaceae do not have available sequence data in GenBank for DNA based comparisons. However, this group of species show similar morphology to Medeolariales taxa and therefore, we place this family under Medeolariales.

\section{Clade 16:}

"SCLEROTINIALES": Cenangiaceae, Chlorociboriaceae, Hemiphacidiaceae, Neolauriomycetaceae, Rutstroemiaceae and Sclerotiniaceae

This clade includes the families Sclerotiniaceae, Hemiphacidiaceae, Cenangiaceae, Rutstroemiaceae and Chlorociboriaceae, which were previously classified under Helotiales. In our phylogenetic analysis, these families formed a monophyletic clade close to Medeolariales. Pärtel (2016) also suggested that Sclerotiniaceae, Hemiphacidiaceae, Cenangiaceae and Rutstroemiaceae, form a monophyletic group separate from other Helotiales and named this clade as "Sclerotiniales". Our results agree with those of Pärtel (2016).

\section{Clade 17:}

CYTTARIALES: Cordieritidaceae, Cyttariaceae, Deltopyxidaceae

The families Cordieritidaceae, Cyttariaceae and Deltopyxidaceae formed a monophyletic clade sister to Erysiphales.

\section{Clade 18:}

\section{ERYSIPHALES: Erysiphaceae, Amorphothecaceae}

The family Erysiphaceae and Amorphothecaceae formed a monophyletic clade sister to Cyttariales.

\section{Clade 19:}

HELOTIALES: Amicodiscaceae, Aquapoterium-Unguicularia clade, Arachnopezizaceae, Bryoglossaceae, Bulgariella clade, Chlorospleniaceae, Colipila clade, Discinellaceae, Drepanopezizaceae, Gelatinodiscaceae, Godroniaceae, Helotiaceae, Heterosphaeriaceae, Hyaloscyphaceae, Hydrocinaceae, Lachnaceae, Loramycetaceae, Mitrulaceae, Mollisiaceae, Patellariopsis clade, Ploettnerulaceae, Phialocephala urceolata clade, Peltigeromyces clade, Solenopeziaceae, Vibrisseaceae

This clade includes 25 families/family-level clades, which are classified under Helotiales. 


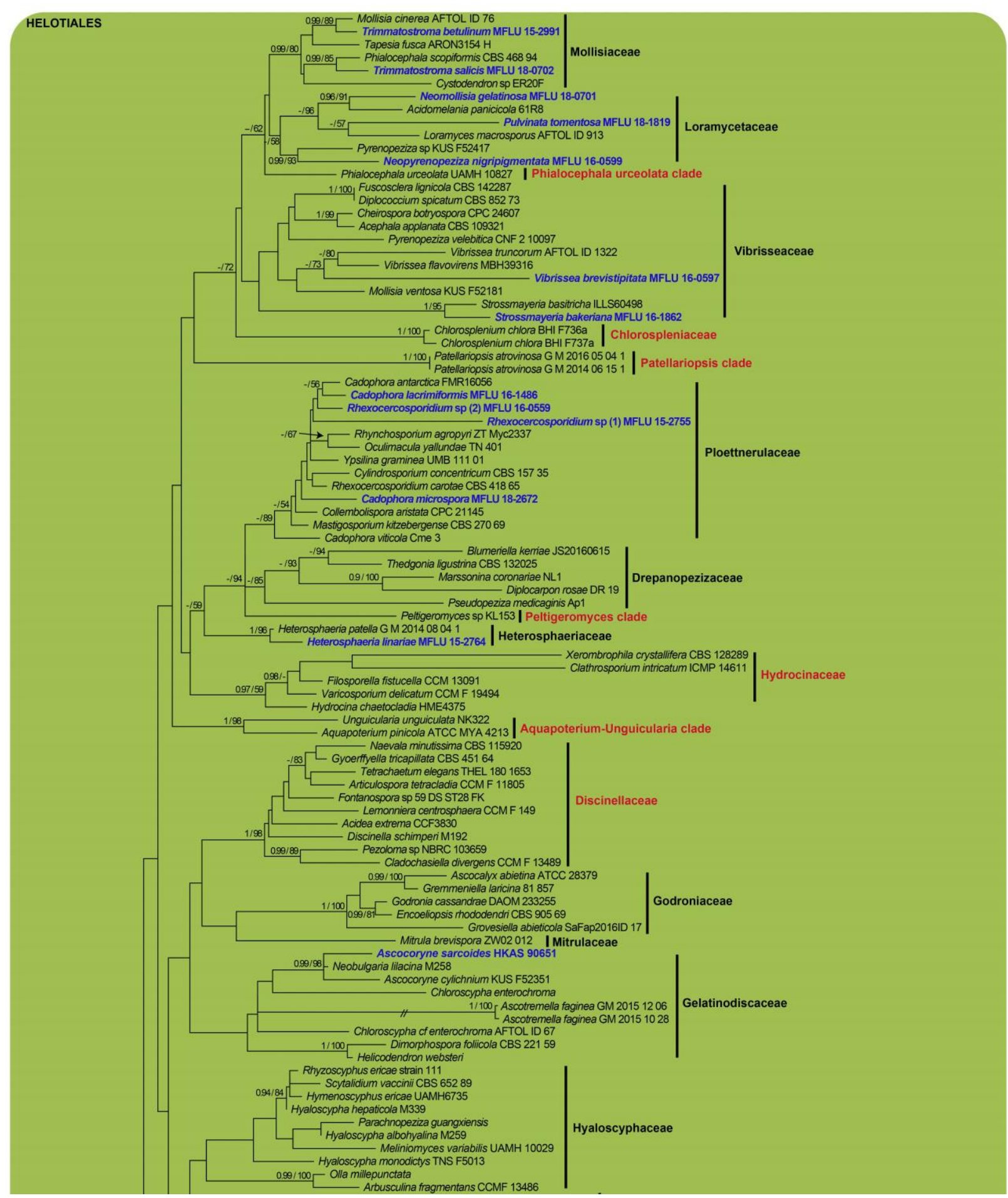

Figure 1 - Maximum likelihood phylogenetic tree inferred from 482 taxa of Leotiomycetes based on combined LSU, SSU, ITS, TEF and RPB2 sequence data. MLBP values $\geq 50 \%$ are given as the first set of numbers and BYPP $\geq 0.90$ values as the second set of numbers above the nodes. Strain/culture numbers are given after the taxon names. The tree is rooted with Ophiocordyceps irangiensis (OSC 128578) and Cryptosporella hypodermia (AFTOL ID 2124). Orders/order-level clades are named in left and families/family-level clades are named in rignt. Newly generated sequences are in blue bold and new families/family-level clades and orders/order-level clades are in red. 


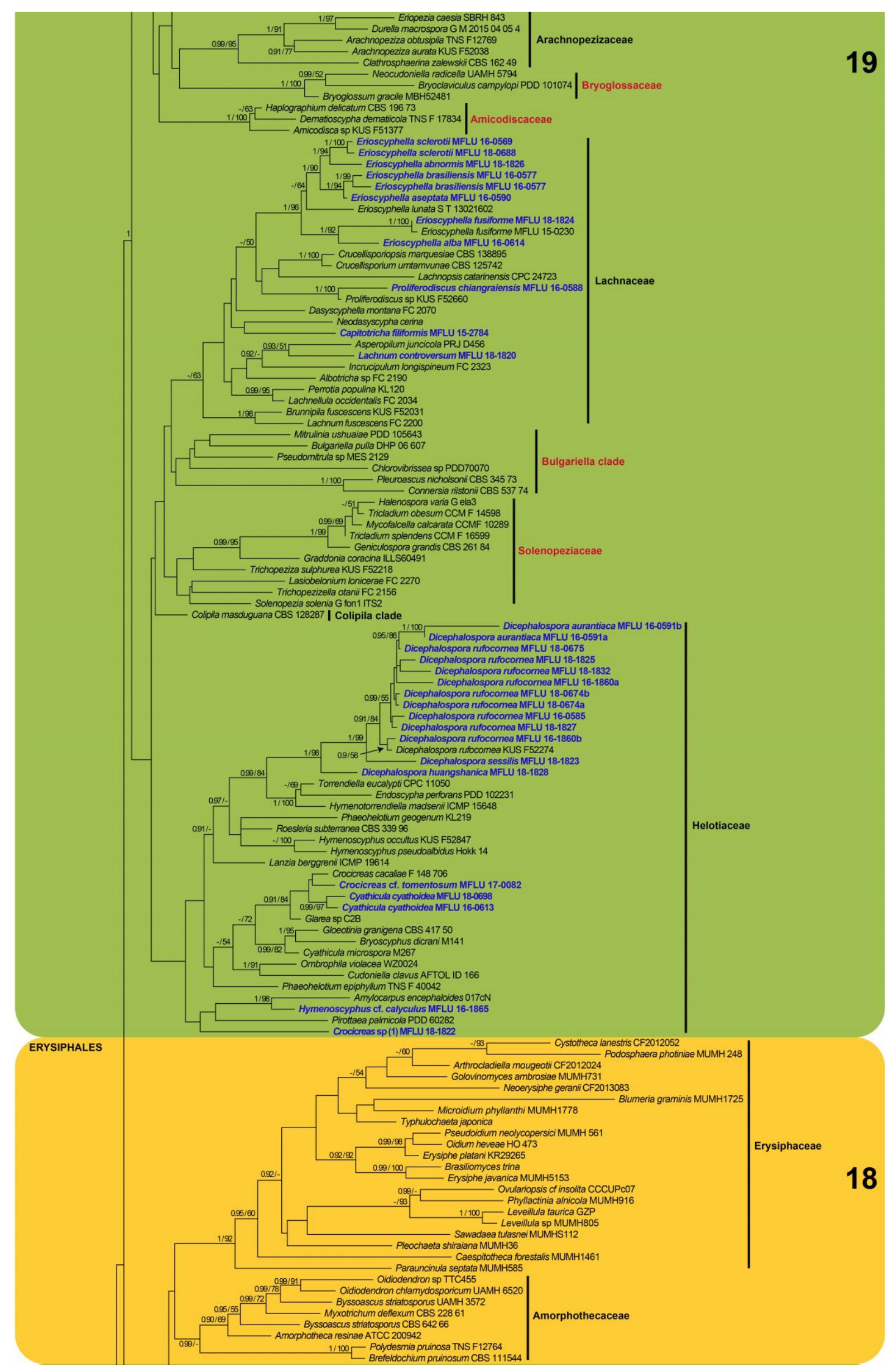

Figure 1 - Continued. 


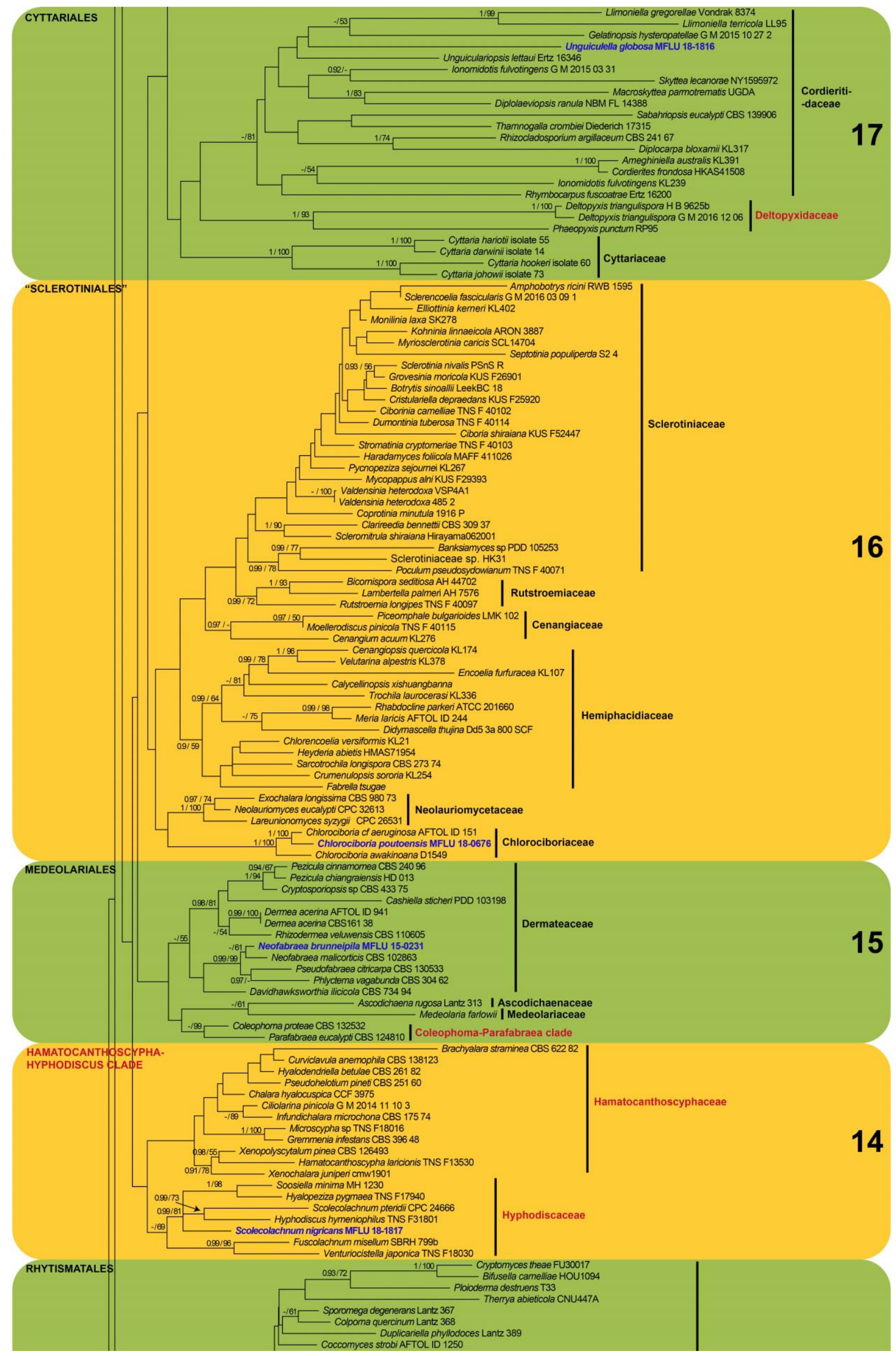

Figure 1 - Continued. 


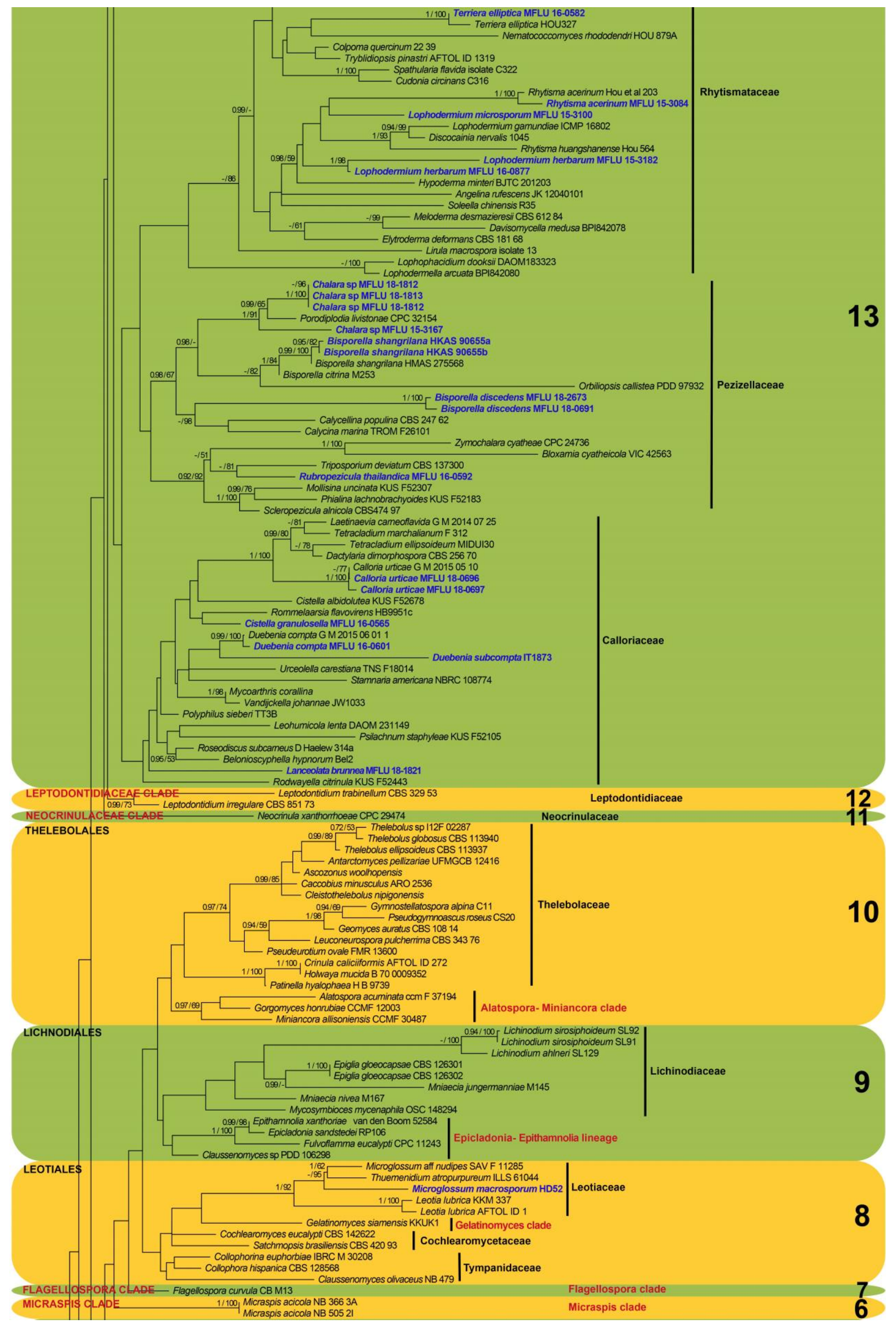

Figure 1 - Continued. 


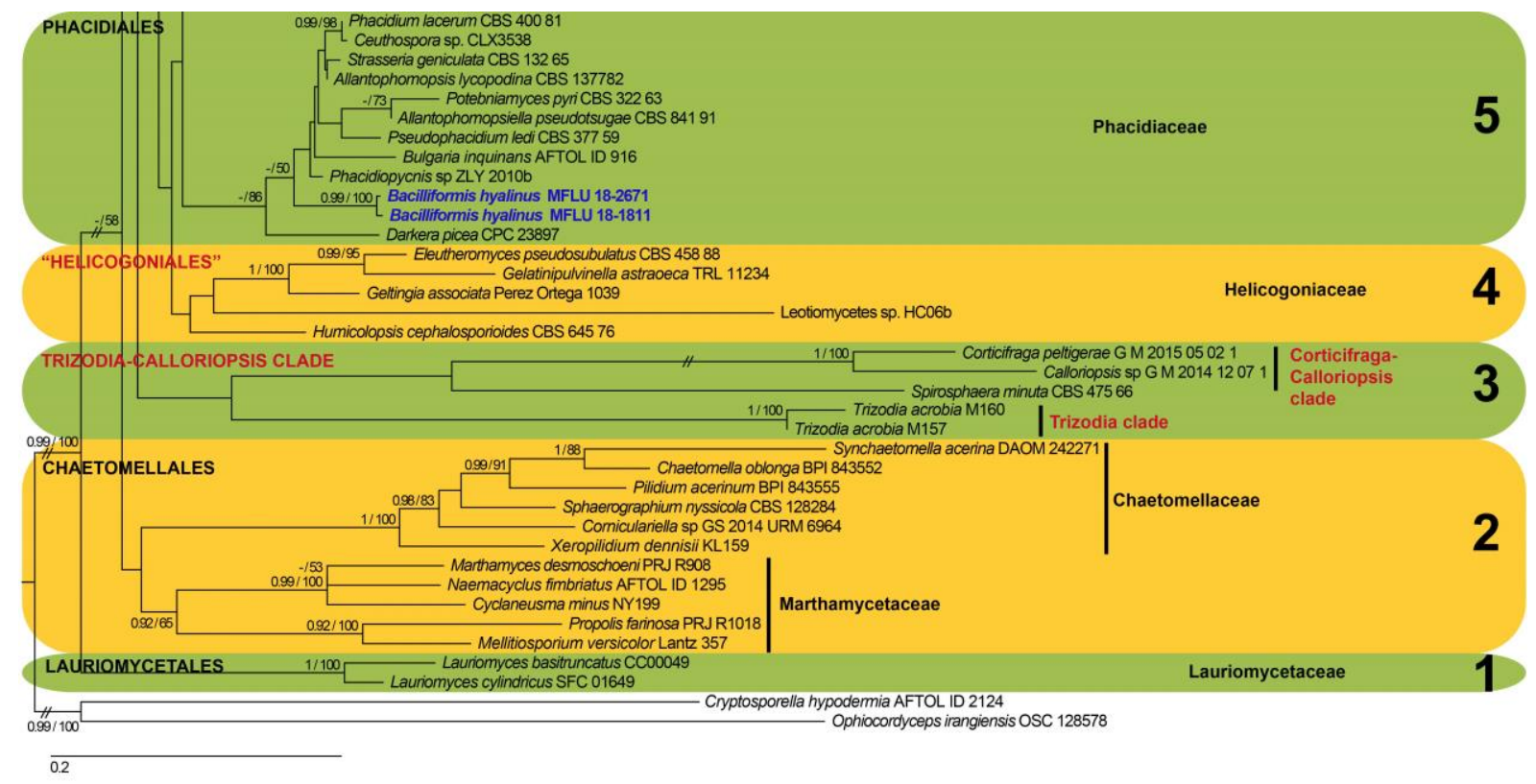

Figure 1 - Continued.

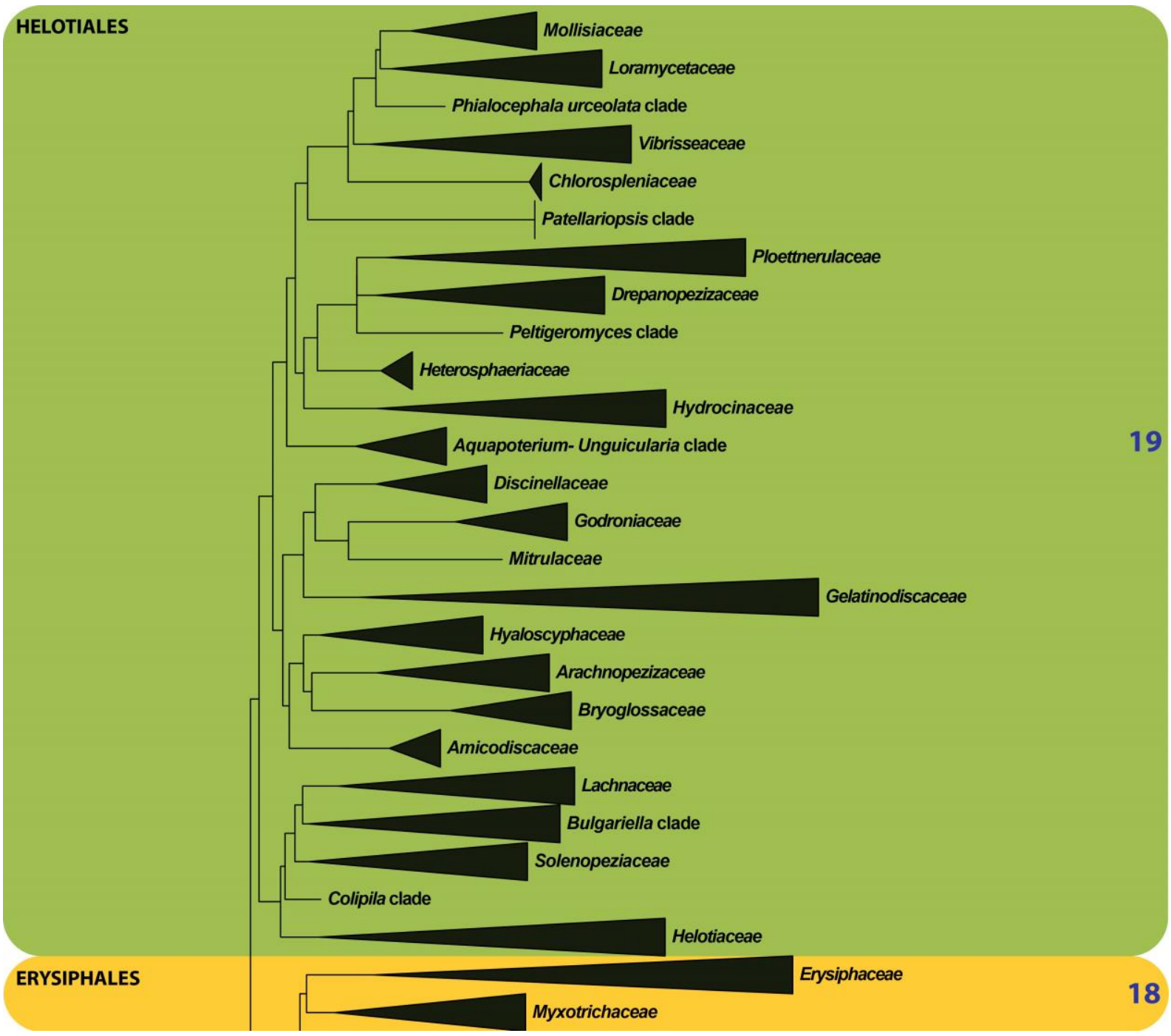

Figure 2 - Compressed overview of the phylogram generated from maximum likelihood analysis of combined LSU, SSU, ITS, TEF and RPB2 sequence data for taxa of Leotiomycetes. 


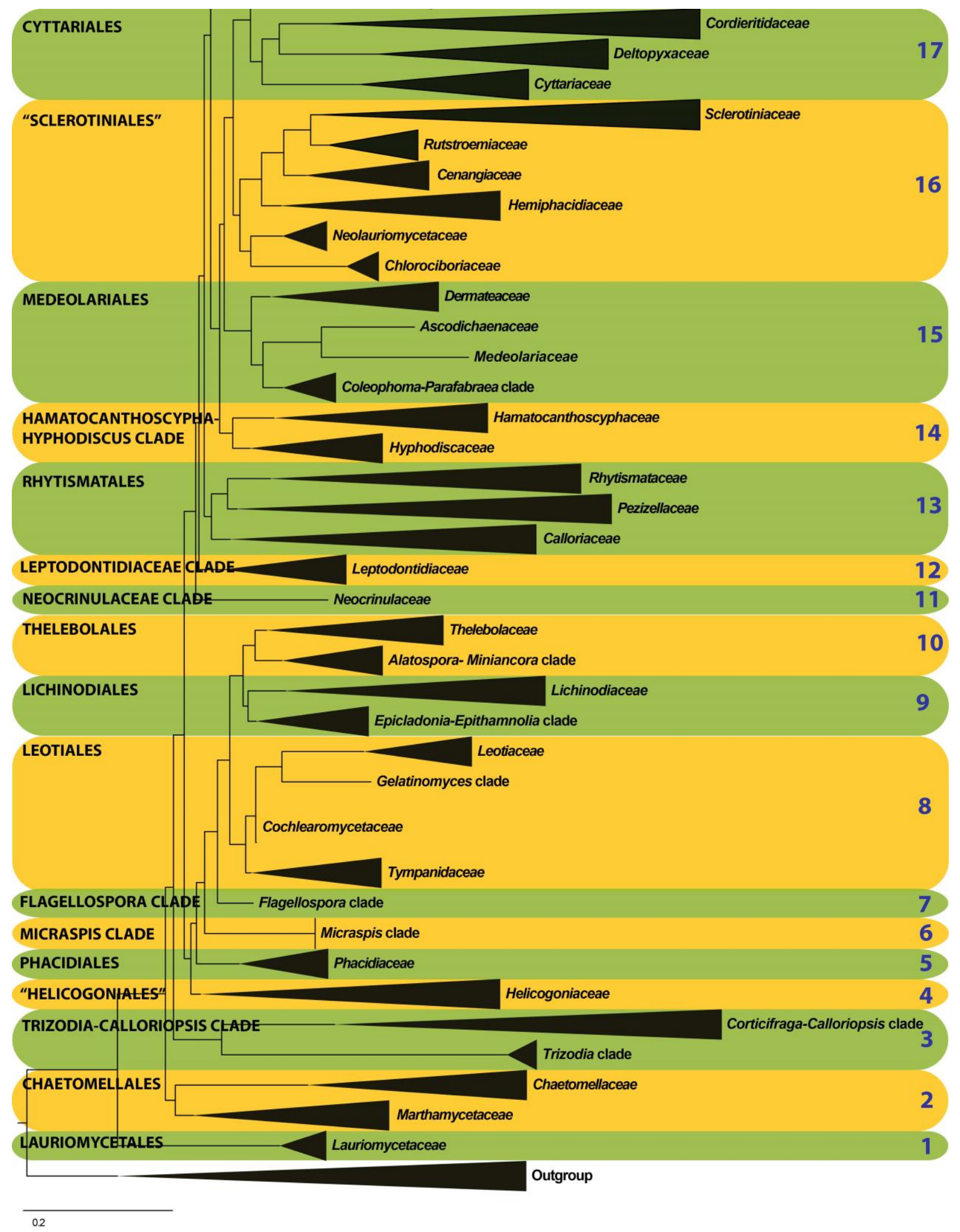

Figure 2 - Continued.

\section{Taxonomy}

Various arrangements for the class Leotiomycetes have been developed, first based on morphology (e.g. Nannfeldt 1932, Korf 1973, Hawksworth et al. 1983 and Spooner 1987) and more recently using phylogenetic evidence (e.g. Baral et al. 2015, Johnston et al. 2014, Pärtel et al. 2017, Hustad \& Miller 2011). The most recent arrangement of Leotiomycetes includes the classification of Wijayawardene et al. (2018) and is followed here, with modifications. 
Table 1 The outline of genera within Leotiomycetes

\begin{tabular}{|c|c|c|}
\hline $\begin{array}{l}\text { Order/Order-level } \\
\text { clade }\end{array}$ & Family/Family-level clade & Genera \\
\hline \multirow[t]{2}{*}{ Chaetomellales } & Chaetomellaceae & $\begin{array}{l}\text { Chaetomella, Corniculariella, Hainesia, Pilidium, Sphaerographium, Synchaetomella, } \\
\text { Xeropilidium }\end{array}$ \\
\hline & Marthamycetaceae & $\begin{array}{l}\text { Cyclaneusma, Marthamyces, Mellitiosporiella, Mellitiosporium, Naemacyclus, } \\
\text { Phragmiticola, Propolina, Propolis }\end{array}$ \\
\hline \multirow[t]{3}{*}{ Cyttariales } & Cyttariaceae & Cyttaria \\
\hline & Cordieritidaceae & $\begin{array}{l}\text { Ameghiniella, Austrocenangium, Cordierites, Diplocarpa, Diplolaeviopsis, Gelatinopsis, } \\
\text { Hamalocanlhoscypha, Ionomidotis, Llimoniella, Midotiopsis, Macroskyttea, Phaeangella, } \\
\text { Rhymbocarpus, Rhizocladosporium, Skyttea, Skyttella, Sabahriopsis, Thamnogalla, } \\
\text { Unguiculariopsis, Unguiculella }\end{array}$ \\
\hline & Deltopyxidaceae & Deltopyxis, Phaeopyxis \\
\hline \multirow[t]{2}{*}{ Erysiphales } & Amorphothecaceae & Amorphotheca, Brefeldochium, Byssoascus, Myxotrichum, Oidiodendron, Polydesmia \\
\hline & Erysiphaceae & $\begin{array}{l}\text { Arthrocladiella, Blumeria, Brasiliomyces, Caespitotheca, Cystotheca, Erysiphe, } \\
\text { Golovinomyces, Leveillula, Microidium, Neoerysiphe, Oidiopsis, Oidium, Ovulariopsis, } \\
\text { Parauncinula, Pseudoidium, Phyllactinia, Pleochaeta, Podosphaera, Queirozia, } \\
\text { Sawadaea, Takamatsuella, Typhulochaeta }\end{array}$ \\
\hline Flagellospora clade & Flagellospora clade & Flagellospora \\
\hline "Helicogoniales" & Helicogoniaceae & $\begin{array}{l}\text { Eleutheromycella, Eleutheromyces, Gelatinipulvinella, Geltingia, Helicogonium, } \\
\text { Humicolopsis }\end{array}$ \\
\hline \multirow[t]{2}{*}{$\begin{array}{l}\text { Hamatocanthoscypha- } \\
\text { Hyphodiscus clade }\end{array}$} & Hamatocanthoscyphaceae & $\begin{array}{l}\text { Brachyalara, Chalara, Ciliolarina, Curviclavula, Gremmenia, Hamatocanthoscypha, } \\
\text { Hyalodendriella, Infundichalara, Microscypha, Pseudohelotium, Xenochalara, } \\
\text { Xenopolyscytalum, }\end{array}$ \\
\hline & Hyphodiscaceae & Fuscolachnum, Hyalopeziza, Hyphodiscus, Soosiella, Scolecolachnum, Venturiocistella \\
\hline \multirow[t]{8}{*}{ Helotiales } & Arachnopezizaceae & Arachnopeziza, Arachnoscypha, Austropezia, Eriopezia, Durella \\
\hline & Amicodiscaceae & Amicodisca, Dematioscypha, Haplographium \\
\hline & Aquapoterium- Unguicularia clade & Aquapoterium, Unguicularia \\
\hline & Bryoglossaceae & Bryoclaviculus, Bryoglossum, Neocudoniella \\
\hline & Bulgariella clade & Pleuroascus, Connersia, Chlorovibrissea, Pseudomitrula, Mitrulinia, Bulgariella \\
\hline & Chlorospleniaceae & Chlorosplenium \\
\hline & Colipila clade & Colipila \\
\hline & Discinellaceae & $\begin{array}{l}\text { Articulospora, Acidea, Cladochasiella, Discinella, Fontanospora, Gyoerffyella, } \\
\text { Lemonniera, Naevala, Pezoloma, Tetrachaetum }\end{array}$ \\
\hline
\end{tabular}


Table 1 Continued.

\begin{tabular}{|c|c|c|}
\hline $\begin{array}{l}\text { Order/Order-level } \\
\text { clade }\end{array}$ & Family/Family-level clade & Genera \\
\hline \multirow[t]{15}{*}{ Helotiales } & Drepanopezizaceae & $\begin{array}{l}\text { Blumeriella, Diplocarpon, Drepanopeziza, Felisbertia, Leptotrochila, Marssonina, } \\
\text { Pseudopezicula, Spilopodiella, Spilopodia, Thedgonia }\end{array}$ \\
\hline & Gelatinodiscaceae & $\begin{array}{l}\text { Ascotremella, Ascocoryne, Chloroscypha, Didymocoryne, Neobulgaria, Phaeangellina, } \\
\text { Skyathea, Dimorphospora, Helicodendron }\end{array}$ \\
\hline & Godroniaceae & Ascocalyx, Atropellis, Godronia, Gremmeniella, Grovesiella \\
\hline & Helotiaceae & $\begin{array}{l}\text { Amylocarpus, Ascoconidium, Asterocalyx, Bryoscyphus, Chaetoscypha, Crocicreas, } \\
\text { Cudoniella, Cyathicula, Dicephalospora, Endoscypha, Glarea, Helicocentralis, } \\
\text { Hymenoscyphus, Hymenotorrendiella, Lanzia, Muscicola, Mytilodiscus, Ombrophila, } \\
\text { Phaeohelotium, Pirottaea, Pithyella, Pseudoniptera, Roesleria, Roeslerina, Symphyosirinia, } \\
\text { Tatraea, Torrendiella, Discorehmia, Eubelonis, Calycella, Gloeotinia, Xylogramma }\end{array}$ \\
\hline & Heterosphaeriaceae & Heterosphaeria \\
\hline & Hyaloscyphaceae & $\begin{array}{l}\text { Ambrodiscus, Aeruginoscyphus, Dimorphotricha, Echinula, Glutinomyces, Graddonidiscus, } \\
\text { Grahamiella, Hegermila, Hyaloscypha, Incrupila, Meliniomyces, Olla, Polaroscyphus, } \\
\text { Proprioscypha, Protounguicularia, Psilocistella, Parachnopeziza, Rhyzoscyphus, } \\
\text { Scytalidium, Thindiomyces, Unguiculariella, Mycoarthris, Hyphopeziza, Curviclavula, } \\
\text { Crucellisporiopsis, Clathrosphaerina, Arbusculina, Hyalodendriella }\end{array}$ \\
\hline & Hydrocinaceae & Filosporella, Hydrocina, Varicosporium, Xerombrophila, Clathrosporium \\
\hline & Lachnaceae & $\begin{array}{l}\text { Albotricha, Asperopilum, Belonidium, Brunnipila, Capitotricha, Crucellisporiopsis, } \\
\text { Crucellisporium, Dasyscyphella, Erioscyphella, Incrucipulum, Lachnellula, Lachnum, } \\
\text { Lachnopsis, Neodasyscypha, Perrotia, Proliferodiscus, Tubolachnum }\end{array}$ \\
\hline & Loramycetaceae & Acidomelania, Loramyces, Obtectodiscus \\
\hline & Mitrulaceae & Mitrula \\
\hline & Mollisiaceae & $\begin{array}{l}\text { Bulbomollisia, Cystodendron, Discocurtisia, Mollisia, Neotapesia, Niptera, Nipterella, } \\
\text { Phialocephala, Pseudonaevia, Pyrenopeziza, Sarconiptera, Scutobelonium, Scutomollisia, } \\
\text { Trimmatostroma, Tapesia, Variocladium }\end{array}$ \\
\hline & Patellariopsis clade & Patellariopsis \\
\hline & Peltigeromyces clade & Peltigeromyces \\
\hline & Phialocephala urceolata clade & Phialocephala \\
\hline & Ploettnerulaceae & $\begin{array}{l}\text { Cylindrosporium, Cadophora, Collembolispora, Dennisiodiscus, Lasiomollisia, } \\
\text { Mastigosporium, Mycochaetophora, Nothophacidium, Oculimacula, Ploettnerula, } \\
\text { Pseudopeziza, Peltigeromyces, Rhynchosporium, Rhexocercosporidium, Ypsilina }\end{array}$ \\
\hline
\end{tabular}


Table 1 Continued.

\begin{tabular}{|c|c|c|}
\hline $\begin{array}{l}\text { Order/Order-level } \\
\text { clade }\end{array}$ & Family/Family-level clade & Genera \\
\hline \multirow[t]{2}{*}{ Helotiales } & Solenopeziaceae & $\begin{array}{l}\text { Geniculospora Tricladium, Graddonia, Mycofalcella, Halenospora, Trichopeziza, } \\
\text { Lasiobelonium, Trichopezizella, Solenopezia }\end{array}$ \\
\hline & Vibrisseaceae & $\begin{array}{l}\text { Acephala, Cheirospora, Diplococcium, Fuscosclera, Gorgoniceps, Leucovibrissea, } \\
\text { Pocillum, Strossmayeria, Vibrissea }\end{array}$ \\
\hline Lahmiales & Lahmiaceae & Lahmia \\
\hline Leptodontidiaceae clade & Leptodontidiaceae & Leptodontidium \\
\hline Lauriomycetales & Lauriomycetaceae & Lauriomyces \\
\hline \multirow[t]{4}{*}{ Leotiales } & Cochlearomycetaceae & Cochlearomyces, Satchmopsis \\
\hline & Gelatinomyces clade & Gelatinomyces \\
\hline & Leotiaceae & Geocoryne, Leotia, Microglossum, Thuemenidium \\
\hline & Tympanidaceae & $\begin{array}{l}\text { Aotearoamyces, Claussenomyces, Collophora, Collophorina, Durandiella, } \\
\text { Gelatinosporium, Myriodiscus, Pragmopora, Tympanis }\end{array}$ \\
\hline Lichinodiales & $\begin{array}{l}\text { Lichinodiaceae } \\
\text { Epicladonia-Epithamnolia clade }\end{array}$ & $\begin{array}{l}\text { Mniaecia, Mycosymbioces, Epiglia, Lichinodium } \\
\text { Epicladonia, Epithamnolia, Fulvoflamma }\end{array}$ \\
\hline \multirow[t]{5}{*}{ Medeolariales } & Ascocorticiaceae & Ascocorticium, Ascocorticiellum, Ascosorus \\
\hline & Ascodichaenaceae & Ascodichaena, Delpinoina \\
\hline & Coleophoma-Parafabraea clade & Coleophoma, Parafabraea \\
\hline & Dermateaceae & $\begin{array}{l}\text { Cashiella, Dermea, Neofabraea, Pezicula, Pseudofabraea, Phlyctema, Rhizodermea, } \\
\text { Verkleyomyces, Schizothyrioma, Davidhawksworthia }\end{array}$ \\
\hline & Medeolariaceae & Medeolaria \\
\hline Micraspis clade & Micraspis clade & Micraspis \\
\hline Neocrinulaceae clade & Neocrinulaceae & Neocrinula \\
\hline Phacidiales & Phacidiaceae & $\begin{array}{l}\text { Allantophomopsiella, Allantophomopsis, Bulgaria, Ceuthospora, Darkera, Phacidium, } \\
\text { Phacidiopycnis, Potebniamyces, Pseudophacidium, Starbaeckia, Strasseria }\end{array}$ \\
\hline \multirow[t]{2}{*}{ Rhytismatales } & Calloriaceae & $\begin{array}{l}\text { Aivenia, Belonioscyphella, Calloria, Chaetonaevia, Cistella, Dactylaria, Diplonaevia, } \\
\text { Duebenia, Eupropolella, Hyalacrotes, Iridinea, Laetinaevia, Leohumicola, Loricella, } \\
\text { Micropodia, Mycoarthris, Naeviella, Naeviopsis, Ploettnera, Polyphilus, Psilachnum, } \\
\text { Stamnaria, Rodwayella, Roseodiscus, Rommelaarsia, Tetracladium, Urceolella, } \\
\text { Vandijckella }\end{array}$ \\
\hline & Pezizellaceae & $\begin{array}{l}\text { Allophylaria, Antinoa, Bisporella, Bloxamia, Calycellina, Calycina, Micropeziza, } \\
\text { Mollisina, Mollisinopsis, Moserella, Orbiliopsis, Phaeoscypha, Phialina, Poculinia, } \\
\text { Porodiplodia, Scleropezicula, Triposporium, Velutaria, Xiambola, Zymochalara }\end{array}$ \\
\hline
\end{tabular}


Table 1 Continued.

\begin{tabular}{|c|c|c|}
\hline $\begin{array}{l}\text { Order/Order-level } \\
\text { clade }\end{array}$ & Family/Family-level clade & Genera \\
\hline Rhytismatales & Rhytismataceae & $\begin{array}{l}\text { Angelina, Apiodiscus, Bifusella, Bifusepta, Bivallium, Bonanseja, Canavirgella, Cavaraella, } \\
\text { Ceratophacidium, Cerion, Coccomyces, Colpoma, Criella, Cryptomyces, Cudonia, } \\
\text { Davisomycella, Didymascus, Discocainia, Duplicaria, Duplicariella, Elytroderma, } \\
\text { Gelineostroma, Haplophyse, Heufleria, Hypoderma, Hypodermella, Hypodermellina, Hypohelion, } \\
\text { Irydyonia, Isthmiella, Laquearia, Lasiostictella, Lirula, Lobularia, Lophodermella, } \\
\text { Lophodermium, Lophophacidium, Macroderma, Meloderma, Moutoniella, Mycomelanea, } \\
\text { Myriophacidium, Nematococcomyces, Neococcomyces, Neophacidium, Nothorhytisma, } \\
\text { Nymanomyces, Parvacoccum, Phaeophacidium, Ploioderma, Propolidium, Pseudorhytisma, } \\
\text { Pseudotrochila, Pureke, Rhytisma, Soleella, Spathularia, Sporomega, Terriera, Therrya, } \\
\text { Triblidiopsis, Tridens, Virgella, Vladracula, Xyloschizon, Zeus }\end{array}$ \\
\hline \multirow[t]{6}{*}{ "Sclerotiniales" } & Cenangiaceae & Cenangium, Moellerodiscus, Piceomphale \\
\hline & Chlorociboriaceae & Chlorociboria \\
\hline & Hemiphacidiaceae & $\begin{array}{l}\text { Cenangiopsis, Calycellinopsis, Chlorencoelia, Crumenulopsis, Didymascella, Encoelia, Fabrella, } \\
\text { Heyderia, Hysterostegiella, Korfia, Meria, Rhabdocline, Sarcotrochila, Trochila, Velutarina }\end{array}$ \\
\hline & Neolauriomycetaceae & Exochalara, Neolauriomyces, Lareunionomyces \\
\hline & Rutstroemiaceae & Bicornispora, Dencoeliopsis, Lambertella, Rutstroemia, Neometulocladosporiella \\
\hline & Sclerotiniaceae & $\begin{array}{l}\text { Amphobotrys, Botrytis, Banksiamyces, Ciboria, Ciborinia, Clarireedia, Coprotinia, Cudoniopsis, } \\
\text { Cristulariella, Dumontinia, Elliottinia, Grovesinia, Haradamyces, Kohninia, Martininia, } \\
\text { Monilinia, Mycopappus, Myrioconium, Myriosclerotinia, Ovulinia, Phaeosclerotinia, Poculum, } \\
\text { Pseudociboria, Pycnopeziza, Redheadia, Scleromitrula, Sclerencoelia, Sclerotinia, Seaverinia, } \\
\text { Septotinia, Streptotinia, Stromatinia, Valdensia, Valdensinia }\end{array}$ \\
\hline \multirow[t]{2}{*}{ Thelebolales } & $\begin{array}{l}\text { Alatospora- Miniancora } \\
\text { clade }\end{array}$ & Alatospora, Gorgomyces, Miniancora \\
\hline & Thelebolaceae & $\begin{array}{l}\text { Antarctomyces, Alatospora, Ascozonus, Ascophanus, Caccobius, Cleistothelebolus, Coprobolus, } \\
\text { Crinula, Geomyces, Gorgomyces, Gymnostellatospora, Holwaya, Leptokalpion, Leuconeurospora, } \\
\text { Miniancora, Neelakesa, Patinella, Pseudascozonus, Pseudeurotium, Pseudogymnoascus, Ramgea, } \\
\text { Thelebolus }\end{array}$ \\
\hline \multirow{2}{*}{$\begin{array}{l}\text { Trizodia-Calloriopsis } \\
\text { clade }\end{array}$} & Trizodia clade & Trizodia \\
\hline & $\begin{array}{l}\text { Corticifraga-Calloriopsis } \\
\text { clade }\end{array}$ & Corticifraga, Calloriopsis, Spirosphaera \\
\hline Triblidiales & Triblidiaceae & Huangshania, Pseudographis, Triblidium \\
\hline
\end{tabular}


Table 1 Continued.

\begin{tabular}{ll}
\hline $\begin{array}{l}\text { Order/Order-level } \\
\text { clade }\end{array}$ & Family/Family-level clade Genera \\
\hline Leotiomycetes genera & Adelodiscus, Aquadiscula, Ascluella, Ascoclavulina, Benguetia, Bioscypha, Bulgariopsis, Callerascus, Capillipes, \\
incertae sedis & Capricola, Cejpia, Cenangiumella, Chlorospleniella, Chondroderris, Ciliella, Coleosperma, Coronellaria, \\
& Crumenella, Cryptohymenium, Dawsicola, Dermateopsis, Dictyonia, Didonia, Echinodiscus, Episclerotium, \\
& Erikssonopsis, Gloeopeziza, Godroniopsis, Grimmicola, Helotiella, Hemiglossum, Hymenobolus, Hyphoscypha, \\
& Hysteronaevia, Hysteropezizella, Involucroscypha, Jacobsonia, Lasseria, Livia, Masseea, Melanopeziza, Melanormia, \\
& Metapezizella, Mycosphaerangium, Obconicum, Obscurodiscus, Ocotomyces, Otwaya, Parencoelia, Patinellaria, \\
& Pezolepis, Pezomela, Phaeofabraea, Phragmonaevia, Phyllopezis, Physmatomyces, Pleoscutula, Podophacidium, \\
& Polydiscidium, Polydiscina, Potridiscus, Pseudolachnum, Pseudopeltis, Pseudotryblidium, Psilophana, Psilothecium, \\
& Pubigera, Rhizocalyx, Riedera, Sambucina, Schnablia, Sclerocrana, Sinofavus, Sorokina, Sorokinella, Stilbopeziza, \\
& Tovariella, Trichohelotium, Waltonia, Woodiella, Xeromedulla, Zugazaea, Bagnisimitrula, Themisia, Scutulopsis, \\
& Sageria, Rhizothyrium, Radotinea, Algincola, Apiculospora, Pteromyces, Patinellaria, Pachydisca, \\
& Monochaetiellopsis, Microdiscus, Merodontis, Libartania, Lemalis, Larissia, Grovesia, Discomycella, Cryptopezia, \\
Criserosphaeria, Cornuntum, Comesia, Chloroepilichen
\end{tabular}

Table 2 Comparison of major morphological characteristics of the families of Leotiomycetes (Orders and order-level clades are grey highlighted)

\begin{tabular}{|c|c|c|c|c|c|}
\hline Family & Ascomata & Excipulum/ Peridium & Paraphyses & Asci & Ascospores \\
\hline \multicolumn{6}{|l|}{ Chaetomellales } \\
\hline Chaetomellaceae & $\begin{array}{l}\text { Apothecial, sessile to } \\
\text { substipitate, erumpent initially } \\
\text { develop beneath epidermis, and } \\
\text { covered with hairs or setae }\end{array}$ & $\begin{array}{l}\text { Ectal excipulum textura } \\
\text { angularis to globulosa or } \\
\text { textura prismatica to porrecta } \\
\text { cells, medullary excipulum } \\
\text { textura prismatica to porrecta } \\
\text { cells }\end{array}$ & $\begin{array}{l}\text { Filiform, } \\
\text { apically } \\
\text { branched }\end{array}$ & $\begin{array}{l}\text { 8-spored, cylindric- } \\
\text { clavate, non- } \\
\text { amyloid, arising } \\
\text { from croziers }\end{array}$ & $\begin{array}{l}\text { Ellipsoid to fusoid, hyaline, } \\
\text { aseptate }\end{array}$ \\
\hline $\begin{array}{l}\text { Marthamycetacea } \\
e\end{array}$ & $\begin{array}{l}\text { Apothecial, rounded to } \\
\text { elongated, semi-immersed, } \\
\text { opening by irregular splits in } \\
\text { epihymenium or median } \\
\text { longitudinal split with adhering } \\
\text { host tissue }\end{array}$ & $\begin{array}{l}\text { Ectal excipulum mostly } \\
\text { reduced or textura angularis } \\
\text { or oblita cells, medullary } \\
\text { excipulum textura oblita cells }\end{array}$ & $\begin{array}{l}\text { Filiform, } \\
\text { densely } \\
\text { septate, } \\
\text { frequently } \\
\text { anastomosing }\end{array}$ & $\begin{array}{l}\text { 8-spored or multi- } \\
\text { spored, cylindrical } \\
\text { to sub-cylindrical } \\
\text { or clavate, non- } \\
\text { amyloid or rarely } \\
\text { amyloid, arising } \\
\text { from croziers }\end{array}$ & $\begin{array}{l}\text { Ellipsoid to cylindrical or } \\
\text { filiform, straight or curved, } \\
\text { septate, } \\
\text { muriform, } \\
\text { sometimes with gelatinous } \\
\text { sheath or gelatinous caps at } \\
\text { each apex }\end{array}$ \\
\hline
\end{tabular}


Table 2 Continued.

\begin{tabular}{|c|c|c|c|c|c|}
\hline Family & Ascomata & Excipulum/ Peridium & Paraphyses & Asci & Ascospores \\
\hline \multicolumn{6}{|l|}{ Cyttariales } \\
\hline Cyttariaceae & $\begin{array}{l}\text { Apothecial, many apothecia } \\
\text { immersed in a sterile fleshy- } \\
\text { gelatinous stroma }\end{array}$ & Not clear & $\begin{array}{l}\text { Simple } \\
\text { filiform }\end{array}$ & 8-spored, amyloid & $\begin{array}{l}\text { Subglobose to ovoid, } \\
\text { aseptate, smooth to } \\
\text { rugulose, at first hyaline to } \\
\text { yellowish and later } \\
\text { becoming pigmented }\end{array}$ \\
\hline Cordieritidaceae & $\begin{array}{l}\text { Apothecial, discoid, cupulate, } \\
\text { funnel-shaped or ear shaped, } \\
\text { sessile or stipitate, sometimes } \\
\text { arising from common base or } \\
\text { from branched stipes with a } \\
\text { dark stroma, sometimes } \\
\text { covered with hairs }\end{array}$ & $\begin{array}{l}\text { Ectal excipulum textura } \\
\text { globulosa-angularis or } \\
\text { textura prismatica-intricata } \\
\text { cells, medullary excipulum } \\
\text { textura prismatica-intricata or } \\
\text { textura epidermoidea cells }\end{array}$ & $\begin{array}{l}\text { Cylindrical, } \\
\text { clavate or } \\
\text { lanceolate, } \\
\text { apically } \\
\text { slightly } \\
\text { swollen and } \\
\text { gelatinized, } \\
\text { septate }\end{array}$ & $\begin{array}{l}\text { 8-spored, non- } \\
\text { amyloid, arising } \\
\text { from croziers }\end{array}$ & $\begin{array}{l}\text { Ellipsoid to fusoid or rod- } \\
\text { shaped, straight or } \\
\text { sometimes curved, hyaline } \\
\text { or olivaceous-brown, 0-3- } \\
\text { septate }\end{array}$ \\
\hline Deltopyxidaceae & $\begin{array}{l}\text { Apothecial, cupulate to discoid, } \\
\text { sessile to substipitate }\end{array}$ & $\begin{array}{l}\text { Ectal excipulum textura } \\
\text { prismatica-globulosa- } \\
\text { angularis cells, medullary } \\
\text { excipulum textura globulosa- } \\
\text { angularis-prismatica cells }\end{array}$ & $\begin{array}{l}\text { Filiform, } \\
\text { clavate- } \\
\text { capitate, } \\
\text { apically } \\
\text { slightly } \\
\text { swollen and } \\
\text { covered with } \\
\text { gell sheath, } \\
\text { septate }\end{array}$ & $\begin{array}{l}\text { 64-spored, clavate- } \\
\text { fusoid, non- } \\
\text { amyloid, opening } \\
\text { by a large slit-like } \\
\text { pore, arising from } \\
\text { croziers }\end{array}$ & $\begin{array}{l}\text { Slightly to strongly } \\
\text { triangular, guttulate }\end{array}$ \\
\hline \multicolumn{6}{|l|}{ Erysiphales } \\
\hline $\begin{array}{l}\text { Amorphothecacea } \\
e\end{array}$ & $\begin{array}{l}\text { Cleistothecial or Apothecial, } \\
\text { cleistothecia globose, } \\
\text { sometimes with funnel- shaped } \\
\text { apical outgrowths, apothecia } \\
\text { cupulate-turbinate, sessile, } \\
\text { covered with hairs }\end{array}$ & $\begin{array}{l}\text { Peridium thick-walled brown } \\
\text { hyphae with appendages. } \\
\text { Excipulum textura angularis }\end{array}$ & $\begin{array}{l}\text { Filiform, } \\
\text { branched at } \\
\text { the apices }\end{array}$ & $\begin{array}{l}\text { 8-spored, sub- } \\
\text { clavate to globose } \\
\text { or cylindric- } \\
\text { clavate, sometimes } \\
\text { amyloid, arising } \\
\text { from croziers, } \\
\text { sometimes } \\
\text { evanescent }\end{array}$ & $\begin{array}{l}\text { Ellipsoid to fusoid, } \\
\text { navicular or lenticular, } \\
\text { hyaline, smooth or striate, } \\
\text { hyaline, 0-3-septate }\end{array}$ \\
\hline
\end{tabular}


Table 2 Continued.

\begin{tabular}{|c|c|c|c|c|c|}
\hline Family & Ascomata & Excipulum/ Peridium & Paraphyses & Asci & Ascospores \\
\hline \multicolumn{6}{|l|}{ Erysiphales } \\
\hline Erysiphaceae & $\begin{array}{l}\text { Cleistothecial (chasmothecial), } \\
\text { globose }\end{array}$ & $\begin{array}{l}\text { Peridium textura } \\
\text { angularis sells }\end{array}$ & Absent & $\begin{array}{l}\text { 2-8-spored, globose } \\
\text { to broadly clavate, } \\
\text { open by rupturing at } \\
\text { the apices }\end{array}$ & $\begin{array}{l}\text { Subglobose to } \\
\text { ellipsoid, aseptate, } \\
\text { hyaline to yellowish, } \\
\text { without a sheath }\end{array}$ \\
\hline \multicolumn{6}{|l|}{ Flagellospora clade } \\
\hline $\begin{array}{l}\text { Flagellospora } \\
\text { clade }\end{array}$ & $\begin{array}{l}\text { Perithecial, subglobose with } \\
\text { conspicuously papillate ostiole }\end{array}$ & $\begin{array}{l}\text { Peridium textura } \\
\text { angularis cells }\end{array}$ & $\begin{array}{l}\text { Filiform, } \\
\text { cylindrical to } \\
\text { capitate, straight, } \\
\text { unbranched, } \\
\text { densely septate }\end{array}$ & 8-spored, cylindrical & $\begin{array}{l}\text { Ellipsoid to fusiform, } \\
\text { 1-septate, guttulate, } \\
\text { smooth, hyaline }\end{array}$ \\
\hline \multicolumn{6}{|l|}{ Helotiales } \\
\hline Amicodiscaceae & $\begin{array}{l}\text { Apothecial, cupulate, sessile or } \\
\text { sub-stipitate, margins covered } \\
\text { by hairs }\end{array}$ & $\begin{array}{l}\text { Ectal excipulum textura } \\
\text { angularis or textura } \\
\text { prismatica cells, } \\
\text { medullary excipulum } \\
\text { loosely arranged hyphae }\end{array}$ & $\begin{array}{l}\text { Filiform, } \\
\text { cylindrical, septate, } \\
\text { simple }\end{array}$ & $\begin{array}{l}\text { 8-spored, amyloid, } \\
\text { sometimes arising } \\
\text { from croziers }\end{array}$ & $\begin{array}{l}\text { Ellipsoid to fusoid, } \\
\text { aseptate, guttulate, } \\
\text { lemon-yellow } \\
\text { pigmented }\end{array}$ \\
\hline $\begin{array}{l}\text { Aquapoterium- } \\
\text { Unguicularia } \\
\text { clade }\end{array}$ & $\begin{array}{l}\text { Apothecial, cupulate } \\
\text { receptacle, sessile or stipitate, } \\
\text { sometimes margins covered } \\
\text { with short cylindrical hairs }\end{array}$ & $\begin{array}{l}\text { Ectal excipulum textura } \\
\text { prismatica cells or a single } \\
\text { layer of parallel hyphae } \\
\text { with enlarged, globose } \\
\text { apices, medullary } \\
\text { excipulum reduced or } \\
\text { composed of loosely } \\
\text { arranged hyphae }\end{array}$ & $\begin{array}{l}\text { Filiform, hyaline, } \\
\text { obtuse to clavate at } \\
\text { apex, septate, } \\
\text { smooth-walled, } \\
\text { simple or branched }\end{array}$ & $\begin{array}{l}\text { 8-spored, amyloid or } \\
\text { non-amyloid, } \\
\text { cylindric-clavate }\end{array}$ & $\begin{array}{l}\text { Ellipsoid to clavate- } \\
\text { cylindric, hyaline, } \\
\text { smooth-walled, } 0-1- \\
\text { septate, surrounded by } \\
\text { a gelatinous sheath }\end{array}$ \\
\hline $\begin{array}{l}\text { Arachnopezizacea } \\
e\end{array}$ & Apothecial, covered by hairs & $\begin{array}{l}\text { Ectal excipulum textura } \\
\text { angularis to prismatica } \\
\text { cells, medullary } \\
\text { excipulum textura } \\
\text { prismatica to textura } \\
\text { oblita cells }\end{array}$ & Cylindrical, hyaline & $\begin{array}{l}\text { 8-spored, cylindric- } \\
\text { clavate, amyloid, } \\
\text { arising from croziers }\end{array}$ & $\begin{array}{l}\text { Ellipsoid to fusoid, } 0- \\
\text { 7-septate }\end{array}$ \\
\hline
\end{tabular}


Table 2 Continued.

\begin{tabular}{|c|c|c|c|c|c|}
\hline Family & Ascomata & Excipulum/ Peridium & Paraphyses & Asci & Ascospores \\
\hline \multicolumn{6}{|l|}{ Helotiales } \\
\hline Bryoglossaceae & $\begin{array}{l}\text { Apothecial, clavate to capitate } \\
\text { or cupulate to turbinate, long } \\
\text { stipitate, gelatinous }\end{array}$ & $\begin{array}{l}\text { Ectal excipulum textura } \\
\text { porrecta cells, medullary } \\
\text { excipulum textura } \\
\text { intricata cells }\end{array}$ & $\begin{array}{l}\text { Filiform, swollen at } \\
\text { the apex }\end{array}$ & $\begin{array}{l}\text { 8-spored, amyloid or } \\
\text { non-amyloid, arising } \\
\text { from croziers }\end{array}$ & $\begin{array}{l}\text { Ellipsoid to fusoid, } \\
\text { straight, aseptate, } \\
\text { guttulate }\end{array}$ \\
\hline Bulgariella clade & $\begin{array}{l}\text { Apothecial or rarely } \\
\text { cleistothecial, cupulate, } \\
\text { discoid, turbinate or capitate, } \\
\text { sessile or stipitate, margins and } \\
\text { flanks are covered with hairs }\end{array}$ & $\begin{array}{l}\text { Ectal excipulum is } \\
\text { composed textura } \\
\text { angularis, textura } \\
\text { prismatica or textura } \\
\text { oblita cells, medullary } \\
\text { excipulum is composed of } \\
\text { cells of textura intricata or } \\
\text { textura oblita cells }\end{array}$ & $\begin{array}{l}\text { Filiform, lanceolate } \\
\text { or cylindrical }\end{array}$ & $\begin{array}{l}\text { 8-spored, cylindric- } \\
\text { clavate, amyloid or } \\
\text { non-amyloid, } \\
\text { sometimes arising } \\
\text { from croziers }\end{array}$ & $\begin{array}{l}\text { Globose, ellipsoid to } \\
\text { filiform, septate or } \\
\text { aseptate, hyaline or } \\
\text { brownish, guttulate }\end{array}$ \\
\hline Chlorospleniaceae & $\begin{array}{l}\text { Apothecial, cupulate or discoid, } \\
\text { sessile or substipitate }\end{array}$ & $\begin{array}{l}\text { Ectal excipulum textura } \\
\text { angularis cells, medullary } \\
\text { excipulum textura } \\
\text { intricata cells }\end{array}$ & Filiform, septate & $\begin{array}{l}\text { 8-spored, cylindric- } \\
\text { clavate, amyloid }\end{array}$ & $\begin{array}{l}\text { Ellipsoid to fusoid, } \\
\text { hyaline and smooth } \\
\text { walled }\end{array}$ \\
\hline Colipila clade & $\begin{array}{l}\text { Apothecial cupulate, covered } \\
\text { by long cylindrical hairs }\end{array}$ & $\begin{array}{l}\text { Ectal excipulum and } \\
\text { medullary excipulum } \\
\text { textura prismatica cells }\end{array}$ & $\begin{array}{l}\text { Dimorphic, sub- } \\
\text { cylindrical and not } \\
\text { exceed the length } \\
\text { of asci, or broadly } \\
\text { lanceolate and } \\
\text { exceed the length } \\
\text { of asci }\end{array}$ & $\begin{array}{l}8 \text {-spored, cylindric- } \\
\text { clavate, amyloid, } \\
\text { arising from croziers }\end{array}$ & Ellipsoid to fusoid \\
\hline Discinellaceae & $\begin{array}{l}\text { Apothecial, discoid to cupulate, } \\
\text { circular, gelatinous, sometimes } \\
\text { covered with hairs }\end{array}$ & $\begin{array}{l}\text { Ectal excipulum textura } \\
\text { prismatica or textura } \\
\text { porrecta cells, medullary } \\
\text { excipulum textura } \\
\text { intricata to prismatica } \\
\text { cells }\end{array}$ & $\begin{array}{l}\text { Filiform, branched } \\
\text { at the apices }\end{array}$ & $\begin{array}{l}\text { 8-spored, cylindrical, } \\
\text { amyloid or non- } \\
\text { amyloid, sometimes } \\
\text { arising from croziers }\end{array}$ & $\begin{array}{l}\text { Ellipsoid, aseptate, } \\
\text { hyaline, without sheath }\end{array}$ \\
\hline $\begin{array}{l}\text { Drepanopezizacea } \\
e\end{array}$ & $\begin{array}{l}\text { Apothecial, cupulate, sessile, } \\
\text { mostly immersed }\end{array}$ & $\begin{array}{l}\text { A thin layer of textura } \\
\text { angularis cells, }\end{array}$ & $\begin{array}{l}\text { Apically slightly } \\
\text { swollen, straight }\end{array}$ & $\begin{array}{l}\text { 4-8- spored, non- } \\
\text { amyloid }\end{array}$ & $\begin{array}{l}\text { Ellipsoid to fusoid, } 0 \text { - } \\
\text { 2-septate }\end{array}$ \\
\hline
\end{tabular}


Table 2 Continued.

\begin{tabular}{|c|c|c|c|c|c|}
\hline Family & Ascomata & Excipulum/ Peridium & Paraphyses & Asci & Ascospores \\
\hline \multicolumn{6}{|l|}{ Helotiales } \\
\hline Gelatinodiscaceae & $\begin{array}{l}\text { Apothecial, cupulate or discoid, } \\
\text { some are tremelloid, form } \\
\text { cerebriform masses which each } \\
\text { lobule contains a turbinate } \\
\text { apothecium }\end{array}$ & $\begin{array}{l}\text { Ectal excipulum textura } \\
\text { prismatica to textura } \\
\text { angularis to globulosa } \\
\text { cells, medullary } \\
\text { excipulum textura oblita } \\
\text { to textura porrecta or } \\
\text { textura intricata cells }\end{array}$ & $\begin{array}{l}\text { Filiform, } \\
\text { cylindrical, apically } \\
\text { swollen, guttulate }\end{array}$ & $\begin{array}{l}\text { 8-spored, amyloid, } \\
\text { arising from croziers }\end{array}$ & $\begin{array}{l}\text { Ellipsoid to fusoid, } \\
\text { hyaline, yellowish or } \\
\text { brownish, smooth, with } \\
\text { a gelatinous sheath, } \\
\text { guttulate, 0-5-septate }\end{array}$ \\
\hline Godroniaceae & $\begin{array}{l}\text { Apothecial, urceolate, discoid } \\
\text { or cupulate, mostly stromatic, } \\
\text { erumpent, sometimes covered } \\
\text { with hairs }\end{array}$ & $\begin{array}{l}\text { Ectal excipulum textura } \\
\text { prismatica to angularis } \\
\text { cells, medullary } \\
\text { excipulum textura } \\
\text { epidermoidea, prismatica } \\
\text { to porrecta cells }\end{array}$ & $\begin{array}{l}\text { Filiform or } \\
\text { lanceolate, simple } \\
\text { or branched, } \\
\text { sometimes slightly } \\
\text { swollen at the apex }\end{array}$ & $\begin{array}{l}\text { 8-spored, cylindric- } \\
\text { clavate, amyloid or } \\
\text { non-amyloid }\end{array}$ & $\begin{array}{l}\text { Fusoid, hyaline, } \\
\text { septate, guttulate }\end{array}$ \\
\hline Helotiaceae & $\begin{array}{l}\text { Apothecial, cupulate, discoid, } \\
\text { capitate to clavate, turbinate or } \\
\text { globose, sessile or stipitate, } \\
\text { margins and flanks smooth or } \\
\text { covered with hairs }\end{array}$ & $\begin{array}{l}\text { Ectal excipulum textura } \\
\text { prismatica, intricata, } \\
\text { globulosa-angularis, or } \\
\text { toblita cells, medullary } \\
\text { excipulum textura } \\
\text { intricata or porrecta cells }\end{array}$ & $\begin{array}{l}\text { Cylindrical, septate } \\
\text { or aseptate, hyaline } \\
\text { to yellowish, } \\
\text { guttulate }\end{array}$ & $\begin{array}{l}\text { 4-8-spored, } \\
\text { cylindric-clavate, } \\
\text { amyloid or non- } \\
\text { amyloid, sometimes } \\
\text { arising from croziers }\end{array}$ & $\begin{array}{l}\text { Ellipsoid, fusoid or } \\
\text { filiform, 1-3-septate, } \\
\text { rarely ornamented }\end{array}$ \\
\hline $\begin{array}{l}\text { Heterosphaeriace } \\
\text { ae }\end{array}$ & $\begin{array}{l}\text { Apothecial, discoid, black, } \\
\text { sessile, erumpent, gelatinous }\end{array}$ & $\begin{array}{l}\text { Ectal excipulum textura } \\
\text { angularis cells, medullary } \\
\text { excipulum textura } \\
\text { porrecta cells }\end{array}$ & $\begin{array}{l}\text { Clavate contains } \\
\text { many guttules }\end{array}$ & $\begin{array}{l}8 \text {-spored, amyloid, } \\
\text { arising from croziers }\end{array}$ & $\begin{array}{l}\text { Aseptate, ellipsoid to } \\
\text { fusoid, without gel } \\
\text { sheath }\end{array}$ \\
\hline Hyaloscyphaceae & $\begin{array}{l}\text { Apothecial, cupulate or discoid, } \\
\text { sessile or substipitate, } \\
\text { sometimes covered with hairs }\end{array}$ & $\begin{array}{l}\text { Ectal excipulum textura } \\
\text { globulosa cells, medullary } \\
\text { excipulum textura } \\
\text { porrecta, intricata to } \\
\text { oblita cells }\end{array}$ & $\begin{array}{l}\text { Filiform, septate, } \\
\text { branched, slightly } \\
\text { swollen at the } \\
\text { apices }\end{array}$ & $\begin{array}{l}8 \text {-spored, cylindric- } \\
\text { clavate, amyloid, } \\
\text { arising from croziers }\end{array}$ & $\begin{array}{l}\text { Ellipsoid to fusoid, } \\
\text { aseptate or septate, } \\
\text { hyaline }\end{array}$ \\
\hline Hydrocinaceae & $\begin{array}{l}\text { Apothecial, cupulate, sessile or } \\
\text { substipitate }\end{array}$ & $\begin{array}{l}\text { Ectal excipulum textura } \\
\text { globulosa cells, medullary } \\
\text { excipulum textura } \\
\text { porrecta, intricata } \text { or } \\
\text { oblita cells }\end{array}$ & $\begin{array}{l}\text { Filiform, septate, } \\
\text { branched, slightly } \\
\text { swollen at the } \\
\text { apices }\end{array}$ & $\begin{array}{l}\text { 8-spored, cylindric- } \\
\text { clavate, amyloid, } \\
\text { arising from croziers }\end{array}$ & $\begin{array}{l}\text { Ellipsoid to fusoid, } \\
\text { aseptate or septate, } \\
\text { hyaline }\end{array}$ \\
\hline
\end{tabular}


Table 2 Continued.

\begin{tabular}{|c|c|c|c|c|c|}
\hline Family & Ascomata & Excipulum/ Peridium & Paraphyses & Asci & Ascospores \\
\hline \multicolumn{6}{|l|}{ Helotiales } \\
\hline Lachnaceae & $\begin{array}{l}\text { Apothecial, cupulate or discoid, } \\
\text { sessile or stipitate, margins and } \\
\text { flanks are covered with hairs }\end{array}$ & $\begin{array}{l}\text { Ectal excipulum textura } \\
\text { angularis, prismatica or } \\
\text { oblita cells, medullary } \\
\text { excipulum textura } \\
\text { intricata or textura oblita } \\
\text { cells }\end{array}$ & $\begin{array}{l}\text { Filiform, lanceolate } \\
\text { or rarely cylindrical }\end{array}$ & $\begin{array}{l}\text { 8-spored, cylindric- } \\
\text { clavate, amyloid or } \\
\text { non-amyloid, } \\
\text { sometimes arising } \\
\text { from croziers }\end{array}$ & $\begin{array}{l}\text { Globose, ellipsoid to } \\
\text { filiform or allantoid, } \\
\text { septate or aseptate, } \\
\text { hyaline, guttulate }\end{array}$ \\
\hline Loramycetaceae & $\begin{array}{l}\text { Apothecial or perithecial, } \\
\text { apothecia cupulate or pulvinate, } \\
\text { perithecia sub-globose }\end{array}$ & $\begin{array}{l}\text { Ectal excipulum textura } \\
\text { prismatica, angularis or } \\
\text { globulosa cells, medullary } \\
\text { excipulum textura } \\
\text { prismatica cells }\end{array}$ & $\begin{array}{l}\text { Filiform, septate, } \\
\text { unbranched, } \\
\text { sometimes apically } \\
\text { swollen and } \\
\text { pigmented }\end{array}$ & $\begin{array}{l}\text { 8-spored, cylindric- } \\
\text { clavate, amyloid or } \\
\text { non-amyloid }\end{array}$ & $\begin{array}{l}\text { Fusiform, septate, } \\
\text { sometimes with } \\
\text { terminal appendages } \\
\text { and gel sheath }\end{array}$ \\
\hline Mitrulaceae & Apothecial, clavate, stipitate & $\begin{array}{l}\text { Ectal excipulum textura } \\
\text { porrecta cells, medullary } \\
\text { excipulum textura } \\
\text { intricata cells }\end{array}$ & $\begin{array}{l}\text { Filiform, } \\
\text { cylindrical, with } \\
\text { yellow carotenoid } \\
\text { droplets }\end{array}$ & $\begin{array}{l}\text { 8-spored, cylindric- } \\
\text { clavate, arising from } \\
\text { croziers }\end{array}$ & $\begin{array}{l}\text { Fusoid to ellipsoid, } \\
\text { straight or curved }\end{array}$ \\
\hline Mollisiaceae & $\begin{array}{l}\text { Apothecial, discoid covered by } \\
\text { hairs, }\end{array}$ & $\begin{array}{l}\text { Ectal excipulum textura } \\
\text { globulosa to angularis } \\
\text { cells, medullary } \\
\text { excipulum textura } \\
\text { prismatica cells }\end{array}$ & $\begin{array}{l}\text { Cylindrical or } \\
\text { lanceolate, apically } \\
\text { swollen, guttulate }\end{array}$ & $\begin{array}{l}\text { 8-spored, amyloid, } \\
\text { cylindric clavate, } \\
\text { mostly arising from } \\
\text { croziers }\end{array}$ & $\begin{array}{l}\text { Ellipsoid to long- } \\
\text { filiform, } 0-7 \text {-septate, } \\
\text { guttulate }\end{array}$ \\
\hline $\begin{array}{l}\text { Patellariopsis } \\
\text { clade }\end{array}$ & Apothecial, discoid, sessile & $\begin{array}{l}\text { Ectal excipulum textura } \\
\text { globulosa to angularis } \\
\text { cells, medullary } \\
\text { excipulum interwoven } \\
\text { refractive hyphae }\end{array}$ & $\begin{array}{l}\text { filiform, branched } \\
\text { and pigmented at } \\
\text { the apices }\end{array}$ & $\begin{array}{l}\text { 8-spored, cylindric- } \\
\text { clavate, amyloid }\end{array}$ & $\begin{array}{l}\text { Ellipsoid to fusoid, } \\
\text { hyaline, 3-7-septate }\end{array}$ \\
\hline $\begin{array}{l}\text { Peltigeromyces } \\
\text { clade }\end{array}$ & $\begin{array}{l}\text { Apothecial, cartilaginous, thin, } \\
\text { with a large variety of lobes }\end{array}$ & $\begin{array}{l}\text { Records are not available } \\
\text { for micro morphological } \\
\text { characters }\end{array}$ & - & - & - \\
\hline $\begin{array}{l}\text { Phialocephala } \\
\text { urceolata clade }\end{array}$ & Sexual morphs are not recorded & - & - & - & - \\
\hline
\end{tabular}


Table 2 Continued.

\begin{tabular}{|c|c|c|c|c|c|}
\hline Family & Ascomata & Excipulum/ Peridium & Paraphyses & Asci & Ascospores \\
\hline \multicolumn{6}{|l|}{ Helotiales } \\
\hline Ploettnerulaceae & $\begin{array}{l}\text { Apothecial, cupulate, discoid or } \\
\text { urn-shaped, sessile or sub- } \\
\text { stipitate, sometimes covered } \\
\text { with pigmented hairs }\end{array}$ & $\begin{array}{l}\text { Ectal excipulum textura } \\
\text { globulosa to angularis } \\
\text { cells, } \\
\text { excipulum medullary } \\
\text { prismatica } \text { cells }\end{array}$ & $\begin{array}{l}\text { Filiform, } \\
\text { cylindrical } \\
\text { lanceolate, } \\
\text { guttulate }\end{array}$ & $\begin{array}{l}\text { 8-spored, conical } \\
\text { apex, amyloid }\end{array}$ & $\begin{array}{l}\text { Ellipsoid to long- } \\
\text { filiform, } 0 \text {-3-septate, } \\
\text { guttulate }\end{array}$ \\
\hline Solenopeziaceae & $\begin{array}{l}\text { Apothecial cupulate, discoid or } \\
\text { pulvinate, sessile or stipitate, } \\
\text { sometimes covered with } \\
\text { hyaline, whitish, yellow or } \\
\text { brown, non-bristle like hairs }\end{array}$ & $\begin{array}{l}\text { Ectal excipulum textura } \\
\text { angularis, } \\
\text { prismatica or textura } \\
\text { oblita cells, medullary } \\
\text { excipulum } \\
\text { intricata or textura oblita } \\
\text { cells }\end{array}$ & $\begin{array}{l}\text { Filiform, lanceolate } \\
\text { or cylindrical }\end{array}$ & $\begin{array}{l}\text { 8-spored, cylindric- } \\
\text { clavate, amyloid or } \\
\text { non-amyloid, } \\
\text { sometimes arising } \\
\text { from croziers }\end{array}$ & $\begin{array}{l}\text { Globose, ellipsoid to } \\
\text { fusiform, septate or } \\
\text { aseptate, guttulate }\end{array}$ \\
\hline Vibrisseaceae & $\begin{array}{l}\text { Apothecial, cupulate or clavate, } \\
\text { sessile to stipitate }\end{array}$ & $\begin{array}{l}\text { Ectal excipulum textura } \\
\text { angularis to globulosa } \\
\text { cells, medullary } \\
\text { excipulum reduced or } \\
\text { textura oblita cells }\end{array}$ & $\begin{array}{l}\text { Filiform, apically } \\
\text { slightly swollen, } \\
\text { sometimes } \\
\text { branched }\end{array}$ & $\begin{array}{l}\text { 8-spored, cylindric- } \\
\text { clavate, } r \text { long } \\
\text { stipitate, sometimes } \\
\text { amyloid, arising from } \\
\text { croziers }\end{array}$ & $\begin{array}{l}\text { Filiform, 3-24-septate, } \\
\text { partly fragmenting }\end{array}$ \\
\hline \multicolumn{6}{|c|}{ Helicogoniaceae clade } \\
\hline Helicogoniaceae & $\begin{array}{ll}\text { Absent, forms only naked on } \\
\text { ascogenous hyphae } & \text { or } \\
\text { apothecial semiglobose } & \text { to } \\
\text { pulvinate, gelatinous } & \end{array}$ & $\begin{array}{l}\text { Ectal excipulum of textura } \\
\text { prismatica to angularis to } \\
\text { porrecta, medullary } \\
\text { excipulum not clear }\end{array}$ & Filiform, simple & $\begin{array}{l}\text { 8-spored, cylindric- } \\
\text { clavate, amyloid or } \\
\text { non-amyloid, } \\
\text { opening by an apical } \\
\text { slit }\end{array}$ & $\begin{array}{l}\text { Subglobose to ellipsoid } \\
\text { to fusoid }\end{array}$ \\
\hline \multicolumn{6}{|c|}{ Hyphodiscus- chalara clade } \\
\hline Hyphodiscaceae & $\begin{array}{l}\text { Apothecial, cupulate or discoid, } \\
\text { sessile or short stalked, } \\
\text { sometimes gelatinized and } \\
\text { covered with hairs }\end{array}$ & $\begin{array}{l}\text { Ectal excipulum textura } \\
\text { angularis, intricata or } \\
\text { prismatica cells, } \\
\text { medullary excipulum } \\
\text { textura intricata to } \\
\text { angularis cells }\end{array}$ & $\begin{array}{l}\text { Filiform, septate, } \\
\text { slightly enlarged at } \\
\text { the apices }\end{array}$ & $\begin{array}{l}\text { 8-spored, cylindric- } \\
\text { clavate, amyloid or } \\
\text { non-amyloid, } \\
\text { sometimes arising } \\
\text { from croziers }\end{array}$ & $\begin{array}{l}\text { Ellipsoid, hyaline, } 0-3- \\
\text { septate }\end{array}$ \\
\hline
\end{tabular}


Table 2 Continued.

\begin{tabular}{|c|c|c|c|c|c|}
\hline Family & Ascomata & Excipulum/ Peridium & Paraphyses & Asci & Ascospores \\
\hline \multicolumn{6}{|c|}{ Hyphodiscus- chalara clade } \\
\hline \multirow[t]{2}{*}{$\begin{array}{l}\text { Hamatocanthoscy } \\
\text { phaceae }\end{array}$} & \multirow[t]{2}{*}{$\begin{array}{l}\text { Apothecial, cupulate or discoid } \\
\text { receptacle, sessile, rarely } \\
\text { stipitate, erumpent }\end{array}$} & \multirow{2}{*}{$\begin{array}{l}\text { Ectal excipulum reduced } \\
\text { or textura intricata or } \\
\text { prismatica cells, } \\
\text { medullary excipulum } \\
\text { textura intricata or } \\
\text { prismatica cells }\end{array}$} & $\begin{array}{l}\text { Filiform, slightly } \\
\text { swollen at the } \\
\text { apices }\end{array}$ & \multirow[t]{2}{*}{$\begin{array}{l}\text { 8-spored, } \\
\text { amyloid, cylindric- } \\
\text { clavate, sometimes } \\
\text { arising from croziers }\end{array}$} & \multirow[t]{2}{*}{$\begin{array}{l}\text { Ellipsoid to fusoid, } \\
\text { hyaline, 0-1-septate }\end{array}$} \\
\hline & & & & & \\
\hline \multicolumn{6}{|l|}{ Lahmiales } \\
\hline Lahmiaceae & $\begin{array}{l}\text { Apothecial, turbinate, stipitate, } \\
\text { black, closed at immature stage } \\
\text { and open by irregular radial } \\
\text { splits at maturity }\end{array}$ & $\begin{array}{l}\text { Ectal excipulum textura } \\
\text { epidermoidear cells, } \\
\text { medullary excipulum } \\
\text { textura epidermoidea cells }\end{array}$ & $\begin{array}{l}\text { Densely septate, } \\
\text { unbranched, } \\
\text { slightly swollen at } \\
\text { apices }\end{array}$ & $\begin{array}{l}\text { 8-spored, cylindric- } \\
\text { clavate, non-amyloid, } \\
\text { arising from croziers, } \\
\text { bitunicate but non- } \\
\text { fissitunicate }\end{array}$ & $\begin{array}{l}\text { Crescent-shaped, } \\
\text { hyaline, 1-4-septate }\end{array}$ \\
\hline \multicolumn{6}{|l|}{ Lauriomycetales } \\
\hline Lauriomycetaceae & Do not form Sexual morphs & - & - & - & - \\
\hline \multicolumn{6}{|c|}{ Leptodontidiaceae clade } \\
\hline Leptodontidiaceae & Sexual morphs are not recorded & - & - & - & - \\
\hline \multicolumn{6}{|l|}{ Leotiales } \\
\hline $\begin{array}{l}\text { Cochlearomyceta } \\
\text { ceae }\end{array}$ & Do not form sexual morphs & - & - & - & - \\
\hline $\begin{array}{l}\text { Gelatinomyces } \\
\text { clade }\end{array}$ & $\begin{array}{l}\text { Apothecial, aggregated (but } \\
\text { well separated) in a single } \\
\text { stroma, pale grey to dark } \\
\text { coloured, soft gelatinous, } \\
\text { globose or pulvinate when } \\
\text { young, discoid to cupulate with } \\
\text { maturity, sessile }\end{array}$ & $\begin{array}{l}\text { Exciple dark } \\
\text { gelatinous }\end{array}$ & Simple, branched & $\begin{array}{l}\text { Multi-spored, } \\
\text { cylindrical, tapered at } \\
\text { the base, non- } \\
\text { amyloid }\end{array}$ & $\begin{array}{l}\text { Minute, hyaline, } \\
\text { globose to ovoid, } \\
\text { smooth-walled }\end{array}$ \\
\hline Leotiaceae & $\begin{array}{l}\text { Apothecial, clavate, turbinate to } \\
\text { applanate, sessile to long } \\
\text { stipitate with subglobose to } \\
\text { ellipsoid to fusoid fertile part, } \\
\text { sometimes gelatinous }\end{array}$ & $\begin{array}{l}\text { Ectal excipulum textura } \\
\text { intricata or textura } \\
\text { porrecta cells, medullary } \\
\text { excipulum } \\
\text { intricata cells }\end{array}$ & $\begin{array}{l}\text { Filiform, hyaline, } \\
\text { sometimes apically } \\
\text { slightly swollen } \\
\text { and/or branched, } \\
\text { straight to slightly } \\
\text { curved, aseptate }\end{array}$ & $\begin{array}{l}\text { 8-spored, mostly } \\
\text { amyloid, arising from } \\
\text { croziers }\end{array}$ & $\begin{array}{l}\text { Ellipsoid to fusoid, } \\
\text { rarely } \\
\text { guttulate, vermiform, } \\
\text { hyaline }\end{array}$ \\
\hline
\end{tabular}


Table 2 Continued.

\begin{tabular}{|c|c|c|c|c|c|}
\hline Family & Ascomata & Excipulum/ Peridium & Paraphyses & Asci & Ascospores \\
\hline \multicolumn{6}{|l|}{ Leotiales } \\
\hline Tympanidaceae & $\begin{array}{l}\text { Apothecial, discoid, turbinate } \\
\text { or pulvinate, solitary or } \\
\text { aggregated in an stroma, often } \\
\text { slightly gelatinous, sessile or } \\
\text { stipitate, erumpent or } \\
\text { superficial }\end{array}$ & $\begin{array}{l}\text { Ectal excipulum textura } \\
\text { globulosa to textura } \\
\text { oblita, textura prismatica } \\
\text { or textura intricata cells, } \\
\text { medullary excipulum } \\
\text { textura intricata cells }\end{array}$ & $\begin{array}{l}\text { Filiform, } \\
\text { cylindrical to } \\
\text { capitate, straight, } \\
\text { unbranched, } \\
\text { densely septate }\end{array}$ & $\begin{array}{l}\text { 4-8-spored, } \\
\text { cylindric-clavate, } \\
\text { mostly non-amyloid, } \\
\text { rarely amyloid, } \\
\text { arising from croziers }\end{array}$ & $\begin{array}{l}\text { Globose, } \\
\text { fusiform } \\
\text { cylindrical, } \\
\text { slightly sometimes } \\
\text { hyaline, } \\
\text { guttulate, } \\
\text { hyaline }\end{array}$ \\
\hline \multicolumn{6}{|l|}{ Lichinodiales } \\
\hline $\begin{array}{l}\text { Epicladonia- } \\
\text { Epithamnolia } \\
\text { clade }\end{array}$ & Do not form Sexual morphs & $\cos$ & $\cos$ & 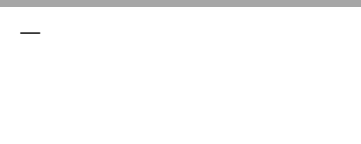 & - \\
\hline Lichinodiaceae & $\begin{array}{l}\text { Apothecial cupulate, turbinate } \\
\text { or pulvinate }\end{array}$ & $\begin{array}{l}\text { Excipulum pigmented, } \\
\text { tightly arranged hyphae or } \\
\text { textura intricata }\end{array}$ & $\begin{array}{lr}\text { Cylindrical } & \text { or } \\
\text { filiform, } & \text { septate, } \\
\text { sometimes } & \text { apically } \\
\text { swollen } & \text { and } \\
\text { pigmented } & \end{array}$ & $\begin{array}{l}8 \text {-spored, cylindrical- } \\
\text { clavate, non-amyloid, } \\
\text { arising from croziers }\end{array}$ & $\begin{array}{l}\text { Ellipsoid to pyriform } \\
\text { or globose to } \\
\text { subglobose, hyaline }\end{array}$ \\
\hline \multicolumn{6}{|l|}{ Medeolariales } \\
\hline Ascodichaenaceae & $\begin{array}{l}\text { Apothecial, round to elongate } \\
\text { hysterioid, opening by a stellate } \\
\text { fissure, carbonaceous }\end{array}$ & $\begin{array}{ll}\text { Excipulum reduced or } \\
\text { textura angularis to } \\
\text { globulosa cells }\end{array}$ & $\begin{array}{l}\text { Filiform, simple, } \\
\text { slightly apically } \\
\text { swollen }\end{array}$ & $\begin{array}{l}\text { 4-8-spored, broad } \\
\text { clavate-cylindric, } \\
\text { non-amyloid }\end{array}$ & $\begin{array}{l}\text { Ellipsoid to oblong, } 0- \\
\text { 1-septate, } \\
\text { granulate }\end{array}$ \\
\hline Ascocorticiaceae & $\begin{array}{l}\text { Apothecial, effuse, irregular in } \\
\text { shape, whitish-greyish or } \\
\text { ochraceous, pruinose film }\end{array}$ & $\begin{array}{l}\text { Excipulum } \quad \text { strongly } \\
\text { reduced }\end{array}$ & Simple, unbranched & $\begin{array}{l}\text { 4-16-spored, } \\
\text { cylindric-clavate, } \\
\text { inamyloid, with or } \\
\text { without croziers }\end{array}$ & $\begin{array}{l}\text { Cylindric-ellipsoid or } \\
\text { vermiform, } 0-11- \\
\text { septate, } \\
\text { eguttulate }\end{array}$ \\
\hline \multicolumn{6}{|l|}{ Medeolariales } \\
\hline $\begin{array}{l}\text { Coleophoma- } \\
\text { Parafabraea clade }\end{array}$ & $\begin{array}{l}\text { Apothecial, turbinate, sessile to } \\
\text { sub-sessile, short-stalked, } \\
\text { covered by setae-like structures }\end{array}$ & $\begin{array}{ll}\text { Excipulum reduced or } \\
\text { textura angularis to } \\
\text { globulosa cells }\end{array}$ & $\begin{array}{l}\text { Cylindrical, } \\
\text { slender, wider at } \\
\text { base, septate, apex } \\
\text { round, hyaline to } \\
\text { pale brown }\end{array}$ & $\begin{array}{l}\text { 8-spored, clavate to } \\
\text { cylindrical-clavate, } \\
\text { short-stipitate }\end{array}$ & $\begin{array}{l}\text { Fusoid to ellipsoid, in- } \\
\text { equilateral, ends } \\
\text { rounded, straight or } \\
\text { slightly curved, } \\
\text { aseptate, thin-walled, } \\
\text { hyaline, guttulate }\end{array}$ \\
\hline
\end{tabular}


Table 2 Continued.

\begin{tabular}{|c|c|c|c|c|c|}
\hline Family & Ascomata & Excipulum/ Peridium & Paraphyses & Asci & Ascospores \\
\hline \multicolumn{6}{|l|}{ Medeolariales } \\
\hline Dermateaceae & $\begin{array}{l}\text { Apothecial, cupulate to sub- } \\
\text { spherical, urceolate or discoid, } \\
\text { sessile or short stipitate }\end{array}$ & $\begin{array}{l}\text { Ectal excipulum reduced } \\
\text { or textura angularis to } \\
\text { globulosa cells, medullary } \\
\text { excipulum textura } \\
\text { angularis cells }\end{array}$ & $\begin{array}{l}\text { Filiform, apically } \\
\text { slightly swollen, } \\
\text { septate, branched }\end{array}$ & $\begin{array}{l}\text { 4-8-spored, } \\
\text { cylindric-clavate, } \\
\text { amyloid or non- } \\
\text { amyloid, arising from } \\
\text { croziers }\end{array}$ & $\begin{array}{l}\text { Ellipsoid-oblong, } \\
\text { hyaline, aseptate, } \\
\text { sometimes with a } \\
\text { delicate } \\
\text { guttulate }\end{array}$ \\
\hline Medeolariaceae & $\begin{array}{l}\text { Apothecial, irregularly } \\
\text { organized, reduced, erumpent } \\
\text { in host tissue }\end{array}$ & $\begin{array}{l}\text { Excipulum reduced or } \\
\text { unclear }\end{array}$ & $\begin{array}{l}\text { Filiform, simple, } \\
\text { flexuous, septate } \\
\text { below, brownish }\end{array}$ & $\begin{array}{l}\text { 8-spored, cylindric- } \\
\text { clavate, non-amyloid }\end{array}$ & $\begin{array}{l}\text { Fusiform to naviculate, } \\
\text { with a dark outer wall } \\
\text { layer with striations }\end{array}$ \\
\hline \multicolumn{6}{|l|}{ Micraspis lineage } \\
\hline Micraspis lineage & $\begin{array}{l}\text { Apothecial, immersed within } \\
\text { the substrate, elliptical, opening } \\
\text { by a longitudinal slit or } \\
\text { irregular split at central area of } \\
\text { cover }\end{array}$ & $\begin{array}{l}\text { Ectal excipulum dark } \\
\text { coloured textura angularis } \\
\text { cells, medullary } \\
\text { excipulum light coloured } \\
\text { textura angularis cells }\end{array}$ & $\begin{array}{l}\text { Filiform, often } \\
\text { branched at the tip }\end{array}$ & $\begin{array}{l}\text { 8-spored, cylindric- } \\
\text { clavate, non-amyloid }\end{array}$ & $\begin{array}{l}\text { Hyaline, elliptical to } \\
\text { obviate, } 3 \text {-septate }\end{array}$ \\
\hline \multicolumn{6}{|c|}{ Neocrinulaceae clade } \\
\hline Neocrinulaceae & Sexual morphs are not recorded & - & - & - & - \\
\hline \multicolumn{6}{|l|}{ Phacidiales } \\
\hline Phacidiaceae & $\begin{array}{l}\text { Apothecial, discoid to cupulate, } \\
\text { immersed, usually open by } \\
\text { splitting into teeth or lobes with } \\
\text { adhering host tissue }\end{array}$ & $\begin{array}{l}\text { Ectal excipulum textura } \\
\text { angularis cells, medullary } \\
\text { excipulum is unclear or } \\
\text { very thin }\end{array}$ & $\begin{array}{l}\text { Filiform, cylindric } \\
\text { or lanceolate, } \\
\text { sometimes apically } \\
\text { curled }\end{array}$ & $\begin{array}{l}4-8 \text {-spored, } \\
\text { cylindric-clavate, } \\
\text { mostly amyloid, } \\
\text { arising from croziers }\end{array}$ & $\begin{array}{l}\text { Ellipsoid, fusoid or } \\
\text { cylindric-clavate, } \\
\text { hyaline, aseptate, } \\
\text { guttulate }\end{array}$ \\
\hline \multicolumn{6}{|l|}{ Rhytismatales } \\
\hline Calloriaceae & $\begin{array}{l}\text { Apothecial, cupulate } \\
\text { rounded to elongated }\end{array}$ & $\begin{array}{l}\text { Ectal excipulum textura } \\
\text { prismatica or angularis to } \\
\text { globulosa cells, medullary } \\
\text { excipulum } \\
\text { prismatica to porrecta } \\
\text { cells }\end{array}$ & $\begin{array}{l}\text { Filiform or } \\
\text { lanceolate, apically } \\
\text { slightly swollen, } \\
\text { straight or flexuous, } \\
\text { sometimes guttulate }\end{array}$ & $\begin{array}{l}\text { 8-spored, non- } \\
\text { amyloid or amyloid, } \\
\text { sometimes arising } \\
\text { from croziers }\end{array}$ & $\begin{array}{l}\text { Ellipsoid to fusoid, } 0 \\
\text { 3-sepatate, guttulate }\end{array}$ \\
\hline Pezizellaceae & $\begin{array}{l}\text { Apothecial, discoid to cupulate, } \\
\text { sessile or stipitate, sometimes } \\
\text { covered by hairs }\end{array}$ & $\begin{array}{l}\text { Ectal excipulum reduced } \\
\text { or textura angularis, } \\
\text { prismatica or oblita cells, } \\
\text { medullary excipulum } \\
\text { textura intricata }\end{array}$ & $\begin{array}{lr}\text { Filiform } & \text { or } \\
\text { lanceolate, } & \text { septate } \\
\text { or aseptate } & \end{array}$ & $\begin{array}{l}\text { 4-8-spored, amyloid } \\
\text { or non-amyloid, } \\
\text { cylindric-clavate, } \\
\text { sometimes arising } \\
\text { from croziers }\end{array}$ & $\begin{array}{l}\text { Ellipsoid, allantoid to } \\
\text { fusoid, } \\
\text { guttulate }\end{array}$ \\
\hline
\end{tabular}


Table 2 Continued.

\begin{tabular}{|c|c|c|c|c|c|}
\hline Family & Ascomata & Excipulum/ Peridium & Paraphyses & Asci & Ascospores \\
\hline \multicolumn{6}{|l|}{ Rhytismatales } \\
\hline Rhytismataceae & $\begin{array}{l}\text { Apothecial, long-stipitate, } \\
\text { clavate, capitate or spathulate } \\
\text { apothecia or sessile, erumpent, } \\
\text { circular, navicular or } \\
\text { hysteriform, clypeate and } \\
\text { opening by a longitudinal split } \\
\text { or radial fissure }\end{array}$ & $\begin{array}{l}\text { Ectal excipulum textura } \\
\text { angularis or textura } \\
\text { porrecta cells, medullary } \\
\text { excipulum reduced or } \\
\text { textura intricata to } \\
\text { prismatica cells }\end{array}$ & $\begin{array}{l}\text { Rarely absent, } \\
\text { filiform, mostly } \\
\text { aseptate, branched } \\
\text { or unbranched, } \\
\text { sometimes apically } \\
\text { slightly swollen } \\
\text { and strongly curved }\end{array}$ & $\begin{array}{l}\text { 4-8-spored, mostly } \\
\text { non-amyloid, } \\
\text { cylindric-clavate, } \\
\text { arising from croziers }\end{array}$ & $\begin{array}{l}\text { Ovoid, ellipsoid, } \\
\text { clavate, sub- } \\
\text { cylindrical, fusoid or } \\
\text { filiform, hyaline, } \\
\text { usually aseptate, apex } \\
\text { slightly curved, base } \\
\text { strongly tapered, } \\
\text { sometimes apex partly } \\
\text { covered by a gel cap }\end{array}$ \\
\hline \multicolumn{6}{|l|}{ "Sclerotiniales" } \\
\hline Cenangiaceae & $\begin{array}{l}\text { apothecial, cupulate to discoid, } \\
\text { sessile or short-stipitate }\end{array}$ & $\begin{array}{lr}\text { Ectal excipulum textura } \\
\text { angularis to globulosa } \\
\text { cells, } & \text { medullary } \\
\text { excipulum } & \text { textura } \\
\text { intricata cells } & \end{array}$ & $\begin{array}{l}\text { Filiform, septate, } \\
\text { slightly swollen at } \\
\text { the apex }\end{array}$ & $\begin{array}{l}\text { 8-spored, cylindric- } \\
\text { clavate, amyloid, } \\
\text { sometimes arising } \\
\text { from croziers }\end{array}$ & $\begin{array}{l}\text { Globose, ellipsoid to } \\
\text { fusoid, } 0 \text {-2-septate, } \\
\text { hyaline }\end{array}$ \\
\hline Chlorociboriaceae & $\begin{array}{l}\text { Apothecial, cupulate to discoid, } \\
\text { stipitate, arising from a basal } \\
\text { stromatic mass, erumpent or } \\
\text { superficial, blue green, exterior } \\
\text { surface glabrous or with short } \\
\text { septate hairs }\end{array}$ & $\begin{array}{l}\text { Ectal excipulum textura } \\
\text { prismatica or textura } \\
\text { intricata cells, medullary } \\
\text { excipulum textura } \\
\text { intricata cells }\end{array}$ & $\begin{array}{l}\text { Filiform, simple, } \\
\text { slightly branched }\end{array}$ & $\begin{array}{l}\text { 8-spored, arising } \\
\text { from croziers, } \\
\text { cylindric-clavate, } \\
\text { amyloid }\end{array}$ & $\begin{array}{l}\text { Ellipsoid to fusoid, } \\
\text { straight to slightly } \\
\text { curved, hyaline, 0-3- } \\
\text { septate }\end{array}$ \\
\hline Hemiphacidiaceae & $\begin{array}{l}\text { Apothecial, discoid to cupulate, } \\
\text { sessile or stipitate, sometimes } \\
\text { immersed in host tissue and } \\
\text { opening by a lid or transversal } \\
\text { cracks of the overlying host } \\
\text { tissue }\end{array}$ & $\begin{array}{l}\text { Ectal excipulum reduced } \\
\text { or textura globulosa- } \\
\text { angularis or prismatica } \\
\text { cells, } \\
\text { excipulum } \\
\text { angularis or intricata cells }\end{array}$ & $\begin{array}{l}\text { Cylindrical or } \\
\text { lanceolate, } \\
\text { sometimes slightly } \\
\text { swollen at the } \\
\text { apices }\end{array}$ & $\begin{array}{l}2-8 \text {-spored, amyloid } \\
\text { or non-amyloid, } \\
\text { sometimes arising } \\
\text { from croziers }\end{array}$ & $\begin{array}{l}\text { Ellipsoid, fusoid, } \\
\text { clavate or allantoid, 0- } \\
\text { 1-septate, hyaline or } \\
\text { brown, sometimes with } \\
\text { sheath }\end{array}$ \\
\hline $\begin{array}{l}\text { Neolauriomycetac } \\
\text { eae }\end{array}$ & Do not form Sexual morphs & - & - & - & - \\
\hline
\end{tabular}


Table 2 Continued.

\begin{tabular}{|c|c|c|c|c|c|}
\hline Family & Ascomata & Excipulum/ Peridium & Paraphyses & Asci & Ascospores \\
\hline \multicolumn{6}{|l|}{ "Sclerotiniales" } \\
\hline Rutstroemiaceae & $\begin{array}{l}\text { Apothecial or cleistothecial. } \\
\text { Apothecia cupulate to discoid, } \\
\text { stipitate. Cleistothecia sub- } \\
\text { globose }\end{array}$ & $\begin{array}{l}\text { Ectal excipulum textura } \\
\text { prismatica or textura } \\
\text { globulosa cells, medullary } \\
\text { excipulum rextura } \\
\text { intricata cells }\end{array}$ & Cylindrical & $\begin{array}{l}\text { 8-spored, cylindric- } \\
\text { clavate, amyloid, } \\
\text { rarely non-amyloid, } \\
\text { sometimes arising } \\
\text { from croziers }\end{array}$ & $\begin{array}{l}\text { Ellipsoid to allantoid, } \\
\text { hyaline, } 0-4 \text {-septate }\end{array}$ \\
\hline Sclerotiniaceae & $\begin{array}{l}\text { Apothecial, cupulate to plane } \\
\text { or pileate, stipitate, usually } \\
\text { emerge from sclerotia }\end{array}$ & $\begin{array}{l}\text { Ectal excipulum textura } \\
\text { globulosa or prismatica } \\
\text { cells, } \\
\text { excipulum medullary } \\
\text { prismatica, intricata cells } \\
\text { or loosely arranged } \\
\text { hyphae }\end{array}$ & $\begin{array}{l}\text { Filiform, } \\
\text { cylindrical, hyaline }\end{array}$ & $\begin{array}{l}2-8 \text {-spored, amyloid, } \\
\text { rarely non-amyloid, } \\
\text { sometimes arising } \\
\text { from croziers }\end{array}$ & $\begin{array}{l}\text { Ellipsoid, rarely fusoid } \\
\text { or allantoid, smooth, } \\
\text { hyaline, rarely warted, } \\
\text { guttulate, often with } \\
\text { sheath, 1-3-septate and } \\
\text { budding microconidia }\end{array}$ \\
\hline \multicolumn{6}{|l|}{ Thelebolales } \\
\hline Thelebolaceae & $\begin{array}{l}\text { Ascomata absent, apothecial or } \\
\text { cleistothecial. When ascomata } \\
\text { absent, asci formed directly on } \\
\text { fertile hyphae. Apothecia } \\
\text { turbinate, } \\
\text { obconical, pulvinate, or } \\
\text { cupulate, sessile or sub- } \\
\text { stipitate, glabrous or with thin- } \\
\text { walled, tapering hairs. }\end{array}$ & $\begin{array}{l}\text { Without an exciple or } \\
\text { peridium, when present } \\
\text { ectal excipulum textura } \\
\text { globulosa-angularis, } \\
\text { prismatica or textura } \\
\text { porrecta cells, medullary } \\
\text { excipulum textura } \\
\text { porrecta, prismatica cells } \\
\text { or loosely arranged } \\
\text { hyphae, peridium textura } \\
\text { globulosa-angularis cells }\end{array}$ & $\begin{array}{l}\text { Absent or when } \\
\text { present filiform, } \\
\text { sometimes apically } \\
\text { swollen, straight to } \\
\text { slightly curved, } \\
\text { septate }\end{array}$ & $\begin{array}{l}4-1000 \text {-spored, } \\
\text { ellipsoidal clavate to } \\
\text { subglobose or } \\
\text { broadly cylindrical, } \\
\text { sessile, sometimes } \\
\text { arising from croziers, } \\
\text { non-amyloid, or } \\
\text { evanescent } \\
\text { opening by rupturing } \\
\text { or operculate }\end{array}$ & $\begin{array}{l}\text { Ellipsoid, fusoid to } \\
\text { filiform, globose to } \\
\text { ellipsoid or lunate, } \\
\text { hyaline or brown, } \\
\text { aseptate, rarely septate, } \\
\text { sometimes guttulate, } \\
\text { smooth-walled or } \\
\text { ornamented, aseptate }\end{array}$ \\
\hline $\begin{array}{l}\text { Alatospora- } \\
\text { Miniancora clade }\end{array}$ & Sexual morphs are not recorded & - & - & - & - \\
\hline Triblidiales & & & & & \\
\hline Triblidiaceae & $\begin{array}{l}\text { Apothecial, discoid or } \\
\text { hysterioid, sessile or sub- } \\
\text { stipitate, closed at immature } \\
\text { stage and open by a split or } \\
\text { radial fissure }\end{array}$ & $\begin{array}{l}\text { Ectal excipulum textura } \\
\text { angularis cells }\end{array}$ & $\begin{array}{l}\text { Apically slightly } \\
\text { swollen, branched, } \\
\text { hyaline, guttulate }\end{array}$ & $\begin{array}{l}\text { 4-8-spored, } \\
\text { cylindric-clavate, } \\
\text { non-amyloid, arising } \\
\text { from croziers }\end{array}$ & $\begin{array}{l}\text { Ellipsoid to fusiform, } \\
\text { dictyo- } \\
\text { phragmosporous or } \\
\text { muriform, thick- } \\
\text { walled, smooth or } \\
\text { warted, multiguttulate }\end{array}$ \\
\hline
\end{tabular}


Table 2 Continued.

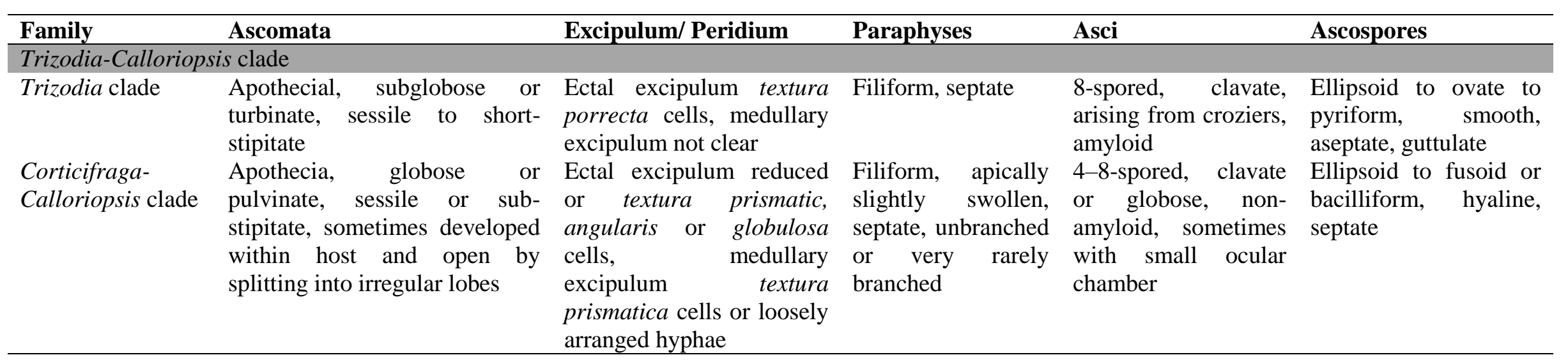

According to our phylogenetic analysis Leotiomycetes include 19 orders/order-level clades. Two additional orders are classified under Leotiomycetes order as incertae sedis based on morphological characteristics. The outline of all the genera and the families/family-level clades within Leotiomycetes are summarised in Table 1.

In this section we also provide short notes on each order/order-level clade and give a brief discussion on each family/family-level clade. This section also includes a table that summarizes the major sexual morph characteristics of Leotiomycetes families (Table 2).

Our collection includes members of the families Cordieritidaceae, Chlorociboriaceae, Helotiaceae, Lachnaceae, Calloriaceae, Loramycetaceae, Ploettnerulaceae, Vibrisseaceae, Dermateaceae, Leptodontidiaceae, Phacidiaceae, Rhytismataceae and Pezizellaceae. Morphological plates and detailed description with small scale phylogenetic analyses are provided for new collections.

\section{CHAETOMELLALES}

This order was introduced by Crous et al. (2017) and included a single family Chaetomellaceae. According to our phylogenetic analysis and a previous study (Pärtel 2016), we place Marthamycetaceae and Corticifraga-Calloriopsis clade under this order.

\section{Chaetomellaceae Baral, P.R. Johnst. \& Rossman}

Facesoffungi number: FoF 05850

This family includes mainly plant pathogens or saprobes. Sexual morphs are not common. Ascomata are apothecial, sessile to substipitate, erumpent and initially developing beneath the epidermis and sometimes are covered by hairs or setae. Setae are cylindrical, apically subclavate, straight or sometimes strongly curled, smooth and thick-walled and septate. The ectal excipulum is composed of cells of textura angularis to globulosa or textura prismatica to porrecta and medullary excipulum is composed of textura prismatica to porrecta. Paraphyses are filiform and apically branched. 
Asci are cylindric-clavate, 8-spored, non-amyloid and arising from croziers and ascospores are hyaline, ellipsoid to fusoid and aseptate (Pärtel et al. 2017, Jaklitsch et al. 2016). Asexual morphs are two synanamorphs. They are pycnidial and sporodochial. Pycnidia are brown to black, subglobose and walls are composed of cells of textura angularis and sporodochia are sessile to long-stalked and externally ochraceous to brown. Both conidiomata types of Chaetomellaceae are covered with smooth and scattered brown setae. Conidiogenesis is phialidic and conidia are cylindrical to sometimes ellipsoidal, straight to curved, often with pointed ends and 0-1-septate (Decock et al. 2005, Verkley 2001, 2002, Fiuza et al. 2015, Pärtel et al. 2017, Oliveira et al. 2014).

Notes - Most of the taxa included in this family are asexual morphs (Decock et al. 2005, Verkley 2001, 2002, Rossman et al. 2004, Fiuza et al. 2015). When both asexual and sexual morphs present, they are often covered with setae (Jaklitsch et al. 2016). Some of the Chaetomellaceae are weak parasites, which cause leaf spot disease and also attack fruits (Johnston et al. 2014).

Marthamycetaceae Baral, Lantz, Hustad et al.

Facesoffungi number: FoF 05851

Taxa of this family are saprobic on dead plant material or rarely pathogenic (DiCosmo et al. 1983, Giordano \& Gonthier 2011, Raymundo et al. 2016). They are mainly distributed in tropical and subtropical regions (Johnston 2006, Raymundo et al. 2016). Ascomata are apothecial and mainly characterised by rounded to elongated receptacles. Apothecia are semi-immersed and the epihymenium splits into irregular lobes or to a median longitudinal split. The hymenium is white, cream or blue-green-grey, rarely yellow or orange-rose and sometimes covered by a clypeus. The ectal excipulum is mostly reduced and sometimes composed of hyaline to dark brown textura angularis or oblita and the medullary excipulum is composed of cells of textura oblita. The interscal tissue is composed of both densely septate, frequently anastomosing, filiform, branched paraphyses and periphysiods. Asci are cylindrical to sub-cylindrical or clavate, mostly 8-spored and rarely multi-spored, the apex is rounded or conical, non-amyloid or rarely with an amyloid ring and arise from croziers. Ascospores are ellipsoid to cylindrical or filiform, septate, straight or curved, sometimes muriform, hyaline and sometimes covered with gelatinous sheath or gelatinous caps at each end (Hunter et al. 2016, DiCosmo et al. 1983, Johnston 2006, Raymundo et al. 2016, Jaklitsch et al. 2016). Asexual morphs are mainly unknown (Jaklitsch et al. 2016).

Notes - This family was previously classified in Rhytismatales based on its morphology (Jaklitsch et al. 2016). However, Jaklitsch et al. (2016) opined that the family does not phylogenetically relate to Rhytismataceae. Hustad \& Miller (2011) and Lantz et al. (2011) showed its basal position within Leotiomycetes. In the phylogenetic analysis of Pärtel (2016), this family formed a monophyletic clade with Cheatomellaceae. Similarly, in our analysis it formed a basal clade, sister to Cheatomellaceae. Therefore, we place this family under the order Chaetomellales.

\section{CYTTARIALES}

This order introduced by Gamundí (1971) to accommodate the single family Cyttariaceae. In our phylogenetic analysis we observed a close relationship of Cordieritidaceae and Deltopyxidaceae within Cyttariales.

\section{Cyttariaceae Speg.}

Facesoffungi number: FoF 05852

This family includes obligate pathogens on Nothofagus spp. (Peterson \& Pfister 2010). Ascomata are pitted apothecia immersed in a sterile fleshy-gelatinous stroma. Apothecia are characterised by simple filiform paraphyses, 8-spored, inoperculate and amyloid asci and uninucleate, subglobose to ovoid, smooth to rugulose ascospores, which are hyaline to yellowish at first, but later becoming pigmented (Mengoni 1986, Peterson et al. 2010). Asexual morphs are pycnidial, immersed, conidiogenous cells are monoblastic and conidia are small, hyaline and aseptate. 
Notes - The family Cyttariaceae is host specific on Nothofagus spp. (and the segregate genera) and geographically restricted to southern South America (Argentina and Chile) and southeastern Australasia and including Tasmania, and New Zealand (Peterson \& Pfister 2010). This family is distinct from other Leotiomycetes taxa by producing compound apothecia, which have numerous apothecial cavities in a pear-shaped stroma (Peterson \& Pfister 2010).

Deltopyxidaceae Ekanayaka \& K.D. Hyde, fam. nov.

Index Fungorum number: IF556270; Facesoffungi number: FoF 05853

Type genus - Deltopyxis

Saprobic on dead plant material or lichenicolous. Sexual morph: Ascomata apothecial cupulate to discoid, sessile to substipitate. Margins more or less distinct or crenulate, pustulate. Ectal excipulum composed of cells of textura prismatica globulosa-angularis. Medullary excipulum composed of slightly gelatinized cells of textura globulosa-angularis-prismatica. Paraphyses filiform, clavate-capitate, sometimes apically slightly swollen and covered with gell sheath, septate, branched or unbranched. Asci 8-64 spored, clavate or sub-cylindrical, non-amyloid, opening by a large slit-like pore, arising from croziers. Ascospores ellipsoid to ovoid or slightly to strongly triangular, guttulate, budding to form cylindrical to ellipsoid phialoconidia. Asexual morphs: Conidiomata pycnidial, peridium composed of light brown cells of textura globulosa. Conidiophores subglobose to obpyriform, with a short to long neck. Conidiogenesis phialidic. Conidia rod-shaped, straight to slightly curved, eguttulate.

Notes - The family contains the two genera, Phaeopyxis with five species and Deltopyxis with a single species (Baral \& Marson 2012). These genera were formerly classified under Helotiales genera incertae sedis. In our phylogenetic analysis this new family formed a monophyletic clade sister to Cordieritidaceae with the strong statistical support (93\%-MLBP and 1- BYPP) (Fig. 1). However, the sister relationship is not statistically supported.

\section{Cordieritidaceae (Sacc.) Sacc.}

Facesoffungi number: FoF 05854

Taxa are saprobic on dead plant material or lichenicolous (Pérez-Ortega et al. 2011, Kocourková \& Knudsen 2009, Baral \& Marson 2001, Ertz \& Diederich 2006, Huhtinen \& Spooner 2005, Pärtel et al. 2017). Ascomata are apothecial. Apothecia are discoid, cupulate, funnel-shaped or ear-shaped, sessile or stipitate and sometimes arising from common base or from branched stipes and with a dark stroma. The margins and flanks are sometimes covered with hairs. Hairs are cylindrical, straight or curved with tapered and hooked apices, sometimes septate, hyaline or brownish and smooth or thick-walled. The ectal excipulum is composed of pigmented cells of textura globulosa-angularis or textura prismatica-intricata and medullary excipulum is composed of cells of textura prismatica-intricata or textura epidermoidea. Paraphyses are cylindrical or clavate, sometimes lanceolate, apically slightly swollen and gelatinized and septate. Asci are 8spored, non-amyloid and arising from croziers. Ascospores are ellipsoid to fusoid or rod-shaped, straight or sometimes curved, hyaline or olivaceous-brown and 0-3-septate (Diederich et al. 2010, Matocec et al. 2005, Pérez-Ortega et al. 2011, Kocourková \& Knudsen 2009, Baral \& Marson 2001, Ertz \& Diederich 2006, Jaklitsch et al. 2016, Huhtinen \& Spooner 2005, Pärtel et al. 2017, Diederich \& Coppins 2014, Etayo et al. 2015, Diederich \& Etayo 2000, 2004). Asexual morphs are coelomycetous, stromatic, multilocular, phialidic and holoblastic. Conidia are ellipsoid or triangular and hyaline to dark brown (Jaklitsch et al. 2016, Diederich \& Coppins 2014).

Notes - Considering the unique ionomidotic reaction (solubility of excipular pigments in $\mathrm{KOH})$ of most Cordieritidaceae taxa, Jaklitsch et al. (2016) suggested a separate phylogenetic position away from other Helotiales. In our phylogeny this family grouped within Cyttariales.

Unguiculella globosa Ekanayaka \& K.D. Hyde, sp. nov.

Index Fungorum number: IF556271; Facesoffungi number: FoF 05855; Fig. 4.

Etymology - refers to the globose ascospores 
Holotype - MFLU 18-1816

Saprobic on dead stems. Sexual morph: Apothecia 300-700 $\times 160-200 \mu \mathrm{m}$, arising singly, sessile, slightly erumpent, yellowish white. Receptacle cupulate. Disc concave. Hairs 14-18 × 2.5$4 \mu \mathrm{m}(\bar{x}=16.3 \times 2.8 \mu \mathrm{m}, \mathrm{n}=30)$ cylindric with curved acute tips, septate, walls usually thin, hyaline. Ectal excipulum $25-35 \mu \mathrm{m}(\bar{x}=27.8 \mu \mathrm{m}, \mathrm{n}=10)$ in lower flanks, composed of thinwalled, light brown to hyaline cells of textura angularis to prismatica. Medullary excipulum 70-80 $\mu \mathrm{m}(\bar{x}=77.6 \mu \mathrm{m}, \mathrm{n}=10)$ in lower flanks, composed of thin-walled, hyaline cells of textura epidermoidea. Hymenium hyaline. Paraphyses $1.8-2.2 \mu \mathrm{m}$ wide $(\bar{x}=2.1 \mu \mathrm{m}, \mathrm{n}=20)$, numerous, filiform, obtuse at the apex, septate, not exceeding the asci in length, smooth, guttulate. Asci 36-54 $\times 4-6.5 \mu \mathrm{m}(\bar{x}=45 \times 5 \mu \mathrm{m}, \mathrm{n}=30), 8$-spored, unitunicate, cylindrical, obtuse at the apex, nonamyloid, stipitate base, arising from croziers. Ascospores 3-4 $\mu \mathrm{m}(\bar{x}=3.6 \mu \mathrm{m}, \mathrm{n}=40)$ diam., 1 seriate, globose, hyaline, guttulate. Asexual morph: Undetermined.

Material examined - China, Yunnan Province, Kunming, Kunming Institute of Botany, Botanical Garden, 14 April 2016, A.H. Ekanayaka, HC03 (MFLU 18-1816).

GenBank accessions - LSU- MK591972, ITS- MK584946, SSU- MK585044, TEFMK714027, RPB2- MK614727

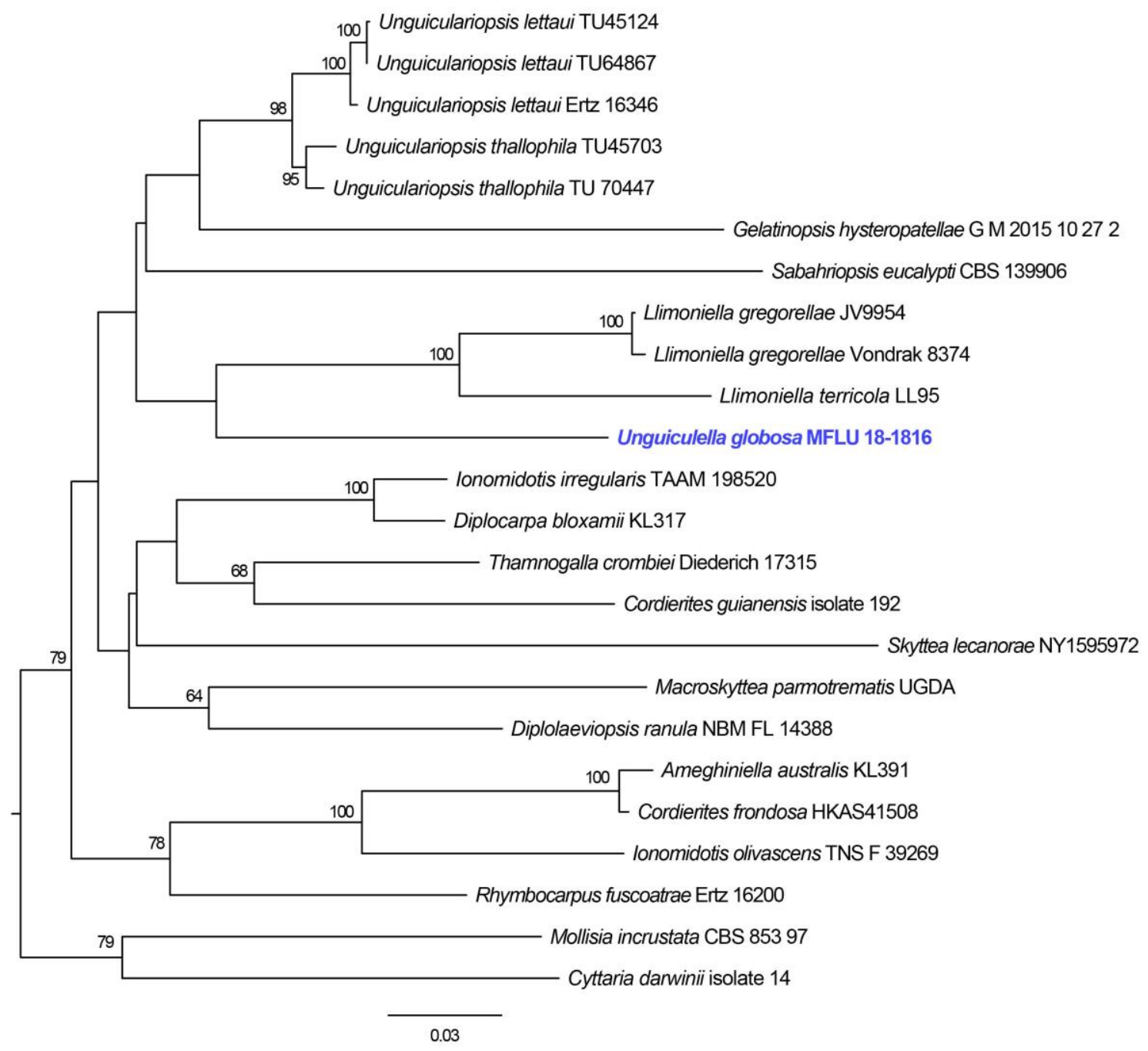

Figure 3 - Phylogram generated from maximum likelihood analysis of sequences of Cordieritidaceae based on ITS, LSU, SSU sequence data. MLBP values $\geq 50 \%$ are given near the nodes. Strain/culture numbers are given after the taxon names. The tree is rooted with Mollisia incrustata (CBS 853 97) and Cyttaria darwinii (isolate 14).

Notes - According to the phylogenetic analysis of Cordieritidaceae (Fig. 3), our new collection from China formed a branch sister to Llimoniella clade but with poor statistical support 
(MLBP-41\%). The SSU region of our collection shows similarity to that of Unguiculariopsis lettaui (TU64867) (971/1003-97\% with 3 gaps) from Estonia. The LSU region of our collection is similar to that of Unguiculariopsis thallophila (Diederich 16944) (790/864-91\% with 2 gaps) from Luxembourg.

Our collection also shows similarities to the genus Unguiculella (Spooner 1987, Huhtinen \& Spooner 2005). Unguiculella species are characterized by curved hairs. Similar morphology can be observed in the genera Hamalocanlhoscypha and Unguiculariopsis, which are phylogenetically related to Cordieritidaceae (Fig. 3). However, the hairs of Unguiculariopsis are slightly thicker (Spooner 1987) and those in Hamalocanlhoscypha have blunt apices (Matocec et al. 2005).

Unguiculella globosa is characterized by cupulate, yellowish white apothecia, hairs with curved acute tips, cylindric, septate paraphyses, cylindric-clavate asci and, globose ascospores. It is similar to U. tityrii, however, U. tityrii has ellipsoid ascospores (Huhtinen \& Spooner 2005). This is the first molecular data for the genus Unguiculella.

\section{ERYSIPHALES}

This order was introduced by Warming (1884) to accommodate the single family Erysiphaceae. In our analysis Erysiphaceae and Amorphothecaceae formed a monophyletic clade sister to Cyttariales. Both Erysiphaceae and Amorphothecaceae produce cleistothecial ascomata.

Erysiphaceae Tul. \& C. Tul.

Facesoffungi number: FoF 05856

Members of this family are obligate biotrophic parasites of vascular plants (Takamatsu 2004, Takamatsu et al. 2015). Ascomata are cleistothecial. Cleistothecia are chasmothecial, globose and solitary or aggregated. The peridium is thin-layered and composed of cells of textura angularis with appendages. The interscal tissue is absent. Asci are globose to broadly clavate, bitunicate but apically unitunicate, 2- to 8-spored and ascospores released by rupturing at the apices. Ascospores are aseptate, subglobose to ellipsoid, hyaline to yellowish and without a sheath (Braun 1981, Jones et al. 2014, Jaklitsch et al. 2016). Asexual morphs are hyphomycetous. Conidiophores arise from superficial hyphae. Conidia mature singly or in chains and are basipetal, aseptate, hyaline, thinwalled and ellipsoid to fusoid (Braun 1981, Jaklitsch et al. 2016).

Notes - This family differs from other Leotiomycetes (except Amorphothecaceae) mainly by producing cleistothecial ascomata and bitunicate but apically unitunicate asci (Braun 1981, Jaklitsch et al. 2016). Furthermore, this family includes obligate biotrophic parasites of vascular plants. They cause the diseases, powdery mildews on aerial parts such as leaves, shoots and stems and fruits and cannot be cultured on artificial media (Takamatsu et al. 2015, Sharifi et al. 2014, Glawe 2006). Erysiphaceae taxa cause considerable damage to many crop plants including Grapevine, Eucalyptus, Rubber, cucumber, tomato, onion, pepper and potato (Glawe 2006, Sharifi et al. 2014, Jones et al. 2014, Cho et al. 2018, Liyanage et al. 2017).

\section{Amorphothecaceae Parbery}

= Myxotrichaceae Locq. ex Currah

Facesoffungi number: FoF 05857

Taxa are saprobic on dead wood in terrestrial habitats or rarely lichenicolous (Tsuneda \& Currah 2004, Huhtinen \& Santesson 1997). Ascomata are cleistothecial or rarely apothecial (Tsuneda \& Currah 2004, Huhtinen \& Santesson 1997). Cleistothecia are characterized by globose, sometimes funnel-shaped apical outgrowths. The peridium is composed of thick-walled brown hyphae with appendages. Asci are 8-spored, sub-clavate to globose, arising from croziers and sometimes evanescent. Ascospores are hyaline, fusoid, ellipsoid, navicular or lenticular and with smooth or striate walls (Tsuneda \& Currah 2004). Apothecia are sessile and characterized by cupulate-turbinate receptacle. The flanks and margins are covered with hairs. The ectal excipulum is composed of cells of textura angularis. Paraphyses are filiform and branched at the apices. Asci are 8-spored, cylindric-clavate and amyloid. Ascospores are hyaline, ellipsoid to fusoid and 1-3- 
septate (Huhtinen \& Santesson 1997, Verkley 2005). Asexual morphs are hyphomycetous or sporodochial, dendritic arthroconidial and acropetal-blastic. Conidia dehisce rhexolytically, arise in chains or solitary on conidiogenous cells, globose, ellipsoid, fusoid or cylindrical, 0-4-septate, hyaline or brown and smooth-walled (Arx 1971, Tsuneda \& Currah 2004, Seifert et al. 2007, Huhtinen \& Santesson 1997, Verkley 2005, Calduch et al. 2004).

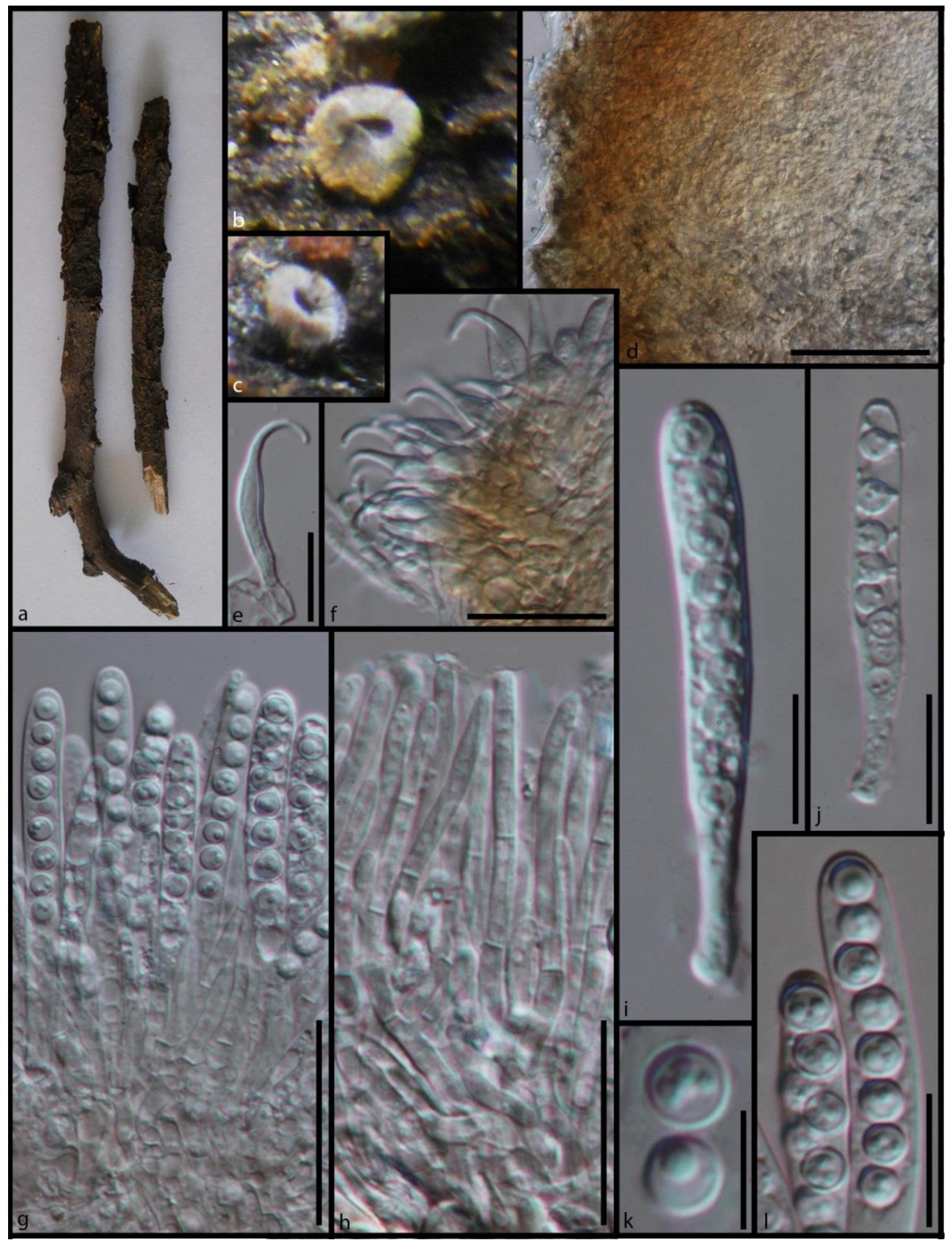

Figure 4 - Morphology of Unguiculella globosa (MFLU 18-1816 holotype) a Substrate. b, c Apothecia on wood. d Part of the excipulum at lower flanks. e, f Apically curved hairs. g, i, j Cylindrical asci. h Septate paraphyses. k Globose ascospores. 1 Asci apex with ascospores. Scale bars: $\mathrm{d}=100 \mu \mathrm{m}, \mathrm{g}, \mathrm{h}=50 \mu \mathrm{m}, \mathrm{e}, \mathrm{f}=20 \mu \mathrm{m}, \mathrm{i}, \mathrm{j}, \mathrm{l}=10 \mu \mathrm{m}, \mathrm{k}=5 \mu \mathrm{m}$. 
Notes - Our phylogenetic analysis shows a close relationship of the families Myxotrichaceae and Amorphothecaceae. The same phylogenetic affinities of these families were also reported in Seifert et al. (2007). Therefore, considering the result of our phylogenetic analysis and previous literature, we synonymize Myxotrichaceae under the older name Amorphothecaceae.

\section{FLAGELLOSPORA CLADE}

The genus Flagellospora was introduced by Ingold (1942). This genus was previously classified in Nectriaceae (Sordariomycetes) (Jaklitsch et al. 2016) and later in Leotiales (Wijayawardene et al. 2018). However, some taxa of Flagellospora are related to Leotiomycetes (Baschien et al. 2013). In our study the generic type of Flagellospora, Flagellospora curvula (CBM13) formed a separate clade sister to Thelebolaceae and Tympanidaceae clades.

\section{Flagellospora clade}

Facesoffungi number: FoF 05858

Taxa are saprobic. Ascomata are perithecial and subglobose by shape with conspicuously papillate ostiole. The peridium is composed of cells of textura angularis. Paraphyses are filiform, cylindrical to capitate, straight, unbranched and densely septate. Asci are 8-spored and cylindrical. Ascospores are ellipsoid to fusiform, 1-septate, guttulate, smooth and hyaline (Ranzoni 1956). Asexual morphs are hyphomycetous. Conidiophores are branched and conidiogenesis is phialidic. Conidia are ellipsoid to cylindrical or sigmoid, hyaline and aseptate (Ranzoni 1956, Jooste \& Merwe 1990).

Notes - Flagellospora is an aquatic hyphomycetes genus. Most of the aquatic hyphomycetes grow sub-merged but sporulate aerially by conidiophores that extend to the surface of the water. However, Flagellospora grow and sporulate on completely submerged, decaying leaves and wood of various angiosperms and their conidia are released beneath the water surface (Ranzoni 1956).

Flagellospora is a polyphyletic genus (Baschien et al. 2013). According to the phylogenetic analysis provided by Baschien et al. (2013), some Flagellospra spp clustered within Thelebolaceae while some are in a separate clade sister to Thelebolaceae clade. To stabilize the phylogenetic placement of this genus further studies are required with a wider range of taxa.

\section{"HELICOGONIALES" CLADE}

The family Helicogoniaceae was introduced by Baral et al. (2015) and classified within Phacidiales. Our phylogeny revealed that Helicogoniaceae and Phacidiaceae are polyphyletic and both families form independent clades close to each other. Hence, we suggest that this could be a new order in the class Leotiomycetes. However, this requires further collections and more sequence data to stabilize the position of this clade within Leotiomycetes.

\section{Helicogoniaceae Baral}

Facesoffungi number: FoF 05859

Taxa are fungicolous, lichenicolous or saprobic and mainly found in temperate regions. Some taxa in this family do not form ascomata, such as the genus Helicogonium which forms only naked asci on ascogenous hyphae. Some taxa (e.g. Gelatinipulvinella, Geltingia) form apothecial ascomata which are characterised by semi-globose to pulvinate receptacle, gelatinous ectal excipulum is composed of cells of textura prismatica to angularis to porrecta and with unclear medullary excipulum. Paraphyses are filiform. Asci are 8-spored, cylindric-clavate, amyloid or non-amyloid and opening by an apical slit. Ascospores are subglobose to ellipsoid to fusoid and they frequently form ascoconidia by budding. Asexual morphs are hyphomycetous or pycnidial. Conidia are ellipsoid to fusoid and sometimes with appendages (Alstrup \& Hawksworth 1990, Baral 1999, Baral \& Marson 2001, Cain 1948, Hosoya \& Otani 1995, White 1942, Suija et al. 2014, Adhikari et al. 2016).

Notes - Taxa of this family are distinct in producing much reduced ascomata and asci opening by a split (Jaklitsch et al. 2016). 


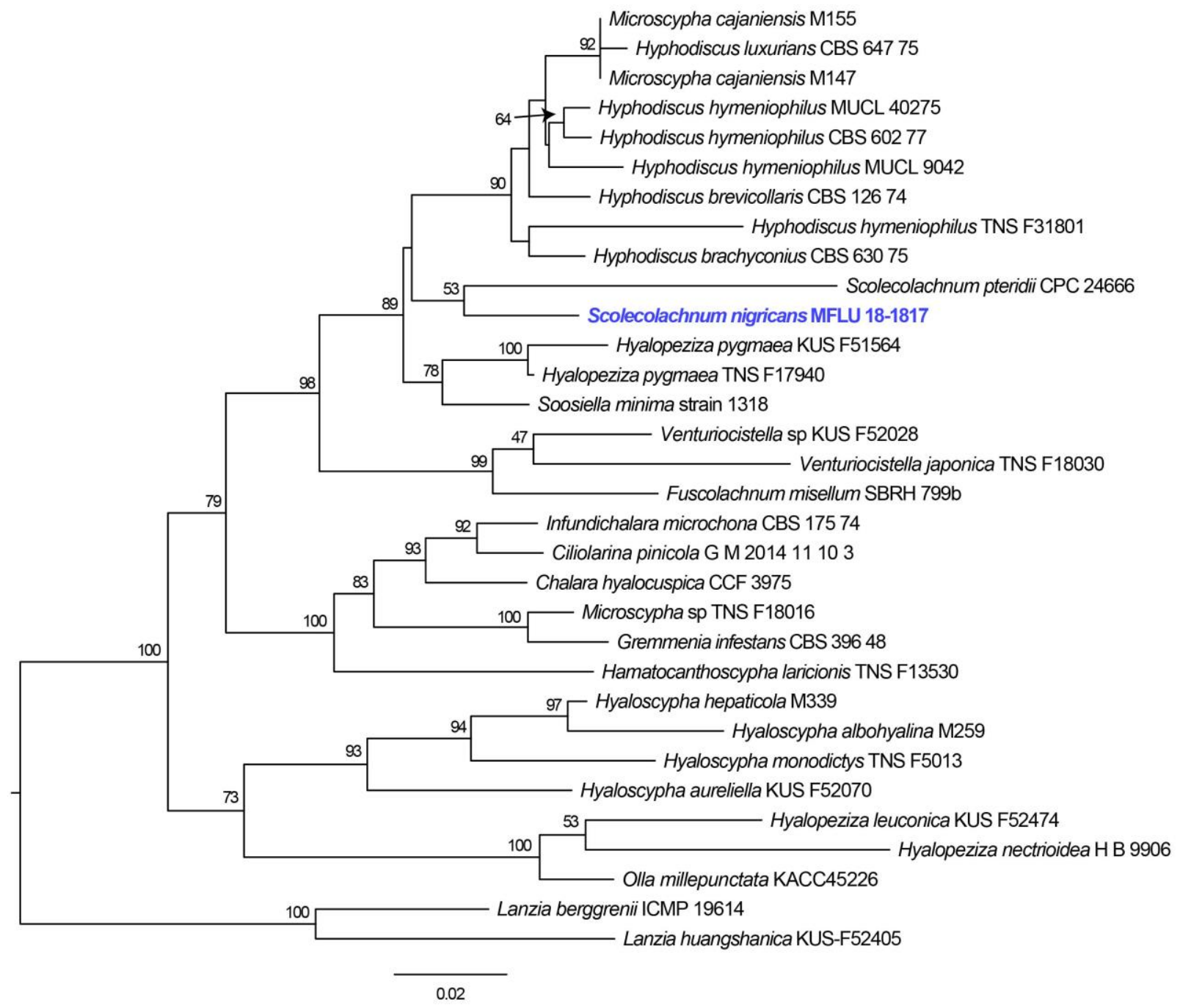

Figure 5 - Phylogram generated from maximum likelihood analysis of sequences of selected helotilian taxa based on ITS, LSU sequence data. MLBP values $\geq 50 \%$ are given near the nodes. Strain/culture numbers are given after the taxon names. The tree is rooted with Lanzia berggrenii (ICMP 19614) and Lanzia huangshanica (KUS-F52405).

\section{HAMATOCANTHOSCYPHA-HYPHODISCUS CLADE}

This clade includes two sub-clades previously regarded as helotilian taxa. It formed a monophyletic clade close to Medeolariales

Hyphodiscaceae Ekanayaka \& K.D. Hyde, fam. nov.

Index Fungorum number: IF556272; Facesoffungi number: FoF 05860

Type genus - Hyphodiscus

Saprobic on dead plant material. Sexual morphs: Ascomata apothecial, cupulate or discoid, sessile or short stalked, sometimes gelatinized. Margins covered with hairs. Hairs white or brownish, cylindrical, granulate, sometimes septate. Ectal excipulum composed cells of textura angularis, intricata or prismatica. Medullary excipulum composed of cells of textura intricata to angularis. Paraphyses hyaline, filiform, septate, slightly enlarged at the apices. Asci 8-spored, cylindric-clavate, amyloid or non-amyloid, sometimes arising from croziers. Ascospores hyaline, 0-3-septate, ellipsoid. Asexual morphs: Conidiomata hyphomycetous. Conidiophores borne on single or fasciculate hyphae. Conidiogenous cells phialidic. Conidia solitary, aseptate, subcylindrical to narrowly obovate, globose to turbinate or napiform, straight or slightly curved, hyaline. 
Notes - In our phylogenetic analysis we observed a close phylogenetic relationship of the genera Fuscolachnum, Hyalopeziza, Hyphodiscus, Scolecolachnum and Venturiocistella. These genera were previously classified within Hyaloscyphaceae and the asexual genus Soosiella (Hosoya et al. 2010, Pärtel \& Põldmaa 2011, Hujslová et al. 2014). They formed a monophyletic clade close to the family Hamatocanthoscyphaceae with statistical support of $69 \%$ (MLBP). Hujslová et al. (2014) reported the phylogenetic relationship of Soosiella, Hyphodiscus and Myxotrichaceae. Within the phylogenetic study of Guatimosim et al. (2016) Hyphodiscus and Scolecolachnum formed a well-supported monophyletic clade. By considering previous phylogenetic analyses and the phylogenetic placement in our analysis, we introduce the new family Hyphodiscaceae.

Scolecolachnum nigricans Ekanayaka \& K.D. Hyde, sp. nov.

Index Fungorum number: IF556273; Facesoffungi number: FoF 05861; Fig. 6.

Etymology - refers to the "blackish" apothecia

Holotype - MFLU 18-1817

Saprobic on dead stems. Sexual morph: Apothecia 250-300 × 150-200 $\mu \mathrm{m}$, arising singly, sessile, slightly erumpent. Receptacle cupulate, black. Disc concave, black. Hairs 50-65 × 4-5 $\mu \mathrm{m}$ $(\bar{x}=60 \times 4.5 \mu \mathrm{m}, \mathrm{n}=30)$ cylindric, without a lumen, aseptate, walls granulate, blackish brown. Ectal excipulum 10-20 $\mu \mathrm{m}(\bar{x}=16 \mu \mathrm{m}, \mathrm{n}=10)$ in lower flanks, composed of, thin-walled, light brown cells of textura prismatica. Medullary excipulum 30-40 $\mu \mathrm{m}(\bar{x}=36 \mu \mathrm{m}, \mathrm{n}=10)$ in lower flanks, composed of, thin-walled, hyaline cells of textura oblita. Hymenium hyaline. Paraphyses 2$3.5 \mu \mathrm{m}$ wide $(\bar{x}=2.5 \mu \mathrm{m}, \mathrm{n}=20)$, numerous, filiform, obtuse, aseptate, smooth, guttulate. Asci 50-60 $\times 10-15 \mu \mathrm{m}(\bar{x}=58.5 \times 12.5 \mu \mathrm{m}, \mathrm{n}=30)$ arising from croziers, 8-spored, unitunicate, cylindric-clavate, conical apex, amyloid, sub-stipitate base, arising from croziers. Ascospores 10$18 \times 2.5-3.5 \mu \mathrm{m}(\bar{x}=16 \times 3.1 \mu \mathrm{m}, \mathrm{n}=40), 1-2$-seriate, ellipsoid to fusoid, aseptate, hyaline, guttulate. Asexual morph: Undetermined.

Material examined - China, Yunnan Province, Kunming, Kunming Institute of Botany, Botanical Garden, 14 April 2016, A.H. Ekanayaka, HC06a (MFLU 18-1817).

GenBank accessions - LSU- MK591973, ITS- MK584975, SSU- MK585045

Notes - Our collection from China grouped sister to Scolecolachnum pteridii CPC 24666 from Brazil (Fig. 5), with poorly statistical support (53\%). The ITS region of our collection is similar to that of Hyalopeziza pygmaea (KUS-F51564) (523/561-91\% with 6 gaps), Hyphodiscus hymeniophilus (MUCL 40275) (465/498-93\% with 3 gaps) and Hyphodiscus brachyconius (CBS 630.75) (469/505-93\% with 4 gaps). The LSU region is similar to that of Hyaloscypha aureliella (KUS-F52070) (1029/1119-92\% with 18 gaps) and Hyphodiscus hymeniophilus (MUCL 40275) (997/1094-91\% with 26 gaps) and Hyphodiscus brachyconius (CBS 630.75) (990/1083-91\% with 24 gaps).

The genus Scolecolachnum previously included a single species Scolecolachnum pteridii and characterised by whitish apothecia with smooth, hyaline hairs, filiform paraphyses, sub-cylindrical asci and filiform ascospores. Our collection differs from Scolecolachnum pteridii by having blackish brown apothecia, granulate short hairs, asci with croziers and ellipsoid to fusoid ascospores (Guatimosim et al. 2016).

Our new species is similar to the genus Hyalopeziza, especially $H$. pygmaea and $H$. digitipila by having small cupulate, blackish apothecia, granulate hairs, filiform paraphyses, cylindric-clavate asci with croziers, ellipsoid to fusoid ascospores. However, our species differs from H. pygmaea by having longer asci and ascospores (Huhtinen 1987a, 2001, Hosoya \& Otani 1997) and from $H$. digitipila by not having stipitate apothecia and branched hairs (Huhtinen 1987a). 


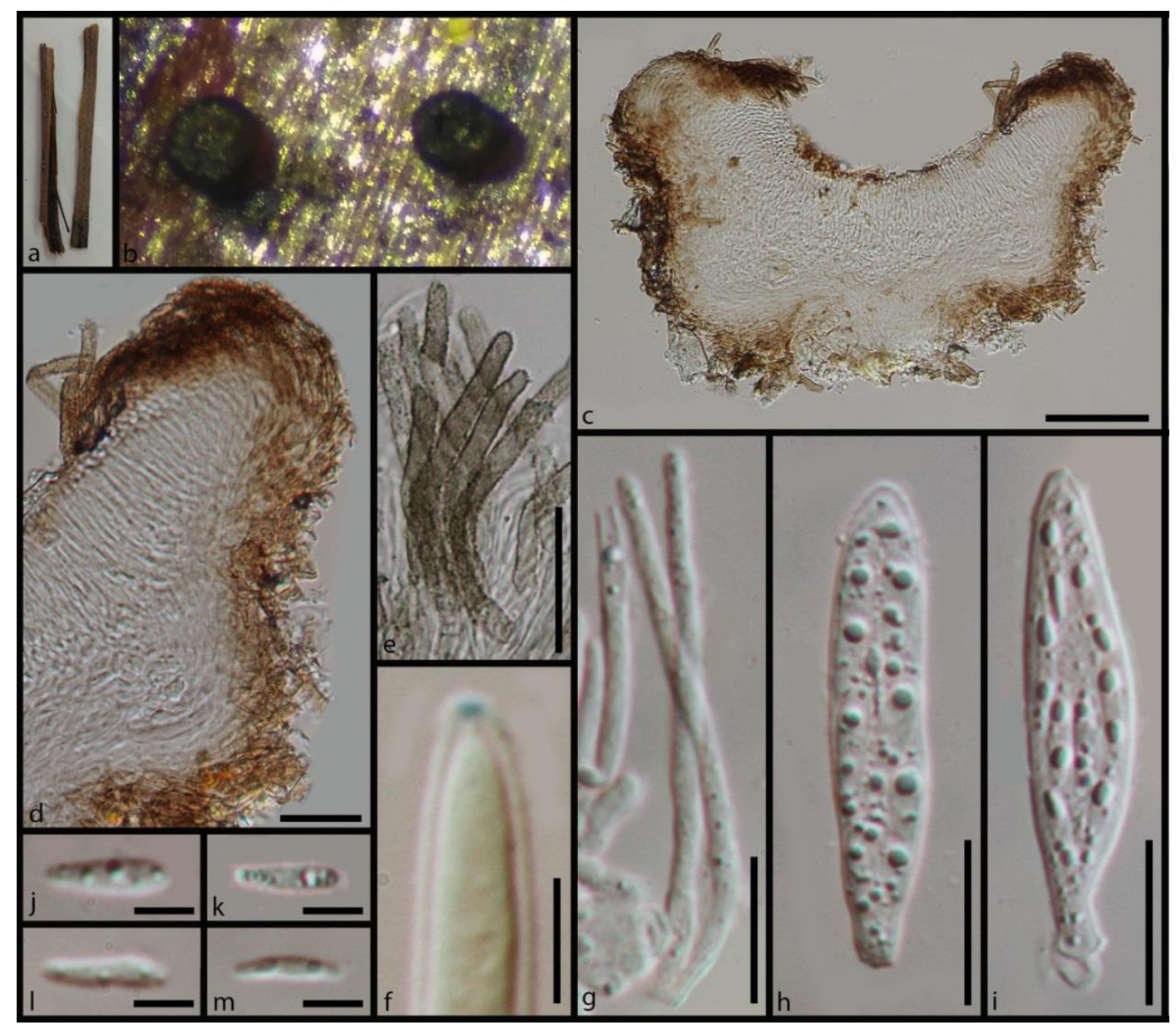

Figure 6 - Morphology of Scolecolachnum nigricans (MFLU 18-1817 holotype) a Substrate. b Rehydrated apothecia on wood. c Cross section of an apothecium. d Close up of the cross section of apothecium at margins. e Cylindrical hairs. f Amyloid ascus apex in Melzer's reagent. g Filiform paraphyses. h, i Cylindric-clavate asci. j-m Fusoid ascospores. Scale bars: $c=50 \mu \mathrm{m}, \mathrm{d}, \mathrm{e}=30 \mu \mathrm{m}$, $\mathrm{g}-\mathrm{i}=20 \mu \mathrm{m}, \mathrm{f}=10 \mu \mathrm{m}, \mathrm{j}-\mathrm{m}=5 \mu \mathrm{m}$.

Hamatocanthoscyphaceae Ekanayaka \& K.D. Hyde, fam. nov.

Index Fungorum number: IF556274; Facesoffungi number: FoF 05862

Type genus - Hamatocanthoscypha

Saprobic or parasitic. Sexual morphs: Ascomata apothecial, cupulate or discoid, sessile, rarely stipitate, erumpent. Ectal excipulum reduced or composed of cells of textura intricata or textura prismatica. Medullary excipulum composed of cells of textura intricata or textura prismatica, paraphyses, filiform, slightly swollen at the apices. Asci 8-spored, non-amyloid, cylindric-clavate, sometimes arising from croziers. Ascospores ellipsoid to fusoid, hyaline, 0-1septate. Asexual morphs: Conidiomata hyphomycetous, sporodochial. Conidiogenesis phialidic, proliferating sympodially. Conidia hyaline, ellipsoid, fusoid to cylindrical, 0-1-septate.

Notes - This family includes the genera previously classified under Phacidiaceae, Hyaloscyphaceae, Pezizellaceae and Helotiales genera incertae sedis (Kušan et al. 2014, Réblová et al. 2011, Koukol 2012, Wijayawardene et al. 2018). According to our phylogenetic analysis this family forms a separate clade sister to the Hyphodiscaceae.

In the phylogenetic analysis of Delgado et al. (2015) Hyalodendriella and Curviclavula grouped close to Hyaloscyphaceae, but in separate clades. Coetsee et al. (2000) showed that Xenochalara and Chalara are phylogenetically closely related. Genetic relatedness of the genera Bloxamia with Zymochalara and Chalara are reported by Hernandez-Restrepo et al. (2017) and Guatimosim et al. (2016). Within the phylogenetic analysis of Crous et al. (2014) Gremmenia was placed within Pezizellaceae even though it was classified in Phacidiaceae as reported in our study. 
Therefore, considering previous literature and our phylogenetic results, here we introduce the new family Hamatocanthoscyphaceae.

\section{HELOTIALES}

The order Helotiales was introduced by Nannfeldt (1932) to include fungi with cupulate apothecia covered by long cylindrical hairs. According to the previous classification system this is the largest order of Leotiomycetes and includes 27 families (Wijayawardene et al. 2018). However, according to our phylogenetic analysis this order includes 25 families/family-level clades. Previous studies (Wang et al. 2006a, b, Hustad \& Miller 2011, Pärtel 2016) also confirms its polyphyletic nature within Leotiomycetes.

\section{Arachnopezizaceae Hosoya, J.G. Han \& Baral}

Facesoffungi number: FoF 05863

Taxa are saprobic on dead plant material. Ascomata are apothecial and characterized by a receptacle covered by hairs. The hymenium is flat. The ectal excipulum is composed of cells of textura angularis to prismatica and medullary excipulum is composed of cells of textura prismatica to oblita. Paraphyses are cylindrical and hyaline. Asci are cylindric-clavate, amyloid, arising from croziers and 8-spored. The ascospores are 0-7-septate and ellipsoid to fusoid (Jaklitsch et al. 2016, Wang 2009, Korf 1951, 1952, Huhtinen 1985, Inman et al. 1992, Quijada et al. 2017). Asexual morphs are not recorded.

Notes - We observed the close phylogenetic relationship of the genera Durella and Unguicularia within Arachnopezizaceae as suggested by Jaklitsch et al. (2016). Therefore, considering our phylogenetic results and previous literature, here we placed those genera under Arachnopezizaceae.

\section{Drepanopezizaceae Bat. \& H. Maia}

Facesoffungi number: FoF 05864

Taxa are plant pathogenic (Dimova et al. 2014, Blechert \& Debener 2005, Samuels et al. 1981, Spiers \& Hopcroft 1998, Pearson et al. 1988). Ascomata are apothecial. Apothecia are cupulate, sessile and mostly immersed. The excipulum is a thin layer, composed of cells of textura angularis. Paraphyses are apically slightly swollen and straight. Asci are 4-8- spored, apex obtuse to conical and non-amyloid. Ascospores are ellipsoid to fusoid and aseptate or 1-2-septate (Samuels et al. 1981, Spiers \& Hopcroft 1998, Korf et al. 1986). Asexual morphs are hyphomycetous, acervulus. Conidiogenesis is holoblastic. Conidia are sometimes two types, macroconidia are ellipsoid to fusoid and slight curved and microconidia are sometimes present and ellipsoid to bacilliform (Konig et al. 2009, Yoshikawa \& Yokoyama 1992).

Notes - This is a highly plant pathogenic family within Leotiomycetes, which cause leaf spot, early defoliation, chlorosis and leaf and twig blight of various dicotyledons including poplars, leek, cherry, rose and grape (Dimova et al. 2014, Blechert \& Debener 2005, Samuels et al. 1981, Spiers \& Hopcroft 1998, Pearson et al. 1988, Lee et al. 2011, Rossman et al. 2018).

\section{Patellariopsis clade}

Facesoffungi number: FoF 05865

Taxa are saprobic on dead plant material. Ascomata are apothecial and characterised by discoid receptacle. The ectal excipulum is composed of thick-walled cells of textura globulosa to angularis and medullary excipulum is composed of interwoven refractive hyphae. Paraphyses are filiform, branched and pigmented at the apices. Asci 8-spored, cylindric-clavate and amyloid. Ascospores are ellipsoid to fusoid, hyaline and 3-7-septate (Dennis 1974, Beaton \& Weste 1978). Asexual morphs are hyphomycetous, periconia- like (Karunarathna et al. Pers comm).

Notes - The genus Patellariopsis was introduced by Dennis (1964) and currently includes five species. 
Loramycetaceae Dennis ex Digby \& Goos

Facesoffungi number: FoF 05866

Taxa are saprobic on dead plant material in fresh water habitats. Ascomata are apothecial or perithecial. The ectal excipulum is composed of cells of textura angularis, globulosa or prismatica embedded in an external gel and sometimes with vertically striate structures. The medullary excipulum is composed of cells of textura prismatica. Paraphyses are filiform, septate, unbranched, sometimes apically swollen and pigmented. Asci are cylindric-clavate, 8-spored and amyloid or non-amyloid. Ascospores are fusiform, septate and sometimes with terminal appendages and gel sheath (Ingold \& Chapman 1952, Digby \& Goos 1987). Asexual morphs are hyphomycetous and anguillospora-like. Conidiophores are simple or occasionally branched. Conidiogenous cells are hyaline and straight. Conidia are globose, sub-ellipsoid or sigmoid and hyaline (Walsh et al. 2014, Digby \& Goos 1987).

Notes - According to our phylogenetic analysis we observed a close relationship of the genus Acidomelania with this family (Fig. 1). The same phylogenetic placement of Acidomelania is showed in the phylogeny of Walsh et al. (2014). Therefore, here we placed this genus under the family Loramycetaceae.

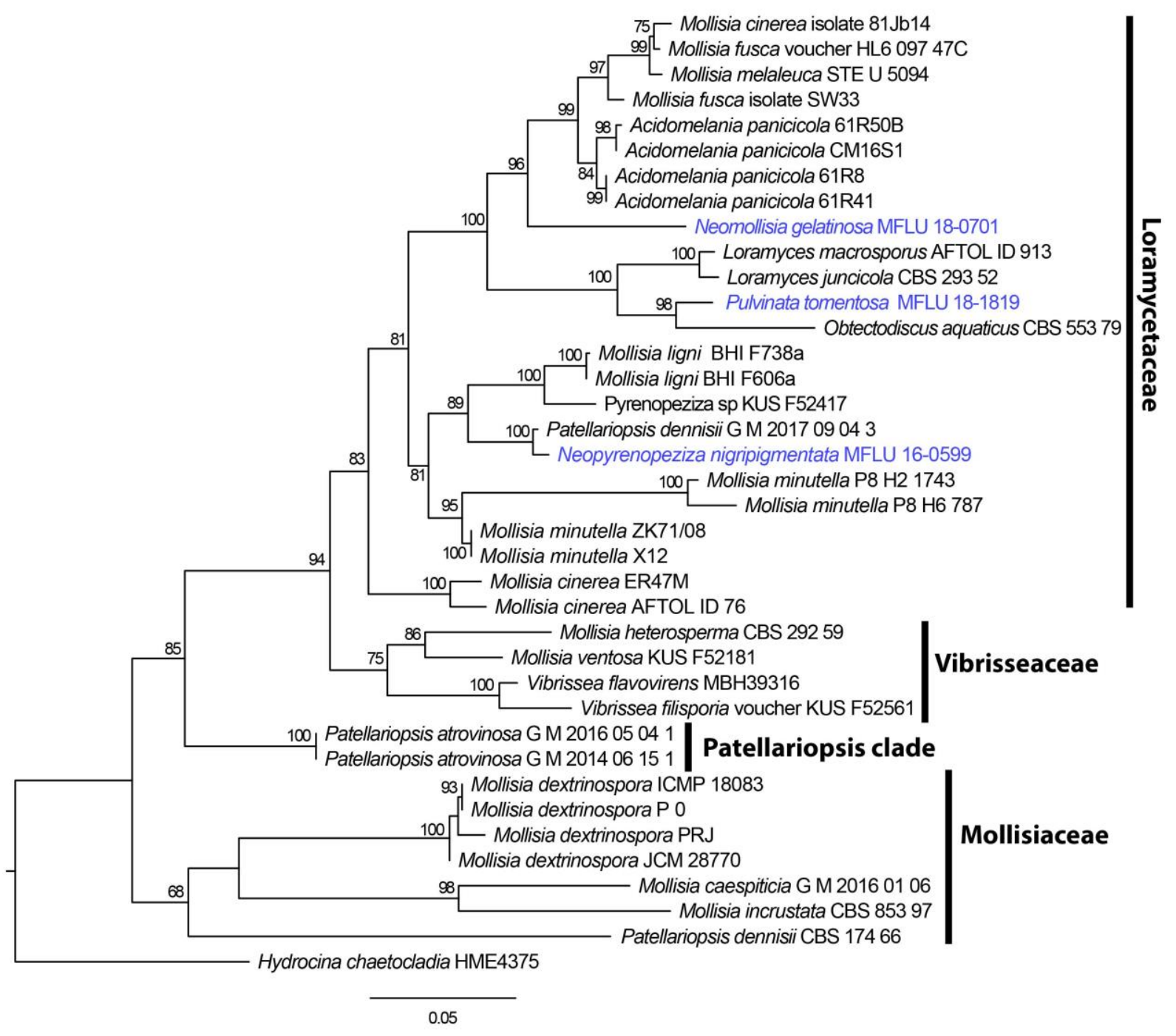

Figure 7 - Phylogram generated from maximum likelihood analysis of sequences of selected helotilian taxa based on ITS and LSU sequence data. MLBP values $\geq 50 \%$ are given near the nodes. Strain/culture numbers are given after the taxon names. The tree is rooted with Hydrocina chaetocladia (HME4375). 
Pulvinata Ekanayaka \& K.D. Hyde, gen. nov.

Index Fungorum number: IF556275; Facesoffungi number: FoF 05867

Etymology - refers to the shape of apothecia: Pulvinate

Saprobic on dead stems. Sexual morph: Apothecia arising singly, sessile, slightly erumpent. Receptacle pulvinate. Margins raised, whitish. Disc convex. Ectal excipulum composed of thinwalled, light brown to hyaline cells of textura angularis. Medullary excipulum composed of, thinwalled, hyaline cells of textura intricata. Hymenium hyaline. Paraphyses numerous, filiform, obtuse and slightly swollen at the apex, aseptate, not exceeding the asci in length, smooth, aguttulate. Asci 8-spored, unitunicate, cylindric-clavate, conical at the apex, amyloid ring present at the ascus apex, stipitate base, arising from croziers. Ascospores 1-2-seriate, ellipsoid to fusoid, aseptate, hyaline, guttulate. Asexual morph: Undetermined.

\section{Type species: Pulvinata tomentosa}

Pulvinata tomentosa Ekanayaka \& K.D. Hyde, sp. nov.

Index Fungorum number: IF556276; Facesoffungi number: FoF 05868; Fig. 8.

Etymology - refers to tomentose margins

Holotype - MFLU 18-1819

Saprobic on dead stems. Sexual morph: Apothecia 700-800 $\times 300-350 \mu \mathrm{m}$, arising singly, sessile, slightly erumpent. Receptacle pulvinate. Margins raised, whitish to brownish, tomentose. Disc convex. Ectal excipulum 15-20 $\mu \mathrm{m}(\bar{x}=18.3 \mu \mathrm{m}, \mathrm{n}=10)$ in upper flanks, composed of, thinwalled, light brown to hyaline cells of textura angularis. Medullary excipulum $13-18 \mu \mathrm{m}(\bar{x}=15$ $\mu \mathrm{m}, \mathrm{n}=10$ ) in upper flanks, composed of, thin-walled, hyaline cells of textura intricata. Hymenium hyaline. Paraphyses $2-3 \mu \mathrm{m}$ wide $(\bar{x}=2.6 \mu \mathrm{m}, \mathrm{n}=20)$, numerous, filiform, obtuse and slightly swollen at the apex, aseptate, not exceeding the asci in length, smooth, aguttulate. Asci $65-80 \times 4-$ $5.5 \mu \mathrm{m}(\bar{x}=72 \times 4.9 \mu \mathrm{m}, \mathrm{n}=30) 8$-spored, unitunicate, cylindric-clavate, conical at the apex, amyloid ring present at the ascus apex, stipitate base, arising from croziers. Ascospores 8-12 $\times 2-3$ $\mu \mathrm{m}(\bar{x}=10.2 \times 2.5 \mu \mathrm{m}, \mathrm{n}=40), 1-2$-seriate, ellipsoid to fusoid, aseptate, hyaline, guttulate. Asexual morph: Undetermined.

Material examined - UK, Hampshire, Hedge End, on herbaceous stem, 3 March 2016, E.B.G. Jones, GJ239a (MFLU 18-1819).

GenBank accessions - LSU- MK591965, ITS- MK584938, SSU- MK585026, RPB2MK373054

Notes - Our collection from UK grouped with Obtectodiscus aquaticus (CBS 553.79) sister to Loramyces clade with strong statistical support of $98 \%$ (Fig. 7). The ITS data of our collection is similar to that of Loramyces macrosporus (CBS 235.53) (431/462-93\% with 6 gaps), Loramyces juncicola (CBS 293.52) (428/460-93\% with 6 gaps) and Obtectodiscus aquaticus (CBS 553.79) (535/586-91\% with 26 gaps). The LSU region shows similarity to that of Loramyces macrosporus (CBS 235.53) (847/857-99\% with 1 gap) and Loramyces juncicola (CBS 293.52) (848/862-98\% with 7 gaps). Considering genetic differences and based on the guidelines for introducing new taxa provided by Jeewon and Hyde (2016), we introduce the new genus Pulvinata here.

Our new genus is similar to the genera Obtectodiscus and Loramyces in having filiform paraphyses, long cylindrical asci and ellipsoid to fusoid ascospores, but differs in having pulvinate apothecia (Obtectodiscus and Loramyces produce cupulate apothecia), paraphyses with slightly swollen apices, amyloid asci and aseptate ascospores without appendages (Müller et al. 1979, Digby \& Goos 1987).

Our collection is similar to Tapesia in having whitish to brownish apothecia cylindric-clavate, amyloid asci and ellipsoid to fusoid ascospores, but differs in having pulvinate apothecia and long stipitate asci (Gminder 2006, 2012). 


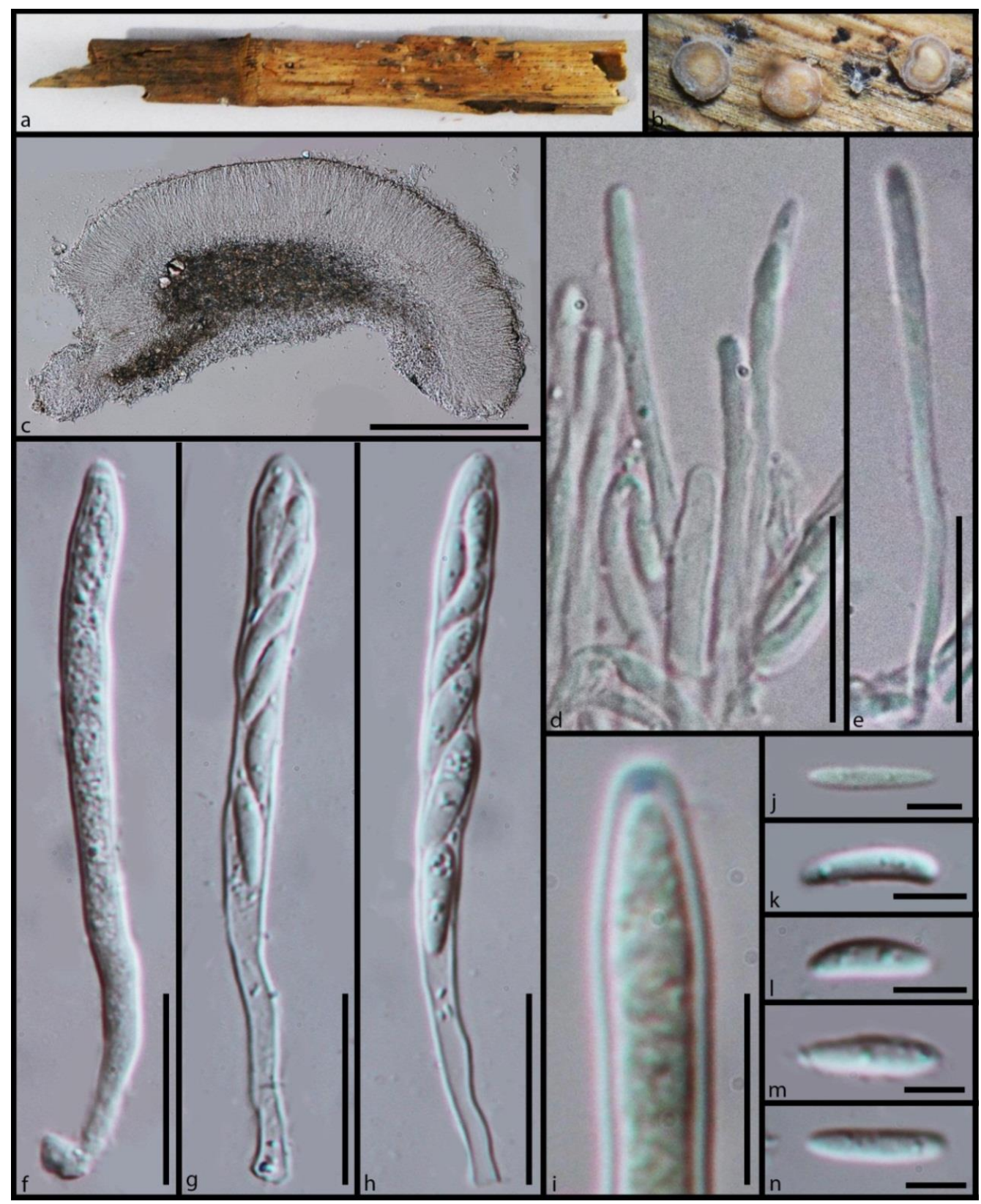

Figure 8 - Morphology of Pulvinata tomentosa (MFLU 18-1819 holotype) a Substrate. b Apothecia on wood. c Cross section of an apothecium. $d$, e Cylindrical paraphyses. $f-h$ Cylindricclavate asci. i Apex of the asci with the plug blueing in Melzer's reagent. j-n Fusoid ascospores. Scale bars: $\mathrm{c}=100 \mu \mathrm{m}, \mathrm{d}-\mathrm{h}=20 \mu \mathrm{m}, \mathrm{i}=10 \mu \mathrm{m}, \mathrm{j}-\mathrm{n}=5 \mu \mathrm{m}$.

Neopyrenopeziza Ekanayaka \& K.D. Hyde, gen. nov.

Index Fungorum number: IF556277; Facesoffungi number: FoF 05869

Etymology - refers to the similarity with the genus Pyrenopeziza.

Saprobic on dead stems. Sexual morph: Apothecia arising singly or in small groups, sessile, erumpent, pulvinate, black. Receptacle convex, disc and the margins are black. Ectal excipulum composed of highly pigmented cells of textural angularis to prismatica with vertically striate structures. Medullary excipulum composed of cells of textura prismatica. Hymenium hyaline. Paraphyses filiform, obtuse, enlarged and pigmented towards the apex, branched, septate. Asci 8spored, cylindric-clavate, conical at the apex, amyloid, short stipitate, arising from croziers. Ascospores hyaline, smooth walled, ellipsoid to fusoid, regularly 5-septate, distinctly more tapered towards the distal end. Asexual morph: Undetermined.

Type species: Neopyrenopeziza nigripigmentata 


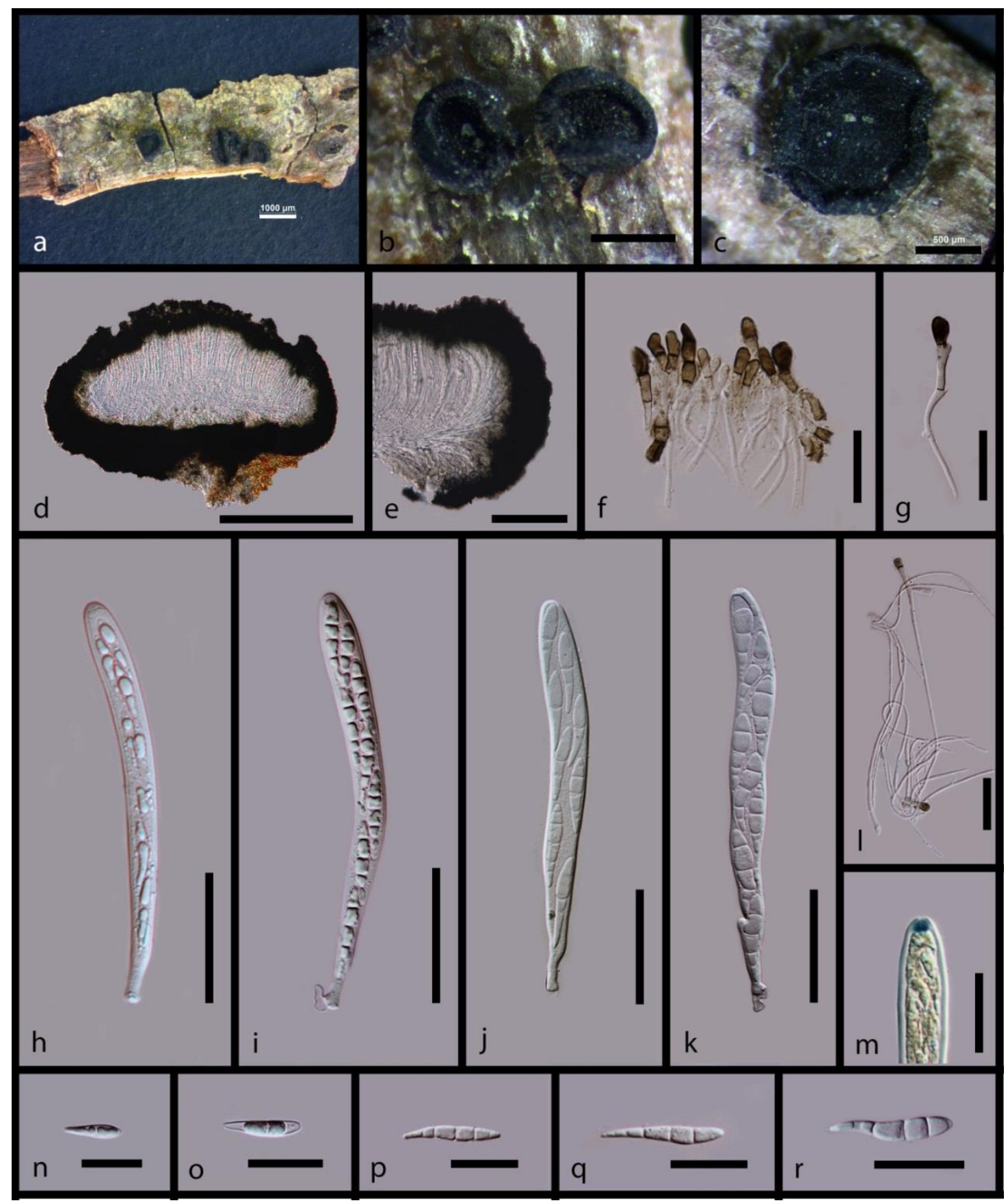

Figure 9 - Morphology of Neopyrenopeziza nigripigmentata (MFLU 16-0599 holotype) a Substrate. b Apothecia on wood. c Apothecium on bark. d Cross section of an apothecium. e Vertical section of the apothecium at margin. f Clavate hairs. g Clavate hair. h-k Cylindrical asci. 1 Septate and branched paraphyses. $m$ Amyloid ring at the ascus apex. $\mathrm{n}-\mathrm{r}$ Clavate ascospores. Scale bars: $\mathrm{a}=1000, \mathrm{~b}, \mathrm{c}=500 \mu \mathrm{m}, \mathrm{d}=400 \mu \mathrm{m}, \mathrm{e}=100 \mu \mathrm{m}, \mathrm{f}, \mathrm{g}=25 \mu \mathrm{m}, \mathrm{h}-\mathrm{k}=40 \mu \mathrm{m}, \mathrm{l}=30 \mu \mathrm{m}, \mathrm{m}=$ $50 \mu \mathrm{m}, \mathrm{n}-\mathrm{r}=25 \mu \mathrm{m}$.

Neopyrenopeziza nigripigmentata Ekanayaka \& K.D. Hyde, sp. nov.

Index Fungorum number: IF556278; Facesoffungi number: FoF 05870; Fig. 9.

Etymology - refers to the pigmented excipulum and paraphyses

Holotype - MFLU 16-0599

Saprobic on dead stems. Sexual morph: Apothecia 890-910 $\times 780-800 \mu \mathrm{m}(\bar{x}=900 \times 790$ $\mu \mathrm{m}, \mathrm{n}=10$ ) arising singly or in small groups, sessile, erumpent from the substrate, pulvinate, black when fresh. Receptacle convex, disc and the margins are black when fresh. Ectal excipulum 18-22 $\mu \mathrm{m}(\bar{x}=19 \mu \mathrm{m}, \mathrm{n}=10)$ thick, black to bark brown pigmented cells of textural angularis to 
prismatica, globose, granulate and pigmented apical cells form vertically striate structures. Medullary excipulum 24-33 $\mu \mathrm{m}(\bar{x}=26 \mu \mathrm{m}, \mathrm{n}=10)$ composed of narrow, long, thin-walled, hyaline cells of textura prismatica. Hymenium hyaline. Paraphyses $1-2 \mu \mathrm{m}$ wide $(\bar{x}=1.4 \mu \mathrm{m}, \mathrm{n}=$ 20), numerous, filiform, obtuse, enlarged and pigmented towards the apex, branched, septate. Asci 120-160 ×9-14 $\mu \mathrm{m}(\bar{x}=139 \times 13 \mu \mathrm{m}, \mathrm{n}=30) 8$-spored, cylindric-clavate, conical at the apex, amyloid, short stipitate, arising from croziers. Ascospores $24.5-42 \times 5-6 \mu \mathrm{m}(\bar{x}=36 \times 6 \mu \mathrm{m}, \mathrm{n}=$ 40), partially biseriate, lower spores are uniseriate, hyaline, smooth walled, ellipsoid to fusoid, regularly five septate, distinctly more tapered towards the distal end. Asexual morph: Undetermined.

Material examined - Italy, Arezzo Province, Papiano - Stia, on dead aerial branches of Crataegus sp., 14 May 2014, Erio Camporesi, IT1871 (MFLU 16-0599).

GenBank accessions - LSU- MK592001, ITS- MK584981, SSU- MK585057

Notes - According to our phylogeny study, our strain IT1871 from Italy clustered with Patellariopsis dennisii (G.M-2017-09-04-3) sister to Mollisia ligni clade with strong statistical support of $100 \%$ (Fig. 7).

The ITS data of our collection is similar to that of Patellariopsis dennisii (G.M.2017-09-04.3) (539/546-99\% with 0 gaps) and Mollisia ligni (BHI-F738a) (502/558-90\% with 14 gaps). The LSU region is similar to that of Loramyces macrosporus (CBS 235.53) (807/824-98\% with 2 gaps) and to Patellariopsis atrovinosa (G.M. 2016-05-04.1) (784/831-94\% with 9 gaps). According to the guidelines for introducing new taxa provided by Jeewon \& Hyde (2016), herein we introduce the new genus Neopyrenopeziza here.

The genus Neopyrenopeziza is similar to the genera Pyrenopeziza and Mollisia in having blackish, pulvinate apothecia with vertically striate structures on the excipular surface, cylindricclavate, amyloid asci and ellipsoid to fusoid ascospores (Rawlinson et al. 1978, Hütter 1958, Gremmen 1958, Schüepp 1959, Crous et al. 2017, Gminder 2012). However, Neopyrenopeziza differs in having paraphyses with pigmented apices and clavate ascospores with tapered ends. Moreover, Neopyrenopeziza differs from Patellariopsis in having pulvinate receptacle and pigmented excipulum (Dennis 1974, Beaton \& Weste 1978).

Our phylogeny shows that, the genera Patellariopsis and Mollisia are polyphyletic.

Furthermore, Patellariopsis dennisii (G.M.2017-09-04.3) clustered with our new strain while Patellariopsis dennisii (CBS 174 66) clustered with taxa of Mollisiaceae. Therefore, we suggest the genera Patellariopsis and Mollisia require further phylogenetic analyses to establish their generic limitations.

Neomollisia Ekanayaka \& K.D. Hyde, gen. nov.

Index Fungorum number: IF556279; Facesoffungi number: FoF 05871

Etymology - refers to the similarity with the genus Mollisia.

Saprobic on dead stems. Sexual morph: Apothecia arising singly, sessile, slightly erumpent, rounded to irregular in shape. Receptacle pulvinate. Disc convex. Ectal excipulum composed of blackish cells of textura angularis. Medullary excipulum composed of hyaline cells of textura prismatica. Hymenium hyaline and embedded in a thick gel. Paraphyses numerous, filiform, obtuse and slightly swollen at the apex, septate, sometimes exceeding the asci in length, smooth, aguttulate. Asci arising from croziers, 8-spored, unitunicate, cylindric-clavate, conical and amyloid apex, stipitate base. Ascospores 1-2-seriate, fusoid, aseptate, hyaline, guttulate. Asexual morph: Undetermined.

Type species: Neomollisia gelatinosa

Neomollisia gelatinosa Ekanayaka \& K.D. Hyde, sp. nov.

Index Fungorum number: IF556280; Facesoffungi number: FoF 05872; Fig. 10.

Etymology - refers to the gelatinized hymenium

Holotype - MFLU 18-0701 
Saprobic on dead stems. Sexual morph: Apothecia $0.5-1 \mathrm{~mm}$ diam., arising singly, sessile, slightly erumpent, rounded to irregular in shape. Receptacle pulvinate. Margins ash, raised and inrolled. Disc convex. Ectal excipulum 30-35 $\mu \mathrm{m}(\bar{x}=32.8 \mu \mathrm{m}, \mathrm{n}=10)$ in lower flanks, composed of, thin-walled, blackish cells of textura angularis, apical cells form vertically striate structures. Medullary excipulum 18-28 $\mu \mathrm{m}(\bar{x}=24 \mu \mathrm{m}, \mathrm{n}=10)$ in lower flanks, composed of, thin-walled, hyaline cells of textura prismatica. Hymenium hyaline, gelatinized. Paraphyses $2-3.5 \mu \mathrm{m}$ wide $(\bar{x}$ $=3.1 \mu \mathrm{m}, \mathrm{n}=20$ ), numerous, filiform, obtuse and slightly swollen at the apex, gelatinized, septate, sometimes exceeding the asci in length, smooth, aguttulate. Asci 38-43 $\times 4-4.5 \mu \mathrm{m}(\bar{x}=41.4 \times 4.1$ $\mu \mathrm{m}, \mathrm{n}=30), 8$-spored, unitunicate, cylindric-clavate, conical and amyloid apex, stipitate base, arising from croziers. Ascospores 8-11 $\times 2-2.5 \mu \mathrm{m}(\bar{x}=9.2 \times 2.2 \mu \mathrm{m}, \mathrm{n}=40), 1$-2-seriate, fusoid, aseptate, hyaline, guttulate. Asexual morph: Undetermined.

Material examined - Russia, Rostov region, Shakhty City District, former sand quarry "Belyy Fyodor", meadow, saprobic on dead stems of Solidago gigantea Aiton (Asteraceae), 11 June 2017, Timur S. Bulgakov, T-1700 (MFLU 18-0701).

GenBank accessions - LSU- MK591960, ITS- MK585004, SSU- MK585021, TEFMK637043, RPB2- MK358463

Notes - According to our study, strain MFLU 18-0701 from Russia formed a separate clade within Loramycetaceae sister to the Acidomelania clade with strong statistical support of 96\% (Fig. 7).

The LSU region of our collection shows similarity to that of Hymenoscyphus vitellinus (CBS 139.24) (869/878-99\% with 2 gaps), Acidomelania panicicola (CBS 137156) (750/758-99\% with 1 gap) and Mollisia cinerea (CBS 128349) (869/879(99\% with 2 gaps). The ITS data of our collection is similar to that of Mollisia cinerea (BHI-F197a) (741/796-93\% with 11 gaps) and Mollisia melaleuca (CBS 589.84) (635/662-96\% with 3 gaps). Therefore, according to the guidelines for introducing new taxa provided by Jeewon \& Hyde (2016), here we introduce the new genus Neomollisia here.

The genus Neomollisia is similar to the genera Neopyrenopeziza, Pyrenopeziza and Mollisia by having blackish, pulvinate apothecia with vertically striate structures on the excipular surface, cylindric-clavate, amyloid asci and ellipsoid to fusoid ascospores (Rawlinson et al. 1978, Hütter 1958, Gremmen 1958, Schüepp 1959, Crous et al. 2017, Gminder 2012). However, Neomollisia differs in having raised and enrolled margins and a gelatinized hymenium.

\section{Heterosphaeriaceae Rehm}

Facesoffungi number: FoF 05873

Taxa are saprobic on dead plant material. Ascomata are apothecial. Apothecia are discoid, black, sessile, erumpent and gelatinous. The ectal excipulum is composed of cells of textura angularis and medullary excipulum is composed of cells of textura porrecta. Paraphyses are filiform, clavate and contain many guttules. Asci are 8-spored, amyloid and arising from croziers. Ascospores are aseptate, ellipsoid to fusoid and without gel sheath (Leuchtmann 1987). Asexual morphs are synanamorphic, hyphomycetous acervulus and ceolomycetous. Conidiomata are discoid. Conidia are ellipsoid to fusoid with pointed ends, hyaline and aseptate (Leuchtmann 1987).

Notes - According to our phylogenetic analysis this family formed a well-supported clade close to Drepanopezizaceae and Hydrocinaceae (Fig. 1). Heterosphaeriaceae taxa are similar to Drepanopezizaceae from their ascospores and conidia morphologies (Jaklitsch et al. 2016).

\section{Heterosphaeria linariae (Rabenh.) Rehm}

Facesoffungi number: FoF 05874; Fig. 12

Saprobic on dead stems. Sexual morph: Apothecia $0.5-1 \times 0.3-0.6 \mathrm{~mm}$, arising singly, sessile, slightly erumpent, subsphaerical, black. Receptacle cupulate. Margins cover the hymenium at the beginning and split into lobes at maturity. Disc concave. Ectal excipulum 17-22 $\mu \mathrm{m}(\bar{x}=20.3 \mu \mathrm{m}$, $\mathrm{n}=10$ ) in lower flanks, composed of, thin-walled, black cells of textura angularis. 


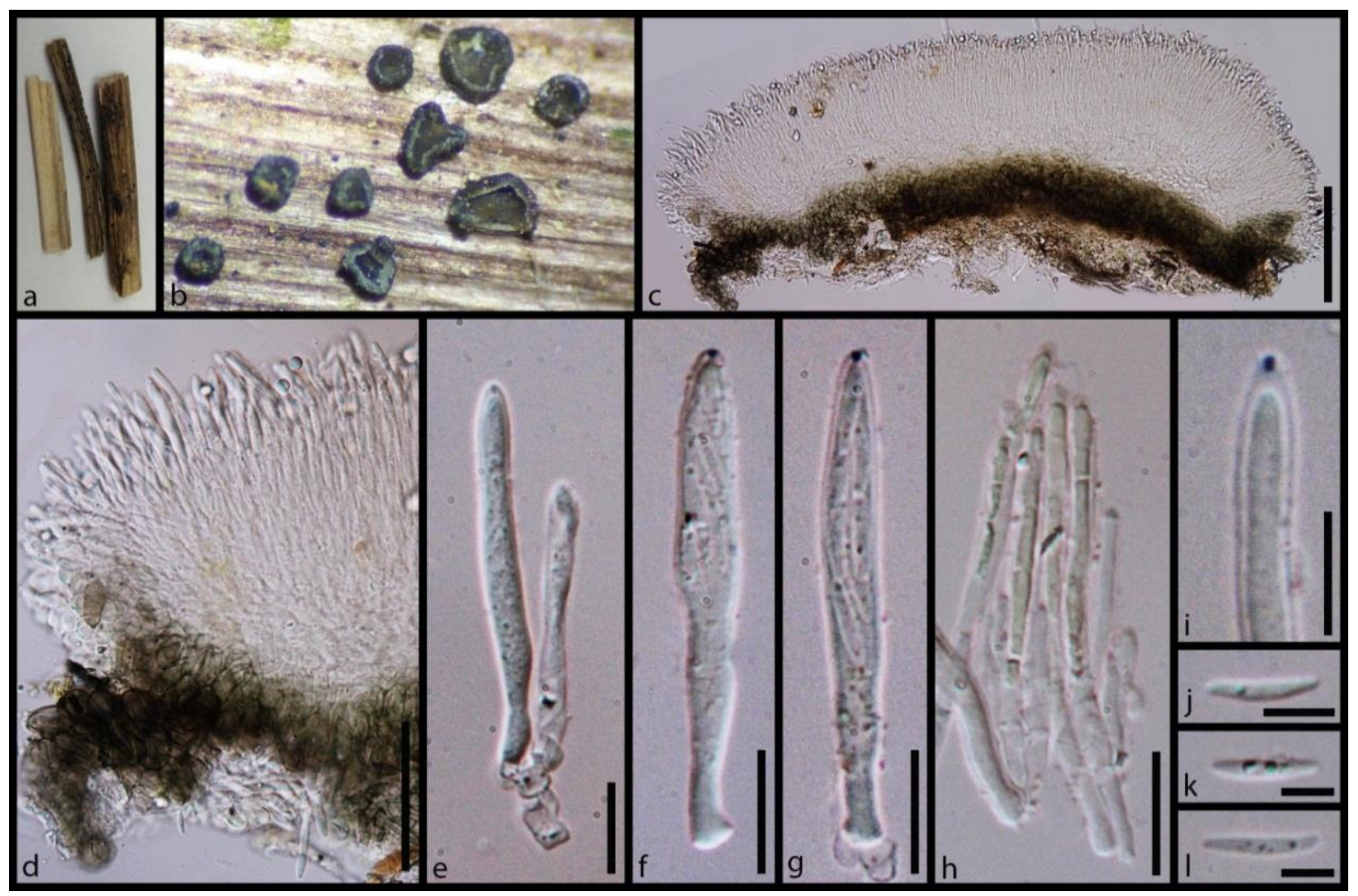

Figure 10 - Morphology of Neomollisia gelatinosa (MFLU 18-0701 holotype) a Substrate. b Apothecia on wood. c Cross section of an apothecium. d Close up of the cross section of apothecium at margins. e-g Cylindric-clavate asci. h Septate paraphyses. i Amyloid ascus apex (in Melzer's reagent). j-l Fusoid ascospores. Scale bars: $\mathrm{c}=100 \mu \mathrm{m}, \mathrm{d}=50 \mu \mathrm{m}, \mathrm{e}-\mathrm{g}=10 \mu \mathrm{m}, \mathrm{h}=15$ $\mu \mathrm{m}, \mathrm{i}=5 \mu \mathrm{m}, \mathrm{j}-1=5 \mu \mathrm{m}$.

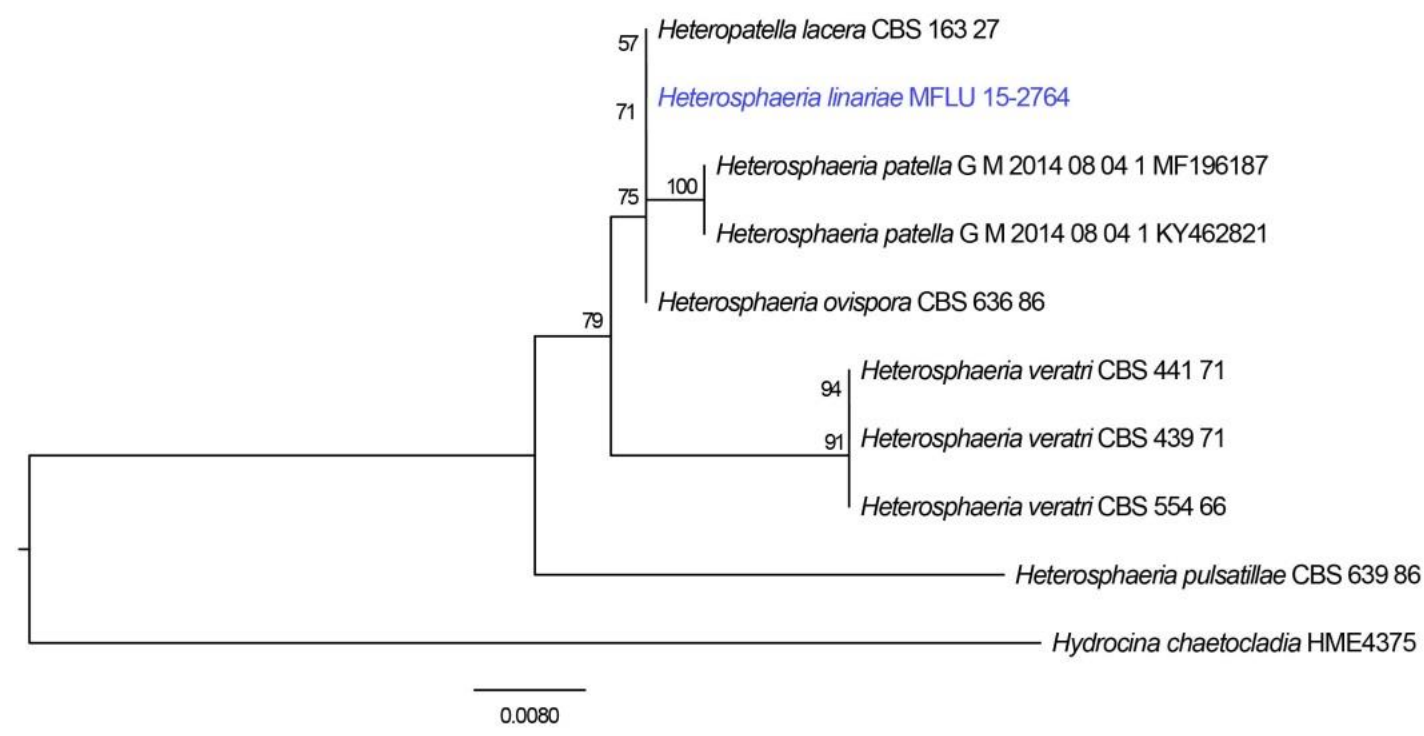

Figure 11 - Phylogram generated from maximum likelihood analysis of sequences of Heterosphaeria based on ITS and LSU sequence data. MLBP values $\geq 50 \%$ are given near the nodes. Strain/culture numbers are given after the taxon names. The tree is rooted with Hydrocina chaetocladia (HME4375). 
Medullary excipulum 40-47 $\mu \mathrm{m}(\bar{x}=43 \mu \mathrm{m}, \mathrm{n}=10)$ in lower flanks, composed of, thin-walled, hyaline cells of textura porrecta. Hymenium hyaline. Paraphyses $1.8-2 \mu \mathrm{m}$ wide $(\bar{x}=1.9 \mu \mathrm{m}, \mathrm{n}=$ $20)$, numerous, filiform, obtuse and slightly enlarged at the apex, aseptate, exceeding the asci in length, smooth, guttulate. Asci 35-50 $\times 4.5-6 \mu \mathrm{m}(\bar{x}=43 \times 5 \mu \mathrm{m}, \mathrm{n}=30)$ arising from croziers, unitunicate, cylindric, apex conical, stipitate base, arising from croziers. Ascospores not observed. Asexual morph: Undetermined.

Material examined - Russia, Arkhangelsk region, Akhangelsk City, Maimaksansky City District, floodplain meadow, saprobic on dead stem of Linaria vulgaris Mill. (Plantaginaceae), 3 May 2015, Gennady V. Okatov, T-597 (MFLU 15-2764).

GenBank accessions - LSU- MK591955, ITS- MK585000, SSU-MK585014, TEFMK637042, RPB2- MK343131

Notes - Our collection from Russia grouped with Heteropatella lacera (CBS 163 27) (Fig. 11). The ITS and LSU data of our collection shows $100 \%$ similarity to that of Heteropatella lacera (CBS 163.27) (ITS: 532/532-100\%, LSU: 689/689-100\%).

Heteropatella is a ceolomycetous genus which is the sexual morph of Heterosphaeria. Heterosphaeria linariae is the sexual morph of Heteropatella lacera (Grove 1937).

There is a single strain available for Heterosphaeria ovispora (CBS 636.86) in GenBank and only LSU region available for this strain. This Heterosphaeria ovispora (CBS 636.86) strain is $100 \%$ similar to that of our strain and to Heteropatella lacera (CBS 163.27). Considering the descriptions of Heterosphaeria linariae (Rehm 1888) and Heterosphaeria ovispora (Leuchtmann 1987), we suggest that both of these species are the same. Morphology of our collection is similar to the descriptions of Heterosphaeria linariae (Rehm 1888) and Heterosphaeria ovispora (Leuchtmann 1987), except having smaller asci. However, in our collection we did not observe ascospores and the ascomata are always closed. Therefore, the asci may still be immature.

\section{Mitrulaceae Rchb.}

Facesoffungi number: FoF 05875

Saprobic on dead plant material in shallow water habitats (Redhead 1977). Ascomata are apothecial. Apothecia are clavate and stipitate. The hymenium is white to flesh-pinkish or yelloworange. The ectal excipulum is composed of cells of textura porrecta and medullary excipulum is composed of cells of textura intricata. Paraphyses are filiform, cylindrical and with yellow carotenoid droplets. Asci are 8-spored, cylindric-clavate and arising from croziers. Ascospores are fusoid to ellipsoid and straight or curved (Redhead 1977, Wang et al. 2005). Asexual morphs are not recorded.

Notes - This genus was formerly placed in Geoglossaceae based on its clavate apothecia (Redhead 1977). According to phylogenetic relationships it is currently placed within Leotiomycetes (Wang et al. 2005).

\section{Gelatinodiscaceae S.E. Carp.}

Facesoffungi number: FoF 05876

Taxa are saprobic, endophytic or endophytic (Shoji 1985, Seaver 1938, Johnston \& Park 2010). Ascomata are apothecial. Apothecia are mostly cupulate or discoid; some are tremelloid and form cerebriform masses which each lobule contains a turbinate apothecium. The ectal excipulum is composed of cells of textura prismatica to textura angularis to globulosa and sometimes gelatinized and medullary excipulum is composed of cells of textura oblita to textura porrecta or textura intricata and sometimes gelatinized. Paraphyses are filiform, cylindrical, apically swollen and guttulate. Asci are 8-spored, amyloid and arising from croziers. Ascospores are ellipsoid to fusoid, hyaline, yellowish or brownish, smooth, with a gelatinous sheath, guttulate and 0-5-septate (Seaver 1938, Johnston \& Park 2010, Huhtinen 1987b, Beaton \& Weste 1976, Baral et al. 2012, Johnston \& Park 2010). Asexual morphs are sporodochial. Conidia are aseptate, hyaline and subglobose (Seaver 1938, Johnston \& Park 2010). 
Notes - This family produce small gelatinized apothecia. In our study this family formed a monophyletic clade close to Mitrulaceae. The genera Helicodendron and Dimorphospora were previously classified under Helotiaceae (Wijayawardene et al. 2018). Sri-indrasutdhi et al. (2015) showed these genera are genetically related to Gelatinodiscaceae. Therefore, here we included Helicodendron under Gelatinodiscaceae.

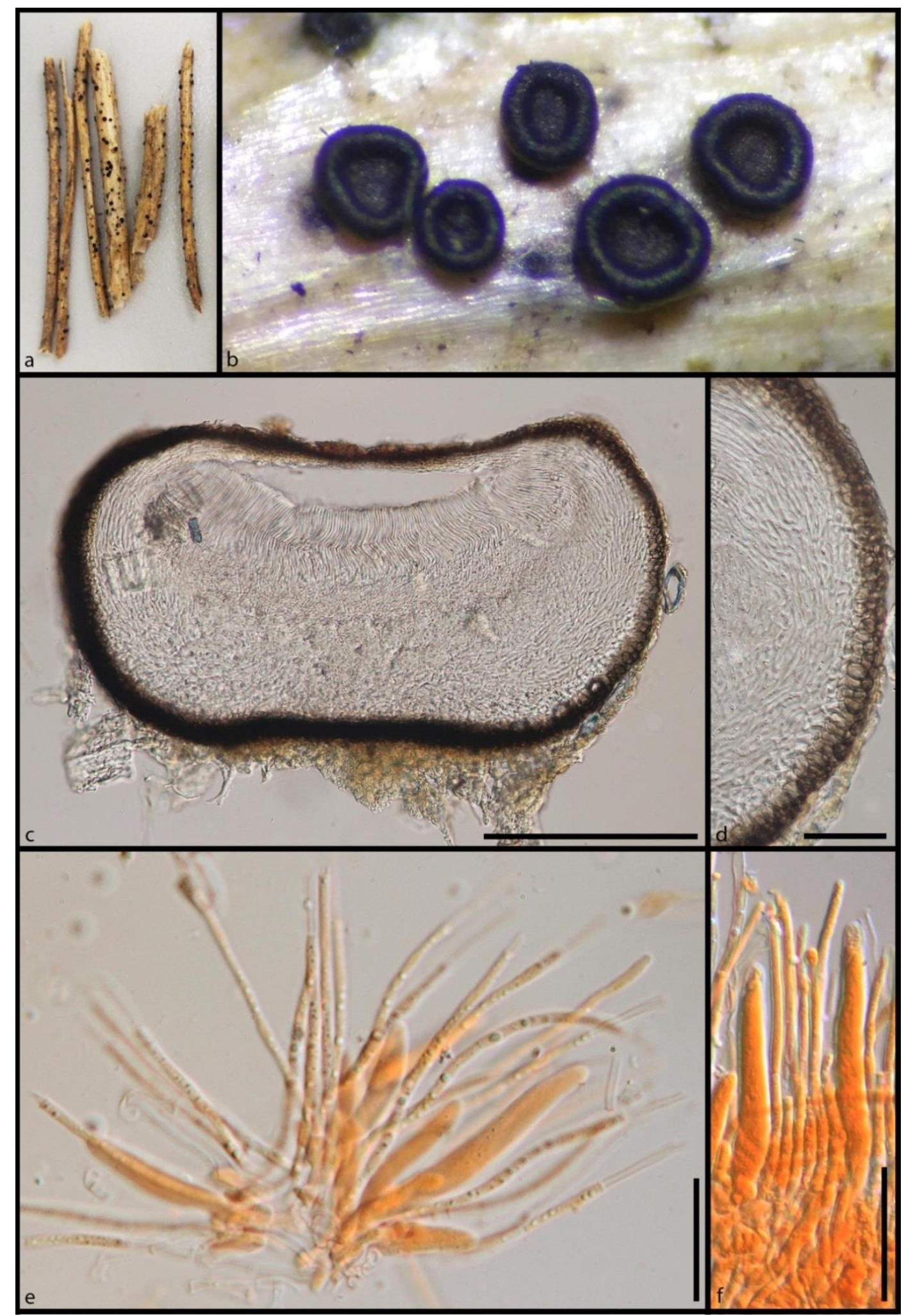

Figure 12 - Morphology of Heterosphaeria linariae (MFLU 15-2764) a Substrate. b Apothecia on wood. c Cross section of an apothecium. d Close up of the cross section of apothecium at flanks. e, f Asci and paraphyses in Congo red. Scale bars: $\mathrm{c}=500 \mu \mathrm{m}, \mathrm{d}=50 \mu \mathrm{m}, \mathrm{e}-\mathrm{f}=20 \mu \mathrm{m}$. 


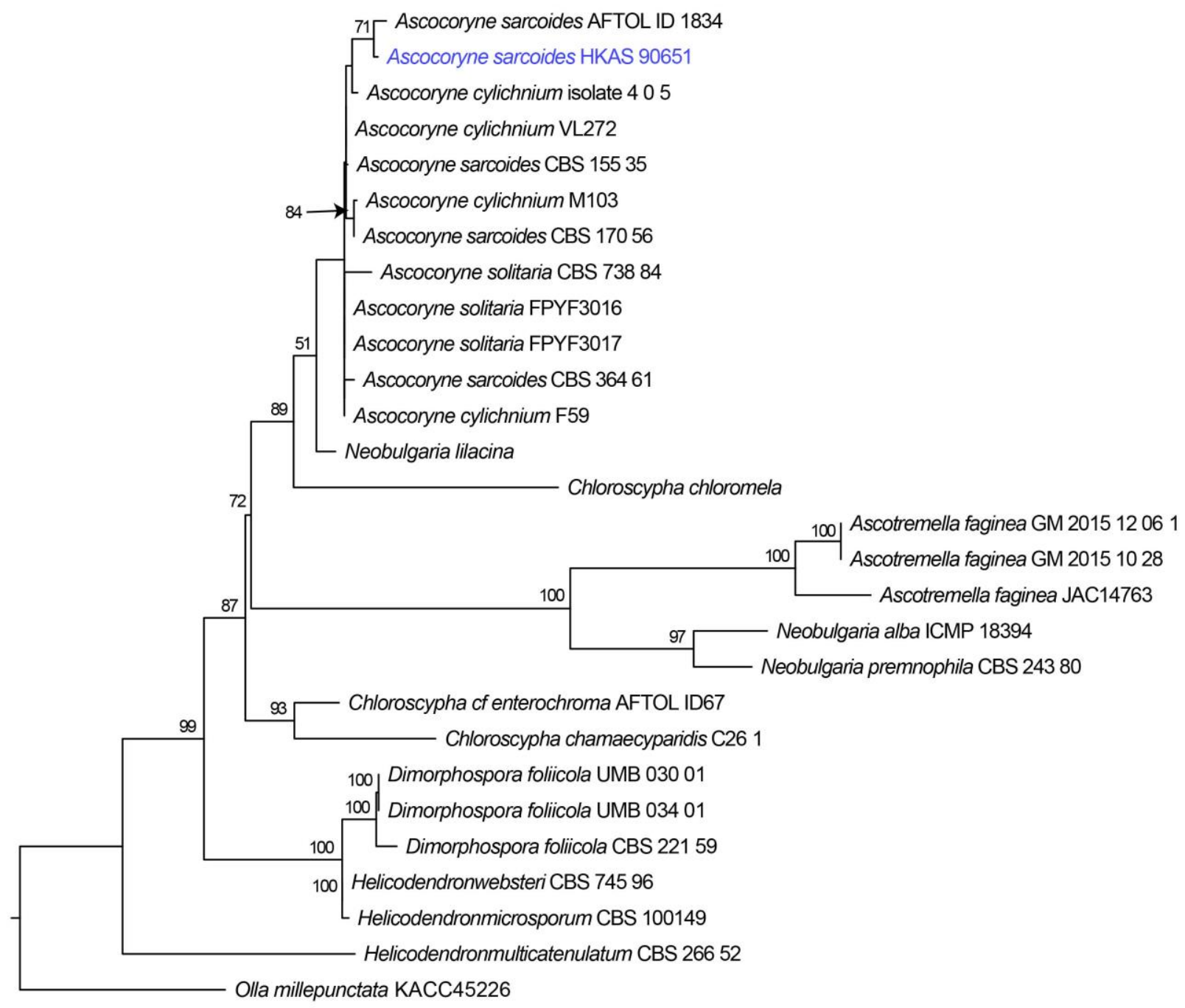

0.04

Figure 13 - Phylogram generated from maximum likelihood analysis of sequences of Gelatinodiscaceae based on ITS and LSU sequence data. MLBP values $\geq 50 \%$ are given near the nodes. Strain/culture numbers are given after the taxon names. The tree is rooted with Olla millepunctata (KACC45226).

Ascocoryne sarcoides (Jacq.) J.W. Groves \& D.E. Wilson

Facesoffungi number: FoF 05877; Fig. 14

Saprobic on dead stems. Sexual morph: Apothecia $2-3 \times 1-1.5 \mathrm{~mm}$, arising in clusters, sessile. Receptacle discoid, purple to black. Disc concave, black. Ectal excipulum 16-22 $\mu \mathrm{m}(\bar{x}=$ $20.3 \mu \mathrm{m}, \mathrm{n}=10$ ) in lower flanks, composed of, thin-walled, light brown to hyaline cells of textura angularis. Medullary excipulum $80-100 \mu \mathrm{m}(\bar{x}=90 \mu \mathrm{m}, \mathrm{n}=10)$ in lower flanks, composed of, thin-walled, hyaline cells of textura intricata. Hymenium hyaline. Paraphyses $2-3.2 \mu \mathrm{m}(\bar{x}=2.5$ $\mu \mathrm{m}, \mathrm{n}=20$ ) wide at tips, numerous, filiform, obtuse and swollen at the apex, aseptate, exceeding the asci in length, smooth, aguttulate. Asci 135-160 $\times 8-9 \mu \mathrm{m}(\bar{x}=149.2 \times 8.7 \mu \mathrm{m}, \mathrm{n}=30)$ arising from croziers, 8-spored, unitunicate, cylindrical, apex rounded and amyloid, stipitate base, arising from croziers. Ascospores $15-25 \times 4.5-6 \mu \mathrm{m}(\bar{x}=21 \times 5.6 \mu \mathrm{m}, \mathrm{n}=40), 1-2$-seriate, fusoid, $1-$ septate, hyaline. Asexual morph: Undetermined.

Material examined - China, Yunnan Province, Shangri-La, Da-cuo National Park, opposite of Bi-Ta Lake, alt. 3556m, 22 September 2015, Bo Li, HK04 (HKAS 90651).

GenBank accessions - LSU- MK591999, ITS- MK584973, SSU- MK585054, TEFMK637051, RPB2- MK614731 
Notes - Our collection of Ascocoryne sarcoides from China grouped with Ascocoryne sarcoides (AFTOL ID 1834) with strong statistical support (71\%) (Fig. 13). The ITS data of our collection shows $99 \%$ similarity to Ascocoryne sarcoides (CBS 155.35, CBS 170.56), Ascocoryne cylichnium (strain VL272) and Ascocoryne solitaria (CBS:738.84). The LSU region of our species is $99 \%$ similar to Ascocoryne sarcoides (CBS 364.61, CBS 407.69).

Our collection is similar to Ascocoryne sarcoides (Kuo 2013), however in our collection asci are slightly longer.

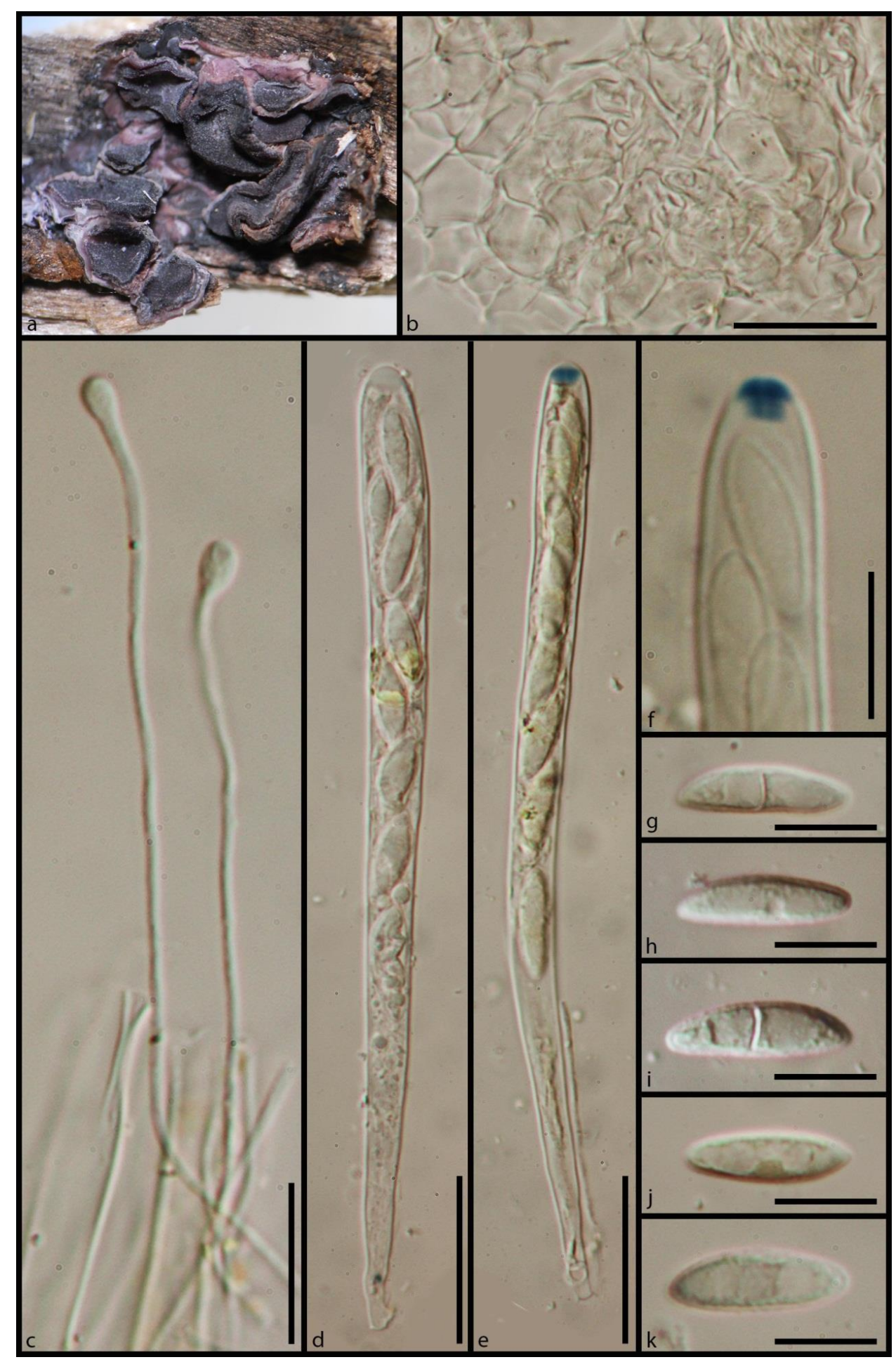

Figure 14 - Morphology of Ascocoryne sarcoides (HKAS 90651) a Apothecia on wood. b Ectal excipular cells. c Apically swollen paraphyses. d-e Cylindrical asci. f Amyloid apex. g-k Fusoid ascospores. Scale bars: $\mathrm{b}, \mathrm{c}=20 \mu \mathrm{m}, \mathrm{d}, \mathrm{e}=25 \mu \mathrm{m}, \mathrm{f}-\mathrm{k}=10 \mu \mathrm{m}$. 


\section{Mollisiaceae Rehm}

Facesoffungi number: FoF 05878

Taxa are saprobic or plant pathogenic. Some form mycorrhizal associations. Ascomata are apothecial and characterized by discoid receptacle covered with hairs. The ectal excipulum is composed of cells of textura globulosa to angularis and medullary excipulum is composed of cells of textura prismatica. Paraphyses are filiform, cylindrical or lanceolate, apically swollen and guttulate. Asci are 8-spored, amyloid, cylindric clavate and mostly arising from croziers. Ascospores are 0-7-septate, ellipsoid to long-filiform and guttulate (Müller \& Hütter 1963, Crous et al. 2007, Nannfeldt 1983, Graddon 1990, 1984, Gminder 2012, Prasher et al. 2003, Dennis 1962, Dennis and Spooner 1993). Asexual morphs are sporodochial. Conidiophores are hyaline to brown. Conidia are unicellular, ellipsoid or phragmosporous, hyaline or brown and also in chains (Sutton \& Ganapathi 1978, Butin et al. 1996, Grünig et al. 2002).

Notes - This forms a sister clade with Loramycetaceae. Even the most of taxa of the family form a monophyletic clade, the genera classified within the family, especially Mollisia and Trimmatostroma are highly polyphyletic and need more phylogenetic analyses to resolve them.

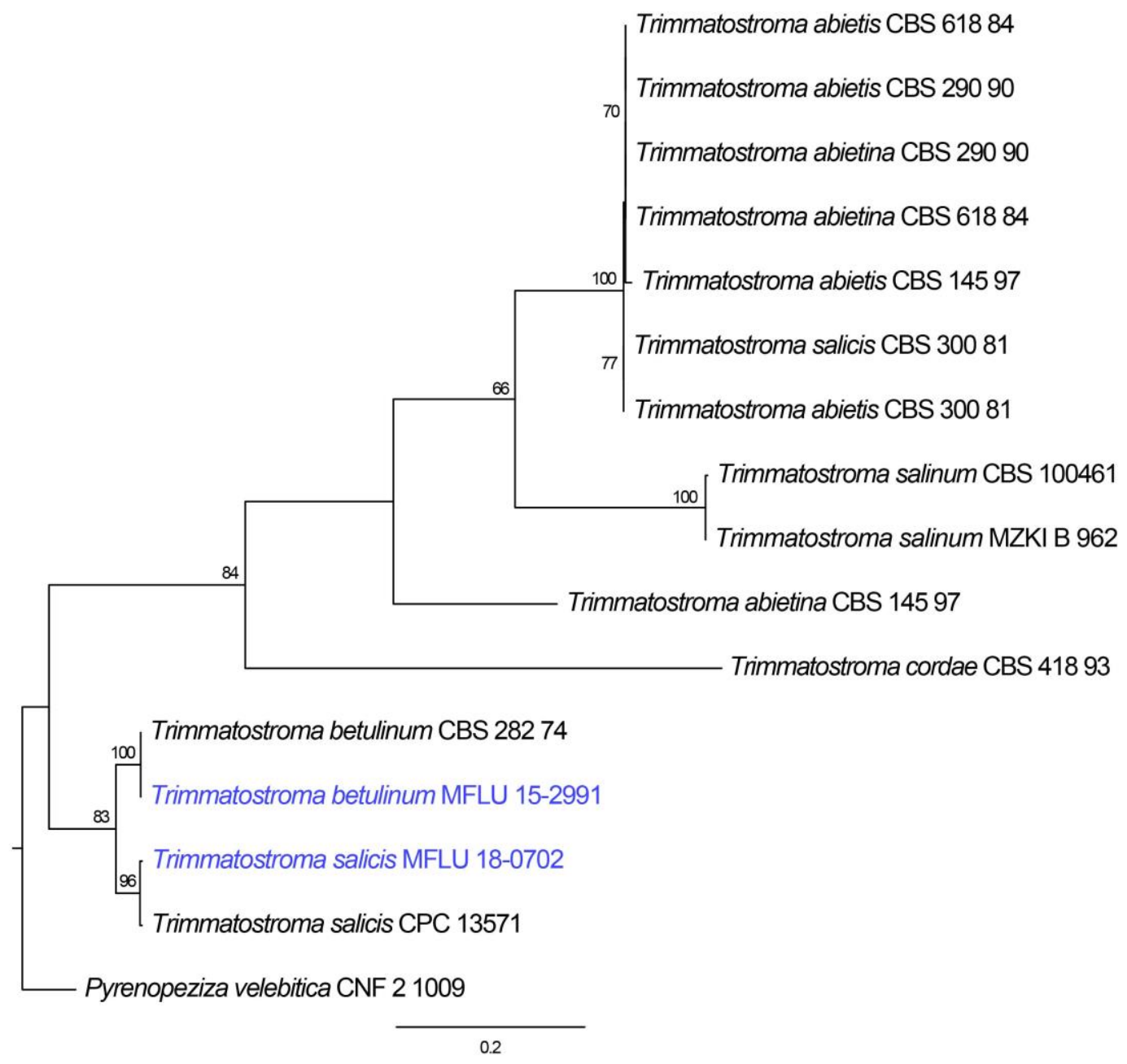

Figure 15 - Phylogram generated from maximum likelihood analysis of sequences of Trimmatostroma based on ITS sequence data. MLBP values $\geq 50 \%$ are given near the nodes. Strain/culture numbers are given after the taxon names. The tree is rooted with Pyrenopeziza velebitica (CNF 2 1009).

Trimmatostroma betulinum (Corda) S. Hughes

Facesoffungi number: FoF 05879; Fig. 16 
Saprobic on dead twigs and branches. Sexual morph: Undetermined. Asexual morph: Conidiomata $0.5-1.5 \mathrm{~mm}$ wide, single or in groups, dark brown to black, immersed, acervularsporodochial. Conidiogenous cells short, cylindrical, hyaline to light brown, micronematous, giving rise to long chains of conidia that disarticulate at the surface to form a grey black to brown powdery mass. Conidia 10-15 $\times 5-10 \mu \mathrm{m}(\mathrm{x}=12.4 \times 8.3 \mu \mathrm{m}, \mathrm{n}=20)$, ellipsoid ovoid to globose or subglobose, sometimes forming irregular aggregations composed of 2-6 cells, light brown to dark brown.

Material examined - Russia, Rostov region, Krasnosulinsky District, Gornensky Zakaznik (protected landscape), saprobic on dead twigs and branches of Betula pendula Roth (Betulaceae), 28 June 2015, Timur S. Bulgakov, T-848 (MFLU 15-2991).

GenBank accessions - LSU- MK591956, ITS- MK584993, SSU- MK585016

Notes - Our collection from Russia grouped with Trimmatostroma betulinum (CBS 282 74) with strong statistical support (100\%) (Fig. 15). The ITS data of our collection is $100 \%$ similar to that of Trimmatostroma betulinum (CBS 282.74) (745/745-100\%). The LSU region of our strain is 99\% similar to that of Trimmatostroma betulinum (CBS 282.74) (411/415-99\% with no gaps). The characters of our collection are similar to Trimmatostroma betulinum (Hughes 1953). Trimmatostroma salicis is similar to T. betulinum. However, T. salicis differs in having more branched conidia than T. betulinum (Hughes 1953).

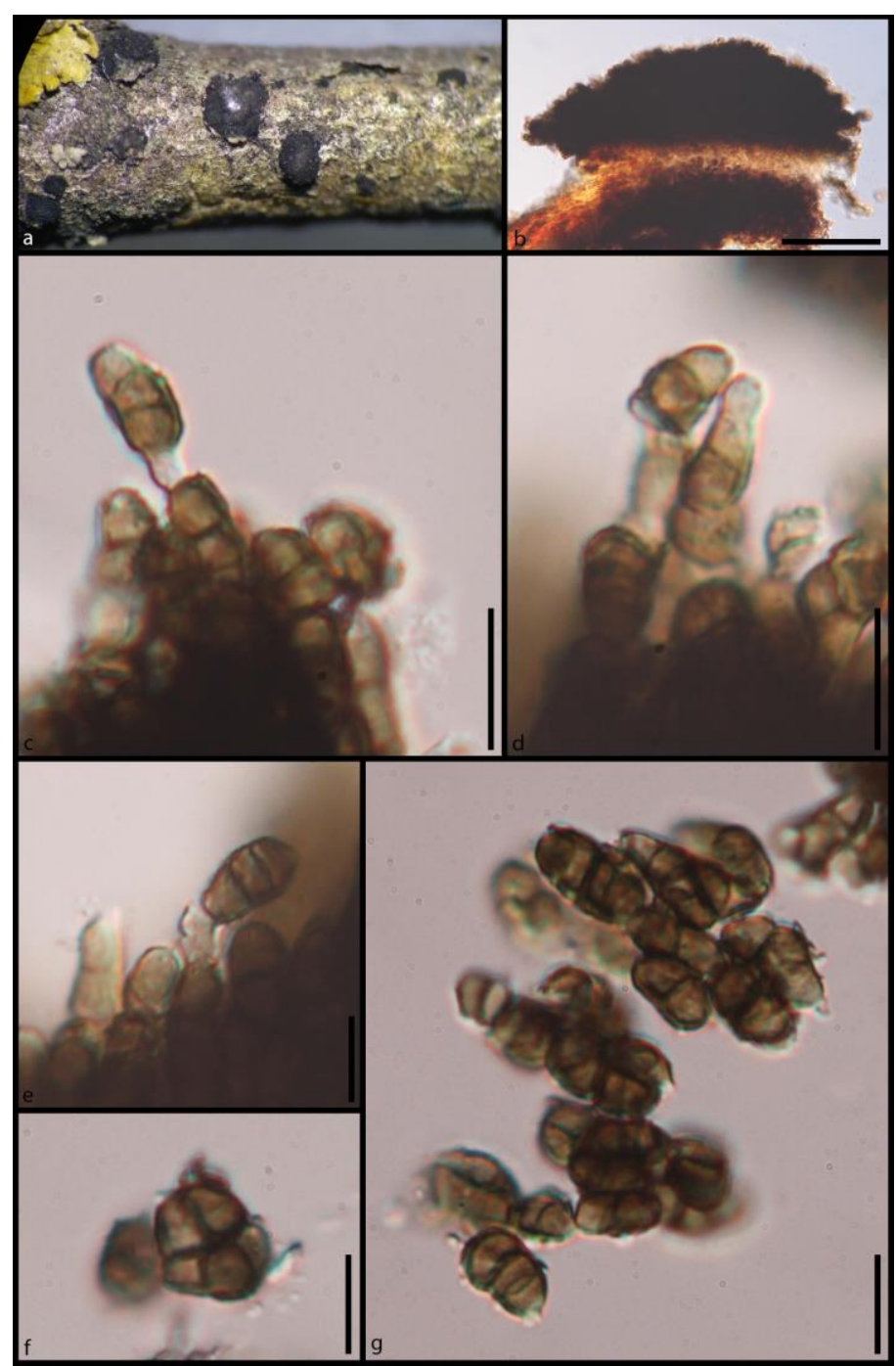

Figure 16 - Morphology of Trimmatostroma betulinum (MFLU 15-2991) a Conidiomata on substrate. $\mathrm{b}$ Cross section of conidioma. c-e Different stages of conidiogenesis. $\mathrm{f}$, g Conidia at different stages. Scale bars: $b=100 \mu \mathrm{m}, \mathrm{c}, \mathrm{d}=25$, e-g $=10 \mu \mathrm{m}$. 


\section{Trimmatostroma salicis Corda}

Facesoffungi number: FoF 05880; Fig. 17

Saprobic on dead twigs and branches. Sexual morph: Undetermined. Asexual morph: Conidiomata 1-2 mm wide, single or in groups, dark brown to black, semi-immersed, acervularsporodochial. Conidiogenous cells short, cylindrical, hyaline to light brown, micronematous, giving rise to long chains of conidia that disarticulate at the surface to form a grey black to brown powdery mass. Conidia 10-15 $\times 5-10 \mu \mathrm{m}(\mathrm{x}=13.2 \times 7.6 \mu \mathrm{m}, \mathrm{n}=20)$, ellipsoid to fusoid or subglobose, pale brown to dark brown, arise in basipetal chains, simple to branched.

Material examined - Russia, Rostov region, Krasnosulinsky District, Gornensky Zakaznik (protected landscape), trees on the riverside of Kundryuchya River, saprobic or weak parasitic on dying twigs of Salix alba L. (Salicaceae), 21 May 2014, Timur S. Bulgakov, T75 (MFLU 180702).

GenBank accessions - ITS- MK584996

Notes - Our collection T75 from Russia grouped with Trimmatostroma salicis (CPC 13571) with strong statistical support (100\%) (Fig. 15). The ITS data of our collection is $99 \%$ similar to Trimmatostroma salicis (CPC 13571) (649/656-99\% with 3 gaps) and 95\% to Trimmatostroma betulinum (CBS 282.74) (480/506-95\% with 4 gaps). The morphology of our collection is in agreement with the description of T. salicis from Hughes (1953).

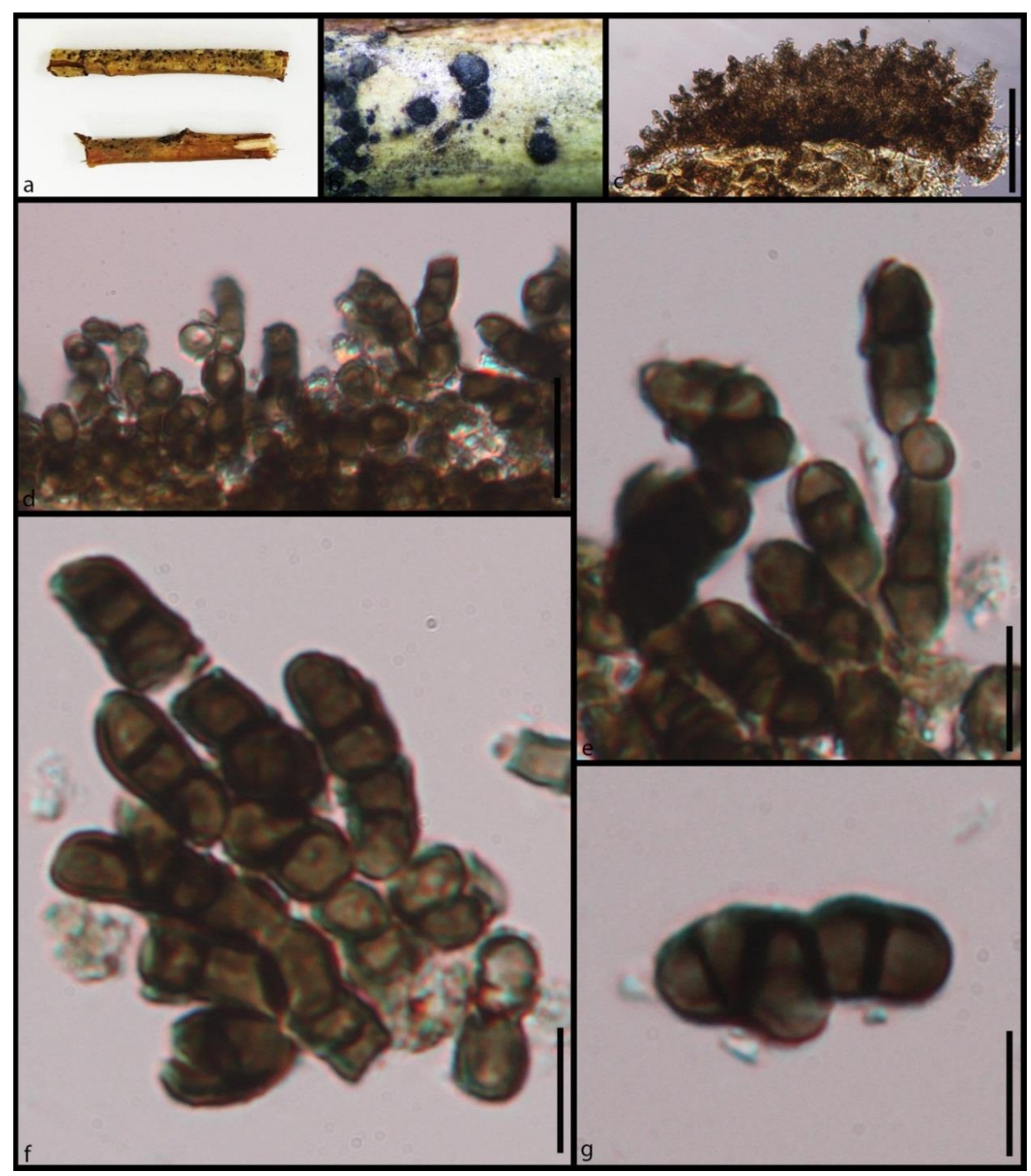

Figure 17 - Morphology of Trimmatostroma salicis (MFLU 18-0702) a Substrate. b Conidiomata on substrate. c Cross section of conidioma. d, e Different stages of conidiogenesis. $\mathrm{f}$, g Conidia at different stages. Scale bars: $c=100 \mu \mathrm{m}, \mathrm{d}=20, \mathrm{e}-\mathrm{g}=10 \mu \mathrm{m}$. 


\section{Ploettnerulaceae Kirschst.}

Facesoffungi number: FoF 05881

Taxa are saprobic or plant pathogenic (Matheis 1977, Vera \& Murray 2016, Meyer \& Luttrell 1986, 1987). Ascomata are apothecial. Apothecia are cupulate, discoid or urn-shaped and sessile or sub-stipitate. The margins are sometimes covered with pigmented hairs. The ectal excipulum is composed of pigmented cells of textura globulosa to angularis and medullary excipulum hyaline cells of textura prismatica. Paraphyses are filiform, cylindrical or lanceolate and guttulate. Asci are 8-spored, conical apex and amyloid. Ascospores are 0-3-septate, ellipsoid to long-filiform and guttulate (Matheis 1977, Vera \& Murray 2016, Smerlis 1966, Meyer \& Luttrell 1986). Asexual morphs are hyphomycetous or coelomycetous. Conidiophores are phialidic and hyaline to brown. Conidia are ellipsoid to rod-shaped or filiform with pointed apices and 0-1-septate (Walsh et al. 2018, Travadon et al. 2015, Gramaje et al. 2011, Marvanova \& Barlocher 2001, Goncalves et al. 2012, Duarte et al. 2016, Gönczöl \& Révay 2003, Goodwin 2002, King et al. 2013).

Notes - This family formed monophyletic well-supported clade with Drepanopezizaceae. According to our phylogenetic analysis, the genus Rhynchosporium showed a close relationship with this family. Similar phylogenetic placement of this genus shown in Pärtel (2016). Therefore, considering the results of our phylogeny and previous literature, we add Rhynchosporium to this family. Some taxa (e.g. Cadophora, Oculimacula) of this family are plant pathogens which cause stem rots, wood decay, trunk hypertrophy and bark cracks in economically important crops such as cereal, soybean and kiwifruit trees (Travadon et al. 2015).

Cadophora lacrimiformis Ekanayaka \& K.D. Hyde, sp. nov.

Index Fungorum number: IF556281; Facesoffungi number: FoF 05882; Fig. 19.

Etymology - refers to the tear-shaped ascospores

Holotype - MFLU 16-1486

Saprobic on dead stems. Sexual morph: Apothecia 300-500 × 140-300 $\mu \mathrm{m}$, arising singly, sessile, slightly erumpent. Receptacle cupulate, black. Disc concave, black. Ectal excipulum 16-21 $\mu \mathrm{m}(\bar{x}=20.3 \mu \mathrm{m}, \mathrm{n}=10)$ in lower flanks, composed of, thin-walled, light brown to hyaline cells of textura angularis. Medullary excipulum $7-8.5 \mu \mathrm{m}(\bar{x}=7.6 \mu \mathrm{m}, \mathrm{n}=10)$ in lower flanks, composed of, thin-walled, hyaline cells of textura porrecta. Hymenium hyaline. Paraphyses 2-4.5 $\mu \mathrm{m}$ wide $(\bar{x}=3.4 \mu \mathrm{m}, \mathrm{n}=20)$, numerous, filiform, obtuse and slightly swollen at the apex, septate, branched, smooth. Asci 65-95 × 8-11 $\mu \mathrm{m}(\bar{x}=77.4 \times 9 \mu \mathrm{m}, \mathrm{n}=30)$, 8-spored, unitunicate, cylindric-clavate, apex rounded and amyloid, short stipitate base, arising from croziers. Ascospores 10-12 $\times 4.5-6.5 \mu \mathrm{m}(\bar{x}=11.5 \times 5.6 \mu \mathrm{m}, \mathrm{n}=40), 1-2$-seriate, tear shape, fusoid to ellipsoid, one side is slightly wider than the other side, tear-shaped, sometimes 1-septate, hyaline, guttulate. Asexual morph: Undetermined.

Material examined - Russia, Rostov region, Shakhty City District, ruderalized steppe near Grushevka River, saprobic on dead stem of unidentified Brassicaceae herbal plant (perhaps, Sisymbrium altissimum L.), 18 February 2016, Timur S. Bulgakov, T-1191 (MFLU 16-1486).

GenBank accessions - LSU- MK591959, ITS- MK585003, SSU- MK585020

Notes - Our collection from Russia grouped with Cadophora antarctica (CBS 143035) and Cylindrosporium concentricum (CBS 157 35) with the statistical support of 61\% (Fig. 18).

The ITS data of our collection shows $96 \%$ similarity to that of Cadophora luteo-olivacea (ICMP:18084) (623/649-96\% with 5 gaps). The LSU data of our species shows $99 \%$ similarity to that of Cadophora luteo-olivacea (CBS 128576) (847/859-99\% with 1 gap) and Cadophora malorum (CBS 260.32) (847/859-99\% with 1 gap).

The genera Cadophora and Cylindrosporium are recorded as the asexual genera (Munkvold \& Neely 1989, Khan et al. 2017, Travadon et al. 2015). Our collection is genetically close to Cadophora and Cylindrosporium. However, morphology of our collection is similar to sexual morph characteristics of the other genera within Ploettnerulaceae (Matheis 1977, Meyer \& Luttrell 1986). Ascospores of our collection failed to germinate and we are unable to get the asexual morph of this species. 


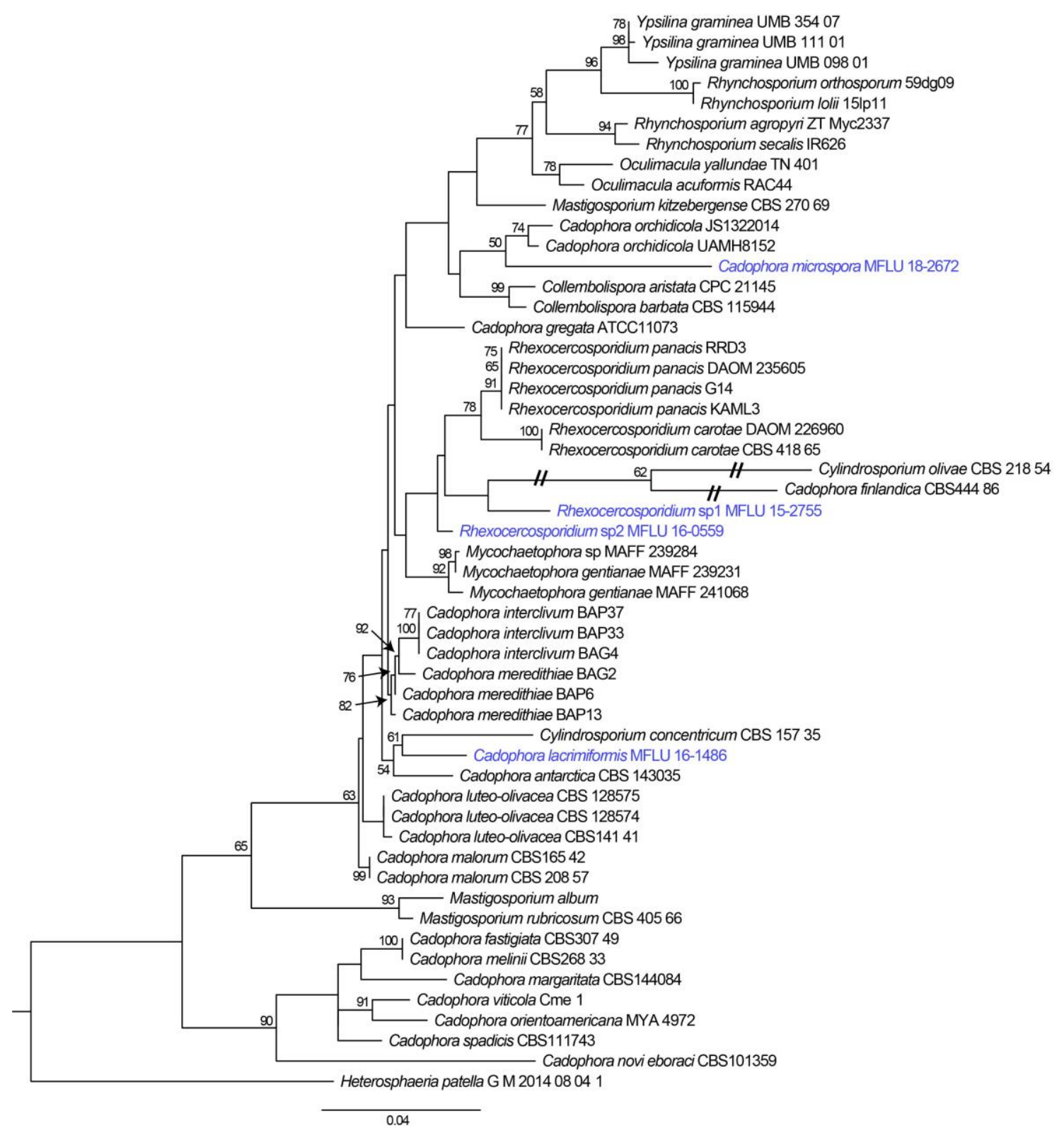

Figure 18 - Phylogram generated from maximum likelihood analysis of sequences of Ploettnerulaceae based on ITS sequence data. MLBP values $\geq 50 \%$ are given near the nodes. Strain/culture numbers are given after the taxa names. The tree is rooted with Heterosphaeria patella (G.M-2014-08-04-1).

Cadophora microspora Ekanayaka \& K.D. Hyde, sp. nov.

Index Fungorum number: IF556282; Facesoffungi number: FoF 05883; Fig. 20.

Etymology - refers to the small ascospores

Holotype - MFLU 18-2672

Saprobic on dead stems. Sexual morph: Apothecia 100-200 $\mu \mathrm{m}$ wide, arising singly or in small groups, sessile, erumpent from the substrate, black when fresh. Receptacle cupulate, disc concave, disc and the margins are black when fresh. Ectal excipulum $21-23 \mu \mathrm{m}(\bar{x}=21.7 \mu \mathrm{m}, \mathrm{n}=$ 10 ) in margins and upper flanks, 3-5 cell layers deep, cell walls are thick, blackish cells of textura globulosa. Medullary excipulum 6-8 $\mathrm{mm}(\bar{x}=7.3 \mu \mathrm{m}, \mathrm{n}=10)$ in upper flanks, composed of narrow, long, thin-walled, hyaline cells of textura epidomoidea. Hymenium hyaline. Paraphyses $1.2-1.8 \mu \mathrm{m}$ wide $(\bar{x}=1.5 \mu \mathrm{m}, \mathrm{n}=20)$, numerous, filiform, branched, septate, hyaline, acute at the apex, not exceed asci in length. Asci $31-38 \times 5-6 \mu \mathrm{m}(\bar{x}=33.8 \times 5.5 \mu \mathrm{m}, \mathrm{n}=30) 8$-spored, 
unitunicate, cylindric-clavate, rounded or medium conical at the apex, amyloid, stipitate base, arising from croziers. Ascospores 6-10 $\times 1.5-3 \mu \mathrm{m}(\bar{x}=8.1 \times 2.3 \mu \mathrm{m}, \mathrm{n}=40)$, multi-seriate, fusoid-clavate, aseptate, hyaline, with 2-3 guttules. Asexual morph: Undetermined.

Material examined - UK, Calbourne Stream, Isle of Wight, on Apiaceae stem, 11 May 2015, E.B.G. Jones, GJ 154b (MFLU 18-2672).

GenBank accessions - LSU- MK591966, ITS- MK584939, SSU- MK585027, RPB2MK373055

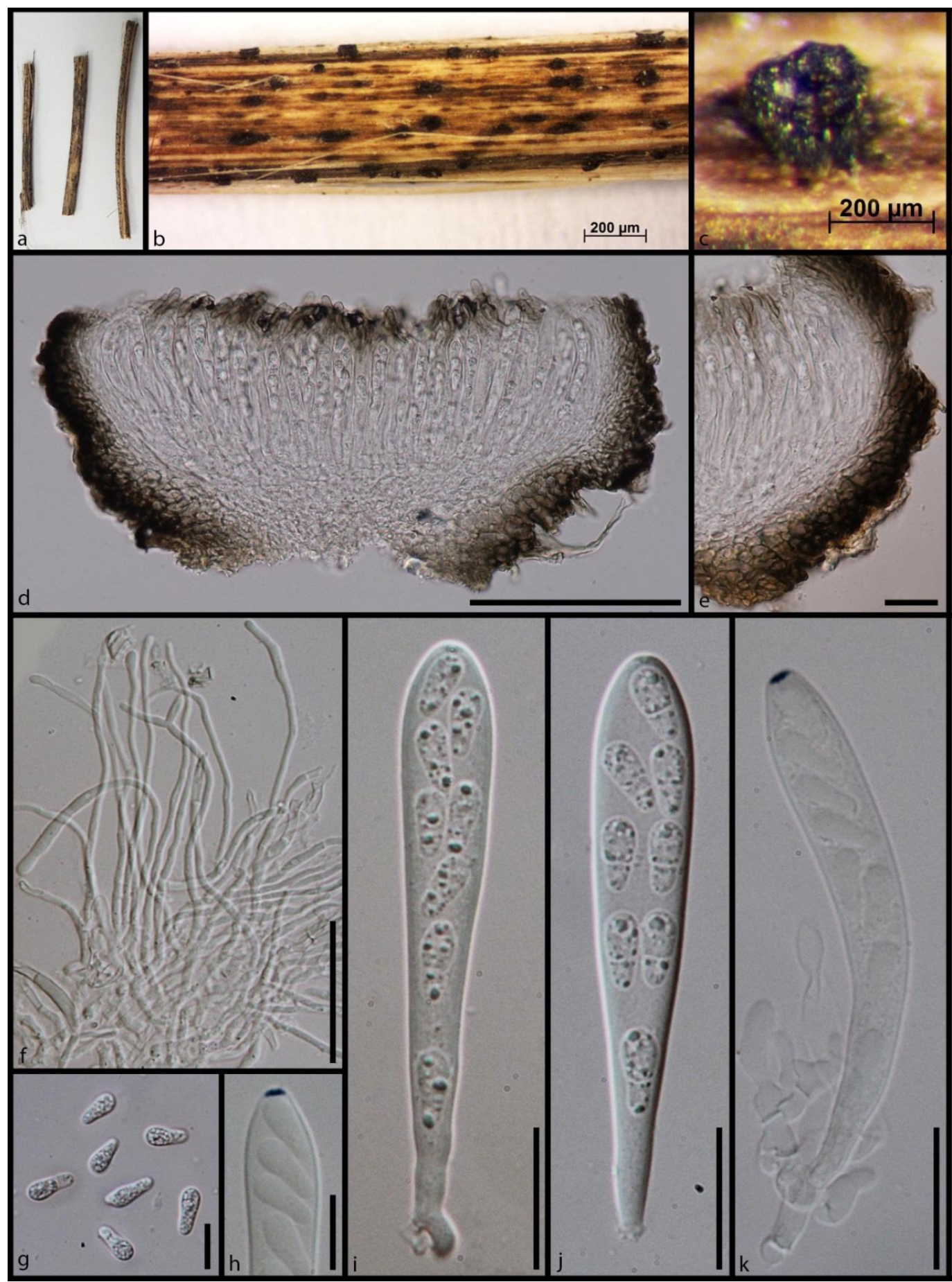

Figure 19 - Morphology of Cadophora lacrimiformis (MFLU 16-1486 holotype) a Substrate. b Apothecia on wood. c Apothecium on wood. d Cross section of an apothecium. e Close up of the cross section of apothecium at margins. f Apically swollen paraphyses. g Ascospores. $\mathrm{h}$ Amyloid ascus apex. i-k Cylindric-clavate asci. Scale bars: $\mathrm{d}=100 \mu \mathrm{m}, \mathrm{e}, \mathrm{i}-\mathrm{k}=20 \mu \mathrm{m}, \mathrm{f}=30 \mu \mathrm{m}, \mathrm{g}-\mathrm{h}=10$ $\mu \mathrm{m}$. 
Notes - Our collection from UK grouped with Cadophora orchidicola strains (JS1322014, UAMH8152) from Austria and Canada (Fig. 18) with poor statistical support (50\%) and this clade forms a sister clade to Collembolispora clade.

The ITS region of our collection is similar to that of Rhexocercosporidium panacis (G14) (551/601-92\% with 13 gaps), Rhexocercosporidium sp. (P1743) (549/602-91\% with 15 gaps) and Cadophora orchidicola (JS1322014) (546/600-91\% with 15 gaps). The LSU region of our collection is similar to Mycochaetophora gentianae (MAFF 239231) (1061/1150-92\% with 20 gaps), Rhexocercosporidium carotae (MUT:4963) (1055/1151-92\% with 25 gaps), Pirottaea brevipila (CBS 309.58) (1061/1151-92\% with 22 gaps) and to Pirottaea strigosa (CBS 308.58) (1056/1156-91\% with 25 gaps).

The genus Pirottaea is genetically related to the family Helotiaceae. However, morphology of our collection shows some similarity to the genus Pirottaea by having blackish apothecia, textura globulosa excipular cells, cylindric-clavate, amyloid asci (Dougoud et al. 2012). Moreover, some of the taxa currently placed in the genus Pirottaea were previously placed in the genus Ploettnerula, which is the type genus of Ploettnerulaceae (Dougoud et al. 2012). Furthermore, our phylogeny (Fig. 18) shows that the genus Cadophora is polyphyletic and Cadophora orchidicola may require a new generic name in near future.

Considering genetic relatedness here we keep our collection as a new species to Cadophora. A wide range of taxon sampling and sequence data from different genetic markers are required to stabilize the phylogeny of Cadophora spp.

\section{Rhexocercosporidium sp1}

Facesoffungi number: FoF 05983; Fig. 21

Saprobic on conifers. Sexual morph: Apothecia 300-350 × 400-500 $\mu$ m superficial, mostly solitary, black, closed when immature and opening by a radial split at the center of the disc at maturity. Ectal excipulum 60-65 $\mu \mathrm{m}(\bar{x}=63 \mu \mathrm{m}, \mathrm{n}=10)$ wide, comprising with cells of textura angularis, outer cells are blackish while inner cells are hyaline. Medullary excipulum 8-12 $\mu \mathrm{m}(\bar{x}$ $=11 \mu \mathrm{m}, \mathrm{n}=10$ ) in lower flanks, composed of, thin-walled, hyaline cells of textura oblita. Peridium 60-65 $\mu \mathrm{m}(\bar{x}=61 \mu \mathrm{m}, \mathrm{n}=10)$ wide, comprising with dark brown cells of textura angularis. Paraphyses 1.5-2 $\mu \mathrm{m}$ wide $(\bar{x}=2.4 \mu \mathrm{m}, \mathrm{n}=20)$, numerous, filamentous, septate, obtuse apex. Asci $60-75 \times 8-12 \mu \mathrm{m}(\bar{x}=68 \times 9 \mu \mathrm{m}, \mathrm{n}=30)$ unitunicate, cylindrical, conical and nonamyloid apex, short stipitate, arising from croziers. Ascospore not observed. Asexual morph: Undetermined.

Material examined - Russia, Arkhangelsk region, Akhangelsk City, Maimaksansky City District, saprobic on dead stem of Thalictrum flavum L. (Ranunculaceae), 22 May 2015, Gennady V. Okatov, T-588 (MFLU 15-2755).

GenBank accessions - ITS- MK584999, SSU- MK585013

Notes - Our collection from Russia grouped with Cadophora finlandica and Cylindrosporium olivae (CBS 218 54) and these three strains formed a clade basal to Rhexocercosporidium clade (Fig. 18). The ITS region of our collection is similar to that of Pirottaea senecionis (CBS 307.58) (568/593-96\% with 1 gap), Cadophora cf. olivo-luteacea (GPO_LL_01_G9) (565/590-96\% with 1 gap) and Pyrenopeziza ebuli (CBS 328.58) (569/595-96\% with 5 gaps), Cadophora luteo-olivacea (PhiK3II) (566/594-95\% with 1 gaps) and Rhexocercosporidium panacis (DAOM 235605) (566/594-95\% with 3 gaps).

The genus Pyrenopeziza genetically related to the family Mollisiaceae and Pirottaea to Helotiaceae. However, morphology of our collection shows some similarity to the genera Pyrenopeziza and Pirottaea by having blackish apothecia, textura globulosa excipular cells, cylindric-clavate, amyloid asci and ellipsoid to fusoid ascospores (Rawlinson et al. 1978, Hütter 1958, Gremmen 1958, Schüepp 1959, Crous et al. 2017, Gminder 2012, Dougoud et al. 2012).

However, in our collection we did not observe ascospores and the collection is immature. The collection did not mature after in vitro incubation. Therefore, here we name this collection as Rhexocercosporidium $\mathrm{sp} 1$. 


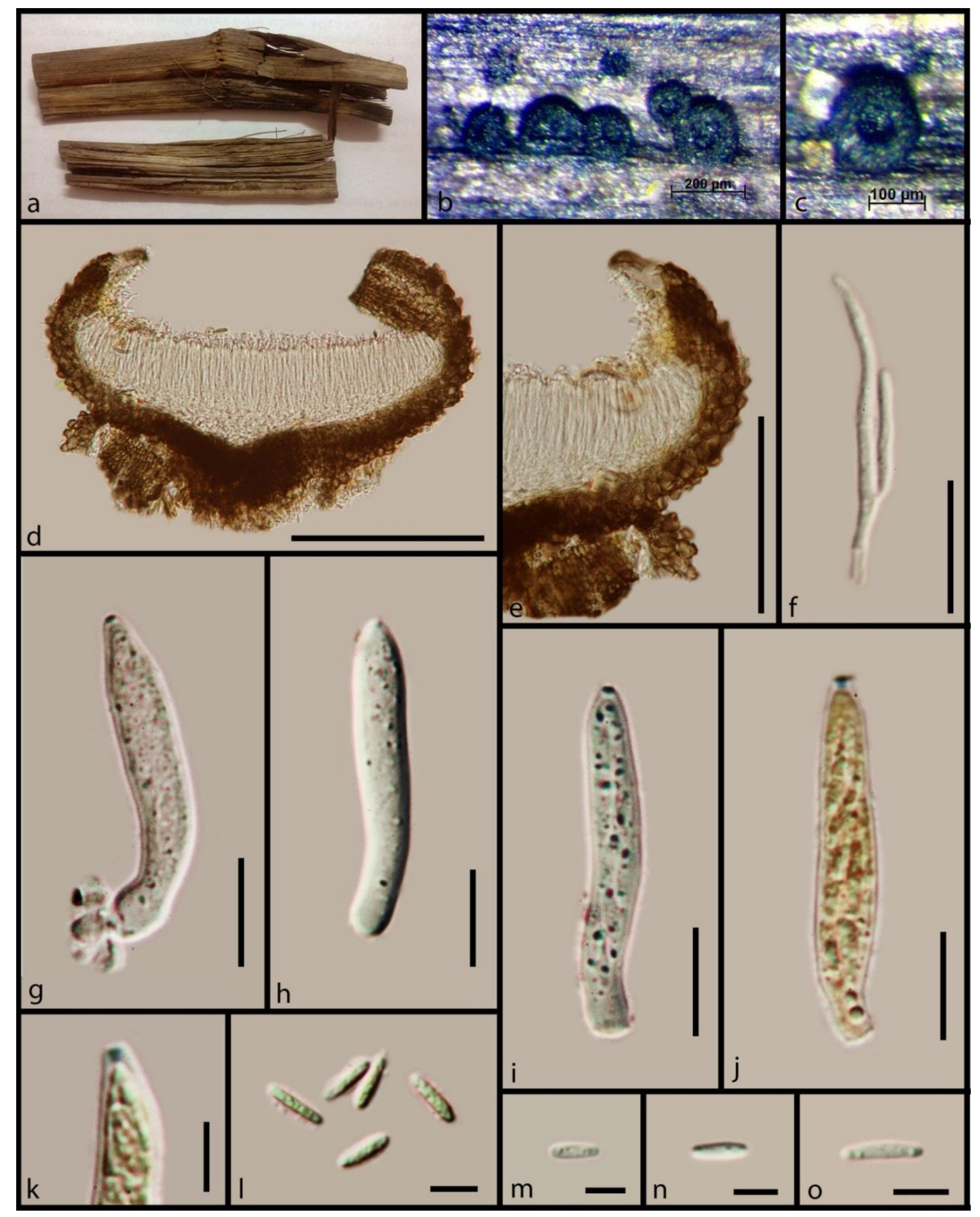

Figure 20 - Morphology of Cadophora microspora (MFLU 18-2672 holotype) a Substrate. b Apothecia on wood. c Apothecium on wood. d Cross section of an apothecium. e Vertical section of the apothecium at margin. $\mathrm{f}$ Aseptate, branched paraphyses. $\mathrm{g}-\mathrm{j}$ Cylindrical asci. $\mathrm{k}$ Amyloid ring at apical apex. 1-o Clavate ascospores. Scale bars: $b=200 \mu \mathrm{m}, \mathrm{c}=100 \mu \mathrm{m}, \mathrm{d}=70 \mu \mathrm{m}, \mathrm{e}=60 \mu \mathrm{m}$, $\mathrm{f}-\mathrm{j}=10 \mu \mathrm{m}, \mathrm{k}-\mathrm{O}=5 \mu \mathrm{m}$. 


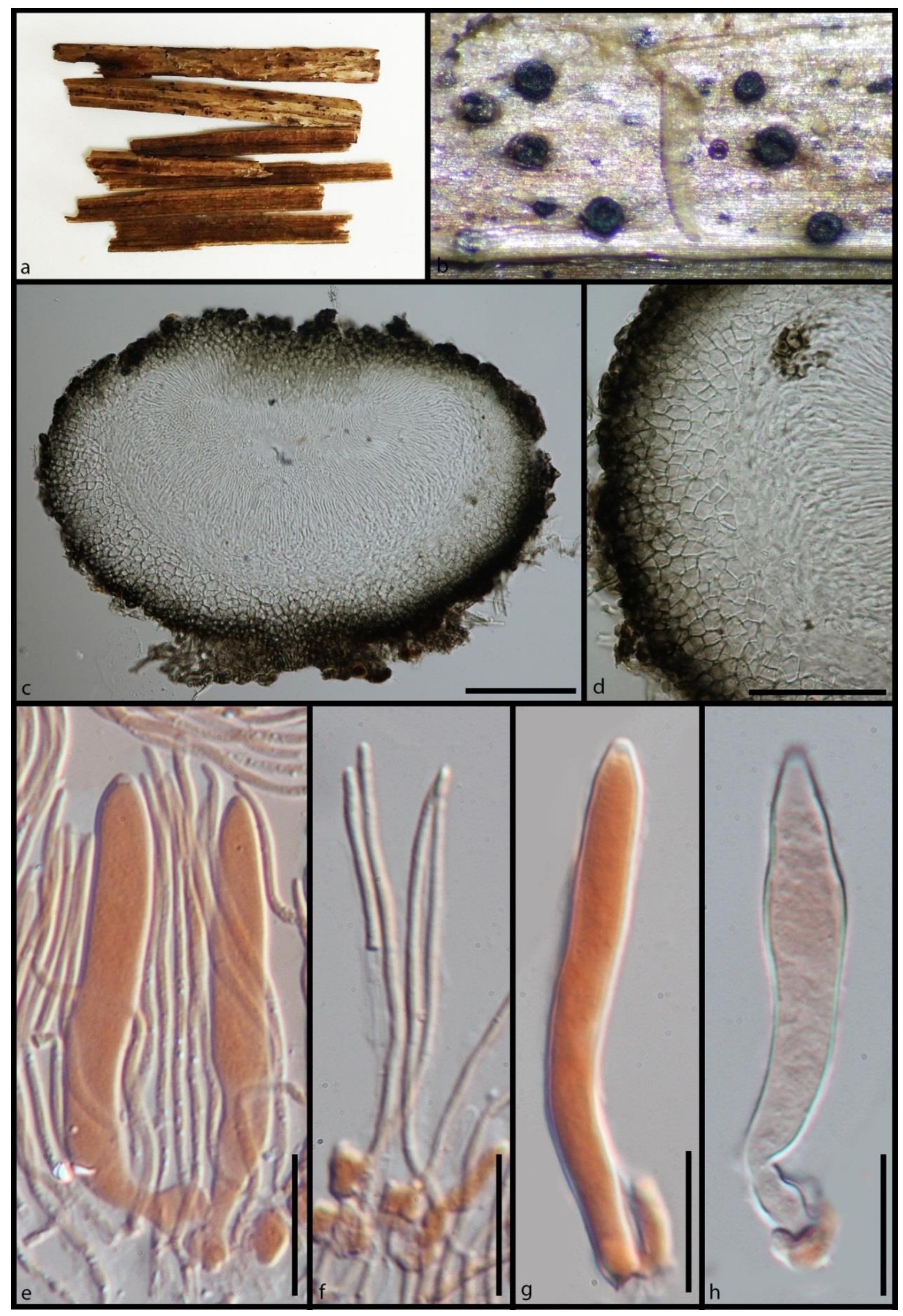

Figure 21 - Morphology of Rhexocercosporidium sp1 (MFLU 15-2755) a Substrate. b Mature apothecia on wood. c Cross section of an immature apothecium. d Close up of excipulum. e Part of hymenium showing asci and paraphyses. f Filiform paraphyses. g, h Short stipitate asci. Scale bars: $\mathrm{c}=100 \mu \mathrm{m}, \mathrm{d}=60 \mu \mathrm{m}, \mathrm{e}-\mathrm{h}=20 \mu \mathrm{m}$. 


\section{Rhexocercosporidium $\mathrm{sp2}$}

Facesoffungi number: FoF 05984; Fig. 22

Saprobic on conifers. Sexual morph: Apothecia $222-228 \times 738-743 \mu \mathrm{m}(\bar{x}=225.9 \times 741.5$ $\mu \mathrm{m}, \mathrm{n}=10)$ superficial, mostly solitary, black or brown. Receptacle cupulate. Disc concave Ectal excipulum 40-45 $\mu \mathrm{m}(\bar{x}=43 \mu \mathrm{m}, \mathrm{n}=10)$ wide at lower flanks, marginal cells are subglobose, flanks are comprising with dark brown cells of textura angularis. Medullary excipulum 10-15 $\mu \mathrm{m}$ $(\bar{x}=12 \mu \mathrm{m}, \mathrm{n}=10)$ wide at lower flanks, comprising with hyaline cells of textura porrecta. Paraphyses $2.2-2.8 \mu \mathrm{m}$ wide $(\bar{x}=2.4 \mu \mathrm{m}, \mathrm{n}=20)$, numerous, filamentous, septate, swollen at the apices. Asci 47-52 × 4-4.5 $\mu \mathrm{m}(\bar{x}=49.6 \times 4.3 \mu \mathrm{m}, \mathrm{n}=30) 8$-spored, unitunicate, cylindrical, apex conical and amyloid, base stipitate, croziers absent. Ascospore $6-9 \times 2-3 \mu \mathrm{m}(\bar{x}=8.5 \times 2.7 \mu \mathrm{m}, \mathrm{n}$ $=40$ ), ellipsoid, hyaline, non septate, smooth walled. Asexual morph: Undetermined.

Material examined - UK, New Forest, Hants, 24 November 2014, E. B. G. Jones, GJ073/UK01 (MFLU 16-0559).

GenBank accessions - LSU- MK591961, ITS- MK584945, SSU- MK585022, TEFMK637048, RPB2- MK368612

Notes - Our collection from UK grouped basal to Cadophora finlandicaRhexocercosporidium clade (Fig. 18). The ITS region of our collection is similar to that of Pyrenopeziza ebuli (CBS 328.58) (903/913-99\% with 3 gaps), Pirottaea brevipila (CBS 309.58) (867/915-95\% with 7 gaps), Cadophora luteo-olivacea (Clo0316) (836/893-94\% with 3 gaps), Rhynchosporium secalis (isolate 763) (826/914-90\% with 13 gaps) and Rhynchosporium agropyri (isolate 04CH-RAC-A.6.1) (823/914-90\% with 14 gaps). The LSU data of our species shows similarity to that of Cadophora luteo-olivacea (CBS 128576) (846/854-99\% with no gaps), Cadophora malorum (CBS 260.32) (846/854-99\% with no gaps), Pyrenopeziza lonicerae (CBS $332.58)(846 / 854-99 \%$ with no gaps) and Pyrenopeziza chamaenerii (CBS 327.58) (846/854-99\% with no gaps).

The genus Cadophora has morphological and genetic relationship with the genus Pyrenopeziza as described in the notes of above Rhexocercosporidium collection.

This collection distinct from other recorded sexual morphs of Cadophora and Rhexocercosporidium (present study) by having apically swollen paraphyses. However, the statistical support for the placement of this collection is low. Therefore, here we keep this collection as Rhexocercosporidium sp. 2 until we have more data to stabilize its phylogenetic position.

\section{Vibrisseaceae Korf}

Facesoffungi number: FoF 05884

Taxa are saprobic on dead plant material in aquatic and semi-aquatic environments. Ascomata are apothecial and characterized by sessile to stipitate, cupulate or clavate receptacle. The ectal excipulum is composed of hyaline to brown, thin- or thick-walled cells of textura angularis to globulosa and medullary excipulum reduced or composed of textura oblita. Paraphyses are apically slightly swollen, sometimes branched and filiform. Asci are 8-spored, cylindric-clavate, long stipitate, sometimes amyloid and arising from croziers. Ascospores are filiform, 3-24-septate and partly fragmenting (Sanchez 1967, Sánchez \& Korf 1966, Beaton \& Weste 1980, 1983, Almeida et al. 2015, Seaver 1946, De Notaris 1863, Hustad \& Miller 2011, Iturriaga \& Korf 1990). Asexual morphs are hyphomycetous, phialidic and acervulus. Conidiophores are straight, cylindrical, hyaline and sometimes branched. Conidiogenous cells are holoblastic or polytretic. Conidia are ellipsoid or irregular in shape and unicellular or up to 7septate (Hernandez-Restrepo et al. 2017, 2012, Shenoy et al. 2010, Kirschner \& Oberwinkler 2001, Goh et al. 1998, Goh \& Hyde 1998, Legon 2012, Crous et al. 2015, Iturriaga \& Israel 1985).

Notes - This family forms a monophyletic clade close to the family Mollisiaceae. According to our phylogenetic analysis we observed the close relationship of the genera Acephala, Cheirospora, Diplococcium, Gorgoniceps and Strossmayeria to Vibrisseaceae. Hustad \& Miller (2011) also showed the similar phylogenetic placement of these taxa within their phylogenetic 
analysis. Moreover Shenoy et al. (2010) showed that the Diplococcium and Vibrissea are genetically closely related. Within the phylogenetic analysis provided by Crous et al. (2015), the genera Diplococcium, Acephala and Cheirospora formed a monophyletic clade. Therefore, by considering the results our study and previous literature we placed the genera Acephala, Cheirospora, Diplococcium, Gorgoniceps and Strossmayeria, under the family Vibrisseaceae. Moreover, we removed Chlorovibrissea from this family as it is phylogenetically unrelated to Vibrisseaceae according to the results of our analyses and our results are in agreement with the results provided by Hustad \& Miller (2011).

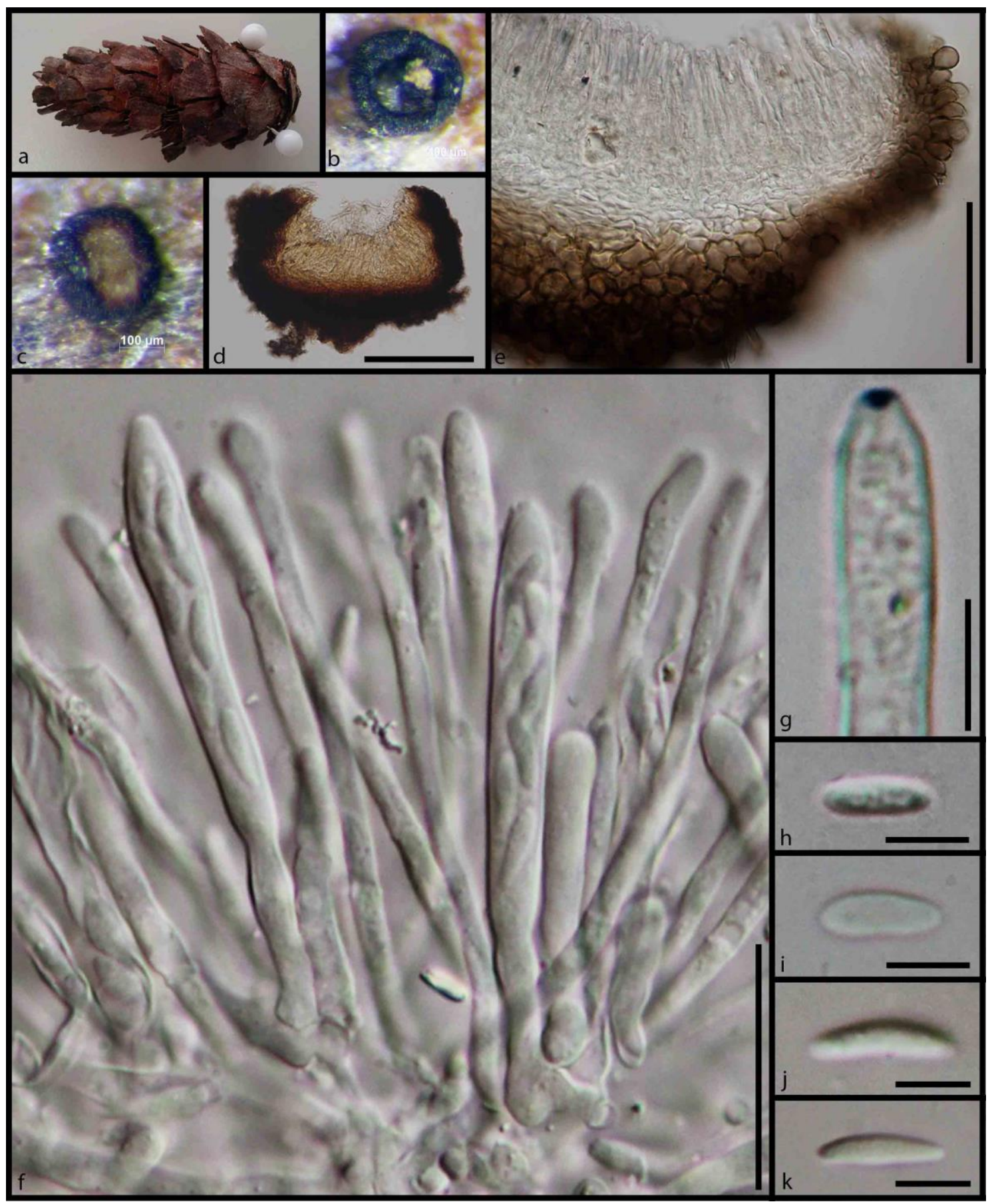

Figure 22 - Morphology of Rhexocercosporidium sp2 (MFLU 16-0559) a Substrate. b, c Mature apothecia on wood. d Cross section of an apothecium. e Close up of the excipulum. $f$ Asci and paraphyses. g Amyloid apex in Melzer's reagent. h-k Ellipsoid ascospores. Scale bars: $d=100 \mu \mathrm{m}$, $\mathrm{e}=70 \mu \mathrm{m}, \mathrm{f}=20 \mu \mathrm{m}, \mathrm{g}=10 \mu \mathrm{m}, \mathrm{h}-\mathrm{k}=5 \mu \mathrm{m}$. 


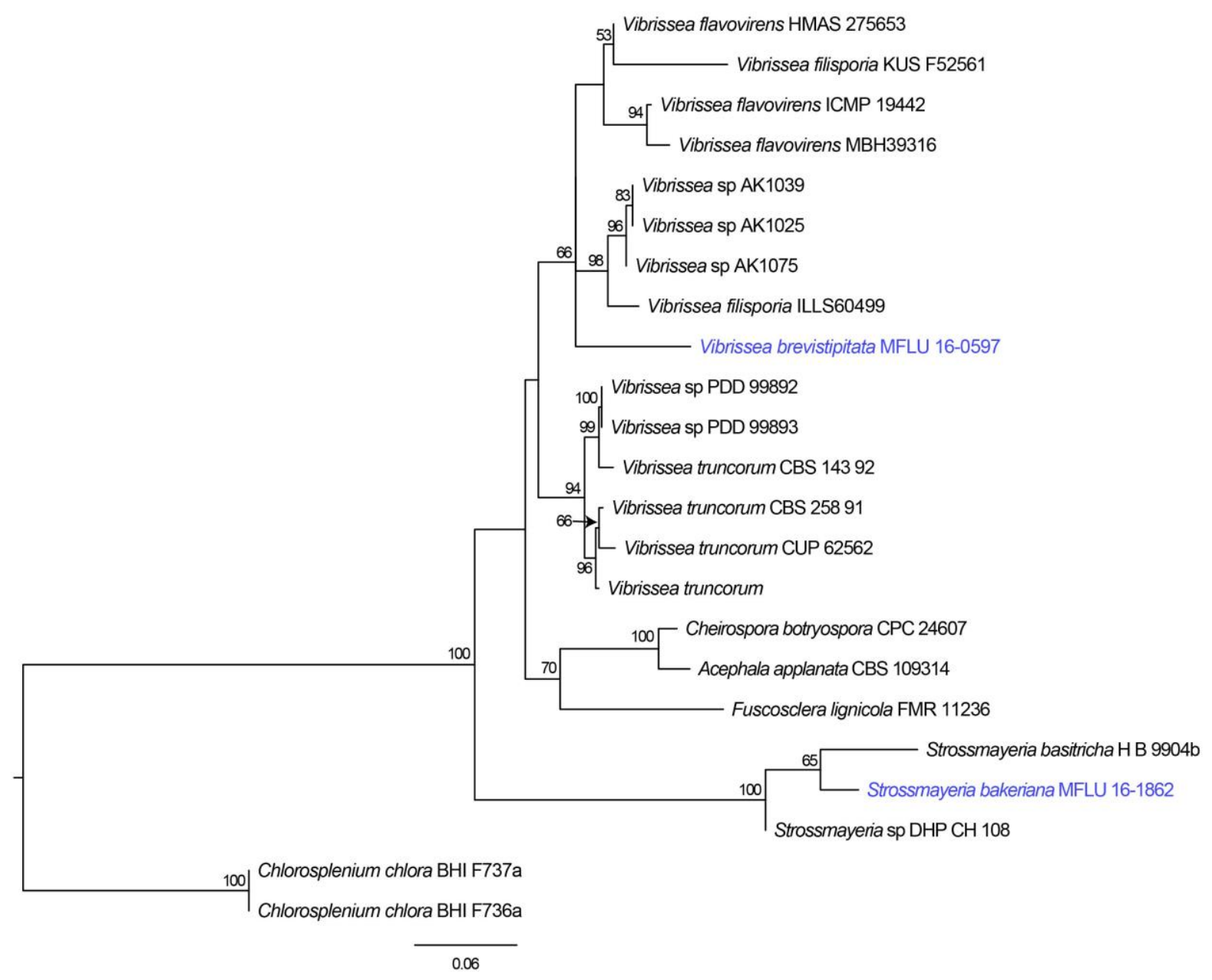

Figure 23 - Phylogram generated from maximum likelihood analysis of sequences of Vibrissea (Vibrisseaceae) based on ITS sequence data. MLBP values $\geq 50 \%$ are given near the nodes. Strain/culture numbers are given after the taxa. The tree is rooted with Chlorosplenium chlora (BHI F737a and BHI F736a).

Vibrissea brevistipitata Ekanayaka \& K.D. Hyde, sp. nov.

Index Fungorum number: IF556283; Facesoffungi number: FoF 05885; Fig. 24.

Etymology - Refers to short stipitate apothecia

Holotype - MFLU 16-0597

Saprobic on dead leaf. Sexual morph: Apothecia 300-400 $\times 400-460 \mu \mathrm{m}$, arising singly, stipitate. Receptacle cupulate, black when dry. Disc concave. Ectal excipulum 25-30 $\mu \mathrm{m}(\bar{x}=20.3$ $\mu \mathrm{m}, \mathrm{n}=10$ ) in lower flanks, composed of, thin-walled, brown cells of textura angularis to globulosa. Medullary excipulum $10-15 \mu \mathrm{m}(\bar{x}=13 \mu \mathrm{m}, \mathrm{n}=10)$ in lower flanks, composed of, thin-walled, hyaline cells of textura oblita. Hymenium hyaline. Paraphyses $3-5 \mu \mathrm{m}$ wide $(\bar{x}=3.8$ $\mu \mathrm{m}, \mathrm{n}=20$ ) at the apex, numerous, filiform, obtuse and slightly swollen at the apex, aseptate, exceeding the asci in length, smooth. Asci $150-200 \times 5-10 \mu \mathrm{m}(\bar{x}=184 \times 8 \mu \mathrm{m}, \mathrm{n}=30) 8$-spored, unitunicate, cylindric-clavate, rounded apex, non-amyloid, tapered and long stipitate base, croziers absent. Ascospores 120-150 × 1.4-2 $\mu \mathrm{m}(\bar{x}=135 \times 1.7 \mu \mathrm{m}, \mathrm{n}=40), 1-2$-seriate, fusoid, threadlike, aseptate, hyaline. Asexual morph: Undetermined.

Material examined - Italy, Forlì-Cesena Province [FC], Fiumicello di Premilcuore, on dead land leaf of Quercus sp., 10 February 2014, Erio Camporesi, IT1718 (MFLU 16-0597).

GenBank accessions - ITS- MK584980

Notes - Our collection of Vibrissea clustered basal to Vibrissea filisporia- Vibrissea flavovirens clade with statistical support of $66 \%$ (Fig. 23). The ITS data of our collection is similar 
to that of Vibrissea filisporia (JLF2084) (517/557-93\% with 4 gaps) and to Vibrissea truncorum (JLF2113) (513/558-92\% with 5 gaps).

Our species is phylogenetically close to $V$. filisporia, but $V$. filisporia differs in having bluishgrey, yellow or ochraceous disc and septate paraphyses. Vibrissea norvegica is similar in having simple paraphyses, but differs in having shorter ascospores (Sanchez 1966). Vibrissea sporogyra differs in having branched paraphyses (Sanchez \& korf 1966). Vibrissea decolorans differs in having amyloid asci (Sanchez 1966). Vibrissea albofusca differs in having long stipitate apothecia (Beaton \& Weste 1983).

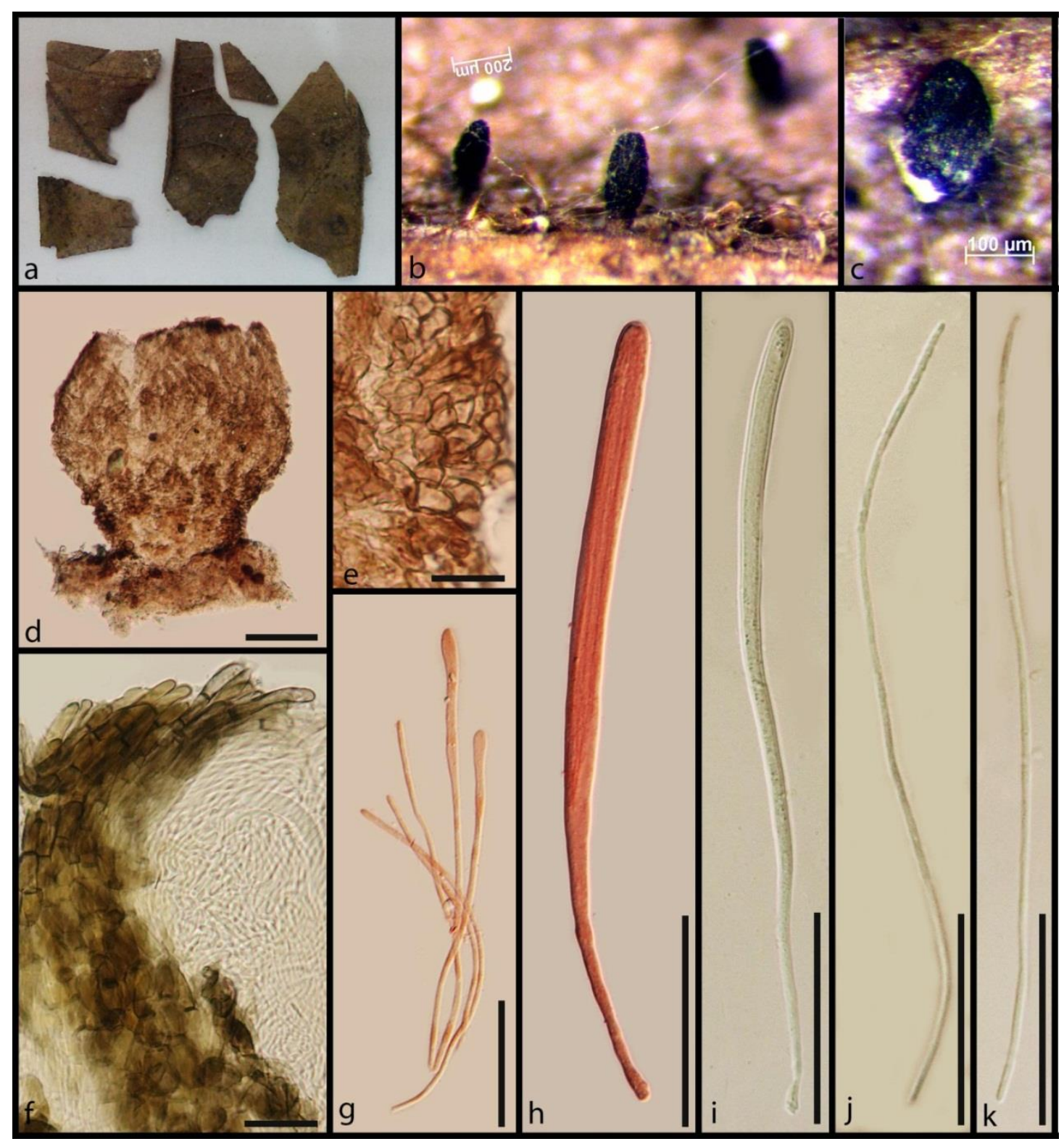

Figure 24 - Morphology of Vibrissea brevistipitata (MFLU 16-0597 holotype) a Substrate. b, c Apothecia on leaf surface. d Cross section of an apothecium. e Close up of the cross section of apothecium at flanks. $f$ Close up of the cross section of apothecium at flanks. $g$ Filiform paraphyses. $\mathrm{h}-\mathrm{i}$ Cylindric-clavate asci. $\mathrm{j}-\mathrm{k}$ Thread-like ascospores. Scale bars: $\mathrm{d}=100 \mu \mathrm{m}, \mathrm{e}-\mathrm{f}=$ $20 \mu \mathrm{m}, \mathrm{g}=30 \mu \mathrm{m}, \mathrm{h}-\mathrm{i}=50 \mu \mathrm{m}, \mathrm{j}-\mathrm{k}=30 \mu \mathrm{m}$.

\section{Strossmayeria bakeriana (Henn.) Iturr.}

Facesoffungi number: FoF 05886; Fig. 25.

Saprobic on dead stems. Sexual morph: $408-434 \times 170-200 \mu \mathrm{m}(\bar{x}=425.7 \times 198.3 \mu \mathrm{m}, \mathrm{n}$ $=10)$ Apothecia arising in small groups, sessile or sub-stipitate. Receptacle turbinate, disc convex 
and whitish to brownish, margins crenulate. Ectal excipulum 16-22 $\mu \mathrm{m}(\bar{x}=20.3 \mu \mathrm{m}, \mathrm{n}=10)$ in lower flanks, composed of, thin-walled, brown to hyaline cells of textura prismatica. Medullary excipulum 26-32 $\mu \mathrm{m}(\bar{x}=30 \mu \mathrm{m}, \mathrm{n}=10)$ in lower flanks, composed of, thin-walled, hyaline cells of textura prismatica. Hymenium hyaline. Paraphyses $2.3-3.8 \mu \mathrm{m}$ wide $(\bar{x}=3.1 \mu \mathrm{m}, \mathrm{n}=20)$, numerous, filiform, obtuse and slightly swollen at the apex, aseptate, not exceeding the asci in length, smooth, aguttulate. Asci 95-110 × 12.5-17 $\mu \mathrm{m}(\bar{x}=102 \times 15 \mu \mathrm{m}, \mathrm{n}=30)$ 8-spored, unitunicate, cylindric-clavate, conical at the apex, amyloid ring present at the ascus apex, stipitate base, croziers absent. Ascospores 27-44 × 3.5-5.6 $\mu \mathrm{m}(\bar{x}=34.5 \times 4.6 \mu \mathrm{m}, \mathrm{n}=40), 1-2$-seriate, fusoid, 1-6 septate, hyaline with gelatinous sheath. Asexual morph: Undetermined.

Material examined - Thailand, Chiang Mai Province, Mushroom Research Center, on dead stems, 19 July 2015, A.H. Ekanayaka, H 1/HD032 (MFLU 16-1862).

GenBank accessions - LSU- MK591971, ITS- MK584964, SSU- MK585032, RPB2MK614732

Notes - Our collection from Thailand grouped with Strossmayeria basitricha ILLS60498 with the statistical support of $65 \%$ (Fig. 23). The ITS data of our collection is similar to that of Strossmayeria sp. (DHP-CH-108) (355/365-97\% with 3 gaps), Strossmayeria basitricha (H.B. 9904b) (537/571-94\% with 10 gaps) and to Durella connivens (G.M. 2014-08-12) (495/552-90\% with 14 gaps). The LSU data shows similarity to that of Strossmayeria basitricha (ANM 2055) (770/781-99\% with 4 gaps).

Strossmayeria bakeriana is characterized by pale brown to grey, turbinate apothecia, clavate asci and hyaline, 5-7-septate ascospores with gel sheath. Morphology of our collection is similar to the description from Iturriaga \& Korf (1990).

\section{Chlorospleniaceae Ekanayaka \& K.D. Hyde, fam. nov.}

Index Fungorum number: IF556284; Facesoffungi number: FoF 05887

Type genus - Chlorosplenium

Saprobic on well-decayed plant material. Sexual morphs: Ascomata apothecial, cupulate or discoid, sessile or substipitate, disc whitish, yellowish, greyish or greenish, receptacle yellow or greenish. Ectal excipulum composed of brownish cells of textura angularis. Medullary excipulum composed of thick hyaline cells of textura intricata. Paraphyses filiform, septate. Asci 8-spored, cylindric-clavate, amyloid. Ascospores ellipsoid to fusoid, hyaline and smooth walled. Asexual morphs: not recorded.

Notes - Previously most of the greenish inoperculate discomycetes were assigned to the genus Chlorosplenium (Dixon 1974). However, now many of them are synonymized to the genus Chlorociboria (Wang 2007). Currently around ten species are assigned to the genus Chlorosplenium (Index fungorum 2018, Jaklitsch et al. 2016). Within our phylogenetic analysis this genus formed a separate clade close to Vibrisseaceae and this clade is highly statistically supported (100\%- MLBP and 1-BYPP). The sister relationship of new family with MollisiaceaeVibrisseaceae clade received the statistical support of $72 \%$ (MLBP).

Discinellaceae Ekanayaka \& K.D. Hyde, fam. nov.

Index Fungorum number: IF556285; Facesoffungi number: FoF 05888

Type genus - Discinella

Saprobic on dead plant material. Sexual morphs: Ascomata apothecial discoid to cupulate, circular in shape, gelatinous, margin smooth or sometimes covered with hairs. Ectal excipulum composed of gelatinous hyaline cells of textura prismatica or textura porrecta. Medullary excipulum composed of cells of textura intricata to prismatica. Paraphyses filiform, branched at the apices. Asci 8-spored, cylindrical, sometimes arising from croziers, amyloid or non-amyloid. Ascospores ellipsoid, aseptate, hyaline, without sheath. Asexual morphs: Conidiomata hyphomycetous, holoblastic. Conidia mostly hyaline, sometimes branched, filiform, globose, or fusoid some form dimorphic conidia. 
Notes - According to our phylogenetic analysis, the genera Discinella, Pezoloma, Gyoerffyella, Articulospora, Lemonniera and Naevala formed a monophyletic well-supported clade (98\%- MLBP support and 1-BYPP) sister to Godroniaceae-Mitrulaceae clade. However, the sister relationship is not statistically supported. Same phylogenetic placement of these genera is recorded in Baral et al. (2013a, b) and Sri-indrasutdhi et al. (2015). Therefore, considering the results of our phylogeny and previous literature, we introduce the new family.

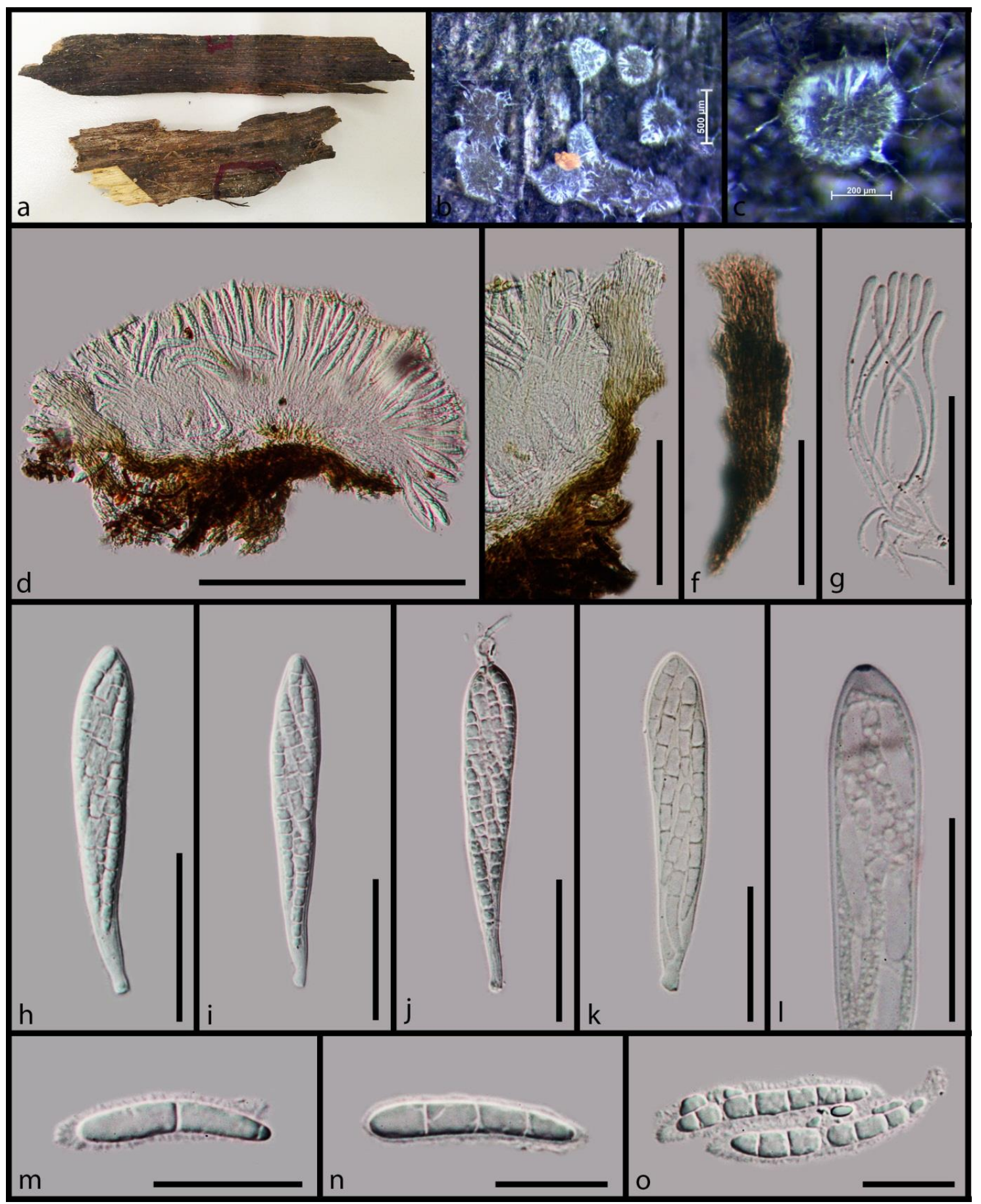

Figure 25 - Morphology of Strossmayeria bakeriana (MFLU 16-1862) a Substrate. b Apothecia on wood. c Apothecium on wood. d Cross section of an apothecium. e Close up of the cross section of apothecium at margins. f Pigmented excipular cells. g Cylindrical paraphyses. h-k Cylindricclavate asci. 1 Apex of the asci with the plug blueing in Melzer's reagent. $\mathrm{m}-\mathrm{o}$ Fusoid ascospores. Scale bars: $\mathrm{b}=500 \mu \mathrm{m}, \mathrm{c}=200 \mu \mathrm{m}, \mathrm{d}=300 \mu \mathrm{m}, \mathrm{e}-\mathrm{f}=100 \mu \mathrm{m}, \mathrm{g}=50 \mu \mathrm{m}, \mathrm{h}-\mathrm{l}=40 \mu \mathrm{m}, \mathrm{m}-\mathrm{o}=20$ $\mu \mathrm{m}$. 


\section{Godroniaceae Baral}

Facesoffungi number: FoF 05889

Taxa are plant pathogenic (Groves 1968, Müller \& Dorworth 1983, Jeger et al. 2017, Stromeng \& Stensvand 2011, CABI 2017, Funk 1977). Ascomata are apothecial and characterized by urceolate, discoid or cupulate receptacle which is, mostly stromatic and erumpent. The margins are even or slightly lobed and sometimes covered with hairs. The ectal excipulum is composed of cells of textura prismatica to angularis and medullary excipulum is composed of textura epidermoidea, prismatica to porrecta. The hymenium is flat or slightly concave and blackish. Paraphyses are filiform, simple or branched, sometimes slightly swollen at the apex and sometimes lanceolate. Asci are 8-spored, cylindric-clavate and amyloid or non-amyloid. Ascospores are fusoid, hyaline, septate and guttulate (CABI 2017, Groves 1965, 1968, Stromeng \& Stensvand 2011, Funk 1977). Asexual morphs are stromatic pycnidial and mostly associated with ascomata. Conidiogenesis is phialidic and conidia are ellipsoid to fusoid or vermiform, straight or curved, tapering towards the apices and septate (Groves 1965, 1968, Müller \& Dorworth 1983, Jeger et al. 2017, Stromeng \& Stensvand 2011, CABI 2017, Funk 1977, Sieber \& Kowalski 1993).

Notes - Godroniaceae is a plant pathogenic family. In our phylogenetic analysis this family formed a monophyletic clade sister to Arachnopezizaceae. Taxa of this family are plant pathogenic which cause shoot blight and stem canker on vascular plants (Groves 1968, Müller \& Dorworth 1983, Jeger et al. 2017, Stromeng \& Stensvand 2011, CABI 2017, Funk 1977, Chastagner et al. 2017).

Hydrocinaceae Ekanayaka \& K.D. Hyde, fam. nov.

Index Fungorum number: IF556286; Facesoffungi number: FoF 05890

Type genus - Hydrocina

Saprobic on dead plant material in aquatic and terrestrial habitats. Sexual morphs: Ascomata apothecial cupulate, sessile or substipitate. Ectal excipulum composed of cells of textura globulosa. Medullary excipulum composed of cells of textura porrecta-intricata-oblita. Paraphyses filiform, septate, branched, slightly swollen at the apices. Asci 8-spored, cylindric-clavate, amyloid, arising from croziers. Ascospores ellipsoid to fusoid, aseptate or septate, hyaline. Asexual morphs: Conidiomata hyphomycetous. Conidiophores long, hyaline, simple or branched, filiform. Conidiogenous cells proliferate sympodial. Conidia filiform, branched, sometimes septate and fragment into microconidia.

Notes - This clade mostly includes many aquatic hyphomycetes. According to our phylogenetic analysis this family formed monophyletic clade close to Heterosphaeriaceae. The clade received strong statistical support (0.97- BYPP / 59- MLBP). However, the sister relationship between the new family and Heterosphaeriaceae-Ploettnerulaceae clade is not statistically supported. Baschien et al. (2013) also showed the close phylogenetic relationship of the genera Hydrocina, Filosporella, Varicosporium within Leotiomycetes. Therefore, considering previous literature and our results here we introduce the new family Hydrocinaceae.

Bryoglossaceae Ekanayaka \& K.D. Hyde, fam. nov.

Index Fungorum number: IF556287; Facesoffungi number: FoF 05891

Type genus - Bryoglossum

Saprobic on dead plant material or parasitic on bryophytes. Sexual morphs: Ascomata apothecial, clavate to capitate or cupulate to turbinate, long stipitate, gelatinous, hymenium flat or convex, yellowish. Ectal excipulum composed of cells of textura porrecta. Medullary excipulum composed of cells of textura intricata. Paraphyses filiform, swollen at the apex. Asci 8-spored, amyloid or non-amyloid, arising from croziers. Ascospores ellipsoid to fusoid, straight, aseptate, guttulate. Asexual morphs: not recorded.

Notes - Within our phylogenetic analysis, the genera Bryoclaviculus, Bryoglossum and Neocudoniella formed a monophyletic clade sister to Godroniaceae. The clade is supported by strong statistical support (1- BYPP / 100- MLBP). However, the sister relationship is not 
statistically supported. Jaklitsch et al. (2016) also discussed the close genetic relationship of these genera within Helotiales. In here we introduce the new family Bryoglossaceae to accommodate the genera Bryoclaviculus, Bryoglossum and Neocudoniella.

\section{Hyaloscyphaceae Nannf.}

Facesoffungi number: FoF 05892

Taxa are saprobic on dead plant material. Ascomata are apothecial and rarely perithecial. Apothecia are cupulate to discoid and sessile or stipitate. The margins are covered by hairs and hairs are smooth or granulate, cylindrical, tapered to the apex, septate and straight to flexuous or hooked. The ectal excipulum is composed of cells of textura angularis, prismatica or oblita and medullary excipulum is composed gelatinous loosely arranged hyphae. Paraphyses are filiform, cylindrical or lanceolate, septate or aseptate and simple or branched. Asci are 4-8-spored, amyloid or non-amyloid and sometimes arising from croziers. Ascospores are globose, ellipsoid or fusoid, aseptate or 1-3-septate and guttulate (Jaklitsch et al. 2016, Baral et al. 2009, Han et al. 2011, Quijada et al. 2017). Asexual morphs are hyphomycetous. Conidiogenesis is phialidic or sporodochial. Conidia are aseptate, hyaline or brown, branched and muriform or in chains (Jaklitsch et al. 2016).

Notes - Hyaloscyphaceae formed a monophyletic clade close to Arachnopezizaceae within our phylogenetic analysis.

\section{Phialocephala urceolata clade}

Facesoffungi number: FoF 05893

Taxa are endophytic or saprobic. Sexual morphs are not recorded. Asexual morphs are hyphomycetous. Conidiophores are hyaline to darkly pigmented, septate and mononematous. Conidiogenesis is phialidic and conidiogenous cells are flask to urn-shaped and each with a prominent cylindrical and hyaline collarette. Conidia are globose, pedicellate and single or adhering in small clusters at the phialide apex (Wang et al. 2009).

Notes - The genus Phialocephala is polyphyletic. In our phylogenetic analysis $P$. urceolata formed a separate clade while $P$. scopiformis clustered with other taxa in the family. Moreover Wang et al. (2009) discussed that P. urceolata differs from others in the genus by having curved, urn-shaped phialides and their irregular and sometimes sparse arrangement on the conidiophore axis.

\section{Peltigeromyces clade}

Facesoffungi number: FoF 05894

Taxa are saprobic. Ascomata are apothecial, cartilaginous, thin, with a large variety of lobes (Möller 1901). Records are not available for micro morphological characters and for asexual morphs.

Notes - Previously this genus was classified under Helotiales genera incertae sedis (Wijayawardene et al. 2018). Pärtel (2016) suggested its position within Ploettnerulaceae. Within our phylogenetic analysis this genus formed a separate well supported clade close to Ploettnerulaceae-Drepanopezizaceae clade.

Amicodiscaceae Ekanayaka \& K.D. Hyde, fam. nov.

Index Fungorum number: IF556288; Facesoffungi number: FoF 05895

Type genus - Amicodisca

Saprobic on dead plant material. Sexual morphs: Ascomata apothecial, cupulate, sessile or sub-stipitate, margins covered by hairs. Hairs smooth, cylindrical, tapered to the apex, septate. Ectal excipulum composed of cells of textura angularis or textura prismatica. Medullary excipulum composed gelatinous loosely arranged hyphae. Paraphyses filiform, cylindrical, septate, simple. Asci 8-spored, amyloid, sometimes arising from croziers. Ascospores ellipsoid to fusoid, aseptate, guttulate, lemon-yellow pigmented. Asexual morphs: Conidiomata hyphomycetous, stromatic. 
Conidiophores with hyaline to cinnamon-coloured glistening slimy heads, straight or flexuous, dark brown and thick-walled except at the apex. Conidiogenous cells terminal, cylindrical, proliferating sympodially. Conidia cylindrical to cylindric-ellipsoidal, hyaline, aseptate, thin- and smoothwalled.

Notes - The genera Amicodisca and Dematioscypha was previously assigned to Hyaloscyphaceae. However, Fehrer et al. (2019) showed the separate position of Amicodisca and Dematioscypha away from Hyaloscyphaceae. Moreover, in our phylogeny these two genera formed a monophyletic clade close to Bryoglossaceae in a clade supported by one of BYPP and $100 \%$ of MLBP. Therefore, considering previous literature and results of our study, we introduce the new family Amicodiscaceae.

\section{Aquapoterium- Unguicularia clade}

Facesoffungi number: FoF 05985

Taxa are saprobic on dead plant material. Ascomata are apothecial and characterized by sessile or stipitate, cupulate receptacle. The margins are sometimes covered with short cylindrical hairs with pointed apices and basal lumen. The ectal excipulum is composed of cells of textura prismatica or a single layer of parallel hyphae with enlarged, globose apices and medullary excipulum reduced or composed of loosely arranged hyphae. Paraphyses are hyaline, filiform, obtuse to clavate at apex, septate, smooth-walled and simple or branched. Asci are 8-spored, amyloid or non-amyloid and cylindric-clavate. Ascospores are hyaline, smooth-walled, 0-1-septate, ellipsoid to clavate-cylindric and surrounded by a gelatinous sheath (Huhtinen 1985, Inman et al. 1992, Raja et al. 2008). Asexual morphs are not recorded.

Notes - Unguicularia previously placed in Hyaloscyphaceae and Aquapoterium is included to Helotiales genera incertae sedis. In our phylogeny these two genera formed a monophyletic, independent clade close to Hydrocinaceae. Similar phylogenetic position of Aquapoterium showed in the phylogeny of Raja et al. (2008). Therefore, regarding previous literature and results of our study, we placed these genera Aquapoterium and Unguicularia in a separate clade.

\section{Helotiaceae Rehm \\ $=$ Roesleriaceae Y.J. Yao \& Spooner}

Facesoffungi number: FoF 05896

Taxa are saprobic, endophytic or plant parasitic. Ascomata are apothecial and characterized by sessile or stipitate, cupulate, discoid, capitate to clavate, turbinate or globose receptacle. The margins and flanks are smooth or covered with hairs and hairs are brownish, smooth and septate or aseptate. The ectal excipulum is composed of cells of hyaline, rarely brown textura prismatica, textura intricata, textura globulosa-angularis, or textura oblita and medullary excipulum is composed of cells of textura intricata or textura porrecta. Paraphyses are sometimes absent and when present, they are cylindrical, septate or aseptate, hyaline to yellowish and guttulate. Asci are 4-8-spored, cylindric-clavate, amyloid or non-amyloid and sometimes arising from croziers. Asci are rarely opening by splitting or evanescent. Ascospores are ellipsoid, fusoid or filiform, 1-3septate and rarely ornamented (Reid 1986, Sydow 1924, Jaklitsch et al. 2016, Zheng \& Zhuang 2015, 2016, Chlebická \& Konvalinková 2010, Yao \& Spooner 1999, Johnston et al. 2014, Spooner 1987, Chlebická \& Chlebicki 2007). Asexual morphs are hyphomycetous, sporodochial or synnematal. Macroconidia are holoblastic, hyaline, filiform or staurosporous, dark brown, in chains, bulbils or solitary on conidiophores and 3-5-septate. Microconidia are phialidic, rarely pigmented, multicellular and appendaged (Peláez et al. 2011, Jaklitsch et al. 2016).

Notes - This is one of the largest family of Leotiomycetes and phylogenetically highly controversial. Considering phylogenetic relationships according to the present study, the genera Endoscypha, Torrendiella, Roesleria, Lanzia, Glarea, Crocicreas, Ombrophila, Amylocarpus and Pirottaea which were phylogenetically unstable, clustered within Helotiaceae. Previous literature also showed the genetic relatedness of these genera within Helotiaceae, i.e. the hyphomycete genus Glarea clustered within Helotiaceae in the phylogeny of Peláez et al. (2011) and Johnston et al. 
(2014) showed the phylogenetic placement of the genera Cyathicula, Torrendiella, Roesleria, Glarea within Helotiaceae.

Therefore, considering the result of our phylogenetic analysis and previous literature, in this treatment we placed these genera (Endoscypha, Torrendiella, Roesleria, Lanzia, Glarea, Crocicreas, Ombrophila, Amylocarpus, Pirottaea) within Helotiaceae. Moreover the family Roesleriaceae nested within Helotiaceae. Therefore, we synonymized the family Roesleriaceae under Helotiaceae.

\section{Crocicreas sp1}

Fig. 27

Saprobic on dead stems. Sexual morph: Apothecia 150-200 $\times 300-400 \mu \mathrm{m}$, arising singly, stipitate. Receptacle cupulate, brown, smooth. Disc concave, brown. Ectal excipulum 15-20 $\mu \mathrm{m}(\bar{x}$ $=18.3 \mu \mathrm{m}, \mathrm{n}=10$ ) in lower flanks, composed of, thin-walled, light brown to hyaline cells of textura prismatica. Medullary excipulum $30-38 \mu \mathrm{m}(\bar{x}=30 \mu \mathrm{m}, \mathrm{n}=10)$ in lower flanks, composed of, thin-walled, hyaline cells of textura prismatica. Hymenium hyaline. Paraphyses $1.2-1.7 \mu \mathrm{m}$ wide $(\bar{x}=1.5 \mu \mathrm{m}, \mathrm{n}=20)$, numerous, filiform, obtuse, septate, smooth. Asci 55-75 $\times 4-6 \mu \mathrm{m}(\bar{x}=$ $68 \times 5.2 \mu \mathrm{m}, \mathrm{n}=30) 8$-spored, unitunicate, cylindric-clavate, rounded apex, amyloid, stipitate base, croziers absent. Ascospores 2.5-3.5 $\times 1.8-2.3 \mu \mathrm{m}(\bar{x}=2.9 \times 2.1 \mu \mathrm{m}, \mathrm{n}=40), 1-2$-seriate, ellipsoid, aseptate, hyaline, aguttulate. Asexual morph: Undetermined.

Material examined - UK, Hampshire, Hedge End, on herbaceous stem, 3 March 2016, E.B.G. Jones, GJ232 (MFLU 18-1822).

GenBank accessions - LSU- MK591963, ITS- MK584944, SSU- MK585024

Notes - Our collection of Crocicreas sp. from UK grouped with Crocicreas tomentosum from Spain (Fig. 26). The ITS data of our collection is similar to that of Crocicreas coronatum (CBS 197.62) (486/555-88\% with 9 gaps), Cudoniella clavus (ILLS:60488) (488/558-87\% with 12 gaps), Bisporella subpallida (G.M. 2016-02-14) (488/561-87\% with 13 gaps) and to Hymenoscyphus scutula (SAT132450) (484/557-87\% with 10 gaps).

This new collection of Crocicreas sp. is different from Crocicreas tomentosum by having smooth receptacle and globose ascospores (Dennis 1975). However, our collection had few apothecia and seems young. Moreover, we did not observe free ascospores. Therefore, we keep our collection under the genus Crocicreas until we have more data to stabilize its taxonomic placement.

\section{Crocicreas cf. tomentosum (Dennis) S.E. Carp.}

$=$ Cyathicula tomentosa Dennis

Facesoffungi number: FoF 05897; Fig. 28.

Saprobic on dead stems. Sexual morph: Apothecia 250-350 $\times 300-400 \mu \mathrm{m}$, arising singly, stipitate. Receptacle globlet to cupulate, tomentose. Disc concave. Hairs short-cylindric, septate, walls rough and granulate, brownish. Ectal excipulum 8-12 $\mu \mathrm{m}(\bar{x}=10.3 \mu \mathrm{m}, \mathrm{n}=10)$ in upper flanks, composed of thin-walled, light brown to hyaline, cells of textura oblita to prismatica. Medullary excipulum $25-32 \mu \mathrm{m}(\bar{x}=30 \mu \mathrm{m}, \mathrm{n}=10)$ in upper flanks, composed of thin-walled, hyaline cells of textura oblita to porrecta, ectal excipular cells are wider than medullary excipular cells. Hymenium hyaline. Paraphyses $2-2.5 \mu \mathrm{m}$ wide $(\bar{x}=2.1 \mu \mathrm{m}, \mathrm{n}=20)$, numerous, filiform, obtuse and slightly swollen towards the apex, aseptate or rarely septate, exceeding the asci in length, smooth, guttulate. Asci 50-65 $\times 5.5-7 \mu \mathrm{m}(\bar{x}=55.6 \times 5.8 \mu \mathrm{m}, \mathrm{n}=30)$ arising from croziers, 8-spored, unitunicate, cylindrical, conical to obtuse and amyloid apex, stipitate base, arising from croziers. Ascospores 9-12 $\times 2-3.5 \mu \mathrm{m}(\bar{x}=10.8 \times 3.2 \mu \mathrm{m}, \mathrm{n}=40), 1$-2-seriate, ellipsoid to fusoid, aseptate, hyaline, guttules are present at both ends. Asexual morph: Undetermined.

Material examined - Uzbekistan, Tashkent, Bostanliq, Oqtoshsoy, Ugam Range, Western Tien Shan Mountains, on Phlomoides sp., 10 April 2016, Yusufjon Gafforov, UZ1 (MFLU 170082).

GenBank accessions - LSU- MK592008, ITS- MK584988, SSU- MK585062 


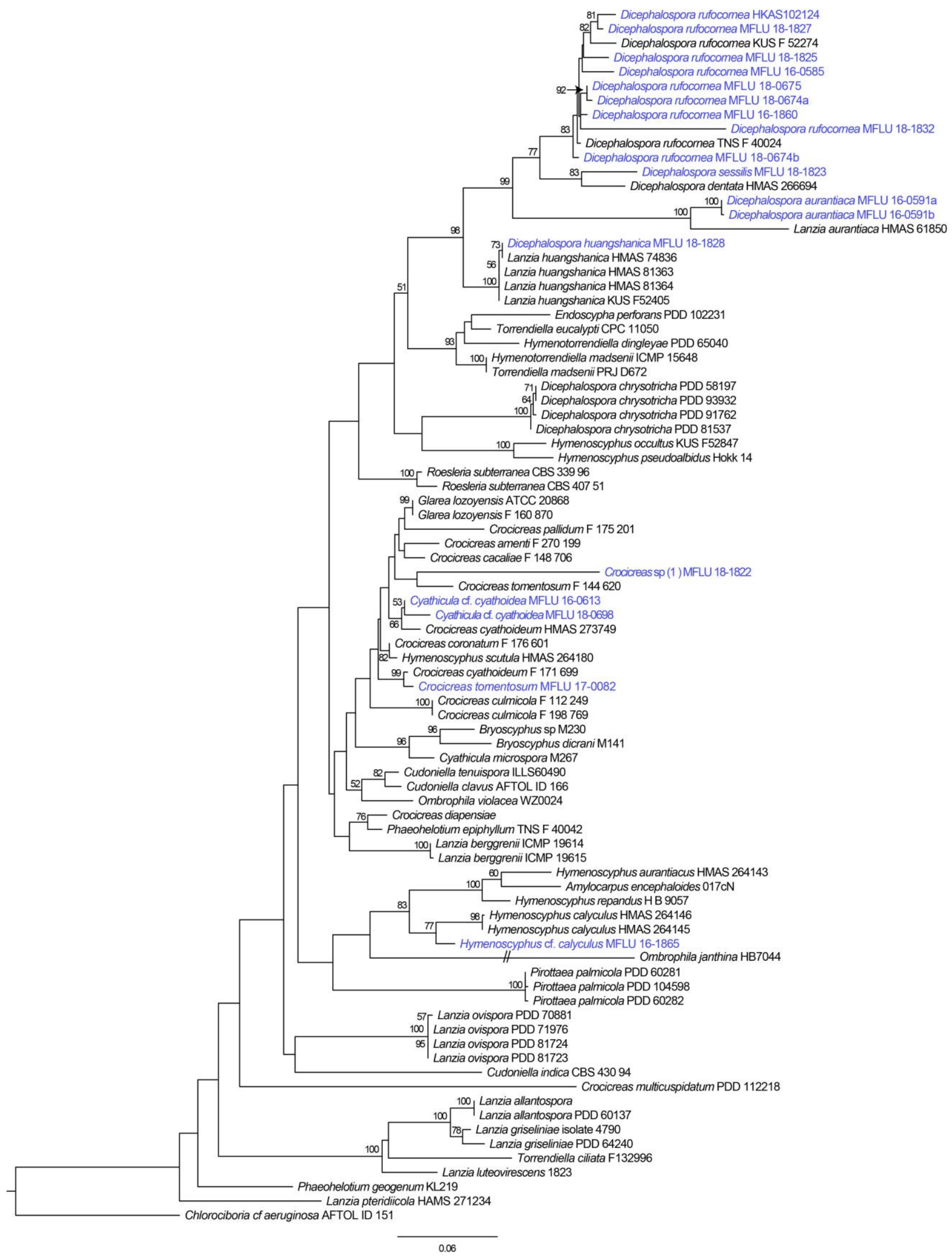

Figure 26 - Phylogram generated from maximum likelihood analysis of sequences of Helotiaceae based on ITS and LSU sequence data. MLBP values $\geq 50 \%$ are given near the nodes. Strain/culture numbers are given after the taxa. The tree is rooted with Chlorociboria cf. aeruginosa (AFTOL-ID 151). 


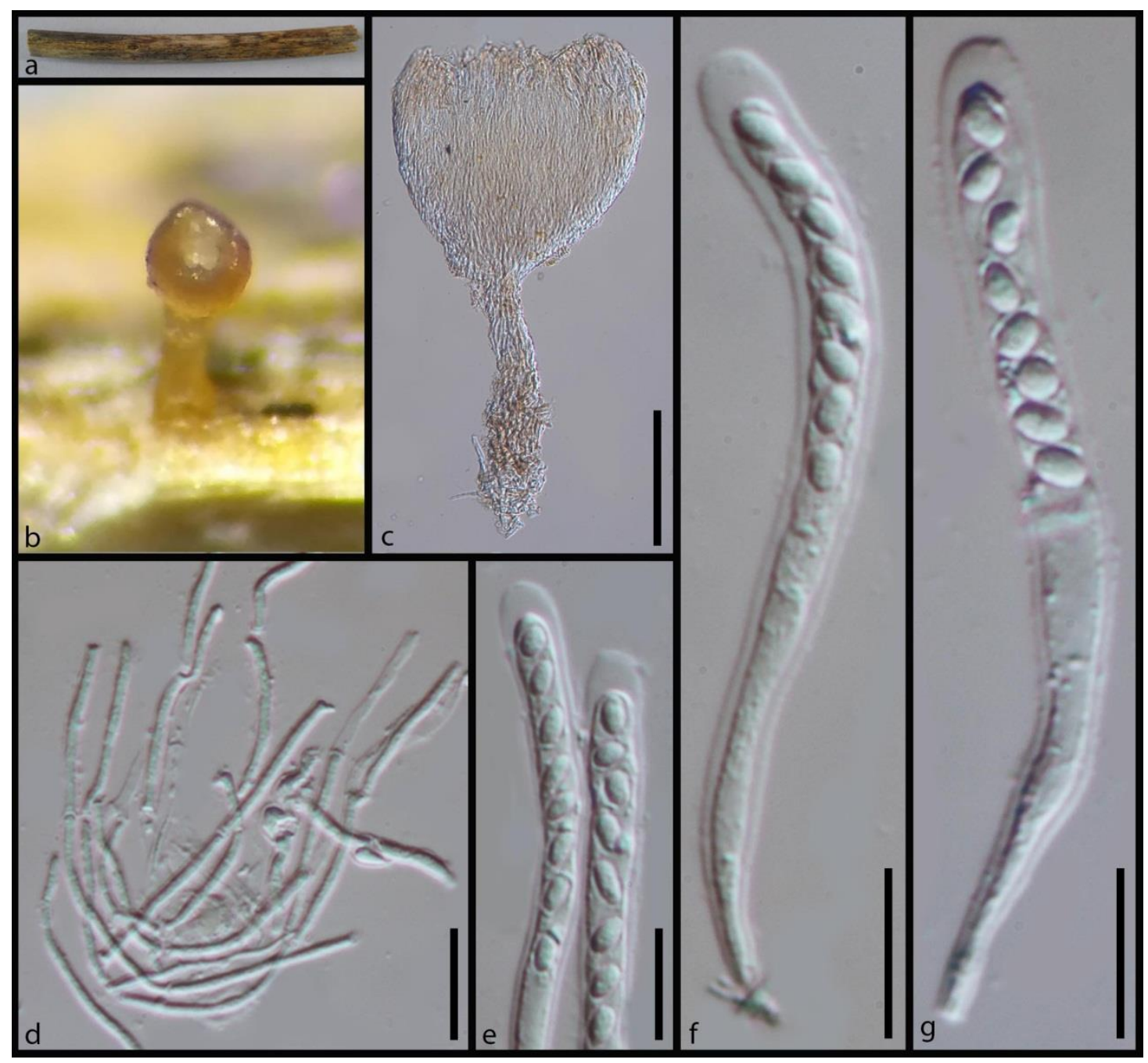

Figure 27 - Morphology of Crocicreas sp1 (MFLU 18-1822) a Substrate. b Apothecium on wood. c Cross section of an apothecium. d Cylindrical paraphyses. e Asci apices with ascospores. f, g Cylindric-clavate asci. Scale bars: $\mathrm{c}=100 \mu \mathrm{m}, \mathrm{d}-\mathrm{g}=10 \mu \mathrm{m}$.

Notes - Our new collection grouped with Cyathicula cyathoidea (F-171, 699) with strong statistical support (99\%) (Fig. 26). The ITS data of our collection is similar to that of C. cyathoidea (F-171,690) (461/461-100\%), C. cyathoidea (F-171,699) (459/461-99\% with no gaps). The LSU data of our isolate shows similarity to that of Hymenoscyphus scutula (isolate 5302) (823/835-99\% with no gaps) and Crocicreas coronatum (CBS 197.62) (800/812-99\% with no gaps), Cudoniella clavus (AFTOL-ID 166) (816/835-98\% with no gaps) and Cudoniella tenuispora (ILLS60490) (815/835-98\% with no gaps).

Our collection of Cyathicula from Uzbekistan is genetically the same as Cyathicula cyathoidea (F-171, 690) from Europe (Peláez et al. 2011), but it differs from the Chinese collection (HMAS:273749) (Zheng \& Zhuang 2015) (Fig. 26). Morphology of our collection is similar to the description from Quijada et al. (2017) although our collection has smaller asci and ascospores. Cyathicula cyathoidea is the most commonly collected and widely distributed species of the genus (Carpenter 1981) and the fungus was first reported from China by Tai (1979) as Phialea cyathoidea. Therefore, we suggest that Cyathicula cyathoidea $(\mathrm{F}-171,690)$ collection from Europe (Peláez et al. 2011) may require re-examination to confirm its identification.

Morphology of our collection is similar to the type description of Crocicreas tomentosum (Dennis 1975) except it has slightly smaller asci (Crocicreas tomentosum asci 60-80 $\times 5-7 \mu \mathrm{m}$ ). Considering these facts, we name our collection as Cyathicula cf. tomentosum. 


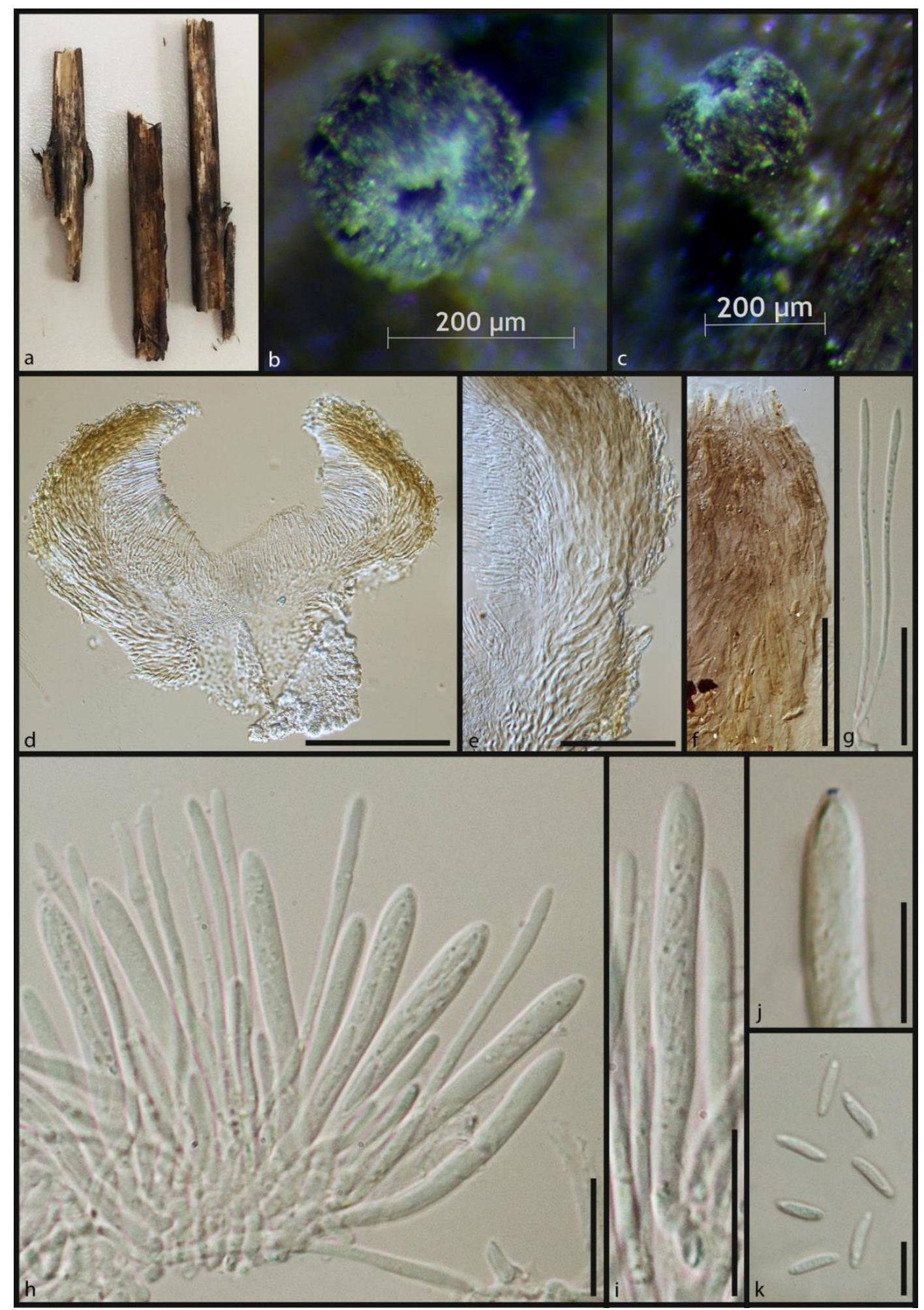

Figure 28 - Morphology of Crocicreas cf. tomentosum (MFLU 17-0082) a Substrate. b Apothecia on wood. c Apothecium on wood. d Cross section of an apothecium. e Close up of the cross section of apothecium at margins. f Brown pigmented hairs. g Aseptate paraphyses. h Asci and paraphyses. $\mathrm{i}$ Cylindrical asci. $\mathrm{j}$ Apex of the asci with the plug blueing in Melzer's reagent. $k$ Fusoid ascospores. Scale bars: $\mathrm{d}=100 \mu \mathrm{m}, \mathrm{e}=30 \mu \mathrm{m}, \mathrm{f}=50 \mu \mathrm{m}, \mathrm{g}-\mathrm{i}=20 \mu \mathrm{m}, \mathrm{j}-\mathrm{k}=10 \mu \mathrm{m}$.

Cyathicula cyathoidea (Bull.) Thüm.

$=$ Crocicreas cyanthoideum

Facesoffungi number: FoF 05898; Fig. 29 
Saprobic on dead stems. Sexual morph: Apothecia 300-700 $\times 160-200 \mu \mathrm{m}$, arising singly, stipitate. Receptacle globlet to cupulate, brownish with glassy appearance. Disc concave. Ectal excipulum 30-35 $\mu \mathrm{m}(\bar{x}=33.8 \mu \mathrm{m}, \mathrm{n}=10)$ in lower flanks, composed of thin-walled, light brown to hyaline cells of textura prismatica. Medullary excipulum $45-55 \mu \mathrm{m}(\bar{x}=47 \mu \mathrm{m}, \mathrm{n}=10)$ in lower flanks, composed of thin-walled, hyaline cells of textura intricata. Hymenium hyaline. Paraphyses $1.5-2 \mu \mathrm{m}$ wide $(\bar{x}=1.8 \mu \mathrm{m}, \mathrm{n}=20)$, numerous, filiform, obtuse, aseptate or rarely septate, smooth, guttulate. Asci 35-45 $\times 4-5.5 \mu \mathrm{m}(\bar{x}=38.3 \times 4.5 \mu \mathrm{m}, \mathrm{n}=30)$, arising from simple septa, 8-spored, unitunicate, cylindrical, conical to rounded apex, amyloid, short-stipitate base, arising from croziers. Ascospores not observed. Asexual morph: Undetermined.

Material examined - Russia, Arkhangelsk region, Akhangelsk City, Maimaksansky City District, ruderalized floodplain meadow, saprobic on dead stems of Cirsium arvense (L.) Scop. (= Cirsium setosum (Willd.) Besser, Asteraceae), 22 May 2015, Gennady V. Okatov, T582 (MFLU 16-0613); Singleton, West Sussex, 5 April 2017, E.B.G. Jones, GJ349 (MFLU 18-0698).

GenBank accessions - MFLU 18-0698: LSU- MK591970, ITS- MK584943, SSUMK585031, TEF- MK637047, RPB2- MK388217; MFLU 16-0613: LSU- MK591957, ITSMK584998, SSU- MK585012, TEF- MK637041

Notes - Our collections of Cyathicula cf. cyathoidea from UK and Russia clustered with the Chinese collection of $C$. cyathoidea (HMAS 273749) (Zheng \& Zhuang 2015) (Fig. 26). The clade of these three isolates is supported by $66 \%$ of statistical support.

The ITS region of Russian collection is similar to that of Cyathicula cyathoidea (HMAS:273737) (505/512-99\% with no gaps), Crocicreas coronatum (CBS 197.62) (537/549-98\% with 1 gap) and Crocicreas coronatum (HMAS:273735) (503/514-98\% with 3 gaps). The ITS data of UK collection differs from the Russian collection by three base pairs. The LSU data of our Russian collection is similar to that of Hymenoscyphus scutula (isolate 5302) (879/885-99\% with 2 gaps), Crocicreas coronatum (CBS 197.62) (876/882-99\% with 2 gaps) and Cudoniella clavus (AFTOL-ID 166) (874/885-99\% with 2 gaps). The LSU data of UK collection has five base pair differences from that of Russian collection.

Morphology of our collection is similar to the description provided by Quijada et al. (2017) although it has smaller asci. According to the key provided by Zheng \& Zhuang (2015), our species is similar to Cyathicula cyathoideum from apothecial shape, size, and colour and asci amyloidity and size. However, we did not observe ascospores in any of our collections. Considering these facts, we name our collection as Crocicreas cyanthoideum.

Dicephalospora sessilis Ekanayaka \& K.D. Hyde, sp. nov.

Index Fungorum number: IF556289; Facesoffungi number: FoF 05899; Fig. 30.

Etymology - refers to sessile apothecia

Holotype - MFLU 18-1823

Saprobic on dead stems. Sexual morph: Apothecia $0.8-1 \times 0.6-1 \mathrm{~mm}$, arising singly, sessile, slightly erumpent. Receptacle cupulate, reddish orange. Margins smooth, magenta to reddish orange. Disc concave, magenta to orange. Ectal excipulum $40-50 \mu \mathrm{m}(\bar{x}=44 \mu \mathrm{m}, \mathrm{n}=10)$ in upper flanks, composed of thin-walled, yellowish to hyaline cells of textura prismatica to intricata. Medullary excipulum $90-115 \mu \mathrm{m}(\bar{x}=102 \mu \mathrm{m}, \mathrm{n}=10)$ in upper flanks, composed of thin-walled, yellowish to hyaline, gelatinized cells of textura intricata. Hymenium hyaline to yellowish. Paraphyses $1.5-3 \mu \mathrm{m}$ wide $(\bar{x}=1.8 \mu \mathrm{m}, \mathrm{n}=20)$, numerous, filiform, obtuse, aseptate, exceeding the asci in length, smooth. Asci $130-140 \times 15-20 \mu \mathrm{m}(\bar{x}=134.4 \times 16.3 \mu \mathrm{m}, \mathrm{n}=30) 8$-spored, unitunicate, cylindric-clavate, rounded apex, stipitate base, croziers absent. Ascospores $15-20 \times 5-$ $10 \mu \mathrm{m}(\bar{x}=18.2 \times 7 \mu \mathrm{m}, \mathrm{n}=40), 1-2$-seriate, ellipsoid to fusoid, pointed ends, sometimes with gelatinous cap, aseptate, hyaline to yellowish, guttulate. Asexual morph: Undetermined.

Material examined - China, Yunnan Province, Kunming, Kunming institute of botany, Botanical Garden, 24 May 2018, A.H. Ekanayaka, HC19 (MFLU 18-1823).

GenBank accessions - LSU- MK591974, ITS- MK584947, SSU- MK585047, TEFMK714028, RPB2- MK577779 


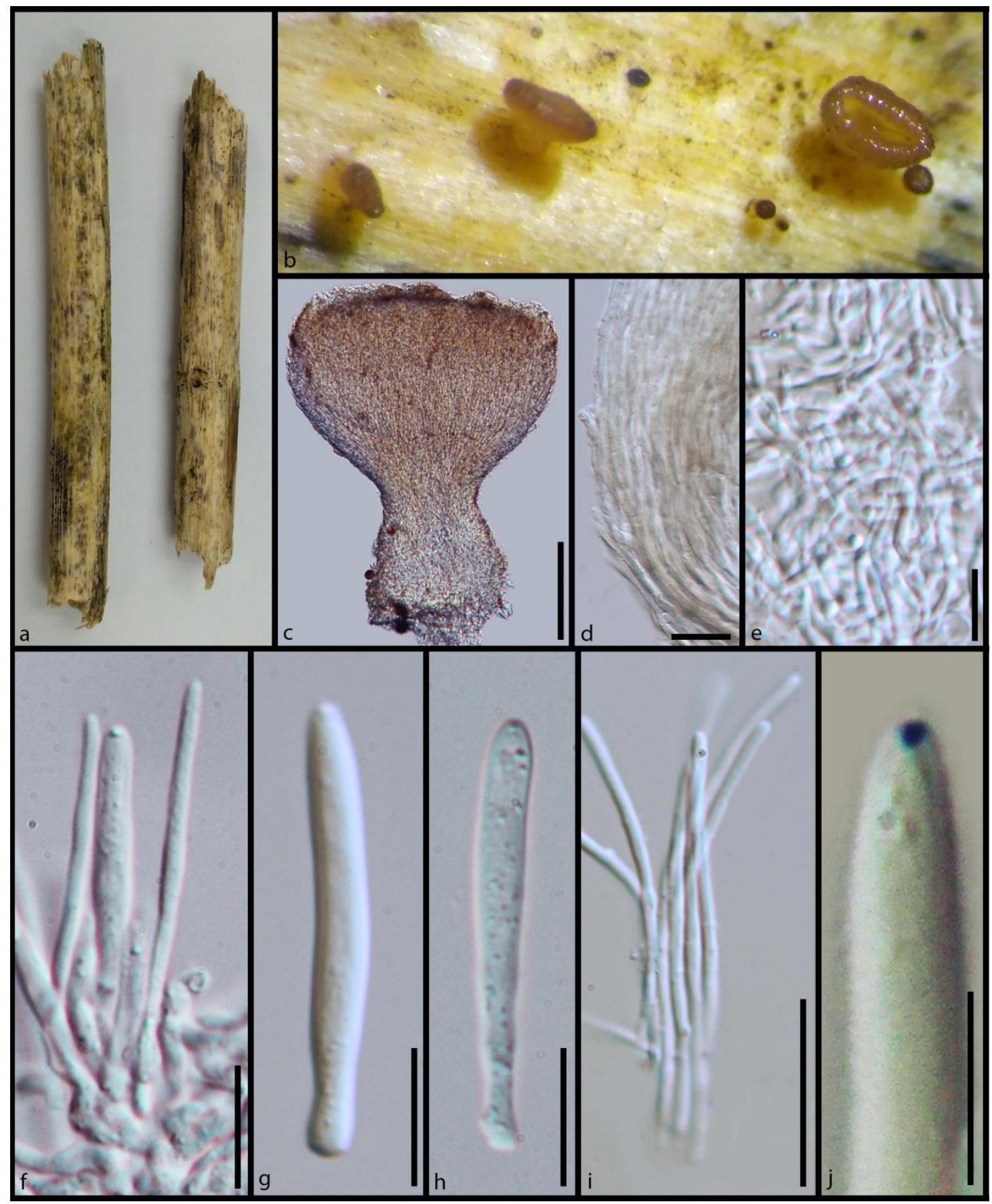

Figure 29 - Morphology of Cyathicula cyathoidea (MFLU 18-0698) a Substrate, b Rehydrated apothecia on wood, c Cross section of an apothecium, d Ectal excipular cells, e Medullary excipular cells, f Asci and paraphyses, g, h Cylindric-clavate asci, i Filiform paraphyses, $\mathrm{j}$ Amyloid ascus apex in Melzer's reagent. Scale bars: $c=200 \mu \mathrm{m}, \mathrm{d}, \mathrm{i}=20 \mu \mathrm{m}, \mathrm{e}-\mathrm{h}=10 \mu \mathrm{m}, \mathrm{j}=5 \mu \mathrm{m}$.

Notes - Our Chinese collection HC19 grouped sister to Dicephalospora dentata HMAS 266694 with strong statistical support of $83 \%$ (Fig. 26). The ITS data of our species is similar to that of Dicephalospora rufocornea (TNS:F-40024) (517/554-93\% with 17 gaps). LSU data of our collection shows 97\% similarity to that of Dicephalospora rufocornea (TNS:F-40024) (1060/109797\% with 8 gaps).

Dicephalospora sessilis is characterized by having sessile, cupulate, reddish orange apothecia, smooth margins, gelatinous excipulum, filiform paraphyses, cylindric-clavate asci and ellipsoid to fusoid ascospores with pointed ends. Our new species is phylogenetically close to Dicephalospora dentata and D. rufocornea. However, D. dentata differs from $D$. sessilis by having 
dentate apothecial margins, longer asci and narrower ascospores and D. rufocornea differs in having stipitate apothecia (Spooner 1987, Liu et al. 2016). Dicephalospora sessilis is similar to D. calochroa, but differs in having smaller asci and ascospores (Spooner 1987).

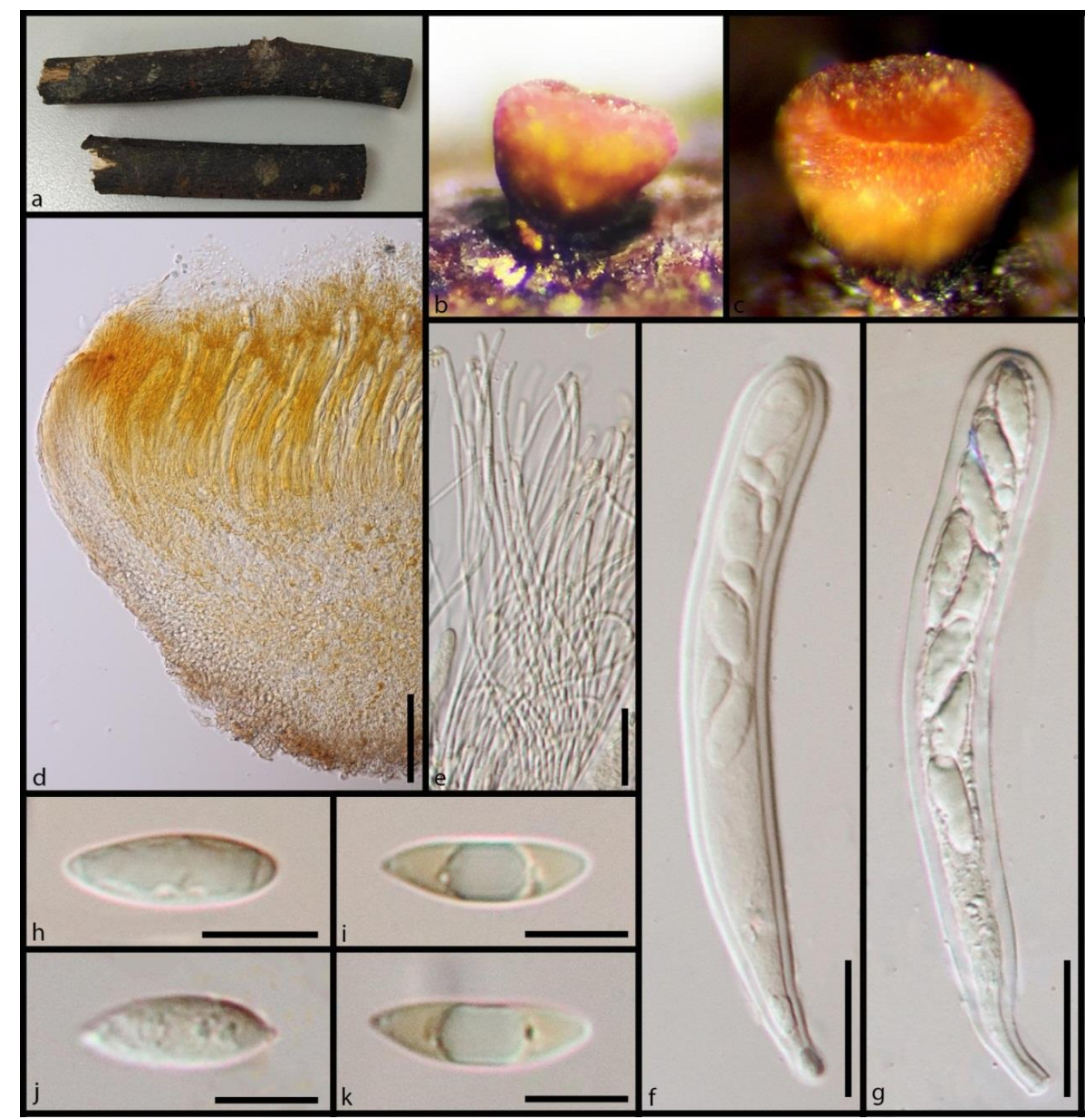

Figure 30 - Morphology of Dicephalospora sessilis (MFLU 18-1823 holotype) a Substrate. b, c Apothecia on wood. d Cross section of an apothecium at margins. e Filiform paraphyses. $\mathrm{f}-\mathrm{g}$ Cylindric-clavate asci. $\mathrm{h}-\mathrm{k}$ Fusoid ascospores. Scale bars: $\mathrm{d}=60 \mu \mathrm{m}, \mathrm{f}, \mathrm{g}=25 \mu \mathrm{m}, \mathrm{h}-\mathrm{k}=10 \mu \mathrm{m}$, e $=20 \mu \mathrm{m}$.

\section{Dicephalospora rufocornea (Berk. \& Broome) Spooner}

Facesoffungi number: FoF 05900; Fig. 31

Saprobic on dead stems. Sexual morph: Apothecia $2-2.5 \times 1.2-1.6 \mathrm{~mm}(\bar{x}=2.30 \times 1.43$ $\mathrm{mm}, \mathrm{n}=10$ ) arising singly or in small groups, superficial, stipitate, red or reddish orange when fresh. Receptacle cupulate, disc concave and red, margins red or orange, smooth. Stipe red, central, medium to long in length. Ectal excipulum $27-32 \mu \mathrm{m}(\bar{x}=29.7 \mu \mathrm{m}, \mathrm{n}=10)$ wide at margins and flanks, composed of yellow colour cells in margins and hyaline cells in flanks of textura prismatica, marginal cells are elongated, arranged in rows, end with a swollen tip and secrete yellow colour pigment which can dissolve in KOH. Medullary excipulum 90-110 $\mu \mathrm{m}(\bar{x}=97 \mu \mathrm{m}$, $\mathrm{n}=10$ ) comprising hyaline cells of textura epidomoidea. Hymenium yellow. Paraphyses $0.9-2.1$ $\mu \mathrm{m}$ wide $(\bar{x}=1.5 \mu \mathrm{m}, \mathrm{n}=20)$, numerous, filiform, septate. Asci 130-145 $\times 9-12 \mu \mathrm{m}(\bar{x}=140 \times$ $10.9 \mu \mathrm{m}, \mathrm{n}=30$ ), 8-spored, unitunicate, cylindrical, apex obtusely conical, inoperculate, faintly 
amyloid, sessile base, croziers absent. Ascospores $25-40 \times 3.1-5.2 \mu \mathrm{m}(\bar{x}=31.8 \times 4 \mu \mathrm{m}, \mathrm{n}=40)$, 1-2-seriate, hyaline, smooth, aseptate, but containing row of large guttules, fusiform, often slightly curved, pointed tips capped with a small, obconical gelatinous collar. Asexual morph: Undetermined.

Material examined - Thailand, Chiang Rai Province, Doi Mae Salong, on dead stems, 22 June 2015, A.H. Ekanayaka, HD023 (MFLU 16-0585); Same collection details HD30Y (MFLU 18-0675), HD30b (MFLU 18-0674a), HD30M (MFLU 18-0674b); China, Yunnan Province, Kunming, December 2015, S.C. Karunarathna, NB205 (MFLU 16-1860); China, Honghe, Yunnan Province, 15 June 2018, Junfu Li, HC40 (MFLU 18-1827, HKAS102128); China, Jinghong, Xishuangbanna, Yunnan Province, 9 June 2018, Zeng Ming, HC38 (MFLU 18-1825, HKAS102126), HC36 (MFLU 18-1832, HKAS102124).

GenBank accessions - MFLU 16-0585: LSU- MK591984, ITS- MK584955, TEFMK714021, RPB2- MK388222; MFLU 18-0675: LSU- MK591987, ITS- MK584961, TEFMK714022, RPB2- MK614723; MFLU 18-0674a: ITS- MK584959, TEF- MK714023; MFLU 180674b: LSU- MK591989, ITS- MK584960, SSU- MK585039, TEF- MK689342; MFLU 16-1860: LSU- MK592011, ITS- MK584989, SSU- MK585064; MFLU 18-1827: LSU- MK591978, ITSMK584978, SSU- MK585050, TEF- MK714031, RPB2- MK577781; MFLU 18-1825: LSUMK591976, ITS- MK584949, SSU- MK585048, TEF- MK714030, RPB2- MK614729; MFLU 181832: ITS- MK584977, TEF- MK714029

Notes - Eight of our collections from China and Thailand clustered with Dicephalospora rufocornea complex (Fig. 26). The clade received high statistical support of 83\%. Both ITS and LSU data of our collections are 99-98\% similar to those of Dicephalospora rufocornea (TNS:F40024, KUS-F52274 and HMAS 75518).

Dicephalospora rufocornea is characterized by yellowish to reddish orange apothecia, excipulum pigmented and pigments dissolved in $\mathrm{KOH}$, cylindrical amyloid asci and fusoid ascospores with pointed tips capped with a small, obconical gelatinous collar. Our collections are similar to the description from Spooner (1987).

We observed slightly different morphologies among our collections, such as apothecial colour yellowish orange to bright red, Asci length varied from 70-140 $\mu \mathrm{m}$, and ascospore length from $20-45 \mu \mathrm{m}$. More genetic markers with detailed morphological analyses are required to resolve this species complex.

Dicephalospora huangshanica (W.Y. Zhuan) W.Y. Zhuang \& Z.Q. Zeng

= Lanzia huangshanica $\mathrm{W}$.Y. Zhuang

Facesoffungi number: FoF 05901; Fig. 32

Saprobic on dead stems. Sexual morph: Apothecia $0.5-0.8 \times 0.8-1.3 \mathrm{~mm}$, arising singly, stipitate. Receptacle cupulate, yellowish to cream. Disc concave, magenta or dark red. Margins concolorous to disc. Ectal excipulum 25-35 $\mu \mathrm{m}(\bar{x}=27.4 \mu \mathrm{m}, \mathrm{n}=10)$ in lower flanks, composed of thin-walled, yellowish cells of textura prismatica with globose tips. Medullary excipulum 70-90 $\mu \mathrm{m}(\bar{x}=80 \mu \mathrm{m}, \mathrm{n}=10)$ in lower flanks, composed of thin-walled, yellow cells of textura prismatica. Hymenium hyaline. Paraphyses $1.8-3 \mu \mathrm{m}$ wide $(\bar{x}=2.5 \mu \mathrm{m}, \mathrm{n}=20)$, numerous, filiform, obtuse and slightly swollen at the apex, aseptate, exceeding the asci in length, smooth. Asci $105-120 \times 10-15 \mu \mathrm{m}(\bar{x}=108 \times 13 \mu \mathrm{m}, \mathrm{n}=30) 8$-spored, unitunicate, cylindric-clavate, rounded apex, amyloid, sub-stipitate base, croziers absent. Ascospores $20-25 \times 4.5-5 \mu \mathrm{m}(\bar{x}=23.7$ $\times 4.6 \mu \mathrm{m}, \mathrm{n}=40$ ), multi-seriate, fusoid, aseptate, hyaline to yellowish, guttulate. Asexual morph: Undetermined.

Material examined - China, Yunnan Province, Honghe, 15 June 2018, Junfu Li, HC41 (MFLU 18-1828, HKAS102129).

GenBank accessions - LSU- MK591979, ITS- MK584979, SSU- MK585051, TEFMK714032, RPB2- MK577782

Notes - Our new collection from China grouped with Lanzia huangshanica collections from China (HMAS 74836, HMAS 81363, HMAS 81364) and Korea (KUS F52405) (Fig. 26). The $L$. 
huangshanica clade received strong statistical support of $100 \%$. The ITS data of our collection is identical to that of L. huangshanica (HMAS 74836) and 99\% to L. huangshanica (KUS-F52405) (475/477-99\% with 1 gap). The LSU data is similar to L. huangshanica (KUS-F52405) (782/78399\% with no gaps).

Dicephalospora huangshanica is characterized by cupulate stipitate apothecia with yellowish to cream receptacle and magenta disc, filiform paraphyses slightly swollen at the apex, cylindricclavate asci and fusoid ascospores (Zhuang 1995). Our new collection of D. huangshanica, collected from its type locality, phylogenetically confirmed its identification (Fig. 26). Morphological characters of our collection are in agreement with the description by (Zhuang 1995).

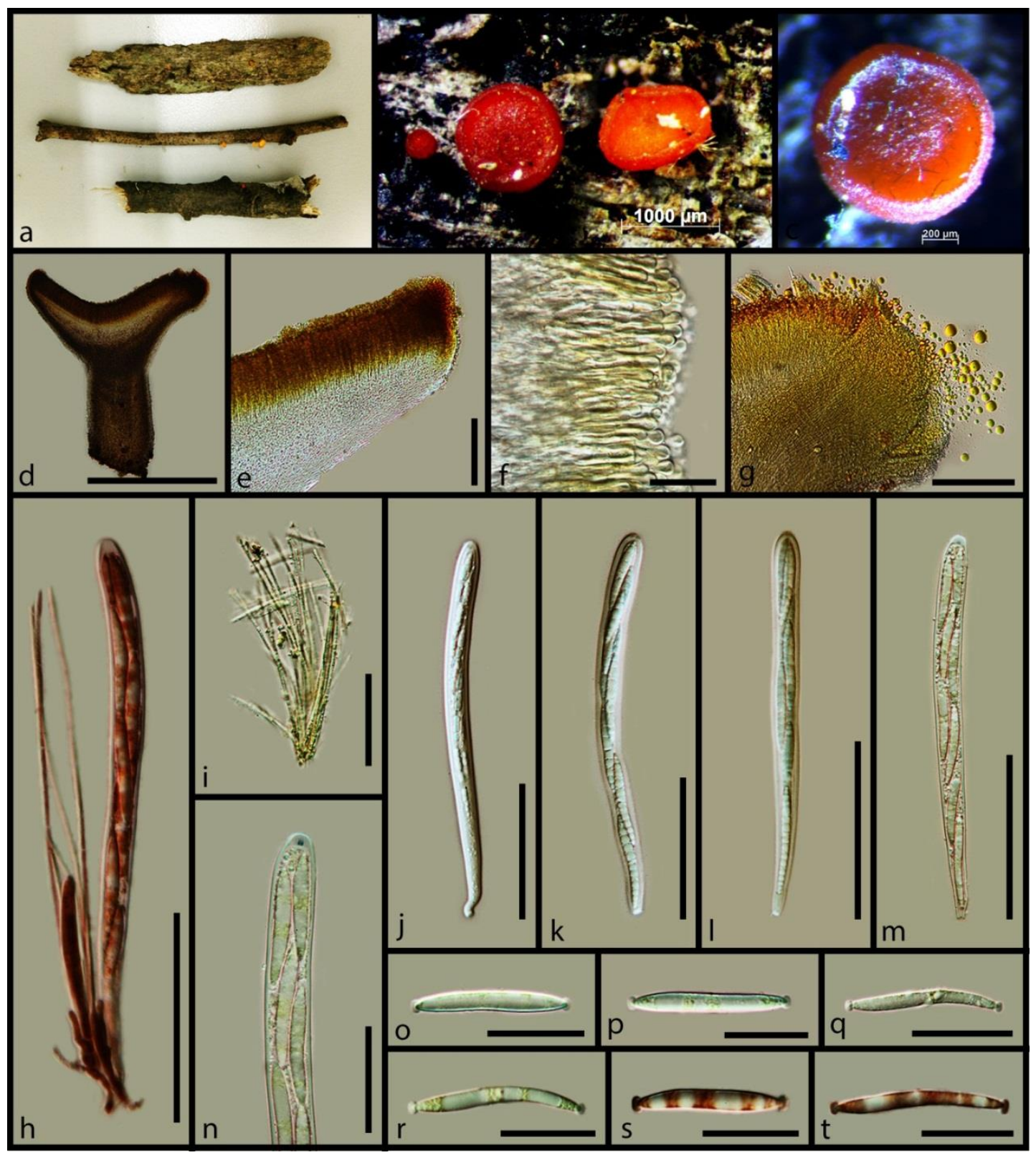

Figure 31 - Morphology of Dicephalospora rufocornea (MFLU 16-0585) a Substrate. b Apothecia on wood. c Apothecium on wood. d Cross section of an apothecium. e Close up of the cross section of apothecium at margins. f Marginal cells with swollen tips. g Pigments of marginal cells dissolving in $\mathrm{KOH} . \mathrm{h}$ Bunch of asci and paraphyses in congo red reagent (immature asci arising from crozier). i Filiform paraphyses. $\mathrm{j}-\mathrm{m}$ Cylindric-clavate asci ( $\mathrm{j}-1$ in distilled water and $\mathrm{m}$ in Melzer's reagent). $\mathrm{n}$ Apex of the asci with the plug blueing in Melzer's reagent. o- $t$ Fusiform ascospores. Scale bars: $\mathrm{b}-\mathrm{c}=200 \mu \mathrm{m}, \mathrm{d}=1000 \mu \mathrm{m}, \mathrm{e}=150 \mu \mathrm{m}, \mathrm{f}=100 \mu \mathrm{m}, \mathrm{g}=200 \mu \mathrm{m}, \mathrm{h}=60$ $\mu \mathrm{m}, \mathrm{i}=40 \mu \mathrm{m}, \mathrm{j}-\mathrm{m}=50 \mu \mathrm{m}, \mathrm{n}=50 \mu \mathrm{m}, \mathrm{o}-\mathrm{t}=20 \mu \mathrm{m}$. 


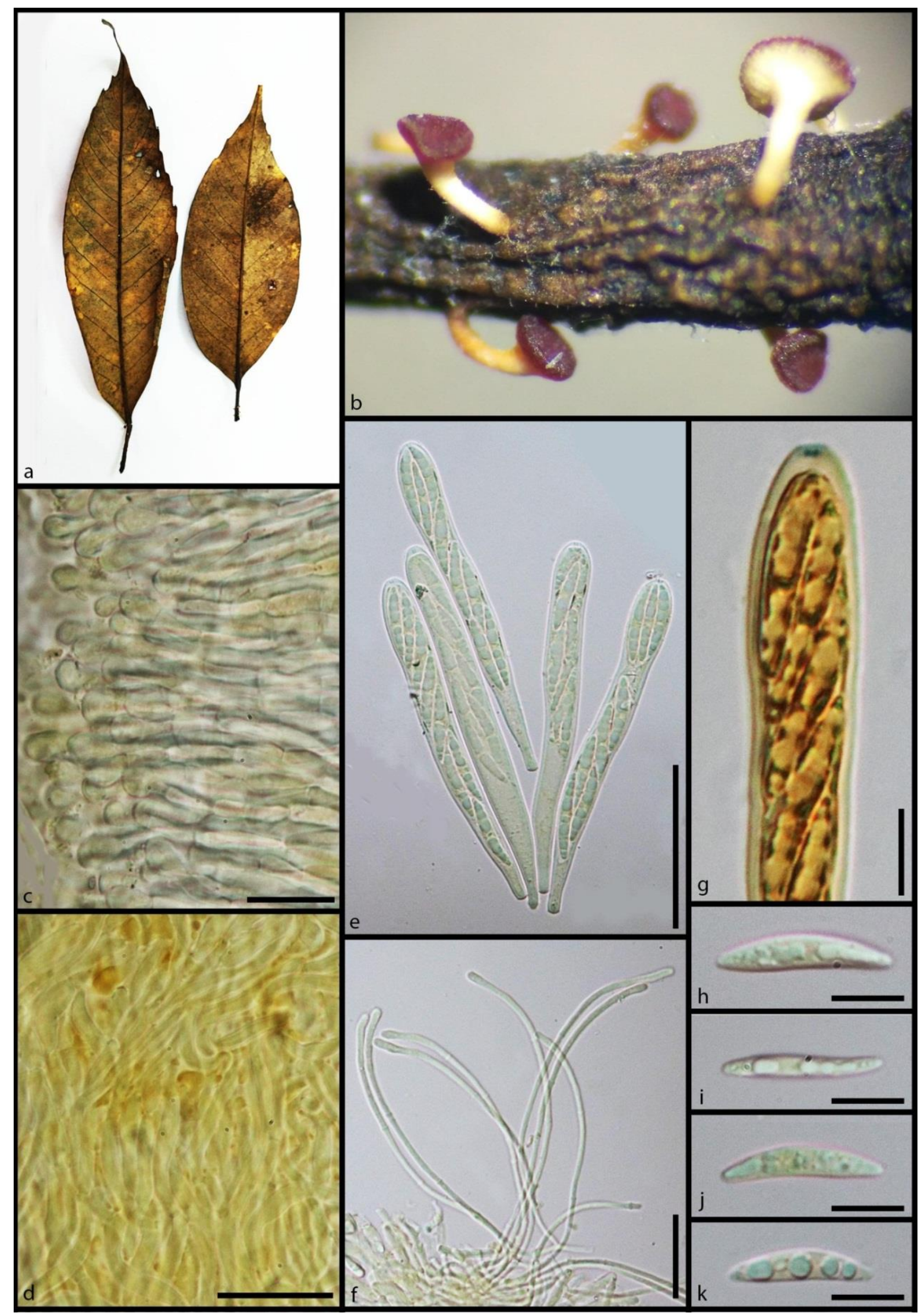

Figure 32 - Morphology of Dicephalospora huangshanica (MFLU 18-1828) a Substrate. b Apothecia on dead leaves. c Ectal excipular cells. d Medullary excipular cells. e Cylindric-clavate asci. f Filiform paraphyses. g Amyloid ascus apex. h-k Fusoid ascospores. Scale bars: c, d = 20 $\mu \mathrm{m}, \mathrm{e}=50 \mu \mathrm{m}, \mathrm{f}=10 \mu \mathrm{m}, \mathrm{h}-\mathrm{k}=10 \mu \mathrm{m}, \mathrm{g}=10 \mu \mathrm{m}$. 
Dicephalospora aurantiaca (W.Y. Zhuan) W.Y. Zhuang \& Z.Q. Zeng

Facesoffungi number: FoF 05902; Fig. 33

Saprobic on dead stems. Sexual morph: Apothecia $2-2.5 \times 1.2-1.6 \mathrm{~mm}(\bar{x}=2.30 \times 1.43$ $\mathrm{mm}, \mathrm{n}=10$ ), arising singly or in small groups, superficial, stipitate, yellow to orange when fresh. Receptacle cupulate, disc concave and yellow to orange, margins yellow to orange, smooth. Stipe light yellow, central, medium to long in length. Ectal excipulum $20-25 \mu \mathrm{m}(\bar{x}=22.9 \mu \mathrm{m}, \mathrm{n}=10)$ wide at lower flanks, composed of yellow cells of textura prismatica. Medullary excipulum 28-32 $\mu \mathrm{m}(\bar{x}=30 \mu \mathrm{m}, \mathrm{n}=10)$ wide at lower flanks, comprising hyaline cells of textura epidomoidea. Hymenium yellow. Paraphyses 2.6-1.8 $\mu \mathrm{m}$ wide $(\bar{x}=2.8 \mu \mathrm{m}, \mathrm{n}=20)$, numerous, filiform, septate, apices are slightly swollen, exceed the asci in length. Asci 90-120× 7.9-8.9 $\mu \mathrm{m}(\bar{x}=96.1 \times 8.4$ $\mu \mathrm{m}, \mathrm{n}=30$ ), 8-spored, unitunicate, cylindrical, apex obtusely conical, inoperculate, non-amyloid, short-stipitate, arising from croziers. Ascospores 23.3-27.2 $\times 3.1-4.2 \mu \mathrm{m}(\bar{x}=25.4 \times 3.6 \mu \mathrm{m}, \mathrm{n}=$ 40), uniseriate, hyaline, smooth, aseptate, but containing row of large guttules, fusiform, often slightly curved. Asexual morph: Undetermined.

Material examined - Thailand, Chiang Mai Province, Mushroom Research Center, on dead stems, 19 July 2015, A.H. Ekanayaka, HD030n, HD30a (MFLU 16-0591).

GenBank accessions - MFLU 16-0591b: ITS- MK584958, SSU- MK585038, TEFMK714024, RPB2- MK614722; MFLU 16-0591a: LSU- MK591988, ITS- MK584962

Notes - Our collections of HD030n and HD030a grouped with a Chinese collection of Dicephalospora aurantiaca (HMAS 61850) with strong statistical support of 100\% (Fig. 26). For D. aurantiaca, only ITS data available in GenBank and it is 94\% (307/326-94\% with 2 gaps) similar to ITS data of our collections. The LSU data of our species is $98 \%$ similar to that of $D$. rufocornea (TNS:F-40024) (930/949-98\% with 8 gaps).

Dicephalospora aurantiaca is characterized by having bright yellow apothecia, non-amyloid cylindric-clavate asci and aseptate, fusoid ascospores. Morphology of our collection is similar to the description of $D$. aurantiaca by Zhuang \& Liu (2007).

\section{Hymenoscyphus cf. calyculus (Fr.) W. Phillips}

Facesoffungi number: FoF 05903; Fig. 34

Saprobic on dead stems. Sexual morph: Apothecia 300-700 $\times 200-600 \mu \mathrm{m}$, arising singly, stipitate. Receptacle cupulate, yellowish brown when fresh and brown when dry. Disc concave. Ectal excipulum $25-35 \mu \mathrm{m}(\bar{x}=28.3 \mu \mathrm{m}, \mathrm{n}=10)$ in upper flanks, composed of thin-walled, light brown to hyaline cells of textura prismatica. Medullary excipulum 65-70 $\mu \mathrm{m}(\bar{x}=68 \mu \mathrm{m}, \mathrm{n}=10)$ in lower flanks, composed of thin-walled, hyaline cells of textura prismatica. Hymenium hyaline. Paraphyses $1-2 \mu \mathrm{m}$ wide $(\bar{x}=1.7 \mu \mathrm{m}, \mathrm{n}=20)$, numerous, filiform, obtuse, aseptate, smooth, aguttulate. Asci 80-95 $\times 5-7 \mu \mathrm{m}(\bar{x}=84 \times 5.7 \mu \mathrm{m}, \mathrm{n}=30)$, 8-spored, unitunicate, cylindricclavate, apex rounded to conical and amyloid, long-stipitate base, croziers absent. Ascospores $8.5-$ $10 \times 2.5-3.5 \mu \mathrm{m}(\bar{x}=8.9 \times 2.8 \mu \mathrm{m}, \mathrm{n}=40), 1-2$-seriate, fusoid to ellipsoid, aseptate, hyaline, guttulate. Asexual morph: Undetermined.

Material examined - Thailand, Chiang Mai Province, Mushroom Research Center, 18 July 2017, A.H. Ekanayaka, HD50 (MFLU 16-1865).

GenBank accessions - LSU- MK591991, ITS- MK584966

Notes - Our collection of Hymenoscyphus calyculus from Thailand grouped with the Chinese collection of Hymenoscyphus calyculus (Fig. 26). The ITS data of our specimen shows similarity to that of $H$. calyculus (isolate 5818) (460/484-95\% with 6 gaps) and to $H$. repandus (H.B. 9057) (465/518-90\% with 14 gaps). The LSU data is similar to that of $H$. calyculus (isolate 5818) (807/811(99\% with no gaps) and H. aurantiacus (HMAS 264143) (791/811-98\% with 3 gaps).

Our collection is similar to the description of $H$. calyculus by Phillips (1887) except it has smaller ascospores. Our collection has only a few apothecia and seems young; it did not show further growth in incubation. 


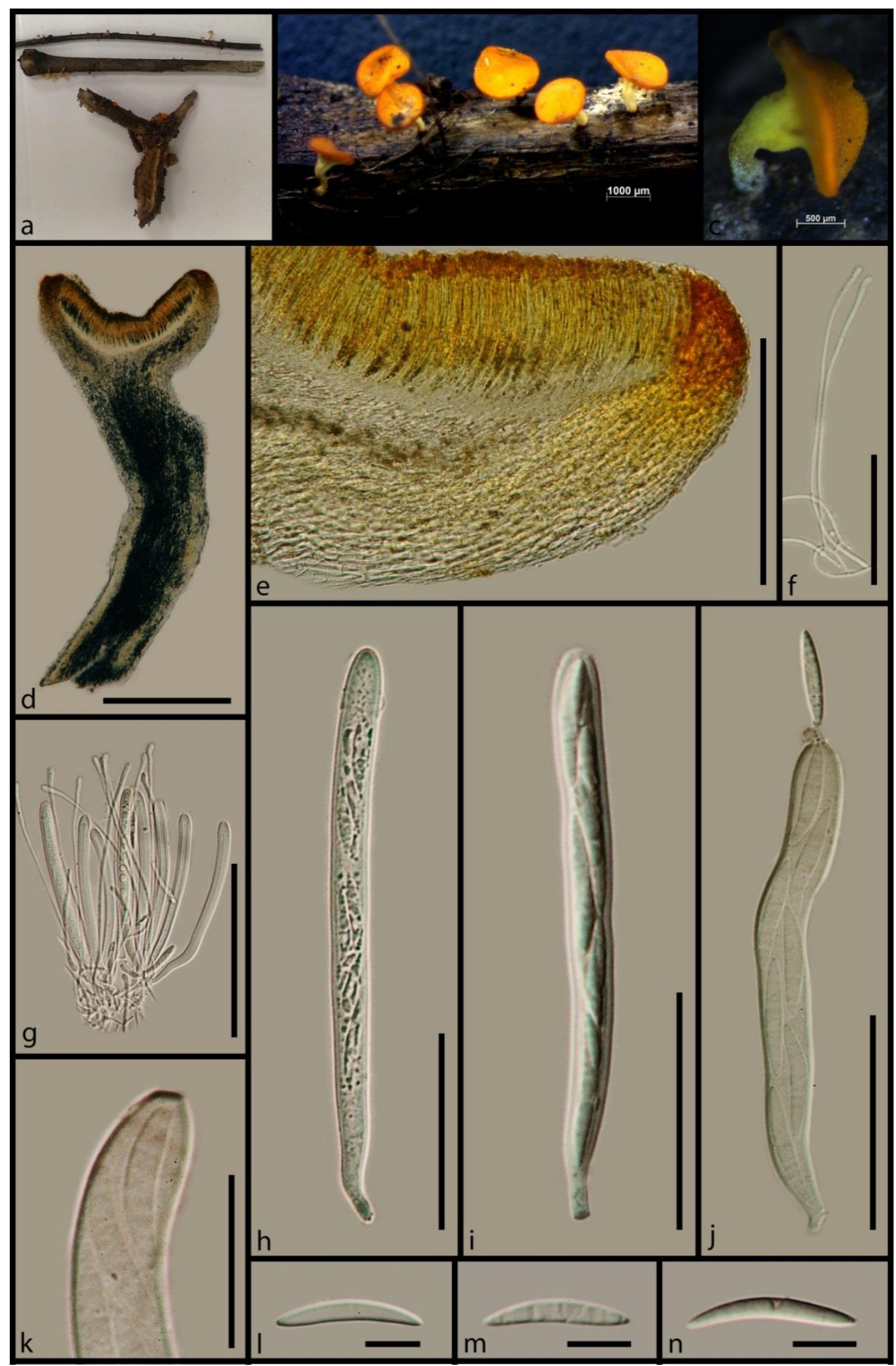

Figure 33 - Morphology of Dicephalospora aurantiaca (MFLU 16-0591) a Substrate. b Apothecia on wood. c Apothecium on wood. d Cross section of an apothecium. e Close up of the cross section of apothecium at margins. f Filiform paraphyses. $g$ Bunch of asci and paraphyses. $\mathrm{h}-\mathrm{j}$ Cylindricclavate asci. $k$ Apex of the asci. $1-n$ Fusiform ascospores. Scale bars: $b=200 \mu \mathrm{m}, \mathrm{c}=500 \mu \mathrm{m}, \mathrm{d}-\mathrm{e}$ $=200 \mu \mathrm{m}, \mathrm{f}=150 \mu \mathrm{m}, \mathrm{g}=100 \mu \mathrm{m}, \mathrm{h}-\mathrm{j}=40 \mu \mathrm{m}, \mathrm{k}=20 \mu \mathrm{m}, \mathrm{l}-\mathrm{n}=10 \mu \mathrm{m}$. 


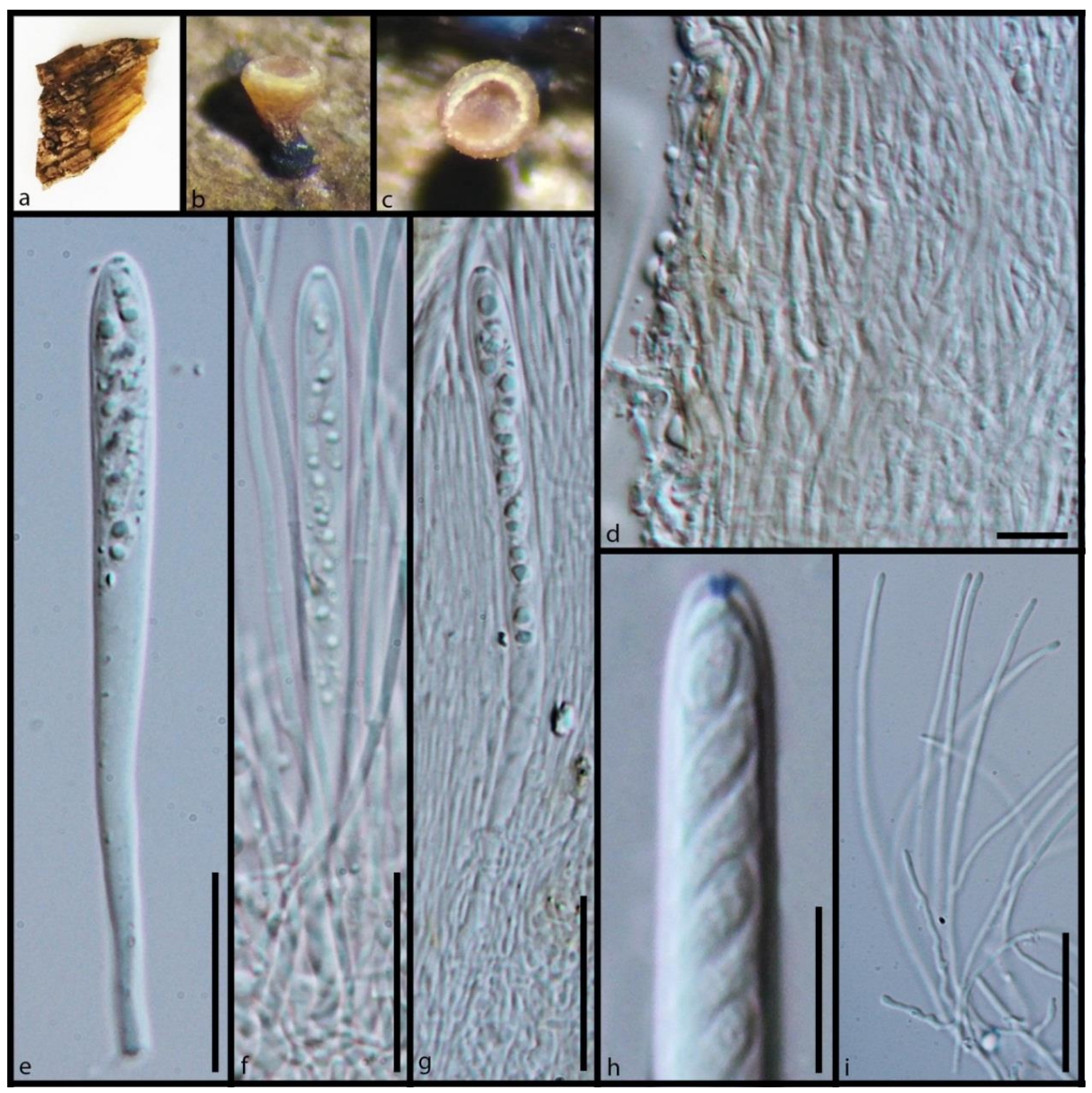

Figure 34 - Morphology of Hymenoscyphus cf. calyculus (MFLU 16-1865) a Substrate. b, c Apothecia on wood. $d$ Close up of the excipulum at flanks. e-g Cylindrical asci. h Amyloid ascus apex with ascospores. i Filiform paraphyses. Scale bars: $\mathrm{d}=10 \mu \mathrm{m}, \mathrm{e}=20 \mu \mathrm{m}, \mathrm{f}, \mathrm{g}, \mathrm{i}=20 \mu \mathrm{m}, \mathrm{h}=$ $10 \mu \mathrm{m}$.

\section{Lachnaceae (Nannf.) Raitv.}

Facesoffungi number: FoF 05904

Taxa are mostly saprobic and sometimes plant parasitic. Ascomata are apothecial and characterized by sessile or stipitate, cupulate or discoid receptacle. The margins and flanks are covered with hairs and hairs are cylindrical, septate and sometimes granulate. The ectal excipulum is composed of cells of textura angularis, textura prismatica or textura oblita and medullary excipulum is composed of cells of textura intricata or textura oblita. Paraphyses are filiform, lanceolate or rarely cylindrical. Asci are 8-spored, cylindric-clavate, amyloid or non-amyloid and sometimes arising from croziers. Ascospores are globose, ellipsoid to filiform or allantoid, septate or aseptate, hyaline and guttulate (Jaklitsch et al. 2016, Guatimosim et al. 2016, Chlebicki 1990, Šandová et al. 2018, Suková 2005, Perić \& Baral 2014, Ye et al. 2006, Hosoya et al. 2010, Zhuang \& Yu 2001, Han et al. 2014). Asexual morphs are pycnidial and conidia globose and aseptate (Jaklitsch et al. 2016).

Notes - Our phylogeny shows the genera Lasiobelonium, Trichopezizella, Solenopezia and Trichopeziza, which were previously classified under Lachnaceae, are not genetically related to this family. Similar phylogenetic placement of these genera was shown in the phylogenies of Guatimosim et al. (2016) and Pärtel (2016). Therefore, considering previous literature and results from our phylogeny, we remove these genera from Lachnaceae. 


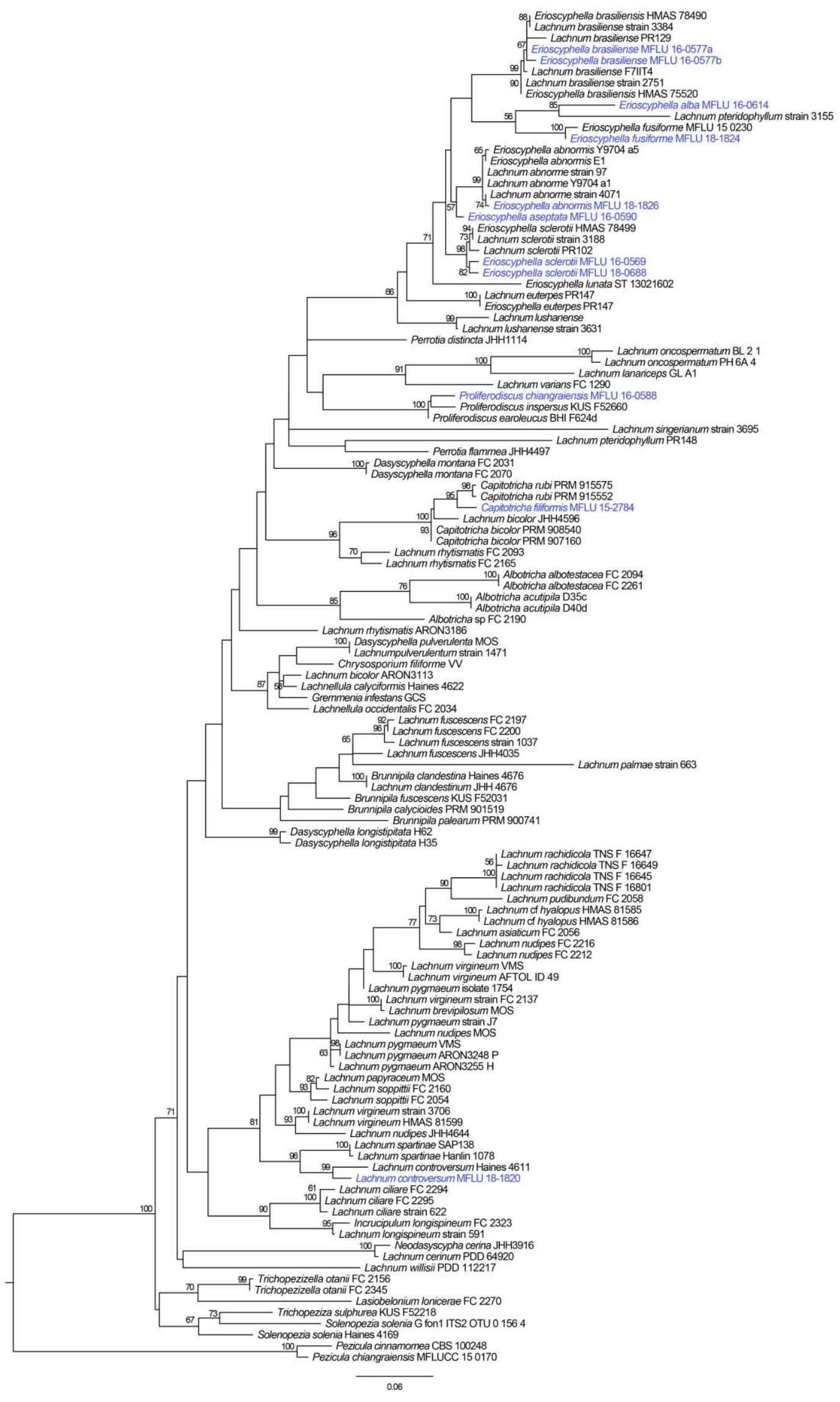

Figure 35 - Phylogram generated from maximum likelihood analysis of sequences of Lachnaceae based on ITS sequence data. MLBP values $\geq 50 \%$ are given near the nodes. Strain/culture numbers are given after the taxa. The tree is rooted with Pezicula chiangraiensis (MFLUCC 15 0170) and Pezicula cinnamomea (CBS 100248). 
Capitotricha filiformis Ekanayaka \& K.D. Hyde, sp. nov.

Index Fungorum number: IF556290; Facesoffungi number: FoF 05905; Fig. 36.

Etymology - refers to filiform paraphyses

Holotype - MFLU 15-2784

Saprobic on dead stems. Sexual morph: Apothecia 500-600 $\times 450-500 \mu \mathrm{m}$, arising singly, stipitate. Receptacle cupulate. Disc concave. Hairs $133-200 \times 2.5-4.5 \mu \mathrm{m}(\bar{x}=147.5 \times 3 \mu \mathrm{m}, \mathrm{n}=$ 30 ), cylindric, aseptate, thick-walled, hyaline to whitish, apices partially covered with granules. Ectal excipulum $15-20 \mu \mathrm{m}(\bar{x}=18 \mu \mathrm{m}, \mathrm{n}=10)$ in upper flanks, composed of thin-walled, hyaline cells of textura prismatica. Medullary excipulum 20-25 $\mu \mathrm{m}(\bar{x}=28 \mu \mathrm{m}, \mathrm{n}=10)$ in upper flanks, composed of thin-walled, hyaline cells of textura prismatica, cells in ectal excipulum are slightly wider than the cells in medullary excipulum. Hymenium hyaline. Paraphyses $2-4 \mu \mathrm{m}$ wide $(\bar{x}=$ $2.7 \mu \mathrm{m}, \mathrm{n}=20$ ), numerous, filiform, obtuse and slightly swollen at the apex, septate, not exceeding the asci in length, smooth, guttulate. Asci 50-65 $\times 7-9 \mu \mathrm{m}(\bar{x}=58.8 \times 7.7 \mu \mathrm{m}, \mathrm{n}=30), 8$-spored, unitunicate, cylindric-clavate, rounded and non-amyloid apex, short-stipitate base, croziers absent. Ascospores $10-12 \times 3-5 \mu \mathrm{m}(\bar{x}=11.2 \times 4.7 \mu \mathrm{m}, \mathrm{n}=40), 1-2$-seriate, ellipsoid, aseptate, hyaline. Asexual morph: Undetermined.

Material examined - Russia, Arkhangelsk region, Akhangelsk City, Maimaksansky City District, floodplain bushes, saprobic or weak parasitic on dead twigs of Rubus idaeus L. (Rosaceae), 1 May 2015, Gennady V. Okatov, T617 (MFLU 15-2784).

GenBank accessions - ITS- MK584992, SSU- MK585015

Notes - Our collection from Russia grouped with Capitotricha rubi with strong statistical support of $95 \%$ (Fig. 35). The ITS data of our collection shows similarity to C. rubi collections PRM:915575 (466/475-98\% with no gaps) and PRM:915552 (466/475-98\% with no gaps).

Capitotricha filiformis is characterized by stipitate, cupulate apothecia with long cylindrical hairs, filiform, cylindrical paraphyses, non-amyloid asci and ellipsoid ascospores. Capitotricha filiformis differ from other Capitotricha spp. by having filiform paraphyses with slightly swollen apices (Suková 2005).

Erioscyphella fusiforme Ekanayaka \& K.D. Hyde

= Lachnum fusiforme Ekanayaka \& K.D. Hyde

Facesoffungi number: FoF 00970; Fig. 37

Saprobic on dead stems. Sexual morph: Apothecia 435-440 × 378-382 $\mu \mathrm{m}(\bar{x}=437 \times 380$ $\mu \mathrm{m}, \mathrm{n}=10$ ), arising singly or in small groups, superficial, stipitate, white when fresh, covered with long, white hairs. Receptacle cupulate, disc concave, whitish to light yellow, margins white. Hairs 70-90 × 3-4 $\mu \mathrm{m}(79.4 \times 3.5 \mu \mathrm{m}, \mathrm{n}=30)$, on flanks and stipe, cylindrical or tapered to a blunt hemispherical tip, straight, thin-walled, septate, white, densely covered with colorless granules, occasionally tips are covered with a yellow to white resinous-appearing substance. Ectal excipulum 32-37 $\mu \mathrm{m}$ wide $(\bar{x}=35.5 \mu \mathrm{m}, \mathrm{n}=10)$, composed of hyaline cells of textura prismatica. Medullary excipulum 48-52 $\mu \mathrm{m}$ wide $(\bar{x}=51.1 \mu \mathrm{m}, \mathrm{n}=10)$, comprising hyaline cells of textura intricata. Hymenium hyaline. Paraphyses $1.5-2 \mu \mathrm{m}$ wide $(\bar{x}=1.7 \mu \mathrm{m}, \mathrm{n}=20)$, numerous, filiform, septate. Asci 47-52 $\times 4-4.5 \mu \mathrm{m}(\bar{x}=49.4 \times 4.2 \mu \mathrm{m}, \mathrm{n}=30)$, 8-spored, unitunicate, cylindrical, inoperculate, short stipitate base, amyloid, croziers absent. Ascospores $18-25 \times 1.5-2 \mu \mathrm{m}(\bar{x}=21.9$ $\times 1.6 \mu \mathrm{m}, \mathrm{n}=40$ ), biseriate, fusiform with sharp tips, hyaline, aseptate, smooth-walled, lacking sheath or appendages, with refractive inclusions. Asexual morph: Undetermined.

Material examined - China, Yunnan Province, Xishuangbanna, Jinghong, China, 9 June 2018, Zeng Ming, HC37 (MFLU 18-1824, HKAS102125).

GenBank accessions - LSU- MK591975, ITS- MK584948, RPB2- MK614728

Notes - Our new collection from China grouped with Erioscyphella fusiforme from Thailand with strong statistical support of $100 \%$ (Fig. 35). The ITS data of our collection shows $99 \%$ similarity to the type collection of E. fusiforme (MFLU 15-0230) (524/526-99\% with 2 gaps). 
The first record of E. fusiforme is from Thailand. Here we provide a new record of $E$. fusiforme from China. The new strain is morphologically and phylogenetically similar to the type specimen (Hongsanan et al. 2015).

This species previously introduced under the genus Lachnum (Hongsanan et al. 2015). However, in our phylogeny this species grouped within Erioscyphella clade. Therefore, we synonymize this species under the genus Erioscyphella.

Erioscyphella sclerotii (A.L. Sm.) Baral, Šandová \& B. Perić

$=$ Lachnum sclerotii (A.L. Sm.) J.H. Haines \& Dumont

Facesoffungi number: FoF 05907; Fig. 38

Saprobic on dead stems. Sexual morph: Apothecia $0.6-1 \times 1.2-1.5 \mathrm{~mm}$, arising singly or in small groups, superficial, stipitate, yellow when fresh, covered with long, brown hairs. Receptacle cupulate, disc concave and bright yellow, margins and flanks brown. Stipe hairy, medium to long in length. Hairs 35-60 ×3-5 $\mu \mathrm{m}(47 \times 3.7 \mu \mathrm{m}, \mathrm{n}=30)$, on flanks and stipe, cylindrical to blunt hemispherical tip, straight, thin-walled, septate, brown, densely covered with colorless granules. Ectal excipulum 35-40 $\mu \mathrm{m}$ wide $(\bar{x}=37.3 \mu \mathrm{m}, \mathrm{n}=10)$ in lower flanks, composed of brownish cells textura prismatica. Medullary excipulum $78-85 \mu \mathrm{m}$ wide $(\bar{x}=82 \mu \mathrm{m}, \mathrm{n}=10)$ in lower flanks, with few cell layers comprising hyaline cells of textura intricate, outer cells are tightly packed and inner cells are loosely packed. Hymenium hyaline. Paraphyses $2-2.5 \mu \mathrm{m}$ wide $(\bar{x}=2.3 \mu \mathrm{m}, \mathrm{n}=$ 10), numerous, filamentous, septate. Asci 70-80 × 6-7 $\mu \mathrm{m}(\bar{x}=78.9 \times 6.6 \mu \mathrm{m}, \mathrm{n}=30), 8$-spored, unitunicate, cylindrical, inoperculate, amyloid, short-stipitate base, sub-stipitate base. Ascospore 23-27 × 2.5-3 $\mu \mathrm{m}(\bar{x}=25.2 \times 2.8 \mu \mathrm{m}, \mathrm{n}=40)$, biseriate, fusiform, hyaline, 3-septate, smoothwalled, no sheath or appendages, sometimes with refractive inclusions. Asexual morph: Undetermined.

Material examined - Thailand, Chiang Rai Province, Mae Sai District, Pongpha, Tham Pla Temple M.14 (Bann Tham Pla Temple), on dead stem, 25 November 2014, A. H. Ekanayaka, HD002 (MFLU 16-0569), Thailand, Chiang Rai Province, Kun Korn water fall, 12 January 2018, A. H. Ekanayaka, HD72 (MFLU 18-0688).

GenBank accessions - MFLU 16-0569: LSU- MK591980, ITS- MK584951, SSUMK585033, RPB2- MK388219; MFLU 18-0688: LSU- MK591995, ITS- MK584969, SSUMK585042, RPB2- MK614726

Notes - Our two collections from Thailand grouped with Erioscyphella sclerotii (Fig. 35) and the clade received strong statistical support of $98 \%$. The ITS data of our collection shows similarity to Lachnum sclerotii (strain 3188) (528/534-99\% with 2 gaps). The LSU data of our collections is similar to L. abnorme collections, TNS:F-16617 (1080/1102-98\% with 1 gap) and KUS-F52080 (1077/1103-98\% with 3 gaps).

Erioscyphella sclerotii is characterized by having stipitate, cupulate, yellow apothecia, granulate cylindrical hairs, fusiform 3-septate ascospores (Smith 1901). Erioscyphella abnormis is similar to E. sclerotii but it has 7-septate ascospores (Spooner 1987).

Erioscyphella aseptata Ekanayaka \& K.D. Hyde, sp. nov.

Index Fungorum number: IF556291; Facesoffungi number: FoF 05908; Fig. 39.

Etymology - refers to aseptate ascospores

Holotype - MFLU 16-0590

Saprobic on dead stems. Sexual morph: Apothecia 845-930 $\times 250-285 \mu \mathrm{m}(\bar{x}=871.5 \times$ $267.9 \mu \mathrm{m}, \mathrm{n}=10$ ), arising singly or in small groups, sessile or short-stipitate, cupulate, bright yellow when fresh. Receptacle flat or slightly concave, disc bright yellow and the margins white when fresh, margins and flanks covered with hairs. Hairs 65-80 $\times 1.8-3.9 \mu \mathrm{m}(73.9 \times 2.8 \mu \mathrm{m}, \mathrm{n}=$ 30), on flanks and margins, cylindrical, straight, thin-walled, septate, white, densely covered with colorless granules. Ectal excipulum 19.6-31.6 $\mu \mathrm{m}(\bar{x}=25.6 \mu \mathrm{m}, \mathrm{n}=10)$ wide at margins and flanks, composed of large, thin-walled, hyaline cells of textura prismatica. Medullary excipulum composed of hyaline cells of textura intricata. Hymenium hyaline. Paraphyses 1.6-2.6 $\mu \mathrm{m}$ wide $(\bar{x}$ 
$=2.1 \mu \mathrm{m}, \mathrm{n}=20$ ), numerous, filiform, obtuse at the apex, septate, slightly branched at the base. Asci $70-100 \times 6.1-10.5 \mu \mathrm{m}(\bar{x}=90.8 \times 7.7 \mu \mathrm{m}, \mathrm{n}=30)$, unitunicate, cylindrical, inoperculate, amyloid, short-stipitate, arising from croziers. Ascospores $28.5-45.6 \times 1.8-3.5 \mu \mathrm{m}(\bar{x}=37.8 \times 2.4$ $\mu \mathrm{m}, \mathrm{n}=40$ ), multi-seriate, fusiform, hyaline, aseptate, row of guttules present, hyaline, smooth, thin-walled, no sheath or appendages, sometimes with refractive inclusions. Asexual morph: Undetermined.

Material examined - Thailand, Chiang Mai Province, Ban Mae Sae Nature Resource Park, 19 July 2015, A. H. Ekanayaka, HD029 (MFLU 16-0590).

GenBank accessions - LSU- MK591986, ITS- MK584957, RPB2- MK388223

Notes - Our strain HD029 formed an independent clade basal to Erioscyphella abnormis clade, with statistical support of 57\% (Fig. 35). The ITS region of Erioscyphella aseptata is similar to that of Lachnum abnorme (FC-2172) (791/821-96\% with 4 gaps). The LSU data of our strain is similar to L. abnorme (KUS-F52080) (793/797-99\% with no gaps) and similar to Erioscyphella lunata (S.T. 13021602) (781/797-98\% with no gaps). Erioscyphella aseptata is characterized by short-stipitate, cupulate, bright yellow apothecia covered by granulate, cylindrical hairs, cylindric, short pedicellate, amyloid asci and fusiform, aseptate ascospores. Erioscyphella aseptata is phylogenetically close to E. abnormis. However, E. abnormis and E. sclerotii differ from E. aseptata by having septate ascospores (Spooner 1987).

Erioscyphella brasiliensis (Mont.) Baral, Šandová \& B. Perić $=$ Lachnum brasiliense (Mont.) J.H. Haines \& Dumont

Facesoffungi number: FoF 05909; Fig. 40

Saprobic on dead stems. Sexual morph: Apothecia $0.8-1 \times 0.5-0.7 \mathrm{~mm}$, arising singly or in small groups, stipitate. Disc yellow, concave and smooth. Receptacle cupulate, concolorous, clothed with whitish or pale yellow hairs. Stipe cylindric, clothed with hairs. Hairs 32.3-40.1 $\times 2.5-3.2 \mu \mathrm{m}(\bar{x}=$ $35.4 \times 2.8 \mu \mathrm{m}, \mathrm{n}=20$ ), cylindric, septate, walls usually thin, surface finely granulate. Ectal excipulum 58-67 $\mu \mathrm{m}(\bar{x}=62.6 \mu \mathrm{m}, \mathrm{n}=10)$, composed of thin-walled, hyaline cells of textura prismatica. Medullary excipulum 57-72 $\mu \mathrm{m}(\bar{x}=62 \mu \mathrm{m}, \mathrm{n}=10)$, composed of narrow, thinwalled, hyaline cells of textura intricata. Hymenium hyaline. Paraphyses $1.5-2.5 \mu \mathrm{m}$ wide $(\bar{x}=2$ $\mu \mathrm{m}, \mathrm{n}=20)$, numerous, filiform, acute at the apex, non-septate. Asci 80-100 $\times 6-9.5 \mu \mathrm{m}(\bar{x}=89.8$ $\times 7.1 \mu \mathrm{m}, \mathrm{n}=30), 8$-spored, cylindric-clavate, unitunicate, tapered, conical at the apex, amyloid, stipitate base, croziers absent. Ascospores 20-35 $\times 2-3 \mu \mathrm{m}(\bar{x}=29 \times 2.8 \mu \mathrm{m}, \mathrm{n}=40)$, hyaline, narrowly fusoid, aseptate, lying in two or three overlapping series within the ascus. Asexual morph: Undetermined.

Material examined - Thailand, Chiang Rai Province, Doi Mae Salon, 12 March 2015, A. H. Ekanayaka, HD015, HD053 (MFLU 16-0577)

GenBank accessions - LSU- MK591993, ITS- MK584967, SSU- MK585040

Notes - Our strains HD015 and HD053 collected from Thailand are clustured with Erioscyphella brasiliensis group and the clade received high statistical support of 99\% (Fig. 35). Our strain shows close genetic relationship with E. brasiliensis collections from Europe (PR129) and China (HMAS 78490) (Fig. 35) and the relationship supported with moderate statistical support of $67 \%$ (MLBP).

The ITS data of our collection shows similarity to Lachnum brasiliense (strain 3384) (525/527-99\% with no gaps) and the LSU region shows similar to Erioscyphella curvispora (strain KL381) (790/805-98\% with no gaps) and to Lachnum abnorme (KUS-F52080) (930/959-97\% with 5 gaps).

Erioscyphella brasiliensis is characterized by yellow, cupulate apothecia covered with cylindrical, white hairs with finely granulate walls, filiform paraphyses with acute apices, amyloid asci arising from croziers and fusoid ascospores. Our collection is similar to the descriptions given by Spooner (1987) and Montagne (1856). 


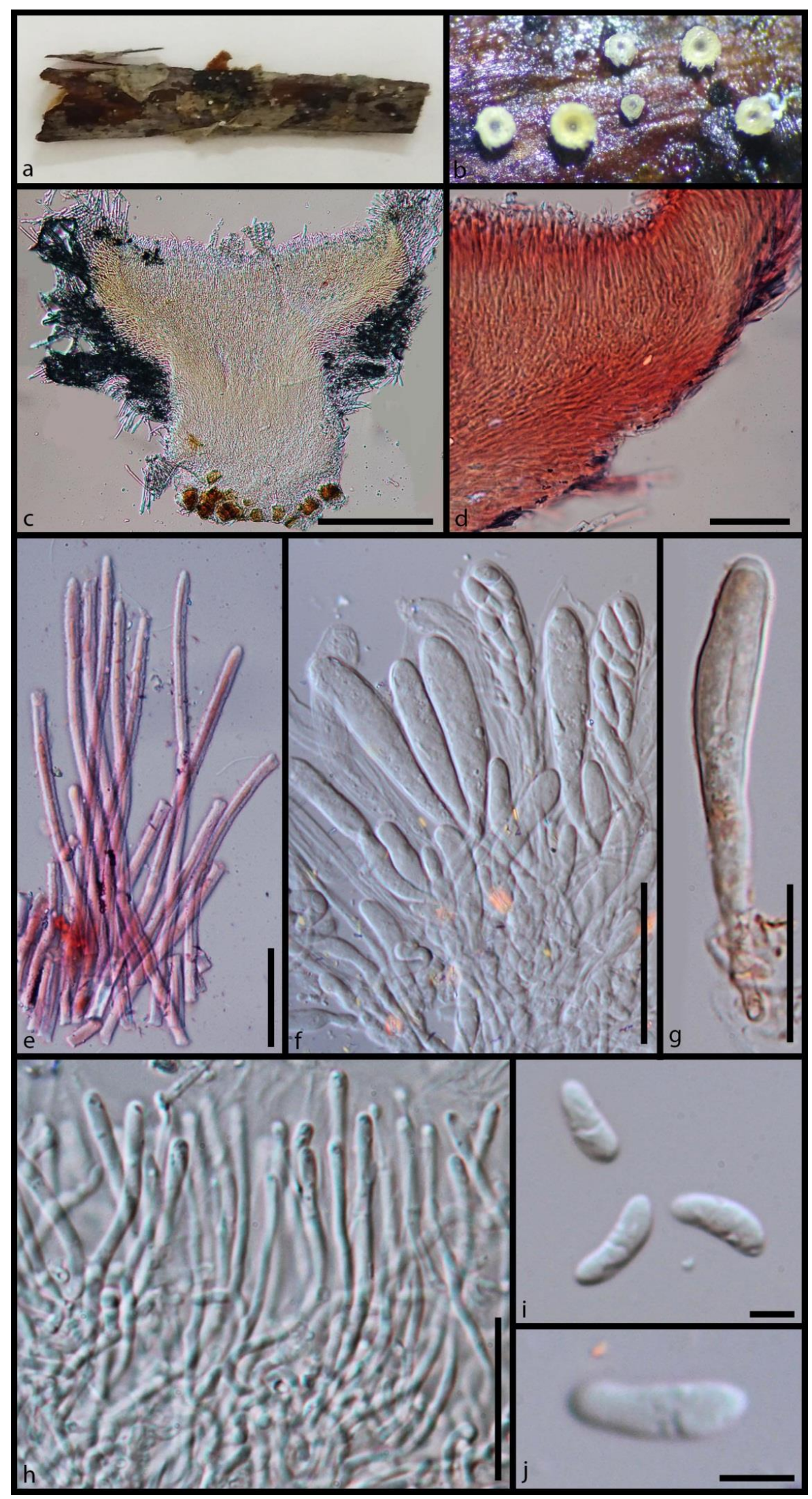

Figure 36 - Morphology of Capitotricha filiformis (MFLU 15-2784 holotype) a Substrate. b Apothecia on wood. c Cross section of an apothecium. d Close up of the cross section of apothecium at margins. e Long cylindrical hairs. $\mathrm{f}-\mathrm{g}$ Cylindric-clavate asci. h Filiform paraphyses. $\mathrm{i}-\mathrm{j}$ Ellipsoid ascospores. Scale bars: $\mathrm{c}=200 \mu \mathrm{m}, \mathrm{d}=30 \mu \mathrm{m}, \mathrm{e}=25 \mu \mathrm{m}, \mathrm{f}=30 \mu \mathrm{m}, \mathrm{g}-\mathrm{h}=20 \mu \mathrm{m}, \mathrm{i}-$ $\mathrm{j}=5 \mu \mathrm{m}$. 


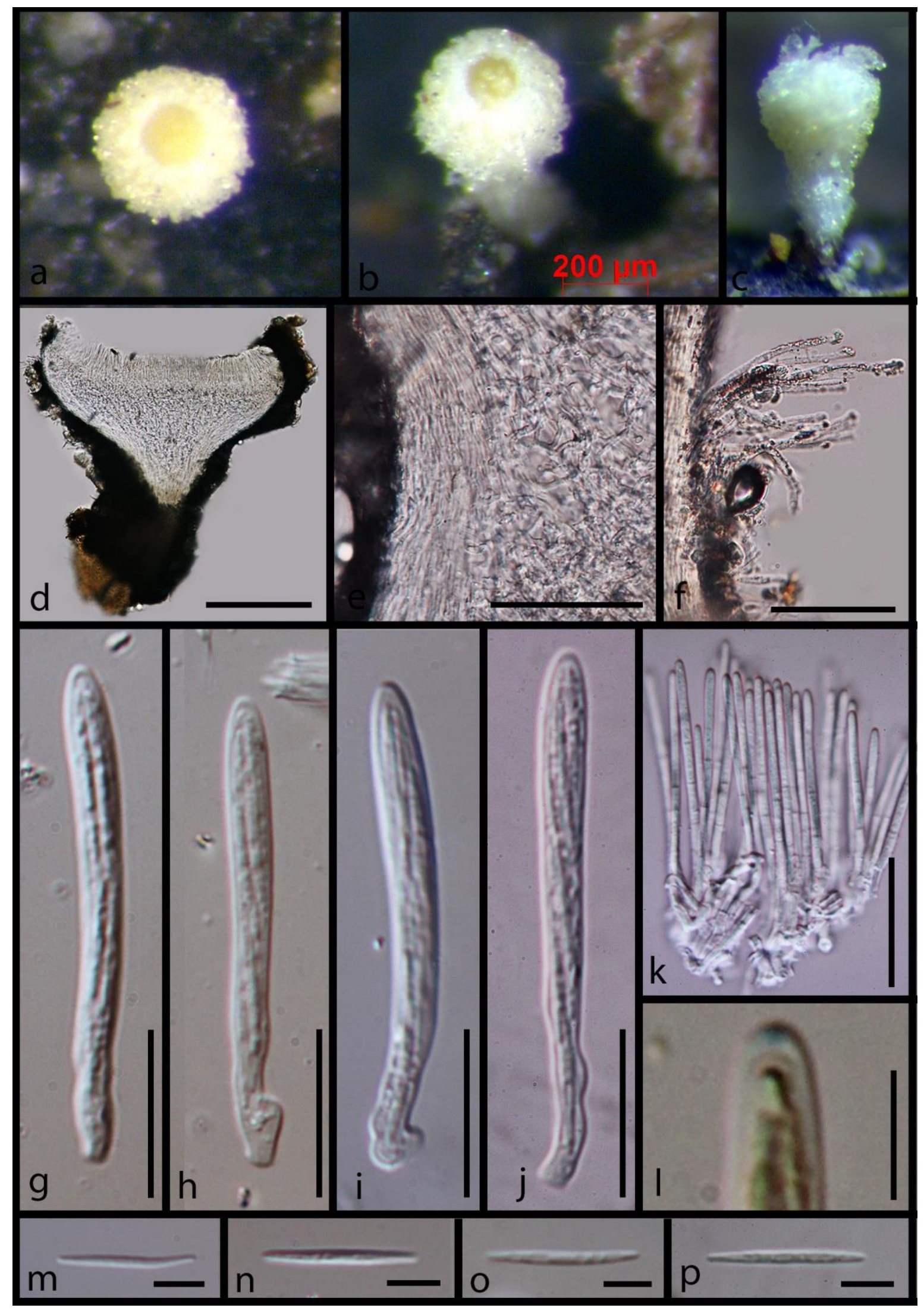

Figure 37 - Morphology of Erioscyphella fusiforme (MFLU 18-1824) a Apothecia on wood. b, c Apothecium on wood. $d$ Cross section of an apothecium. e Cylindrical hairs. $f$ Close up of the excipulum. g-j Short pedicellate asci. k Apex of the asci with the plug blueing in Melzer's reagent. 1 Septate paraphyses. $\mathrm{m}-\mathrm{p}$ Filiform ascospores. Scale bars: $\mathrm{b}, \mathrm{d}=200 \mu \mathrm{m}, \mathrm{e}=50 \mu \mathrm{m}, \mathrm{f}=30 \mu \mathrm{m}$, $\mathrm{g}-$ $\mathrm{j}=15 \mu \mathrm{m}, \mathrm{k}=30 \mu \mathrm{m}, \mathrm{l}-\mathrm{p}=5 \mu \mathrm{m}$. 


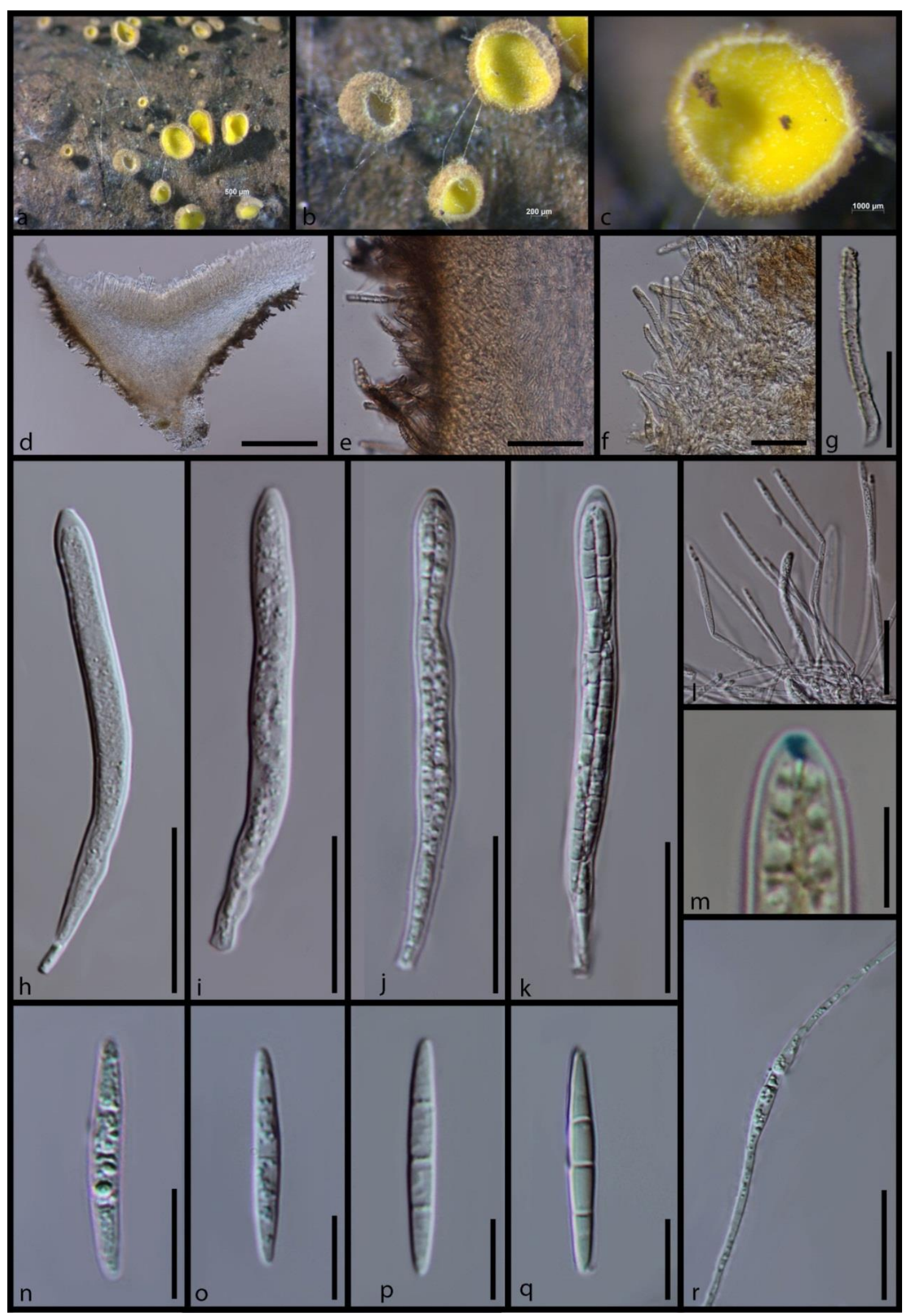

Figure 38 - Morphology of Erioscyphella sclerotii (MFLU 16-0569) a, b Apothecia in wood. c Apothecium in wood. d Cross section of a apothecium. e Close up of the peridium. $\mathrm{f}$ Setae on apothecium. g Septate seta in water. $\mathrm{h}-\mathrm{k}$ Asci in water. 1 Septate paraphyses in water. $\mathrm{m}$ Asci in Melzer's reagent with $\mathrm{J}+$ discoid apical apparatus. $\mathrm{n}-\mathrm{q}$ Fusiform ascospores in water. $\mathrm{r}$ Germinated ascospore. Scale bars: $\mathrm{a}=500 \mu \mathrm{m}, \mathrm{b}=20 \mu \mathrm{m}, \mathrm{c}=1000 \mu \mathrm{m}, \mathrm{d}=400 \mu \mathrm{m}, \mathrm{e}=50 \mu \mathrm{m}, \mathrm{f}-\mathrm{l}=25 \mu \mathrm{m}$, $\mathrm{m}=5 \mu \mathrm{m}, \mathrm{n}-\mathrm{q}=10 \mu \mathrm{m}, \mathrm{r}=25 \mu \mathrm{m}$. 


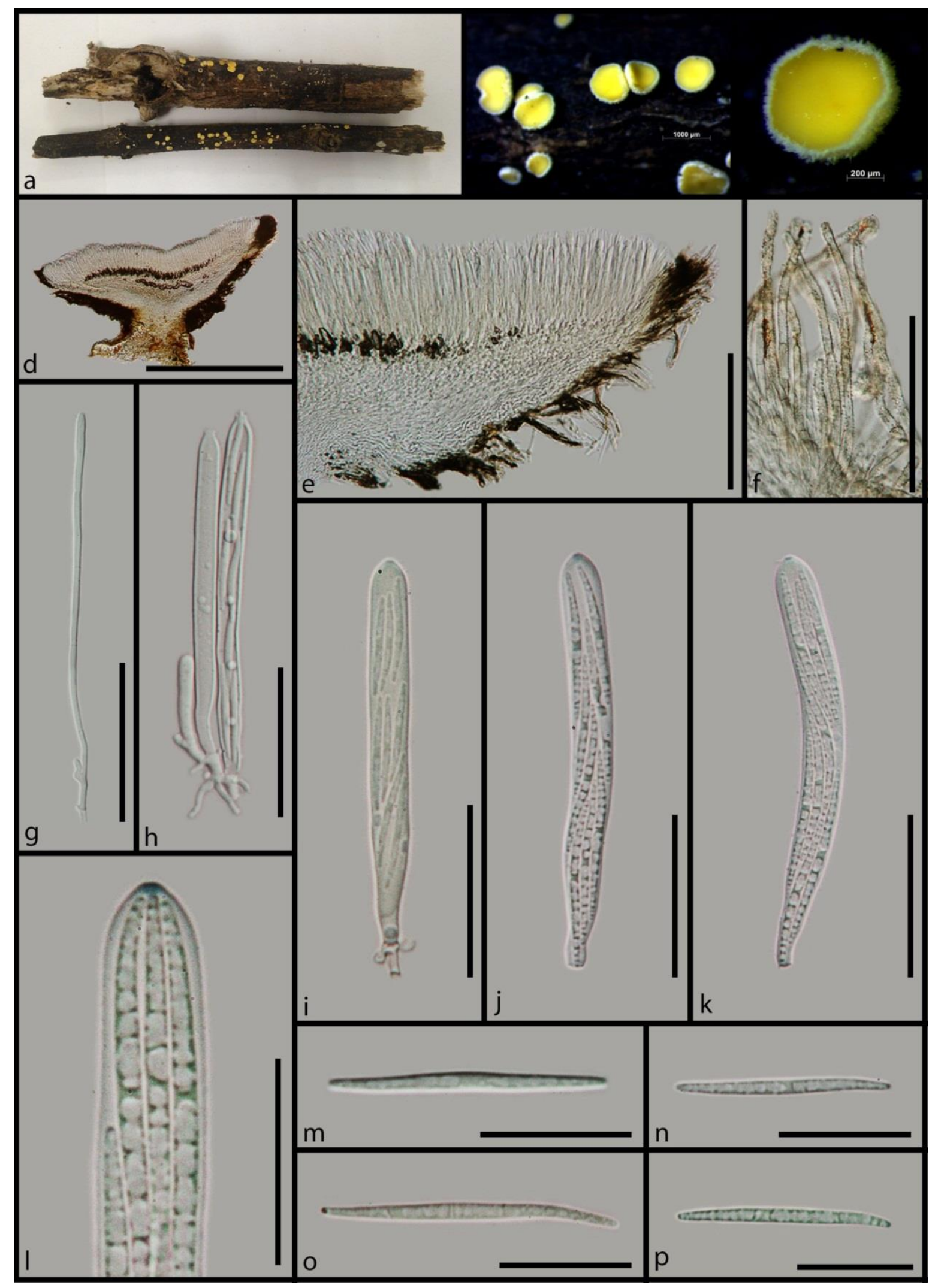

Figure 39 - Morphology of Erioscyphella aseptata (MFLU 16-0590 holotype) a Substrate. b Apothecia on wood. c Apothecium on wood. d Cross section of an apothecium. e Vertical section of apothecium at margins. f Cylindric hairs. g Septate, unbranched paraphyses. $\mathrm{h}-\mathrm{k}$ Short pedicellate asci. 1 Amyloid ring at apical apex (in Melzer's reagent). $m-p$ Fusiform ascospores. Scale bars: $\mathrm{b}=1000 \mu \mathrm{m}, \mathrm{c}=200 \mu \mathrm{m}, \mathrm{d}=500 \mu \mathrm{m}, \mathrm{e}=150 \mu \mathrm{m}, \mathrm{f}-\mathrm{g}=50 \mu \mathrm{m}, \mathrm{h}-\mathrm{k}=40 \mu \mathrm{m}, \mathrm{l}-\mathrm{p}=$ $20 \mu \mathrm{m}$. 


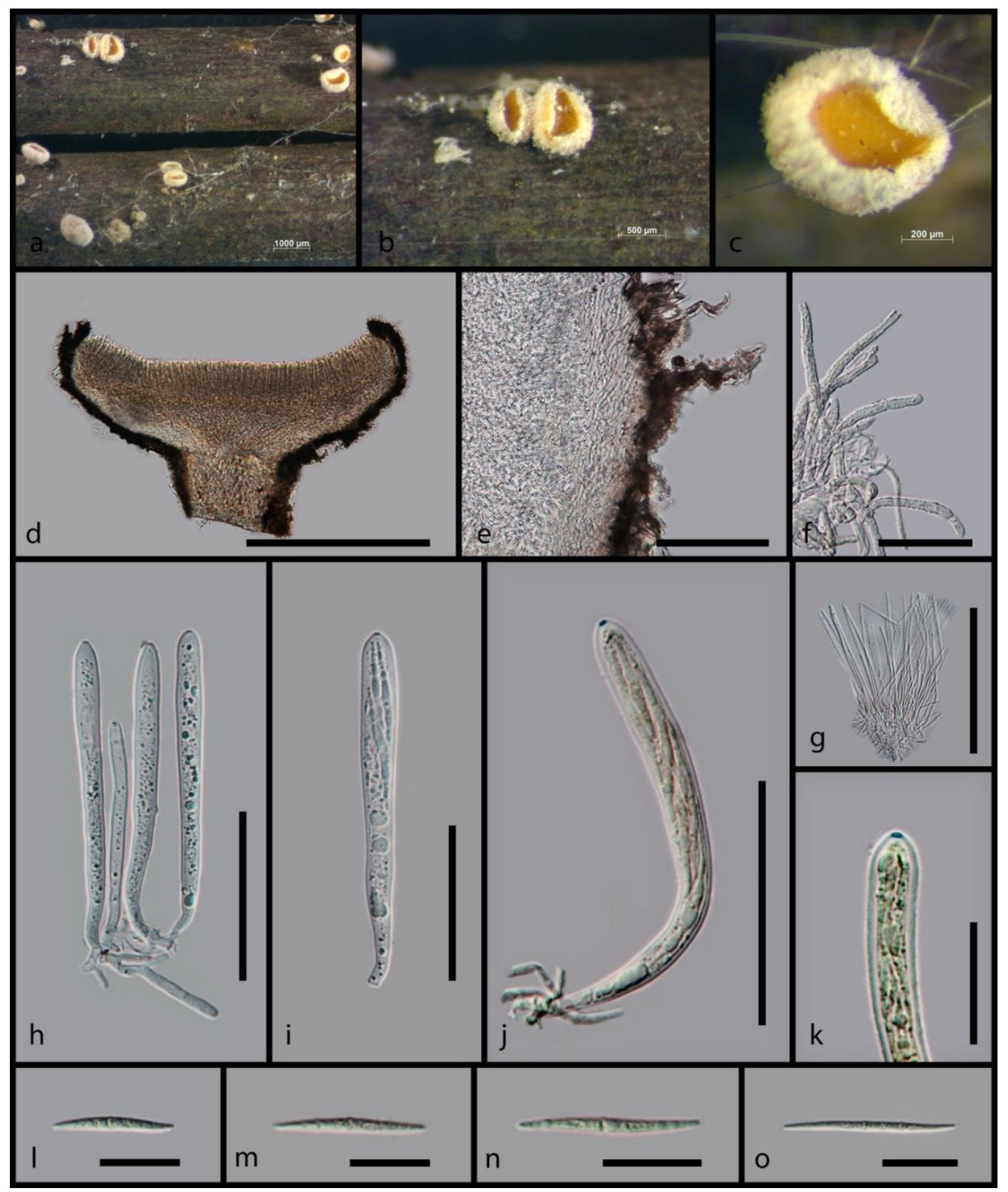

Figure 40 - Morphology of Erioscyphella brasiliense (MFLU 16-0577) a Substrate. b Apothecia on wood. c Close up of apothecium on wood. d Cross section of an apothecium. e Close up of a Vertical section of the apothecium at flanks. f Septate hairs. g Filiform paraphyses. $\mathrm{h}-\mathrm{j}$ Cylindric asci. $\mathrm{k}$ Amyloid ring at the ascus apex. $1-0$ Narrowly fusoid ascospores. Scale bars: $\mathrm{a}=1000 \mu \mathrm{m}, \mathrm{b}$ $=500 \mu \mathrm{m}, \mathrm{c}=200 \mu \mathrm{m}, \mathrm{d}=500 \mu \mathrm{m}, \mathrm{e}=100 \mu \mathrm{m}, \mathrm{f}=30 \mu \mathrm{m}, \mathrm{g}=100 \mu \mathrm{m}, \mathrm{h}-\mathrm{j}=45 \mu \mathrm{m}, \mathrm{k}=20 \mu \mathrm{m}$, $1-\mathrm{o}=15 \mu \mathrm{m}$.

Erioscyphella alba Ekanayaka \& K.D. Hyde, sp. nov.

Index Fungorum number: IF556292; Facesoffungi number: FoF 05910; Fig. 41.

Etymology - refers to white apothecia

Holotype - MFLU 16-0614

Saprobic on dead stems. Sexual morph: Apothecia $0.8-1 \times 0.6-0.9 \mathrm{~mm}$, arising singly or in small groups, stipitate, cupulate, white when fresh. Receptacle concave, disc pale yellow and the margins white when fresh, margins and flanks covered with hairs. Hairs 41.5-59.4 × 2.9-4.5 $\mu \mathrm{m}$ 
$(50.6 \times 3.5 \mu \mathrm{m}, \mathrm{n}=30)$, on flanks and margins, cylindrical, straight, thin-walled, septate, white to yellowish, densely covered with colorless granules. Ectal excipulum $28-32 \mu \mathrm{m}(\bar{x}=31.2 \mu \mathrm{m}, \mathrm{n}=$ 10) in lower flanks, composed of large, thin-walled, hyaline cells of textura prismatica. Medullary excipulum 38-44 $\mu \mathrm{m}(\bar{x}=42 \mu \mathrm{m}, \mathrm{n}=10)$ in lower flanks, composed of hyaline cells of textura intricata. Hymenium hyaline. Paraphyses $2.3-3.6 \mu \mathrm{m}$ wide $(\bar{x}=2.8 \mu \mathrm{m}, \mathrm{n}=20)$, numerous, lanceolate, septate. Asci 42.1-48.9 $\times$ 4.9-6.3 $\mu \mathrm{m}(\bar{x}=45.7 \times 5.6 \mu \mathrm{m}, \mathrm{n}=30)$, unitunicate, cylindrical, inoperculate, amyloid, short-stipitate base, arising from croziers. Ascospores 11.1-13.4 $\times 1.8-2.4 \mu \mathrm{m}(\bar{x}=12.3 \times 2.1 \mu \mathrm{m}, \mathrm{n}=40)$, multi-seriate, fusiform, hyaline, aseptate, row of guttules present, hyaline, smooth, thin-walled, no sheath or appendages, sometimes with refractive inclusions. Asexual morph: Undetermined.

Material examined - Thailand, Chiang Mai Province, Mushroom Research Center, 19 July 2015, A. H. Ekanayaka, HD034 (MFLU 16-0614).

GenBank accessions - LSU- MK591990, ITS- MK584965

Notes - Our strain HD034 grouped with Lachnum pteridophyllum with strong statistical support of $85 \%$ (Fig. 35). The ITS data of our collection is similar to that of Erioscyphella fusiforme (MFLU 15-0230) (460/495-93\% with 2 gaps) and to Lachnum pteridophyllum (strain $3155)$ (445/487-91\% with 4 gaps). The LSU data of our collection is similar to Lachnum abnorme (KUS-F52080) (791/801-99\% with no gaps).

Erioscyphella alba is similar to Lachnum pteridophyllum, but differs in having white apothecia covered with white hairs, slightly smaller asci and ascospores (Spooner 1987). Erioscyphella fusiforme is similar E. alba by having white apothecia covered with white hairs, but differs in having larger ascospores and filiform paraphyses (Hongsanan et al. 2015).

\section{Erioscyphella abnormis (Mont.) Baral, Šandová \& B. Perić}

= Lachnum abnorme (Mont.) J.H. Haines \& Dumont

Facesoffungi number: FoF 05911; Fig. 42.

Saprobic on dead stems. Sexual morph: Apothecia 1-2.5 $\times 0.5-1.3 \mathrm{~mm}$, arising singly, stipitate. Receptacle cupulate, brownish yellow, covered with hairs. Margin concolorous to receptacle, covered with hairs. Disc concave. Hairs $90-120 \times 3.5-5 \mu \mathrm{m}(\bar{x}=103 \times 4.7 \mu \mathrm{m}, \mathrm{n}=$ 30 ), cylindric, septate, walls rough and covered with granules, pigmented, light to dark brown. Ectal excipulum $40-55 \mu \mathrm{m}(\bar{x}=45 \mu \mathrm{m}, \mathrm{n}=10)$ in lower flanks, composed of thin-walled, slightly pigmented, light brown to hyaline cells of textura prismatica to angularis. Medullary excipulum 65-75 $\mu \mathrm{m}(\bar{x}=70 \mu \mathrm{m}, \mathrm{n}=10)$ in lower flanks, composed of thin-walled, hyaline cells of textura porrecta. Hymenium hyaline. Paraphyses $2.5-3.5 \mu \mathrm{m}$ wide $(\bar{x}=2.7 \mu \mathrm{m}, \mathrm{n}=20)$, numerous, filiform, conical apex, septate, sometimes exceeding the asci in length, smooth. Asci 80-95 $\times 8-11$ $\mu \mathrm{m}(\bar{x}=86.3 \times 9.4 \mu \mathrm{m}, \mathrm{n}=30), 8$-spored, unitunicate, cylindric-clavate, conical apex, amyloid, substipitate base, arising from croziers. Ascospores 40-65 $\times 1.5-2.5 \mu \mathrm{m}(\bar{x}=45.5 \times 1.8 \mu \mathrm{m}, \mathrm{n}=$ 40), multi-seriate, fusoid, 1-4-septate, hyaline, guttulate, tapered towards the base. Asexual morph: Undetermined.

Material examined - China, Yunnan Province, Xishuangbanna, Jinghong, 9 June 2018, Zeng Ming, HC39 (MFLU 18-1826, HKAS102127).

GenBank accessions - LSU- MK591977, ITS- MK584950, SSU- MK585049, RPB2MK614730

Notes - Our new collection HC39 from China clustered within Erioscyphella abnormis clade and the clade has strong statistical support of $99 \%$ (Fig. 35). The ITS and LSU data of our collection is 99\% similar to Lachnum abnorme specimens of KUS-F52080 (ITS: 807/843-96\% with 6 gaps, LSU: 1127/1128-99\% with 1 gap) and TNS:F-16617 (ITS: 791/801-99\% with no gaps).

Morphology of our collection is similar to the description of E. abnormis provided by Spooner (1987). However, all the observed ascospores were 1-4-septate and we did not observe 7septate ascospores as described for E. abnormis (Spooner 1987). Asci in our collection are slightly smaller than described for E. abnormis (Spooner 1987). Therefore, we assume that our collection is 
immature. Our collection is similar to E. australiense which is characterised by 1-3-septate ascospores, but E. australiense differs in having lanceolate paraphyses (Spooner 1987).

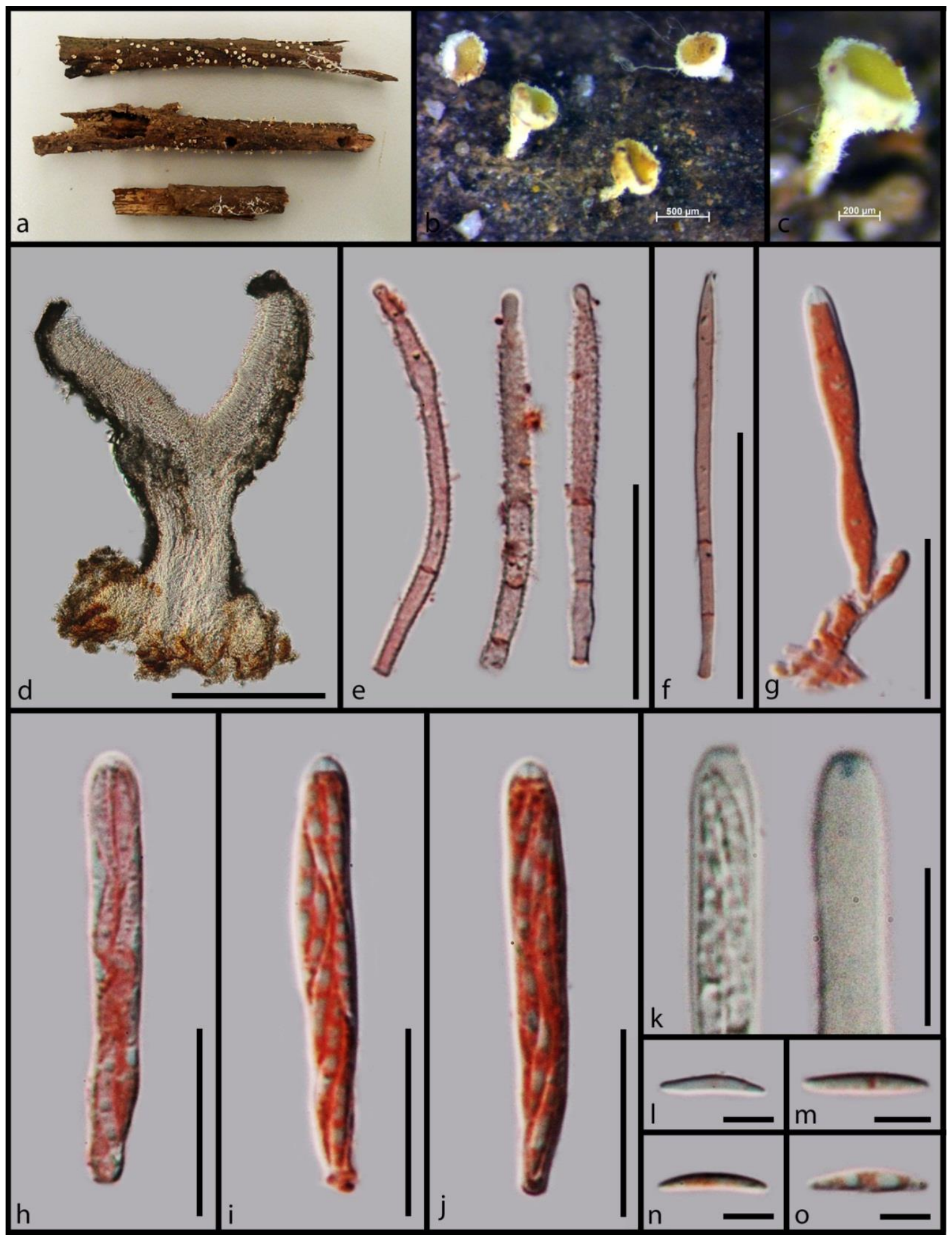

Figure 41 - Morphology of Erioscyphella alba (MFLU 16-0614 holotype) a Substrate. b Apothecia on wood. c Apothecium on wood. d Cross section of an apothecium. e Cylindric hairs (in congo red reagent). f Septate, unbranched paraphyses (in Congo red reagent). g-j Short pedicellate asci (in Congo red reagent). $\mathrm{k}$ Amyloid ring at apical apex (in Melzer's reagent). 1-o Fusiform ascospores (in Congo red reagent). Scale bars: $b=500 \mu \mathrm{m}, \mathrm{c}=200 \mu \mathrm{m}, \mathrm{d}=400 \mu \mathrm{m}, \mathrm{e}=$ $30 \mu \mathrm{m}, \mathrm{f}=40 \mu \mathrm{m}, \mathrm{g}-\mathrm{j}=20 \mu \mathrm{m}, \mathrm{k}=10 \mu \mathrm{m}, 1-\mathrm{o}=5 \mu \mathrm{m}$. 


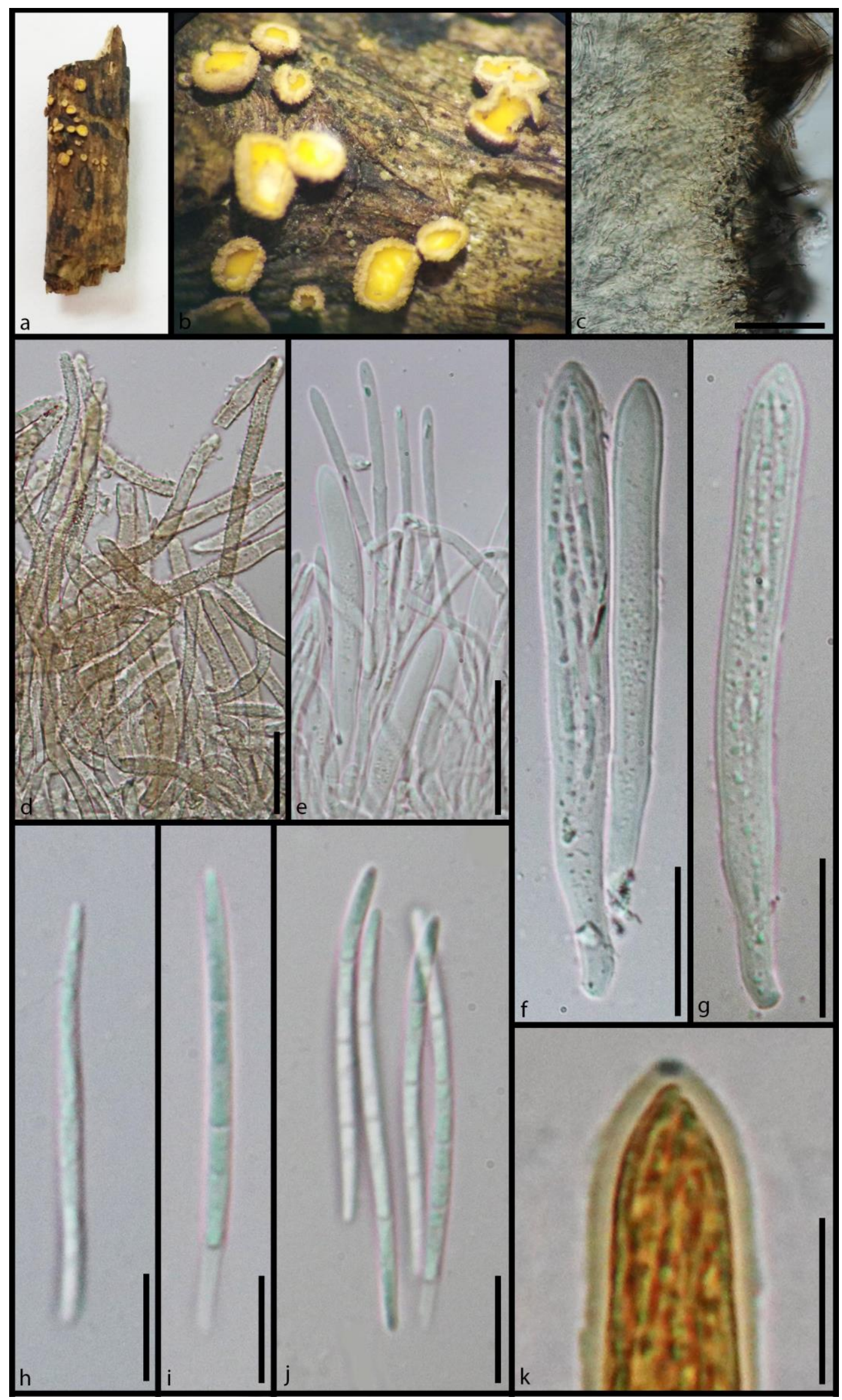

Figure 42 - Morphology of Erioscyphella abnormis (MFLU 18-1826) a Substrate. b Apothecia on wood. c Excipulum at margins. d Long cylindrical hairs. e Filiform paraphyses. f, g Cylindricclavate asci. $\mathrm{h}-\mathrm{j}$ Fusoid ascospores. $\mathrm{k}$ Amyloid ascus apex. Scale bars: $\mathrm{c}=50 \mu \mathrm{m}, \mathrm{d}, \mathrm{f}, \mathrm{g}=20 \mu \mathrm{m}$, e $=30 \mu \mathrm{m}, \mathrm{k}=10 \mu \mathrm{m}, \mathrm{h}-\mathrm{j}=5 \mu \mathrm{m}$. 
Proliferodiscus chiangraiensis Ekanayaka \& K.D. Hyde, sp. nov.

Index Fungorum number: IF556293; Facesoffungi number: FoF 05912; Fig. 43.

Etymology - refers to the Province where the holotype was collected

Holotype - MFLU 16-0588

Saprobic on dead stems. Sexual morph: Apothecia 710-780 $\times 320-350 \mu \mathrm{m}(\bar{x}=744.3 \times$ $327.6 \mu \mathrm{m}, \mathrm{n}=10)$. arising in small groups, sessile, white when fresh. Receptacle pulvinate, disc convex, orange when fresh. Hairs 35.5-40.1 ×3-3.6 $\mu \mathrm{m}(\bar{x}=38.2 \times 3.2 \mu \mathrm{m}, \mathrm{n}=30)$, cylindric, septate, hyaline, eguttulate, walls usually thin, surface finely granulate. Ectal excipulum 10-15 $\mu \mathrm{m}$ $(\bar{x}=12.6 \mu \mathrm{m}, \mathrm{n}=10)$ in upper flanks, composed of thin-walled, hyaline to yellowish cells of textura prismatica. Medullary excipulum $18-25 \mu \mathrm{m}(\bar{x}=21.7 \mu \mathrm{m}, \mathrm{n}=10)$ in upper flanks, composed of thin-walled, yellowish cells of textura prismatica. Hymenium yellow. Paraphyses 1.2-1.5 $\mu \mathrm{m}$ wide $(\bar{x}=1.33 \mu \mathrm{m}, \mathrm{n}=20$ ), numerous, filiform, obtuse at the apex, aseptate, not exceeding the asci in length, smooth, guttulate. Asci $27.5-32.3 \times 3.1-5.8 \mu \mathrm{m}(\bar{x}=30.3 \times 5.3 \mu \mathrm{m}, \mathrm{n}$ $=30$ ), 8 -spored, unitunicate, cylindric-clavate, rounded or medium conical at the apex, amyloid, stipitate base, arising from croziers. Ascospores 3.9-5.7 $\times 1.3-1.8 \mu \mathrm{m}(\bar{x}=4.7 \times 1.5 \mu \mathrm{m}, \mathrm{n}=40)$, 1-2-seriate, ellipsoid to fusoid, aseptate, hyaline. Asexual morph: Undetermined.

Material examined - Thailand, Chiang Rai Province, Doi Mae Salong, on dead stems, 22 June 2015, A.H. Ekanayaka, HD027 (MFLU 16-0588).

GenBank accessions - LSU- MK591985, ITS- MK584956, SSU- MK585037

Notes - Our new collection HD027 from Thailand grouped with Proliferodiscus earoleucus (BHI_F624d) and P. inspersus (KUS_F52660) and the clade with three Proliferodiscus spp. received high statistical support of $100 \%$ (Fig. 35). The ITS data of our collection is similar to that of $P$. earoleucus (BHI-F624d) (532/542-98 \% with 2 gaps) and to $P$. inspersus (KUS-F52660) (535/549-97\% with 4 gaps). The LSU data is similar to P. inspersus (KUS-F52660) (810/812-99\% with 2 gaps) and to $P$. tricolor (CBS 128288) (850/872-97\% with 5 gaps).

Proliferodiscus chiangraiensis is characterized by sessile apothecia with orange disk and margins covered by white granulate hairs, filiform, aseptate paraphyses, cylindric-clavate, amyloid asci and ellipsoid to fusoid ascospores. Proliferodiscus chiangraiensis is similar to P. earoleucus and $P$. inspersus. However, $P$. earoleucus differs from $P$. chiangraiensis by having non-amyloid asci and stipitate apothecia (Han et al. 2014). Proliferodiscus inspersus differs from $P$. chiangraiensis by having stipitate apothecia, paraphyses with slightly swollen apices and larger asci (Haines \& Dumont 1983, Han et al. 2014).

\section{Lachnum controversum (Cooke) Rehm}

Facesoffungi number: FoF 05913; Fig. 44.

Saprobic on dead stems. Sexual morph: Apothecia $1-2 \times 0.8-1.5 \mu \mathrm{m}$, arising singly, stipitate, orange-brown when rehydrated. Receptacle cupulate to discoid. Disc concave. Hairs 80$100 \times 2-3.5 \mu \mathrm{m}(\bar{x}=92.3 \times 2.8 \mu \mathrm{m}, \mathrm{n}=30)$, cylindric, aseptate, walls rough, granulate, brown, sometimes apices slightly swollen and have thin cylindrical outgrowth. Ectal excipulum 13-18 $\mu \mathrm{m}$ $(\bar{x}=15 \mu \mathrm{m}, \mathrm{n}=10)$ in upper flanks, composed of thin-walled, light brown to hyaline cells of textura prismatica. Medullary excipulum $11-16 \mu \mathrm{m}(\bar{x}=15 \mu \mathrm{m}, \mathrm{n}=10)$ in upper flanks, composed of thin-walled, hyaline cells of textura prismatica. Hymenium hyaline. Paraphyses $4-5 \mu \mathrm{m}$ wide $(\bar{x}$ $=4.6 \mu \mathrm{m}, \mathrm{n}=20$ ), numerous, filiform, lanceolate, conical apex, aseptate, smooth. Asci 40-55 $\times 3-6$ $\mu \mathrm{m}(\bar{x}=47.4 \times 4.5 \mu \mathrm{m}, \mathrm{n}=30), 8$-spored, unitunicate, cylindric-clavate, conical apex, amyloid, stipitate base, arising from croziers. Ascospores $6-8.5 \times 2-2.5 \mu \mathrm{m}(\bar{x}=7.4 \times 2.3 \mu \mathrm{m}, \mathrm{n}=40), 1-2$ seriate, fusoid, aseptate, hyaline, guttulate. Asexual morph: Undetermined.

Material examined - UK, Hedge End, on herbaceous stem, 3 March 2016, E.B.G. Jones, GJ239b (MFLU 18-1820).

GenBank accessions - LSU- MK591964, ITS- MK584937, SSU- MK585025, RPB2MK368613

Notes - Our collection of GJ239b from UK grouped with a Japanese collection of $L$. controversum (Haines 4611) with strong statistical support of 99\% (Fig. 35). The ITS data of our 
collection is similar to that of Lachnum controversum (JHH4611) (521/536-97\% with 2 gaps) and to L. virgineum (CBS 234.54) (512/553-93\% with 2 gaps). The LSU data of our species is similar to L. pudibundum (CBS 577.73) (885/896-99\% with 8 gaps) and to L. virgineum (CBS 234.54) (877/894-98\% with 5 gaps).

Morphology of our collection is in agreement with the description by Spooner (1987) and, therefore, we determine it as L. controversum.

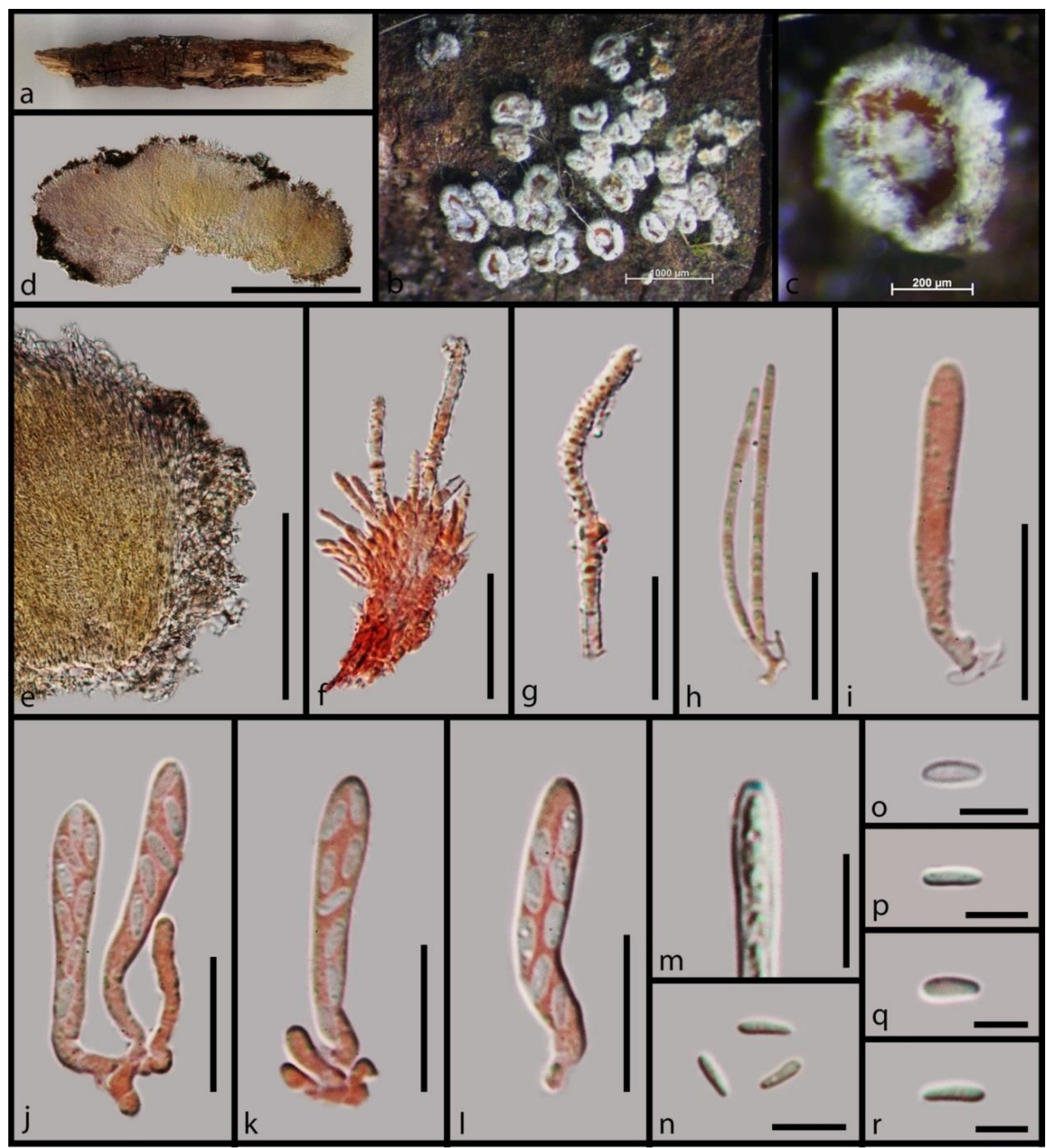

Figure 43 - Morphology of Proliferodiscus chiangraiensis (MFLU 16-0588 holotype) a Substrate. b Apothecia on wood. c Apothecium on wood. $d$ Cross section of an apothecium. e Close up of the cross section of apothecium at margins. f, g Long cylindrical hairs (in congo red reagent). $h$ Cylindrical paraphyses (in congo red reagent). $\mathrm{i}-1$ Cylindric-clavate asci (in congo red reagent). $\mathrm{m}$ Apex of the asci with the plug blueing in Melzer's reagent. n-r Fusoid ascospores (in congo red reagent). Scale bars: $b=1000 \mu \mathrm{m}, \mathrm{c}=200 \mu \mathrm{m}, \mathrm{d}=300 \mu \mathrm{m}, \mathrm{e}=100 \mu \mathrm{m}, \mathrm{f}=20 \mu \mathrm{m}, \mathrm{g}-\mathrm{l}=15 \mu \mathrm{m}$, $\mathrm{m}=10 \mu \mathrm{m}, \mathrm{n}-\mathrm{r}=5 \mu \mathrm{m}$. 


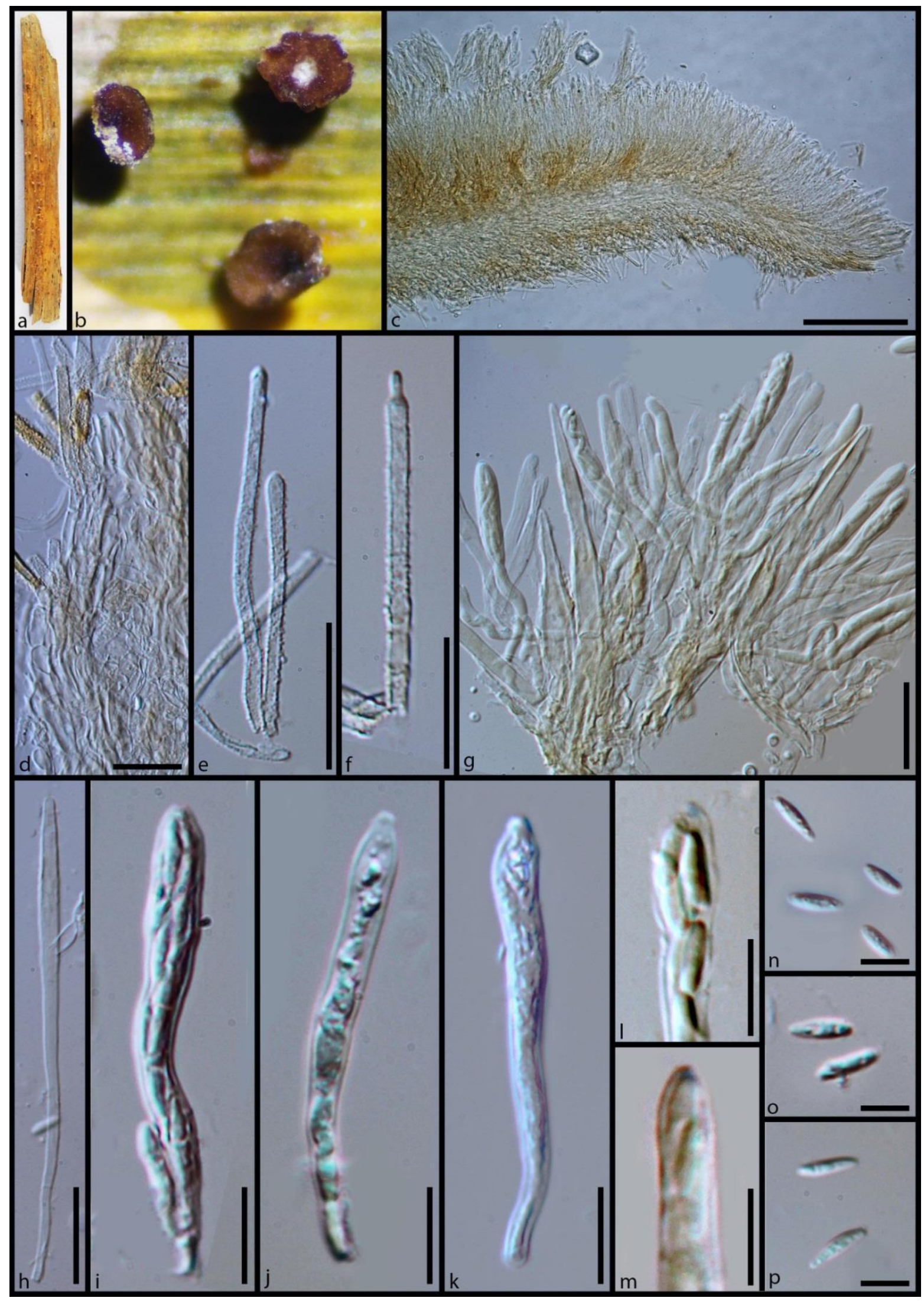

Figure 44 - Morphology of Lachnum controversum (MFLU 18-1820) a Substrate. b Rehydrated apothecia on wood. c Close up of the cross section of apothecium at margins. d Hairs and excipular cells at flanks. e Cylindrical hairs. f Cylindrical hairs with apices containing thin cylindrical outgrowth. $\mathrm{g}$ Asci and paraphyses. $\mathrm{h}$ Lanceolate paraphyses. i-k Cylindric-clavate asci. $1, \mathrm{~m}$ Amyloid asci apices in Melzer's reagent. $\mathrm{n}-\mathrm{p}$ Fusoid ascospores. Scale bars: $\mathrm{c}=100 \mu \mathrm{m}, \mathrm{d}-\mathrm{g}=20$ $\mu \mathrm{m}, \mathrm{h}-\mathrm{m}=10 \mu \mathrm{m}, \mathrm{n}-\mathrm{p}=5 \mu \mathrm{m}$. 


\section{Bulgariella clade}

Facesoffungi number: FoF 05914

Taxa are saprobic. Ascomata are apothecial or rarely cleistothecial. Apothecia are cupulate, discoid, turbinate or capitate and sessile or stipitate. The margins and flanks are covered with hairs and hairs are cylindrical, sometimes pigmented which dissolve in $\mathrm{KOH}$ and septate. The ectal excipulum is composed of cells of textura angularis, textura prismatica or textura oblita, sometimes granulate and medullary excipulum is composed of cells of textura intricata or textura oblita and sometimes gelatinized. Paraphyses are filiform, lanceolate or cylindrical and rarely absent. Asci are 8-spored, cylindric-clavate, amyloid or non-amyloid, sometimes arising from croziers and sometimes evanescent. Ascospores are globose, ellipsoid to filiform, septate or aseptate, hyaline or brownish and guttulate (Dennis 1956, Iturriaga et al. 2017, Kohn 1989, Plishka et al. 2008, Gamundi 1977). Asexual morphs are rarely recorded and they are pycnidial and multilocular. Conidiogenous cells are cylindrical and hyaline. Conidia are dark brown with a protruding base and longitudinal striation (Sutton 1980).

Notes -Bulgariella, Chlorovibrissea, Connersia, Mitrulinia, Pleuroascus and Pseudomitrula, were previously placed within the other helotilian families. In our phylogenetic analysis, we have noticed that they are having a close phylogenetic affiliation to Lachnaceae and Helotiaceae. Iturriaga et al. (2017) showed the phylogenetic relationship of Bulgariella close to Lachnaceae, and Chlorovibrissea clustered close to Lachnaceae taxa within the phylogenetic analysis of Zheng \& Zhuang (2017a). Suh \& Blackwell (1999) showed that Pleuroascus and Connersia are genetically closely related. Therefore, considering previous literature and results from our phylogeny, we place these genera under a separate clade. The asexual genus Endomelanconium is assigned to the sexual genus Bulgariella (Fenwick 1992).

Solenopeziaceae Ekanayaka \& K.D. Hyde, fam. nov.

Index Fungorum number: IF556294; Facesoffungi number: FoF 05915

Type genus - Solenopezia

Saprobic. Sexual morphs: Ascomata apothecial cupulate, discoid or pulvinate, sessile or stipitate, sometimes covered with hyaline, whitish, yellow or brown, non-bristle-like hairs. Ectal excipulum composed of cells of textura angularis, textura prismatica or textura oblita. Medullary excipulum composed of cells of textura intricata or textura oblita. Paraphyses filiform, lanceolate or cylindrical. Asci 8-spored, cylindric-clavate, amyloid or non-amyloid, sometimes arising from croziers. Ascospores globose, ellipsoid to fusiform, septate or aseptate, guttulate. Asexual morphs: Conidiomata hyphomycetous. Conidiophores simple, sparsely branched or absent. Conidiogenous cells cylindrical to subclavate, sometimes apically slightly swollen. Conidia hyaline or black, septate, branched, lunate, sometimes formed in a chain and becoming tortuous and appearing as terminal dictyospores, rarely appendaged.

Notes - The genera Geniculospora Tricladium, Graddonia, Mycofalcella, Halenospora, Trichopeziza, Lasiobelonium, Trichopezizella, and Solenopezia, which were previously assigned to the other helotilian families, formed a monophyletic clade close to Helotiaceae and Lachnaceae. However, this clade did not receive strong statistical support.

Jaklitsch et al. (2016) suggested that Trichopeziza, Trichopezizella and Solenopezia require a family of their own based on excipular and hair characteristics, and absence of an apothecial stipe, and Guatimosim et al. (2016) and Pärtel (2016) showed that they are genetically closely related to each other and formed a monophyletic clade, but placed away from their former family Lachnaceae. Therefore, considering previous literature and our results from phylogenetic analysis we introduce the new family Solenopeziaceae.

\section{Colipila clade}

Taxa are saprobic on dead plant material (Baral et al. 2012). Ascomata are apothecial and cupulate and covered with long cylindrical hairs. The ectal excipulum is composed of cells of textura prismatica. Paraphyses are dimorphic, sub-cylindrical and not exceeding the length of asci, 
or broadly lanceolate and exceeding the length of asci. Asci are cylindric-clavate, 8-spored, amyloid and arising from croziers. Ascospores are ellipsoid to fusoid (Baral et al. 2012). Asexual morphs are not recorded (Baral et al. 2012).

Notes - The genus Colipila was introduced by Baral et al. (2012) to accommodate two species, C. masduguana and C. pilatensis. In our phylogenetic analysis this genus forms a separate clade close to Lachnaceae and Helotiaceae clade.

\section{LAHMIALES}

This order was introduced by Eriksson (1986). Raitviir \& Spooner (1994) suggested several phylogenetic positions for this order within Dothideomycetes (Patellariaceae and Acrospermaceae) and Lecanoromycetes (Odontotremataceae). Later Jaklitsch et al. (2016) placed it within Leotiomycetes according to its morphology.

\section{Lahmiaceae O.E. Erikss.}

Facesoffungi number: FoF 05916

Taxa are saprobic or plant pathogenic (Eriksson 1986). Ascomata are apothecial and characterized by shape, stipitate, black turbinate receptacle which is closed when immature and opening by irregular radial splits at maturity. The ectal excipulum is composed of strongly melanized cells of textura epidermoidea and medullary excipulum is composed of strongly gelatinized cells of textura epidermoidea. Paraphysoids are densely septate, unbranched and slightly swollen at apices. Asci are 8-spored, cylindric-clavate, non-amyloid, arising from croziers and bitunicate but non-fissitunicate. Ascospores are hyaline, crescent-shaped and 1-4-septate. Asexual morphs are hyphomycetous and phialidic. Conidia are falcate and 1-3-septate (Eriksson 1986).

Notes - This family does not have any available sequence data. Therefore, we are unable to provide a stable phylogenetic position for this family and keep it under Leotiomycetes incertae sedis following Jaklitsch et al. (2016).

\section{LAURIOMYCETALES}

This order was introduced by Hernandez-Restrepo et al. (2017). This is the most basal clade of Leotiomycetes. Its basal position was also shown in Hernandez-Restrepo et al. (2017).

\section{Lauriomycetaceae Hern.-Restr., R.F. Castañeda \& Guarro}

Facesoffungi number: FoF 05917

Taxa are saprobic. Sexual morphs are not recorded. Asexual morphs are hyphomycetous synnematous. Conidiophores are macronematous, mononematous, straight or flexuous, thick and smooth-walled, brown to dark brown and paler toward the slightly swollen rounded and thin-walled apex. Conidiogenous cells are blastic, discrete, terminal and hyaline. Conidia are unicellular, hyaline to subhyaline, thin- and smooth-walled, in acropetal chains and ellipsoid to cylindrical or obclavate, in one or several tiers (Somrithipol et al. 2017, 2006, Crous \& Wingfield 1994, Hernandez-Restrepo et al. 2017).

Notes - This family includes single genus: Lauriomyces and it forms a well-supported clade at the basal position in Leotiomycetes.

\section{LEOTIALES}

The order Leotiales was introduced by Korf \& Lizon (2001). Formerly this order included the single family Leotiaceae.

\section{Gelatinomyces clade}

Facesoffungi number: FoF 05918

Taxa are saprobic on soil or dead plant material. Ascomata are apothecial. Apothecia are aggregated (but well separated) in a single stroma, pale grey to dark coloured, soft gelatinous, 
translucent, globose or pulvinate when young, discoid to cupulate with maturity and sessile. The exciple is dark and gelatinous. The hymenial surface is covered with a gelatinous layer. Paraphyses are simple and branched. Asci are multi-spored, cylindrical, tapered at the base and non-amyloid. Ascospores are minute, hyaline, globose to ovoid and smooth-walled (Sanoamuang et al. 2013). Asexual morphs are hyphomycetous. Conidiophores are hyaline. Conidiogenous cells are two types, very short conidiogenous cells on hyphal cells, or longer conidiogenous cells at branching points. Conidia are ovoid, minute and powdery with age (Sanoamuang et al. 2013).

Notes - This genus is distinct from other taxa (Flagellospora, Leotiaceae, Lichinodiaceae and Tympanidaceae) in the clade except Myriodiscus by having gelatinized aggregated apothecia attached to a central stroma. Jaklitsch et al. (2016) considered Gelatinomyces as a synonym of Myriodiscus. In the outline of Wijayawardene et al. (2018), Gelatinomyces was placed in Leotiomycetes genera incertae sedis, while Myriodiscus was placed in Tympanidaceae. However, we are unable to provide the genetic relationship of Myriodiscus and Gelatinomyces as there is no sequence data available for Myriodiscus. Therefore, according to our phylogeny and previous literature regarding morphological characters, we suggest this genus needs to be given a new family name when more information is available.

\section{Leotiaceae Corda}

Facesoffungi number: FoF 05986

Taxa are saprobic on soil or dead plant material. Ascomata are apothecial. Apothecia are clavate, turbinate to applanate, sessile to long-stipitate with subglobose to ellipsoid to fusoid fertile part and sometimes gelatinous. The ectal excipulum is composed of cells of textura intricata or textura porrecta, mostly gelatinized and medullary excipulum is composed of cells of textura intricata and mostly non-gelatinized. The hymenium is hyaline to greenish or yellowish. Paraphyses are filiform, sometimes apically slightly swollen and/or branched, straight to slightly curved, aseptate, hyaline and sometimes pigmented with loose exudates. Asci are 8-spored, mostly amyloid and arising from croziers. Ascospores are ellipsoid to fusoid, rarely vermiform, guttulate, aseptate and hyaline (Lizon et al. 1998, Kučera et al. 2014, 2017, Ohenoja et al. 2010). Asexual morphs are not recorded.

Notes - This family formed a monophyletic clade sister to Lichinodiales. Pezoloma and Halenospora were previously classified within Leotiaceae, but according to our phylogenetic analysis they are not genetically related to Leotiaceae. Therefore, in here we remove these genera from Leotiaceae and transferred to Discinellaceae (Pezoloma) and Tricladium-Solenopezia clade (Halenospora).

Microglossum macrosporum Ekanayaka \& K.D. Hyde, sp. nov.

Index Fungorum number: IF556295; Facesoffungi number: FoF 05919; Fig. 46.

Etymology - refers to large ascospores

Holotype - MFLU 18-1830

Saprobic on soil. Sexual morph: Apothecia 10-20 × 1-5 mm, arising singly, stipitate, greenish brown when fresh and brown when dry. Receptacle clavate. Medullary tissue composed of, thin-walled, hyaline cells of textura prismatica. Hymenium hyaline. Paraphyses $2.5-3.2 \mu \mathrm{m}$ wide $(\bar{x}=2.8 \mu \mathrm{m}, \mathrm{n}=20)$, numerous, filiform, obtuse and slightly swollen at the apex, aseptate, smooth, aguttulate. Asci $85-105 \times 10-12.5 \mu \mathrm{m}(\bar{x}=91.4 \times 11.2 \mu \mathrm{m}, \mathrm{n}=30)$, arising from croziers, 8-spored, unitunicate, cylindric-clavate, apex rounded and amyloid, short stipitate base. Ascospores 50-75 $\times 4.5-5.5 \mu \mathrm{m}(\bar{x}=64 \times 4.7 \mu \mathrm{m}, \mathrm{n}=40)$, multi-seriate, fusoid, curved, aseptate, hyaline, guttulate. Asexual morph: Undetermined.

Material examined - Thailand, Chiang Rai Province, Chiang Sen, 14 July 2015, A. H. Ekanayaka, HD52 (MFLU 18-1830).

GenBank accessions - LSU- MK591992, RPB2- MK614724

Notes - According to our phylogenetic analysis, Microglossum is polyphyletic within Leotiales (Fig. 45). Our strain of Microglossum grouped basal to other Microglossum species in 
clade 1 and is a well-supported clade (100\%). The LSU data of our strain is similar to that of Thuemenidium atropurpureum (strain 1136126) (775/792-98\% with no gaps) and to Microglossum olivaceum (KL220) (770/800-96\% with 2 gaps) and Microglossum viride (strain 1132541) (770/800-96\% with 2 gaps). The RPB2 region of our species is similar to that of Microglossum rufum (AFTOL-ID 1292) (874/950-92\% with 10 gaps).

Microglossum macrosporum is similar to M. nudipes, M. parvisporum, M. rufescens and $M$. cyanobasis, but differs in having larger ascospores (Kucera et al. 2014).

Microglossum viride and M. griseoviride formed a basal clade (Microglossum II clade, Fig. 45) within Leotiales and they differ from other Microglossum spp. by having a squamulose stipe (other Microglossum spp. have a naked stipe) (Kucera et al. 2014). Therefore, we suggest that $M$. viride and $M$. griseoviride require a new generic name within Leotiaceae.

Thuemenidium differs from Microglossum by having black or dark coloured apothecia (Ohenoja et al. 2010). Our phylogeny shows that Thuemenidium is also polyphyletic within Leotiales.

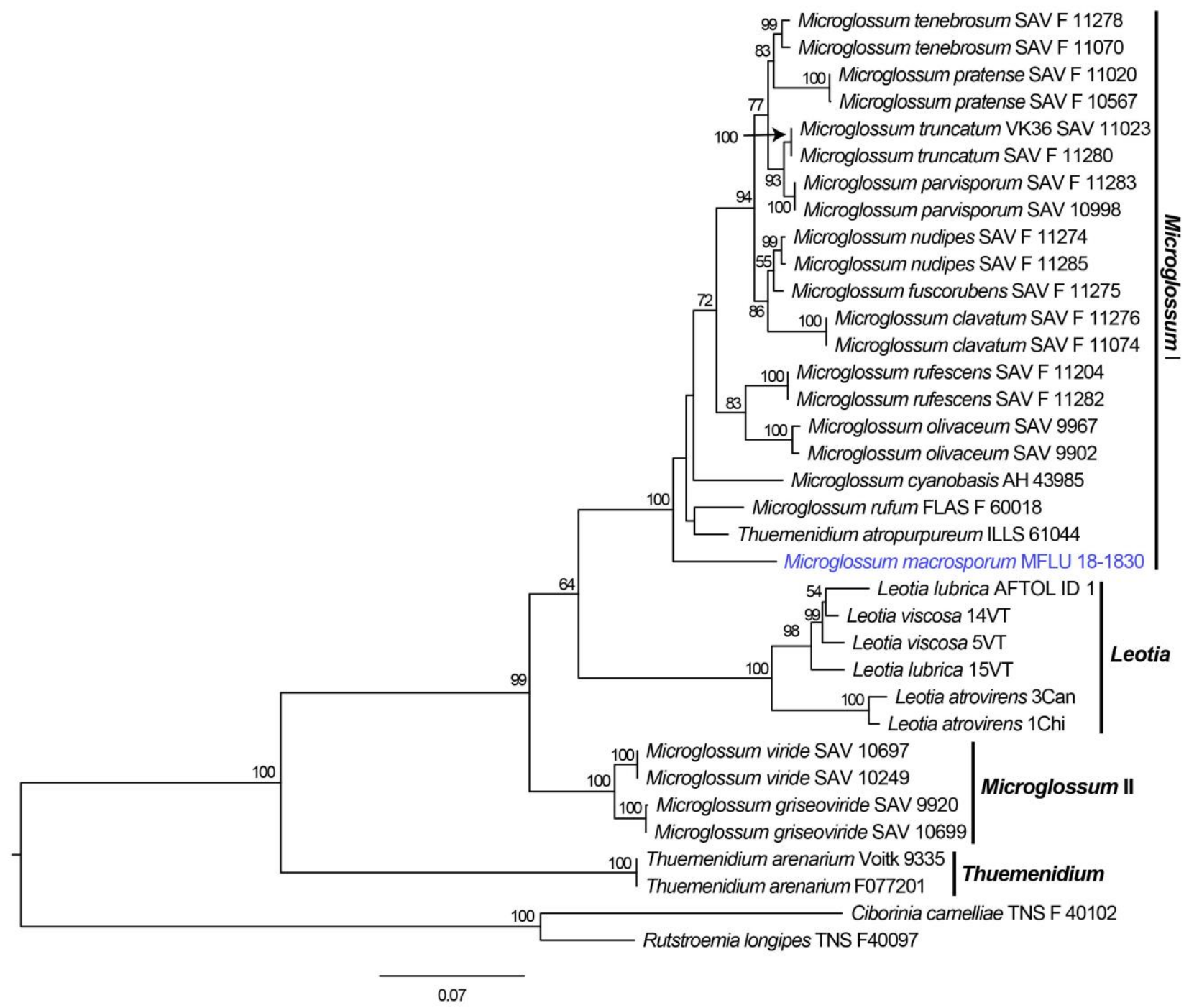

Figure 45 - Phylogram generated from maximum likelihood analysis of sequences of Leotiaceae based on ITS, LSU, RPB2 sequence data. MLBP values $\geq 50 \%$ are given near the nodes. Strain/culture numbers are given after the taxa. The tree is rooted with Ciborinia camelliae (TNS F 40102) and Rutstroemia longipes (TNS F40097). 


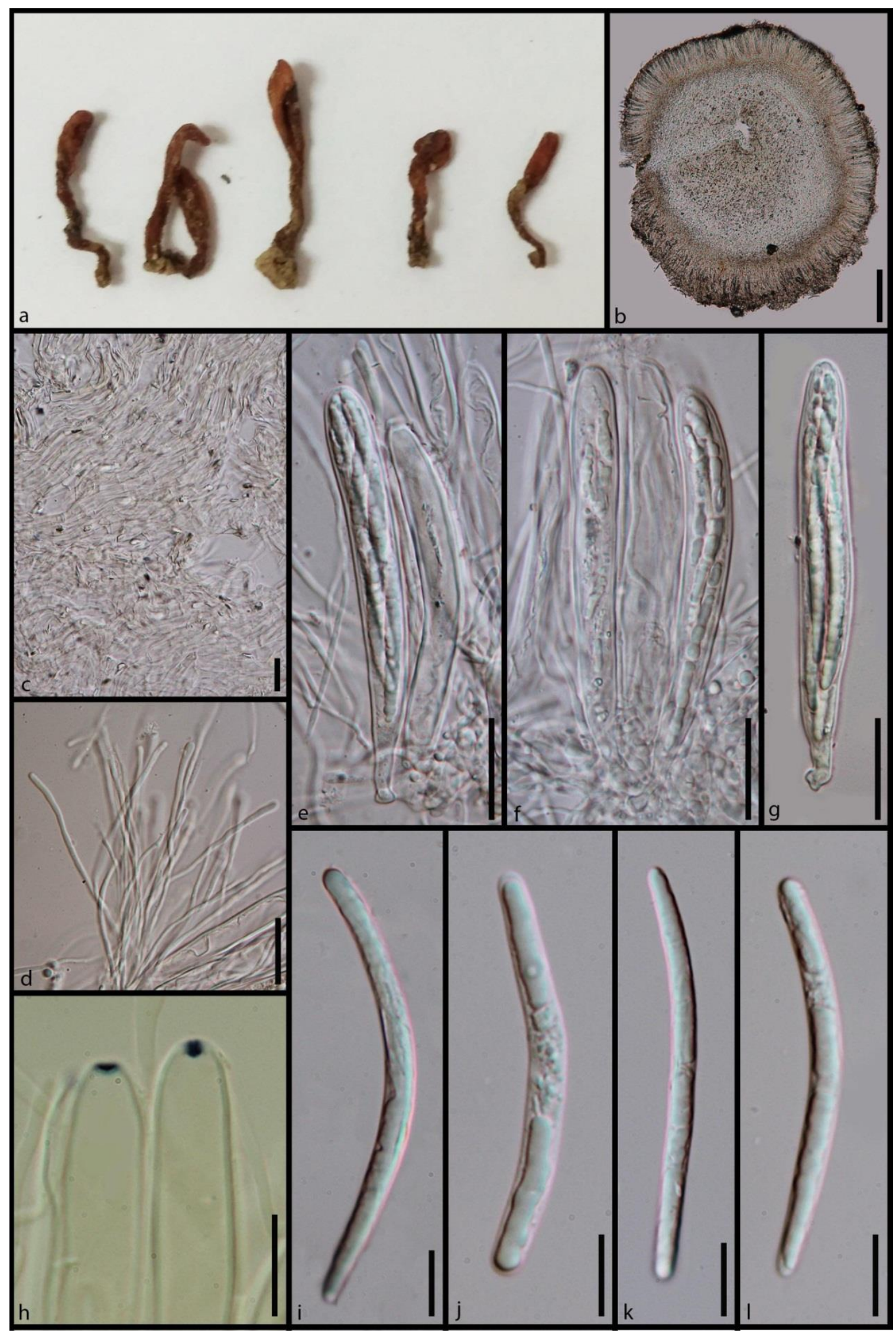

Figure 46 - Morphology of Microglossum macrosporum (MFLU 18-1830 holotype) a Apothecia. b Cross section of an apothecium. c Medullary tissue. d Filiform paraphyses. e-g Cylindric-clavate asci. $\mathrm{h}$ Amyloid ascus apices. i-1 Fusoid ascospores. Scale bars: $\mathrm{b}=100 \mu \mathrm{m}, \mathrm{c}=20 \mu \mathrm{m}, \mathrm{d}=20 \mu \mathrm{m}$, $\mathrm{e}-\mathrm{g}=25 \mu \mathrm{m}, \mathrm{h}=25 \mu \mathrm{m}, \mathrm{i}-\mathrm{l}=10 \mu \mathrm{m}$. 
Tympanidaceae Baral \& L. Quijada

Facesoffungi number: FoF 05920

Taxa are saprobic on dead plant material (Medardi 2007). Ascomata are apothecial. Apothecia are discoid, turbinate or pulvinate receptacle, rarely aggregated into central stroma, often slightly gelatinous, sessile or stipitate and erumpent or superficial. The ectal excipulum is composed of cells of textura globulosa to textura oblita, textura prismatica or textura intricata and medullary excipulum is composed of cells of textura intricata. Paraphyses are filiform, cylindrical to capitate, straight, unbranched, densely septate and rarely curved or helicoid. Asci are 4-8-spored or multi-spored, cylindric-clavate, mostly non-amyloid and arising from croziers. Ascospores are globose, ellipsoid, fusiform or sub-cylindrical, sometimes slightly curved, hyaline, 0-21-septate, guttulate, smooth, hyaline and sometimes producing ascoconidia by budding (Medardi 2007, Jaklitsch et al. 2016, Groves 1954, 1952, 1967, Quijada et al. 2018). Asexual morphs are pycnidial or hyphomycetous. Pycnidia are uni- or multilocular and hyphomycetes are synnematal. Conidiogenesis is phialidic and conidia are hyaline, ellipsoid, filiform, cylindric or allantoid, sometimes curved and 0-3-septate (Medardi 2007, Damm et al. 2010, Groves 1954, 1952, Funk 1979, Quijada et al. 2018).

Notes - The genera of this family were previously assigned to Bulgariaceae, Dermateaceae and Helotiaceae. Jaklitsch et al. (2016) suggested they are phylogenetically close to Phacidiaceae. However, in our phylogenetic analysis this family formed a monophyletic clade within Leotiales. Pärtel (2016) showed the close genetic relationship of Tympanidaceae and Leotiaceae. Therefore, considering our results and previous literature, we include this family under Leotiales.

\section{Cochlearomycetaceae Crous}

Facesoffungi number: FoF 05921

Taxa are saprobic. Sexual morphs are not recorded. Asexual morphs are ceolomycetous or hyphomycetous. Pycnidia are infundibuliform to nidulariaceous, superficial, separate, dark brown to black, sessile, wall composed of cells of textura angularis and textura prismatica. Conidiophores are 1-2-septate, hyaline, sparingly branched and arising from conidiomatal basal wall. Hyphomycetous conidiomata are solitary, erect, dark brown or synnemata dark brown and smooth. Conidiogenesis is phialidic. Conidia are solitary, aseptate, hyaline, smooth, cylindrical and straight with obtuse ends (Crous et al. 2017).

Notes - This family was previously placed in Helotiales. However, our phylogeny showed its close relationship within Leotiales.

\section{LEPTODONTIDIACEAE CLADE}

This clade includes hyphomycetes, which were previously classified within Helotiales. In our analysis, this clade forms a monophyletic clade close to Rhytismatales.

\section{Leptodontidiaceae Hern.-Restr., Crous \& Gené}

Facesoffungi number: FoF 05922

Taxa are saprobic. Sexual morphs are not recorded. Asexual morphs are hyphomycetous. Conidiophores are erect, simple or irregularly branched and macronematous. Conidiogenous cells are polyblastic. Conidia are dry, solitary, unicellular, subcylindrical to narrowly obovate, straight or slightly curved and hyaline with truncate base. The synasexual morph is beauveria-like. Conidiophores are in dense clusters and sometimes reduced to conidiogenous cells. Conidiogenous cells are polyblastic, sympodial, lageniform to subcylindrical, curved and hyaline. Conidia are aseptate, globose to subglobose, with apiculate base, guttulate, hyaline and smooth.

Notes - Hernandez-Restrepo et al. (2017) introduced the family Leptodontidiaceae to accommodate the asexual genus Leptodontidium, with about nine species (Hernandez-Restrepo et al. 2017). 


\section{LICHINODIALES}

This order was introduced by Prieto et al. (2018). Formerly this order included the single family Lichinodiaceae.

\section{Lichinodiaceae M. Prieto, M. Schultz, Olariaga \& Wedin}

Facesoffungi number: FoF 05923

Taxa are lichenized, saprobic, bryosymbiotic, plant pathogenic or lichenicolous. Ascomata are apothecial and characterized by cupulate, turbinate or pulvinate receptacle. The excipulum is pigmented, composed of tightly arranged hyphae or cells of textura intricata, it is not differentiated into ectal excipulum and medullary excipulum or unclear and some taxa lack proper exciple. The hymenium is gelatinous. Paraphyses are cylindrical or filiform, septate, sometimes apically swollen and pigmented. Asci are 8-spored, cylindrical-clavate, sometimes prototunicate, non-amyloid and arising from croziers. Ascospores are simple, hyaline and ellipsoid to pyriform or globose to subglobose (Czarnota \& Hernik 2013, Egertová et al. 2016a, Prieto et al. 2018). Asexual morphs are pycnidial and conidiophores are simple with filiform conidia (Prieto et al. 2018).

Notes - This family formerly included the single genus Lichinodium. Our phylogeny showed that Epiglia, Mniaecia and Mycosymbioces, the genera previously placed in Helotiales genera incertae sedis are genetically related to Lichinodiaceae. Therefore, we include these genera in this family.

\section{Epicladonia-Epithamnolia clade}

Facesoffungi number: FoF 05987

Taxa are saprobic, plant pathogenic or lichenicolous. Sexual morphs are not recorded. Asexual morphs are coelomycetous, pycnidia subglobose to cupuliform, immersed when immature and superficial at maturity. Walls composed of densely interwoven short-celled hyphal tissue or cells of textura angularis, globulosa or textura porrecta. Conidiogenous cells are lining the pycnidial cavity, elongate to elongate-ampulliform or lageniform to narrowly elliptic, slightly tapering towards the apex, sometimes branched and hyaline. Conidiogenesis is phialidic. Conidia are narrowly ellipsoidal to fusiform or cylindrical, apex rounded and the base slightly truncated, thin-walled, hyaline and aseptate (Ihlen \& Wedin 2006, Zhurbenko 2012, Suija et al. 2017, Joshi et al. 2015, 2017).

Notes - Epicladonia is a polyphyletic genus. Some species clade in Leotiomycetes and some are genetically related to Lecanoromycetes (Pino-Bodas et al. 2015, 2017). However, the generic type E. sandstedei belongs to Leotiomycetes. In our analysis Epicladonia and Epithamnoloia formed a separate clade. Taxa of this family are frequently occured on Cladonia and Thamnoloia species (Zhurbenko 2012, Zhurbenko \& Pino-Bodas 2017).

\section{MICRASPIS CLADE}

Micraspis was introduced by Darker (1963). Previously this genus was placed within Phacidiaceae and Tympanidaceae. However, in our analysis Micraspis formed an independent clade close to Leotiales and Phacidiales.

\section{Micraspis clade}

Facesoffungi number: FoF 05924

Taxa are saprobic or plant pathogenic. Ascomata are apothecial, immersed within the substrate, elliptical and opening by a longitudinal slit or irregular split at central area of cover. Ectal excipulum is composed of cells of dark coloured cells of textura angularis and medullary excipulum is composed of light coloured cells of textura angularis. Paraphyses are filiform and often branched at the tip. Asci are 8-spored, cylindric-clavate and non-amyloid. Ascospores are hyaline, elliptical to obovate, 3-septate and forming ascoconidia by budding (Darker 1963). Asexual morphs are pycnidial, opening by a longitudinal fissure, outer wall composed of dark cells of textura angularis and whole cavity of pycnidium lined with short conidiophores arising from 
angularis cells of the inner wall. Conidia are filiform, 1-3-septate and slightly curved (Darker 1963).

Notes - Micraspis was formerly placed in Phacidiaceae based on its morphology (Darker 1963) and later in Tympanidaceae, considering its ascoconidia formation by budding and presence of septate macroconidia (DiCosmo et al. 1984).

\section{MEDEOLARIALES}

The order Medeolariales was introduced by Eriksson (1982). Previously this order included the single family Medeolariaceae and the single genus Medeolaria. In our phylogenetic analysis Medeolariaceae formed a monophyletic clade with Ascodichaenaceae, Dermateaceae and Coleophoma- Parafabraea clade.

\section{Medeolariaceae Korf}

Facesoffungi number: FoF 05925

Taxa are plant pathogenic. Ascomata are apothecial and characterized by irregularly organized, reduced apothecia erumpent in host tissue. The excipulum is reduced or unclear. Paraphyses are filiform, simple, flexuous, septate below and brownish. Asci are 8-spored, cylindric-clavate, non-amyloid, no organized opening and opening by irregularly rupturing. Ascospores are fusiform to naviculate and with a dark outer wall layer with striations (LoBuglio \& Pfister 2010). Asexual morphs are not recorded.

Notes - Medeolariaceae was a phylogenetically unstable family which included a single plant pathogenic genus. These fungus causes stem lesions and gall-like deformations on stems of herbaceous plants, in autumn (Pfister \& LoBuglio 2013).

\section{Ascodichaenaceae D. Hawksw. \& Sherwood}

Facesoffungi number: FoF 05926

Taxa are plant pathogenic. Ascomata are apothecial and characterized by round to elongate hysterioid apothecia opening by a stellate fissure and carbonaceous. The excipulum is reduced or composed of cells of textura angularis to globulosa and it is not differentiated into ectal excipulum and to medullary excipulum or it is unclear. Paraphyses are filiform, simple and slightly apically swollen. Asci are 4-8-spored, broad clavate-cylindric, non-amyloid and opening by a fissure. Ascospores are ellipsoid to oblong, 0-1-septate, hyaline and granulate (Butin 1977, Butin \& Parameswaran 1980). Asexual morphs are pycnidial, hysteriform. Conidiophores are arising from the innermost layer of pycnidial wall and conidiogenesis is phialidic, microconidia simple or septate, spherical to ovate and hyaline. Conidia are ovate to cylindrical and hyaline (Butin 1977, Butin \& Parameswaran 1980).

Notes - Ascodichaena was formerly placed in Rhytismatales or Phacidiales (Jaklitsch et al. 2016). Later, this family was transferred to Helotiales (Wijayawardene et al. 2018). Lantz et al. (2011) showed that Ascodichaena is genetically related to Dermateaceae. In our phylogenetic study Medeolariaceae and Ascodichaenaceae formed a monophyletic clade.

\section{Ascocorticiaceae J. Schröt.}

Facesoffungi number: FoF 05927

Taxa are saprobic or plant pathogenic. Ascomata are apothecial. Apothecia are effuse, irregular in shape, whitish-greyish or ochraceous and pruinose film. The excipulum is strongly reduced. Paraphyses are simple and unbranched. Asci are 4-16-spored, cylindric-clavate, inamyloid and with or without croziers. Ascospores are cylindric-ellipsoid or vermiform, 0-11-septate, hyaline and eguttulate (Jülich \& de Vries 1982, Oberwinkler et al. 1967, Jaklitsch et al. 2016). Asexual morphs are hyphomycetous, conidiophores are brown, hyaline and bristle-like, conidiogenesis is sympodial and conidia are subglobose, hyaline and small and arranged in a spike (Jaklitsch et al. 2016). 
Notes -Ascocorticium, Ascocorticiellum, Ascosorus were classified under Ascocorticiaceae and their phylogenetic position is unresolved, due to lack of sequence data. Ascocorticiaceae taxa are similar to Medeolariaceae by having erumpent apothecia with strongly reduced excipulum, simple, unbranched paraphyses, cylindric-clavate, non-amyloid asci and cylindric-ellipsoid, septate ascospores. Therefore, we placed this family under Medeolariales.

\section{Coleophoma- Parafabraea clade}

Facesoffungi number: FoF 05988

Taxa are saprobic or plant pathogenic. Ascomata are apothecial and characterized by sessile to sub-sessile or short-stalked turbinate apothecia covered by setae-like structures. Setae are rigid, pale brown, septate, cylindrical, straight or slightly curved and slightly enlarged at truncate apex. The excipulum is reduced or composed of cells of textura angularis to globulosa and not differentiated into ectal excipulum and to medullary excipulum or it is unclear. Paraphyses are cylindrical, slender, and wider at base, septate, apex round and hyaline to pale brown. Asci are 8spored, clavate to cylindrical-clavate and short-pedicellate. Ascospores are in-equilateral, fusoid to ellipsoid, ends rounded, straight or slightly curved, aseptate, thin-walled, hyaline and guttulate (Chen et al. 2016, Duan et al. 2007). Asexual morphs are pycnidial or hyphomycetous acervular, subcuticular to epidermal, pale brown, opening by rupture of overlying host tissues and sometimes with hyaline paraphyses. Conidiomatal wall composed of cells of textura angularis. Conidiogenous cells are arising from inner cells of the wall, phialidic, cylindrical, straight to slightly curved, smooth and hyaline. Conidia are elongate ellipsoidal, mostly straight, broadly obtuse at apex, aseptate, hyaline, thick-walled, minutely guttulate and sometimes producing both micro- and macro-conidia (Duan et al. 2007, Crous et al. 2011, 2012, Chen et al. 2016).

Notes - In our phylogenetic study Parafabraea and Coleophoma formed a monophyletic clade sister to Medeolariaceae and Ascodichaenaceae clade.

\section{Dermateaceae Fr.}

Facesoffungi number: FoF 05928

Taxa are saprobic or plant pathogenic. Ascomata are apothecial and characterised by sessile or short-stipitate, cupulate to sub-spherical, urceolate or discoid receptacle. The ectal excipulum is sometimes reduced within host tissue or composed of cells of textura angularis to globulosa, with yellow to brown pigments and medullary excipulum is composed of cells of textura angularis. Paraphyses are filiform, apically slightly swollen, septate and branched. Asci are 4-8-spored, cylindric-clavate, amyloid or non-amyloid and arising from croziers. Ascospores are hyaline, ellipsoid-oblong, aseptate, guttulate and sometimes with a delicate sheath (Petrak 1951, Nauta \& Spooner 1999a, b, c, d, 2000a, b, Svrček 1977a, Ekanayaka et al. 2016). Asexual morphs are pycnidial or acervular. Microconidia are rod-shaped, eguttulate and hyaline and macroconidia are hyaline, multi-guttulate, ellipsoid-oblong to fusoid, aseptate at immature state and becoming muriform at maturity (Ekanayaka et al. 2016, Verkley et al. 2010, Zhu et al. 2012, Romero et al. 2017).

Notes - Dermateaceae is a plant pathogenic family previously classified under Helotiales. However, in our phylogenetic analysis, we observed a close relationship of Dermateaceae with the plant pathogenic family Medeolariaceae. Therefore, we place this family under Medeolariales. Taxa of this family are plant pathogenic which cause stem and fruit rots on vascular plants (Lin et al. 2018, Cameldi et al. 2017, Michalecka et al. 2016, Pešicová et al. 2017, Yuan et al. 2016, Yuan \& Verkley 2015, Chen et al. 2016, Romero et al. 2017).

Neofabraea brunneipila Ekanayaka \& K.D. Hyde, sp. nov.

Index Fungorum number: IF556296; Facesoffungi number: FoF 05929; Fig. 48.

Etymology - refers to dark brown disc

Holotype - MFLU 15-0231 
Saprobic on dead stems. Sexual morph: $115-120 \times 283-287 \mu \mathrm{m}(\bar{x}=117.8 \times 285.9 \mu \mathrm{m}, \mathrm{n}$ =10). Apothecia arising singly or in small groups, sessile, erumpent from the substrate, cupulate. Receptacle convex, disc and the margins are dark brown when fresh. Excipulum 38-42 $\mu \mathrm{m}$ wide $(\bar{x}$ $=40 \mu \mathrm{m}, \mathrm{n}=10$ ), with few cell layers, ectal excipulum comprising light brown, thick-walled cells of textura angularis. Medullary excipulum comprising with granulate, hyaline, thin walled cells of textura intricata, ectal excipulum and medullary excipulum are not clearly distinguishable. Hymenium hyaline. Paraphyses $2.2-2.6 \mu \mathrm{m}$ wide $(\bar{x}=2.4 \mu \mathrm{m}, \mathrm{n}=10)$, numerous, filiform, obtuse. Asci 75-80 × 6-7 $\mu \mathrm{m}(\bar{x}=78.9 \times 6.6 \mu \mathrm{m}, \mathrm{n}=30), 8$-spored, short-pedicellate, unitunicate, cylindric-clavate, rounded at the apex, amyloid ring present at the ascus apex, croziers present at the base of asci. Ascospores $12-16 \times 3-7 \mu \mathrm{m}(\bar{x}=14.6 \times 5.9 \mu \mathrm{m}, \mathrm{n}=40)$, partially biseriate, ovoid, apices are slightly pointed, hyaline, non-septate, smooth-walled, guttulate. Asexual morph: Undetermined.

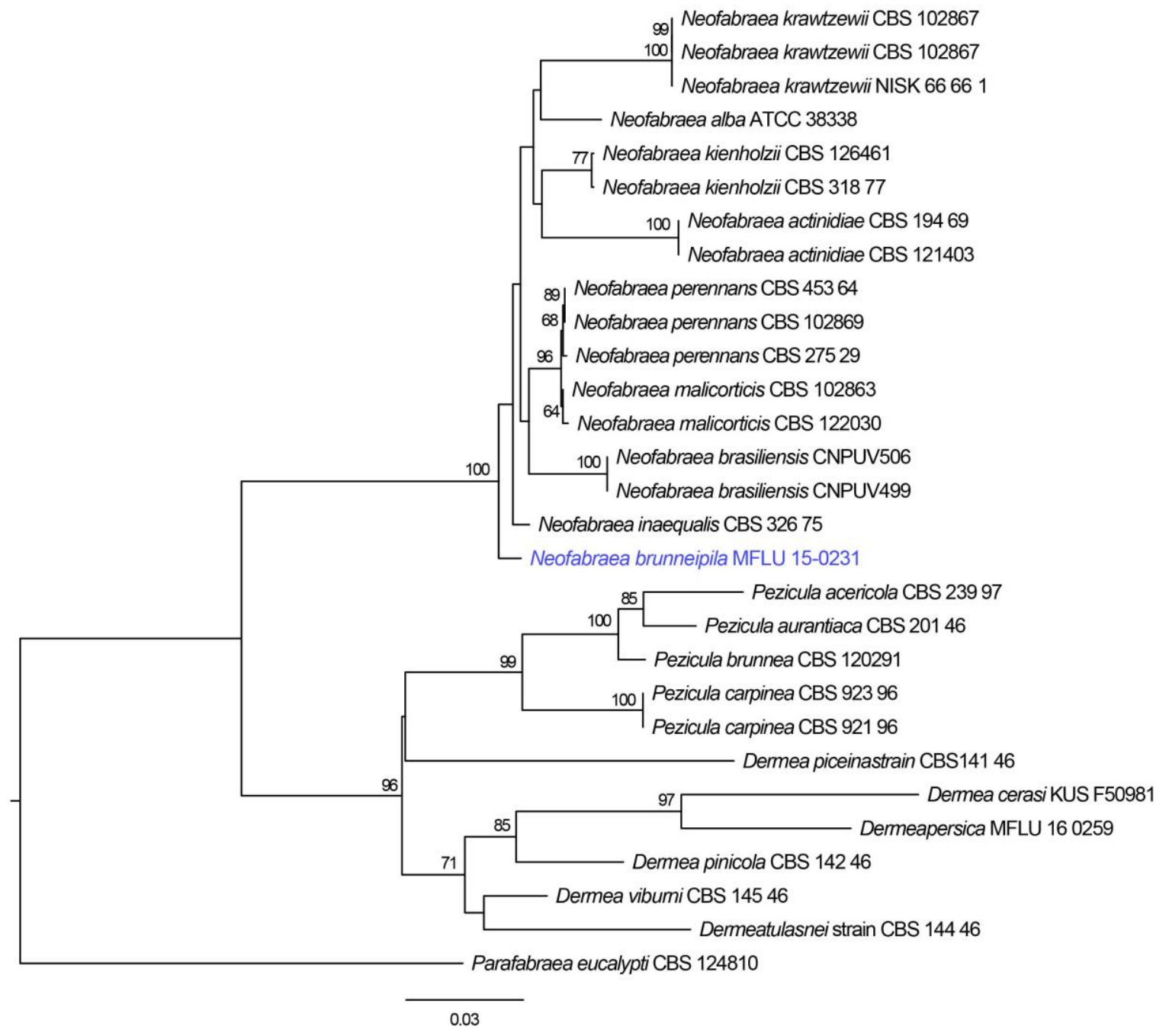

Figure 47 - Phylogram generated from maximum likelihood analysis of sequences of Dermateaceae based on ITS, LSU, RPB2 sequence data. MLBP values $\geq 50 \%$ are given near the nodes. Strain/culture numbers are given after the taxa. The tree is rooted with Parafabraea eucalypti (CBS 124810).

Material examined - Italy, Forlì-Cesena Province [FC], Strada San Zeno - Galeata, on dead aerial branch of Spartium Junceum, 13 November 2014, Erio Camporesi, IT2238 (MFLU 15-0231).

GenBank accessions - LSU- MK592004, ITS- MK584984, SSU- MK585060

Notes - Our strain IT2238 from Italy grouped in the basal position of Neofabreae clade with strong statistical support of $100 \%$ (Fig. 47). The ITS data of our collection is similar to that of 
Neofabraea inaequalis (CBS 326.75) (546/548-99\% with no gaps), $N$. perennans (CBS 453.64) (542/548-99\% with no gaps) and $N$. kienholzii (CBS 318.77) (540/545-99\% with 1 gap). The LSU data of our species is similar to that of $N$. brasiliensis (CNPUV499) (877/885-99\% with 5 gaps), $N$. kienholzii (CBS 126461) (876/885-99\% with 5 gaps) and $N$. malicorticis (AFTOL-ID 149) (874/882(99\% with 5 gaps).

Neofabraea brunneipila is characterized by cupulate erumpent apothecia, numerous filiform paraphyses, short-pedicellate, unitunicate asci and ovoid ascospores with slightly pointed apices. Neofabraea brunneipila is phylogenetically close to $N$. inaequalis. However, we were unable to compare the asexual morph characters of $N$. inaequalis with our strain, as the ascospores of our strain failed in germination. Neofabraea brunneipila is distinct from other species of Neofabraea by having immersed apothecia, larger, amyloid asci and ascospores with pointed apices (Verkley 1999, Cheewangkoon et al. 2009).

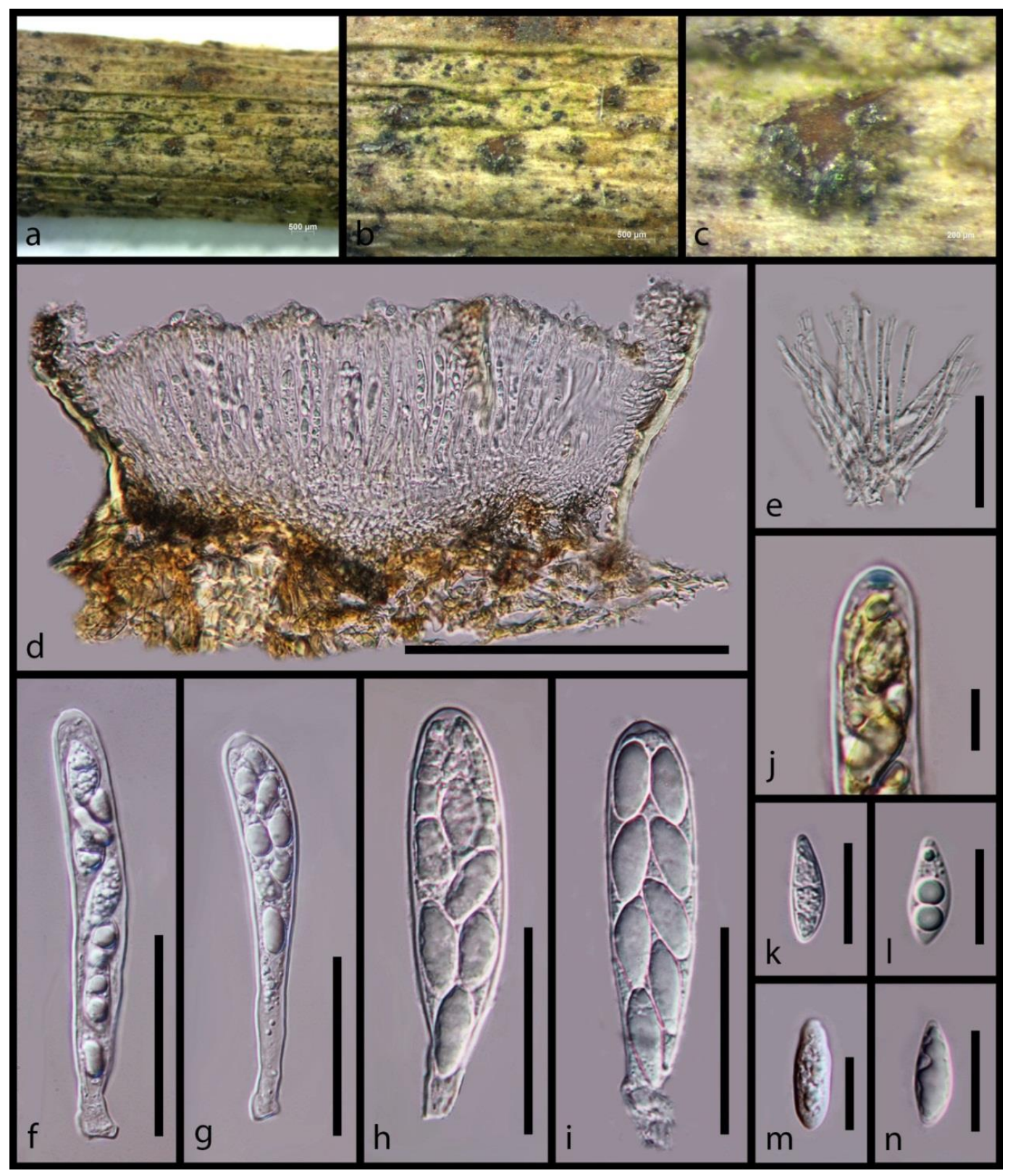

Figure 48 - Morphology of Neofabraea brunneipila (MFLU 15-0231 holotype) a Substrate. b Apothecia on wood. c Apothecium on wood. d Cross section of an apothecium. e Septate paraphyses. $\mathrm{f}-\mathrm{i}$ Cylindric asci. $\mathrm{j}$ Amyloid apex of asci in Melzer's reagent. $\mathrm{k}-\mathrm{n}$ Fusiform ascospores. Scale bars: $\mathrm{a}=500 \mu \mathrm{m}, \mathrm{b}=500 \mu \mathrm{m}, \mathrm{c}=200 \mu \mathrm{m}, \mathrm{d}=200 \mu \mathrm{m}, \mathrm{e}=25 \mu \mathrm{m}, \mathrm{f}-\mathrm{i}=30 \mu \mathrm{m}$, $\mathrm{j}-\mathrm{n}=10 \mu \mathrm{m}$. 


\section{NEOCRINULACEAE CLADE}

The family Neocrinulaceae was introduced by Crous et al. (2017). Formerly this family was placed under Helotiales. In our phylogenetic analysis this family formed an independent clade at order-level, but without a statistical support.

\section{Neocrinulaceae Crous}

Facesoffungi number: FoF 05930

Taxa are saprobic. Sexual morphs are not recorded. Asexual morphs are hyphomycetous, sporodochial or synnematous. Conidiophores are hyaline to brown, smooth to verruculose, subcylindrical, branched and septate. Conidiogenesis is phialidic and with periclinal thickening. Conidia are solitary, hyaline, smooth, aseptate and fusoid-ellipsoid (Crous et al. 2017).

Notes - This family includes the single genus Neocrinula. In our phylogenetic analysis this family clustered close to Leptodontidiaceae.

\section{PHACIDIALES}

The order Phacidiales was introduced by Höhnel (1917). Previously this order included three families, Phacidiaceae, Tympanidaceae and Helicogoniaceae. In our phylogenetic analysis, Phacidiaceae formed a monophyletic well-supported clade sister to Thelebolales-Leotiales clade. Therefore, considering previous literature (Johnston et al. 2014, Pärtel 2016) and our phylogenetic results we include only Phacidiaceae within Phacidiales.

\section{Phacidiaceae Fr.}

Facesoffungi number: FoF 05931

Taxa are saprobic or plant pathogenic. Ascomata are apothecial and characterized by discoid to cupulate receptacle. Apothecia are initially immersed and opening usually by splitting of upper layer into teeth or lobes with adhering host tissue. The ectal excipulum is composed of cells of textura globulosa to angularis and medullary excipulum is unclear or very thin and composed of smooth-walled, hyaline hyphae invested in mucilage. Paraphyses are filiform, cylindrical or lanceolate, sometimes apically curled, rarely branched, anastomosing and invested in mucilage or not. Asci are 4-8-spored, cylindric-clavate, amyloid or non-amyloid and arising from croziers. Ascospores are ellipsoid, fusoid or cylindric-clavate, hyaline, aseptate, guttulate, straight or curved and with or without germ slit (Xiao et al. 2005, Bellemère 1968, Crous et al. 2014, DiCosmo et al. 1984, Egger 1968, Lantz et al. 2011, Verkley 1992). Asexual morphs are pycnidial, uni- or multilocular, single to aggregated, with one to several ostioles. Walls of conidiomata are composed of textura angularis to textura globulosa. Conidiogenous cells are arising from inner layer of conidioma. Conidiogenesis is phialidic. Conidia are subcylindrical, ellipsoid-oblong or subreniform, aseptate and sometimes with mucoid apical appendage (Bellemère 1968, Crous et al. 2014, DiCosmo et al. 1984, Egger 1968, Lantz et al. 2011, Verkley 1992, Tanney \& Seifert 2018).

Notes - Bulgariaceae was previously classified within Helotiales. Later, considering its genetic and morphological relationships Bulgariaceae was synonymized under Phacidiaceae (Crous et al. 2014).

Bacilliformis Ekanayaka \& K.D. Hyde, gen. nov.

Index Fungorum number: IF556297; Facesoffungi number: FoF 05932; Fig. 50

Etymology - refers to the baciliform conidia.

Saprobic on dead stem. Sexual morph: Undetermined. Asexual morph: Conidiomata pycnidial, single or in groups, dark brown to black, immersed, multiloculate, opening by a single ostiole. Wall composed of dark brown cells of textura angularis. Conidiogenous cells hyaline, arising from the inner cell wall of peridium, broad base, pointed tips. Conidia short cylindrical or baciliform, hyaline.

\section{Type species: Bacilliformis hyalinus}




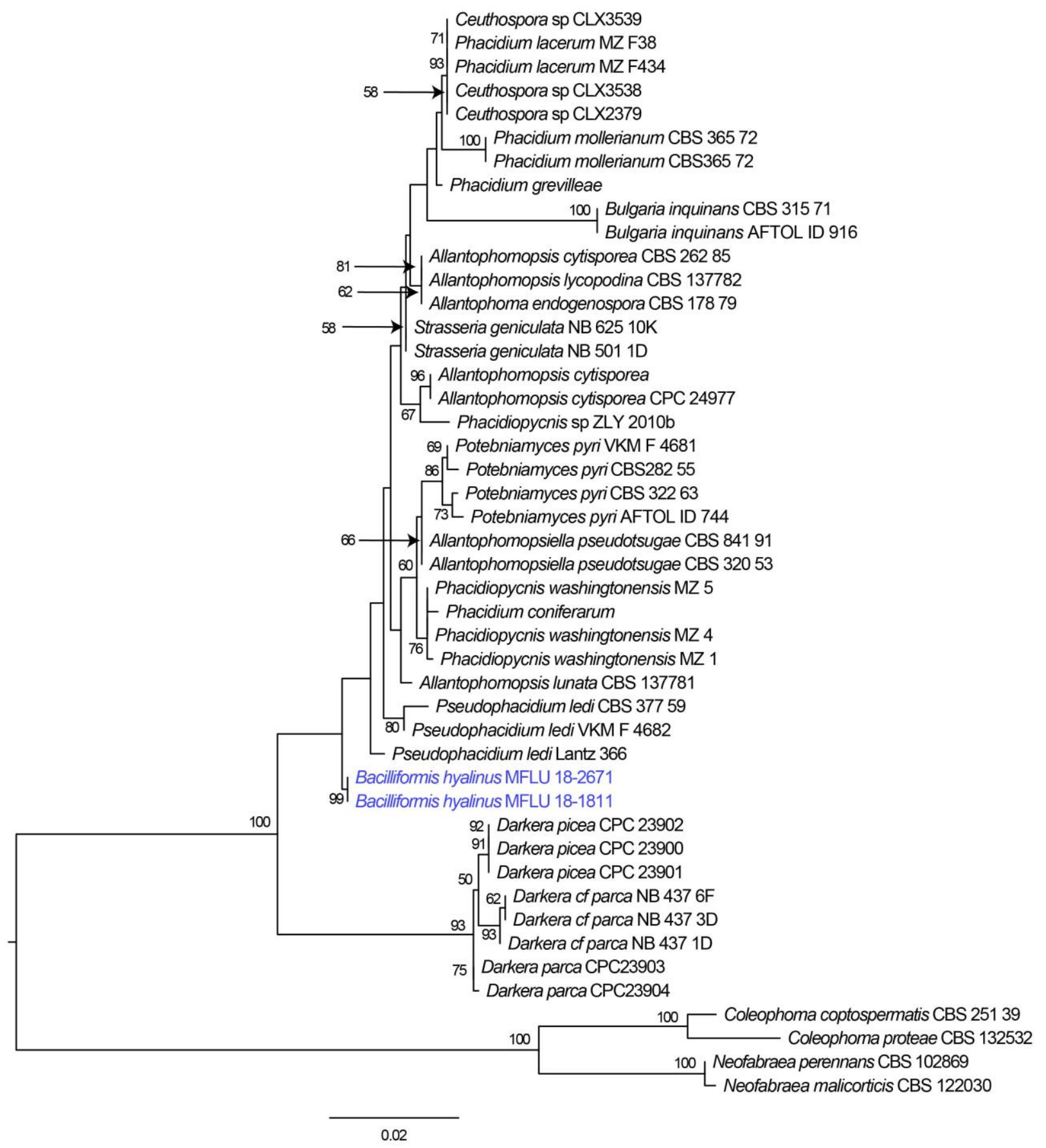

Figure 49 - Phylogram generated from maximum likelihood analysis of sequences of Phacidiaceae based on ITS, LSU sequence data. MLBP values $\geq 50 \%$ are given near the nodes. Strain/culture numbers are given after the taxa. The tree is rooted with Coleophoma proteae (CBS 132532), Coleophoma coptospermatis (CBS 251 39), Neofabraea perennans (CBS 102869) and Neofabraea malicorticis (CBS 122030).

Bacilliformis hyalinus Ekanayaka \& K.D. Hyde, sp. nov.

Index Fungorum number: IF556298; Facesoffungi number: FoF 05933; Fig. 50.

Etymology - refers to the hyaline conidia

Holotype - MFLU 18-2671

Weak pathogenic on dead stem. Sexual morph: Undetermined. Asexual morph: Conidiomata pycnidial 1-2 mm high, 0.8-1.2 mm wide, single or in groups, dark brown to black, immersed, multiloculate, opening by a single ostiole. Wall composed of dark brown cells of textura 
angularis. Conidiogenous cells hyaline, arising from the inner cell wall of peridium, flask-shaped, broad base, pointed tips. Conidia 3.5-5.5 × 1.5-2.5 $\mu \mathrm{m}$, short cylindrical or baciliform, hyaline.

Material examined - Russia, Rostov region, Krasnosulinsky District, Gornensky Zakaznik (protected landscape), trees on the riverside of Kundryuchya River, weak parasitic on dying twigs of Salix alba L. (Salicaceae), 28 June 2015, Timur S. Bulgakov, T847 (MFLU 18-2671); Russia, Arkhangelsk region, Akhangelsk City, Maimaksansky City District, floodplain bushes, saprobic or weak parasitic on dying twigs of Salix myrsinifolia Salisb. (Salicaceae), 16 May 2016, Gennady V. Okatov, T-553 (MFLU 18-1811).

GenBank accessions - MFLU 18-2671: LSU- MK591952, ITS- MK585001, RPB2MK341543; MFLU 18-1811: LSU- MK591951, ITS- MK584997, RPB2- MK310263

Notes - Our collections from Russia formed an independent clade within Phacidiales (Fig. 49), with strong statistical support (MLPB- 99\%). However, its sister relationship with other Phacidiales taxa is poorly supported (MLPB- $48 \%$, not shown as the value is $\leq 50 \%$ ). The ITS data of our collection is similar to that of Phacidium lacerum (NW-FVA2688) (473/478-99\%), but differ by 5 base pairs with no gaps and to Allantophomopsiella pseudotsugae (CBS 321.53) (472/480-98\%), but differ by 8 base pairs with 2 gaps. The LSU data of our collection shows similarity to that of Phacidium lauri (CBS 308.68) (882/892-99\%), but differ by 10 base pairs with 2 gaps, Allantophomopsiella pseudotsugae (CBS 437.71) (882/892-99\%), but differ by 10 base pairs with 3 gap and Phacidiopycnis washingtonensis (MZ-1-Posth) (882/892-99\%), but differ by 10 base pairs with 3 gaps.

Therefore, considering the phylogenetic placement of our collection within Phacidiales and the guidelines to introduce new taxa provided by Jeewon \& Hyde (2016), we introduce the new genus Bacilliformis here.

Bacilliformis is similar to Allantophomopsiella, but is distinct in lacking mucoid apical appendages. Morphology of Bacilliformis is also close to Apostrasseria and Allantophomopsis, but differs in lacking percurrent proliferation and in having short cylindrical or bacilliform conidia (Crous et al. 2014).

\section{RHYTISMATALES}

This order was introduced by Hawksworth \& Eriksson (1986) to accommodate the single family Rhytismataceae. In our analysis Rhytismataceae together with Pezizellaceae and Calloriaceae formed a monophyletic clade close to the Hyphodiscus-Chalara clade and therefore, we include them under Rhytismatales.

\section{Calloriaceae Marchand}

Facesoffungi number: FoF 05934

Taxa are mostly saprobic in terrestrial and marine habitats and some are endophytes in plant roots (Ashrafi et al. 2018, Baral \& Rämä 2015). Ascomata are apothecial. Apothecia are cupulate or rounded to elongated, sessile, erumpent or seemingly superficial, some are closed when immature and opening by slit-like or by lobes. The ectal excipulum is composed of cells of hyaline textura prismatica or textura angularis to globulosa and medullary excipulum is composed of cells of textura prismatica to porrecta. Paraphyses are filiform or lanceolate, apically slightly swollen, straight or flexuous and sometimes guttulate. Asci are mostly 8-spored, non-amyloid or amyloid and sometimes arising from croziers. Ascospores are ellipsoid to fusoid, aseptate or 1-3-sepatate and guttulate (Svrcek 1977b, 1976, 1982, Nannfeldt 1984, Baral \& Räma 2015, Baral \& Haelewaters 2015, Haelewaters et al. 2018, Ashrafi et al. (2018). Asexual morphs are hyphomycetous and sporodochial. Conidiogenesis is phialidic. Conidia are aseptate and globose to ellipsoid or fusoid (Jaklitsch et al. 2016).

Notes - In our phylogeny the genera Stamnaria, Belonioscyphella, Roseodiscus, Tetracladium, Cistella, Urceolella, Mycoarthris, Rodwayella, Psilachnum and Rommelaarsia, which were previously, classified under the other helotilian families, nested within Calloriaceae. Jaklitsch et al. (2016) suggested the genetic similarity of Tetracladium with Calloriaaceae. 


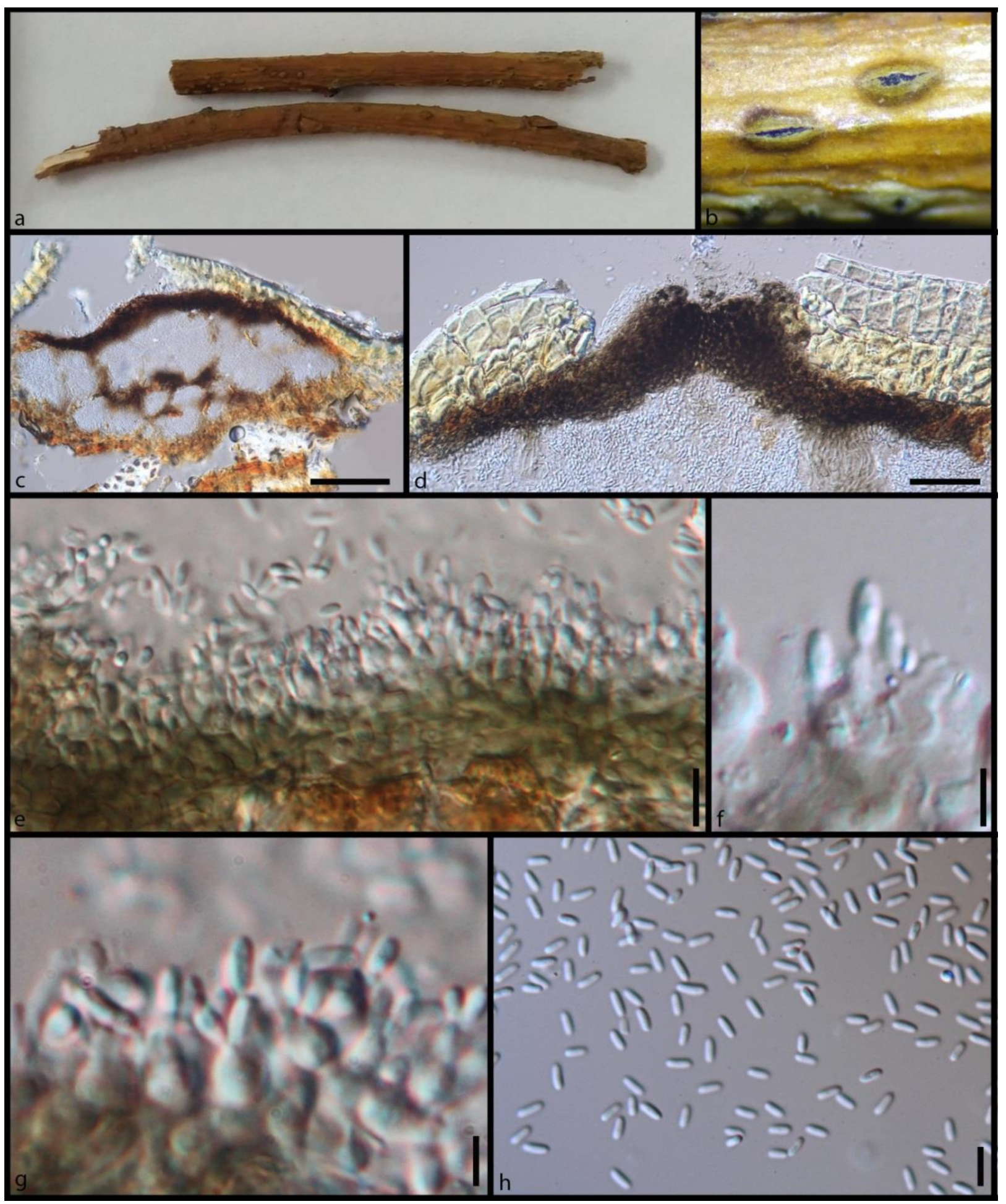

Figure 50 - Morphology of Bacilliformis hyalinus (MFLU 18-2671 holotype) a Substrate. b Conidiomata on substrate. c Cross section of conidioma. d Close up of cross section of conidioma at ostiole. e-g Different stages of conidiogenesis. h Conidia of different stages. Scale bars: $c=100$ $\mu \mathrm{m}, \mathrm{d}=50, \mathrm{e}=15 \mu \mathrm{m}, \mathrm{f}, \mathrm{g}=5, \mathrm{~h}=10$.

Baral \& Haelewaters (2015) showed the placement of Rommelaarsia, Psilachnum and Cistella within Calloriaceae. Close phylogenetic relationship of Rodwayella, Cistella, Urceolella, Tetracladium, Belonioscyphella, Roseodiscus, Psilachnum and Polyphilus within Calloriaceae was reported by Ashrafi et al. (2018). Bergero et al. (2003) showed close phylogenetic relationship between Mycoarthris and Cistella. Therefore, considering the results of our phylogenetic study and previous literature, we include these genera in the family Calloriaceae. 


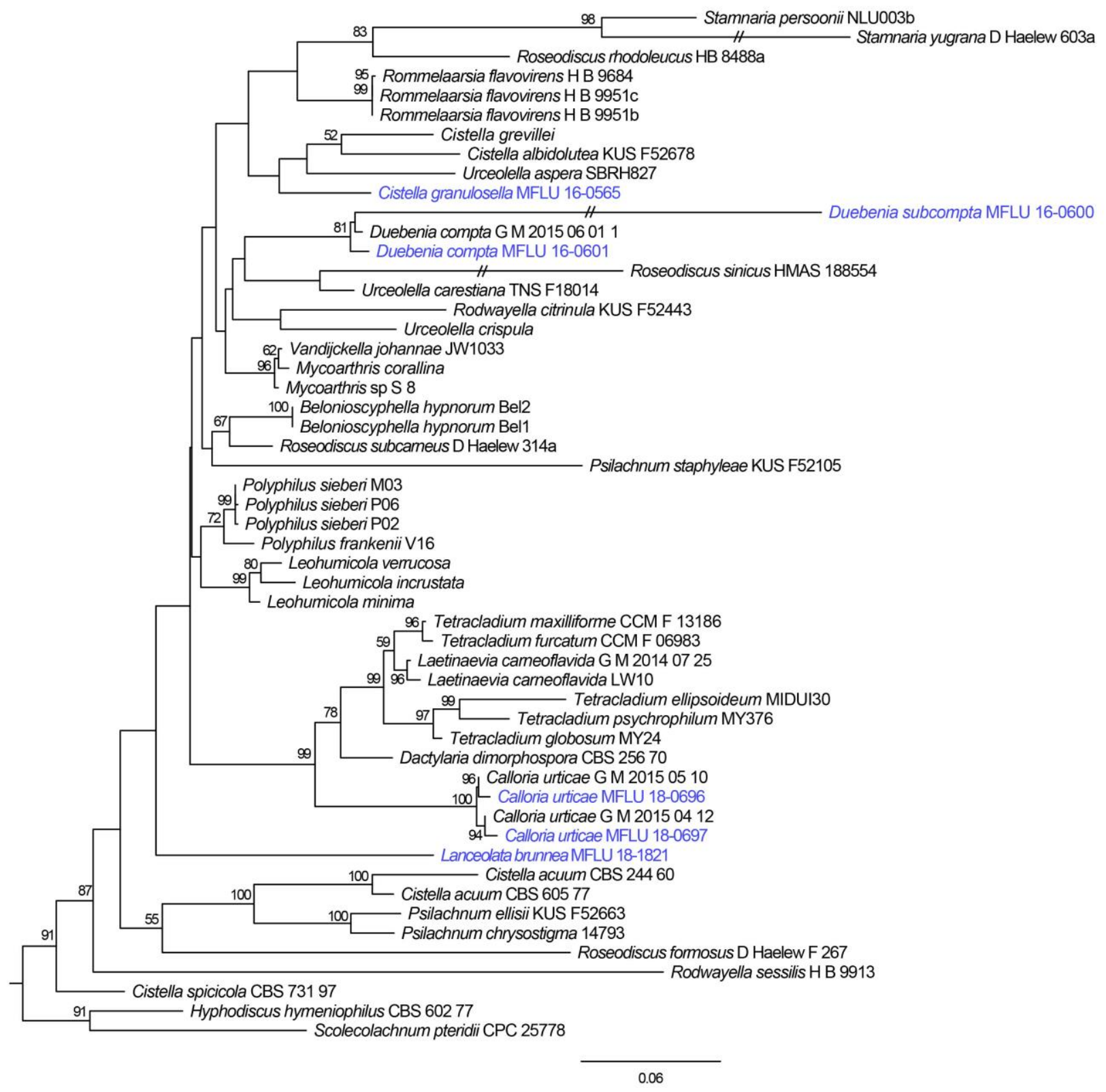

Figure 51 - Phylogram generated from maximum likelihood analysis of sequences of Calloriaceae based on ITS and LSU sequence data. MLBP values $\geq 50 \%$ are given near the nodes. Strain/culture numbers are given after the taxa. The tree is rooted with Hyphodiscus hymeniophilus (TNS F31801) and Scolecolachnum pteridii (CPC 25778).

Calloria urticae (Pers.) J. Schröt. ex Rehm

Facesoffungi number: FoF 05935; Fig. 52

Saprobic on dead stems. Sexual morph: Apothecia 300-350 $\times 100-150 \mu \mathrm{m}$, arising singly or in groups, sessile, erumpent. Receptacle cupulate, reddish orange. Disc concave, reddish orange. Ectal excipulum 15-20 $\mu \mathrm{m}(\bar{x}=17 \mu \mathrm{m}, \mathrm{n}=10)$ in upper flanks, composed of thin-walled, light brown to hyaline cells of textura prismatica to angularis. Medullary excipulum $8-12 \mu \mathrm{m}(\bar{x}=10$ $\mu \mathrm{m}, \mathrm{n}=10$ ) in upper flanks, composed of thin-walled, hyaline cells of textura oblita. Hymenium hyaline. Paraphyses $2-3.5 \mu \mathrm{m}$ wide $(\bar{x}=2.8 \mu \mathrm{m}, \mathrm{n}=20)$, numerous, filiform, obtuse, slightly swollen and curved at the apex, aseptate, smooth. Asci 55-75 $\times 6.5-8.5 \mu \mathrm{m}(\bar{x}=61 \times 7 \mu \mathrm{m}, \mathrm{n}=$ 30), 8-spored, unitunicate, cylindric-clavate, rounded apex, amyloid, stipitate base, croziers absent. Ascospores 5.5-7 × 3-4 $\mathrm{m}(\bar{x}=6.6 \times 3.6 \mu \mathrm{m}, \mathrm{n}=40), 1-2$-seriate, ellipsoid, aseptate, hyaline. Asexual morph: Undetermined. 
Material examined - UK, West Sussex, Singleton, on unidentified stem, 5 April 2017, E. B. G. Jones, GJ346a (MFLU 18-0696), GJ346b (MFLU 18-0697).

GenBank accessions - MFLU 18-0696: LSU- MK591968, ITS- MK584941, SSUMK585029, TEF- MK637045, RPB2- MK373057; MFLU 18-0697: LSU- MK591969, ITSMK584942, SSU- MK585030, TEF- MK637046, RPB2- MK373058

Notes - Our collection of Calloria urticae from UK grouped with the European collections of C. urticae (G.M. 2015-05-10 and G.M. 2015-04-12) (Fig. 51) with high statistical support. The ITS regions of our collections are identical with C. urticae (G.M. 2015-05-10) and 99\% similar to that of C. urticae (G.M. 2015-04-12) (549/550-99\% with no gaps). Calloria urticae is characterized by sessile erumpent, reddish orange apothecia, filiform paraphyses with obtuse, slightly swollen and curved apices, cylindric-clavate, amyloid asci and ellipsoid, aseptate ascospores. We identify our collection based on genetic similarities.

Lanceolata Ekanayaka \& K.D. Hyde, gen. nov.

Index Fungorum number: IF556300; Facesoffungi number: FoF 05936

Etymology - refers to the lanceolate paraphyses.

Saprobic on dead stems. Sexual morph: Apothecia arising singly, sessile, superficial. Receptacle cupulate, brown or orange with glassy appearance. Disc concave, brown. Ectal excipulum composed of thin-walled, light brown to hyaline cells of textura angularis. Medullary excipulum composed of thin-walled, hyaline cells of textura prismatica. Hymenium hyaline. Paraphyses numerous, filiform, lanceolate, conical at the apex, aseptate, smooth. Asci arising from croziers, 8-spored, unitunicate, cylindric-clavate, conical to rounded apex, amyloid, sub-stipitate base, absent at the base of asci. Ascospores fusoid, aseptate, hyaline, guttulate. Asexual morph: Undetermined.

Type species: Lanceolata brunnea

Lanceolata brunnea Ekanayaka \& K.D. Hyde, sp. nov.

Index Fungorum number: IF556299; Facesoffungi number: FoF 05937; Fig. 53.

Etymology - refers to the brownish apothecia

Holotype - MFLU 18-1821

Saprobic on dead stems. Sexual morph: Apothecia 400-500 × 100-150 $\mu \mathrm{m}$, arising singly, sessile, superficial. Receptacle cupulate, brown or orange with glassy appearance. Disc concave, brown. Ectal excipulum 15-18 $\mu \mathrm{m}(\bar{x}=17 \mu \mathrm{m}, \mathrm{n}=10)$ in lower flanks, composed of thin-walled, light brown to hyaline cells of textura angularis. Medullary excipulum 9-15 $\mu \mathrm{m}(\bar{x}=13 \mu \mathrm{m}, \mathrm{n}=$ 10) in lower flanks, composed of, thin-walled, hyaline cells of textura prismatica. Hymenium hyaline. Paraphyses $2.5-3.5 \mu \mathrm{m}$ wide $(\bar{x}=3.3 \mu \mathrm{m}, \mathrm{n}=20)$, numerous, filiform, lanceolate, conical at the apex, aseptate, smooth. Asci 35-50 × 6-9 $\mu \mathrm{m}(\bar{x}=43 \times 8.4 \mu \mathrm{m}, \mathrm{n}=30)$, arising from croziers, 8-spored, unitunicate, cylindric-clavate, conical to rounded apex, amyloid, sub-stipitate base, arising from croziers. Ascospores $12-20 \times 3-4 \mu \mathrm{m}(\bar{x}=17 \times 3.6 \mu \mathrm{m}, \mathrm{n}=40), 1-2$-seriate, fusoid, aseptate, hyaline, guttulate. Asexual morph: Undetermined.

Material examined - UK, Hampshire, New Forest, Exbury Gardens, 19 April 2016, E.B.G Jones, GJ270 (MFLU 18-1821).

GenBank accessions - LSU- MK591967, ITS- MK584940, SSU- MK585028, TEFMK637044, RPB2- MK373056

Notes - Our collection formed an independent clade within Calloriaceae close to Calloria urticae clade (Fig. 51). However, the statistical support for this clade is low.

The LSU region of our collection is similar to that of Polyphilus sieberi (P02) (861/888-97\% with 4 gaps) and Polyphilus frankenii (REF050) (849/875-97\% with 2 gaps). The ITS region shows 90\% similarity to that of Hyphodiscus brachyconius (CBS 700.73) (376/423-89\%), but differ by 47 base pairs with 7 gaps and Hyphodiscus brevicollaris (CBS 126.74) (366/410-89\%), but differ by 44 base pairs with 11 gaps. The single gene analyses of LSU and ITS from Calloriaceae and some 
selected helotilian taxa shows its placement within Calloriaceae (data not shown). Therefore, we introduce this collection as a new genus in Calloriaceae.

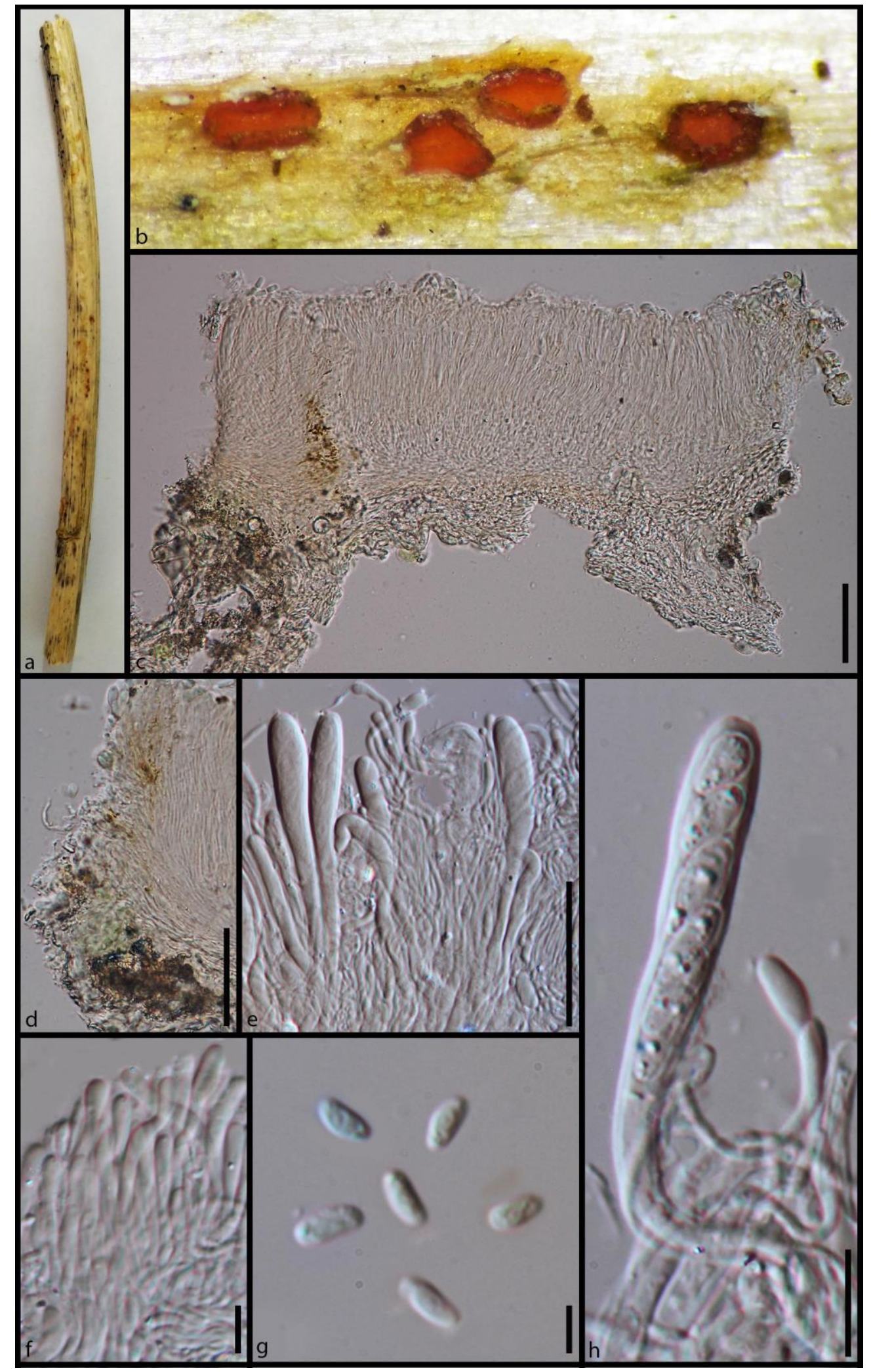

Figure 52 - Morphology of Calloria urticae (MFLU 18-0696) a Substrate. b Apothecia on stem. c Cross section of an apothecium. d Close up of the cross section of apothecium at margins. e Asci and paraphyses. f Filiform paraphyses. g Ellipsoid ascospores. h Cylindric-clavate ascus. Scale bars: $\mathrm{c}, \mathrm{d}=40 \mu \mathrm{m}, \mathrm{e}=35 \mu \mathrm{m}, \mathrm{f}, \mathrm{g}=5 \mu \mathrm{m}, \mathrm{h}=10 \mu \mathrm{m}$. 
Lanceolata is similar to other taxa within the family Calloriaceae by having brown to orange cupulate apothecia, amyloid asci arising from croziers, ellipsoid to fusoid ascospores. However, it differs from Calloria, Stamnaria, Roseodiscus and Belonioscyphella by having lanceolate paraphyses and from Psilachnum, Cistella, Rommelaarsia and Urceolella by not having hairs on the apothecia (Svrcek 1977b, 1976, 1982, Nannfeldt 1984, Zheng \& Zhuang 2013, Baral \& Rama 2015, Baral \& Haelewaters 2015, Egertová et al. 2016b, Quijada et al. 2017).

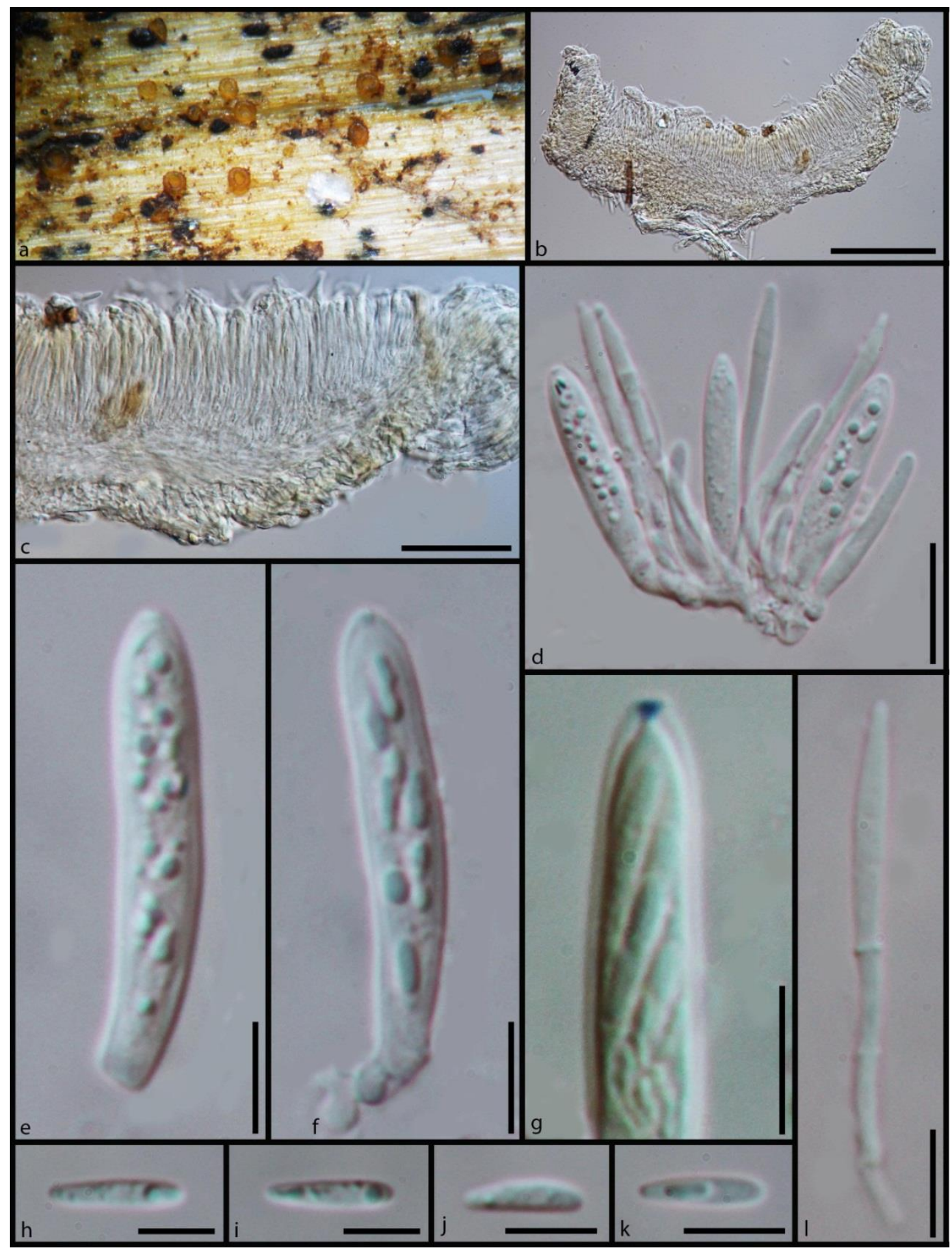

Figure 53 - Morphology of Lanceolata brunnea (MFLU 18-1821 holotype) a Apothecia on wood. b Cross section of an apothecium. c Close up of the cross section of apothecium at margins. $d$ Asci and paraphyses. e-f Cylindric-clavate asci. g Amyloid ascus apex in Melzer's reagent. $\mathrm{h}-\mathrm{k}$ Fusoid ascospores. 1 Lanceolate paraphyses. Scale bars: $b=100 \mu \mathrm{m}, \mathrm{c}=30 \mu \mathrm{m}, \mathrm{d}=20 \mu \mathrm{m}, \mathrm{e}-1=10 \mu \mathrm{m}$. 
Cistella granulosella (P. Karst.) Nannf.

Facesoffungi number: FoF 05938; Fig. 54

Saprobic on dead stems. Sexual morph: Apothecia 130-180 $\mu \mathrm{m}$ wide, arising singly or in small groups, sessile, erumpent from the substrate, brownish white when fresh. Receptacle cupulate to urceolate. Disc concave, disc and the margins are brownish white when fresh. Hairs $25-32 \times$ 3.5-5 $\mu \mathrm{m}(\bar{x}=30.3 \times 4 \mu \mathrm{m}, \mathrm{n}=30)$, cylindric, clavate, 1-2-septate, hyaline, walls usually thin, apices slightly swollen and finely granulate. Ectal excipulum $18-25 \mu \mathrm{m}(\bar{x}=21.8 \mu \mathrm{m}, \mathrm{n}=10)$ in margins and upper flanks, 3-4 cells deep, cell walls are thick, brown cells of textura globulosa to angularis. Medullary excipulum 12-22 $\mu \mathrm{m}(\bar{x}=16.3 \mu \mathrm{m}, \mathrm{n}=10)$ in upper flanks, composed of narrow, long, thin-walled, hyaline cells of textura epidomoidea. Hymenium hyaline. Paraphyses $1.2-1.8 \mu \mathrm{m}$ wide $(\bar{x}=1.4 \mu \mathrm{m}, \mathrm{n}=20$ ), numerous, filiform, branched, septate, hyaline, acute at the apex, not exceeding asci in length. Asci 30-40 ×5-7 $\mu \mathrm{m}(\bar{x}=33.4 \times 5.7 \mu \mathrm{m}, \mathrm{n}=30)$, 8-spored, unitunicate, cylindric-clavate, rounded or medium conical and amyloid apex, short stipitate base, arising from croziers. Ascospores 6-7.5 $\times 1.5-1.8 \mu \mathrm{m}(\bar{x}=7 \times 1.7 \mu \mathrm{m}, \mathrm{n}=40)$, multi-seriate, ellipsoid-clavate, aseptate, hyaline, one side rounded and other side slightly pointed. Asexual morph: Undetermined.

Material examined - UK, Isle of Wight, Calbourne stream, on Apiaceae stem, 11 May 2015, E. B. G. Jones, GJ154a (MFLU 16-0565).

GenBank accessions - LSU- MK591962, ITS- MK584936, SSU- MK585023

Notes - Our new collection from UK grouped with Cistella albidolutea (KUS F52678) and C. grevillei, but with low statistical support (Fig. 51). The ITS data of our collection is similar to Polyphilus sieberi (strain 17A) (517/551-94\% with 8 gaps), Urceolella carestiana (TNS-F18014) (491/526-93\% with 6 gaps), Cistella albidolutea (KUS-F52678) (480/526-91\% with 11 gaps) and to Leohumicola minima (CBS 209.74) (492/535-92\% with 9 gaps). The LSU region is similar to that of Polyphilus frankenii (strain V16) (839/862-97\% with 1 gap), Polyphilus sieberi (strain M03) (840/862-97\% with 1 gap) and to Tetracladium maxilliforme (CCM F-13186) (1080/1176-92\% with 15 gaps).

Cistella granulosella is similar to Psilachnum and Cistella, but differs from Psilachnum by having hairs with granulate walls.

However, its morphology fits with the description of Cistella granulosella provided by Raitviir (2004). Cistella granulosella is similar to C. dentata but differs in lacking dentate margins and slightly smaller asci (Quijada et al. 2015).

Duebenia subcompta Ekanayaka \& K.D. Hyde, sp. nov.

Index Fungorum number: IF556301; Facesoffungi number: FoF 05939; Fig. 55.

Etymology - refers to the similarity the species Duebenia compta

Holotype - MFLU 16-0600

Saprobic on dead stems. Sexual morph: $625-635 \times 225-235 \mu \mathrm{m}(\bar{x}=630 \times 231 \mu \mathrm{m}, \mathrm{n}=$ 10), arising singly or in small groups, sessile, slightly erumpent from the substrate, turbinate, yellow, orange when fresh, brownish yellow when drying. Receptacle concave, disc and the margins are yellow to light brown when fresh. Ectal excipulum 33-38 $\mu \mathrm{m}$ at flanks $(\bar{x}=34.6 \mu \mathrm{m}$, $\mathrm{n}=10$ ), composed of pigmented, thick- and granulate-walled, yellow cells of textura prismatica. Medullary excipulum 22-26 $\mu \mathrm{m}$ at flanks $(\bar{x}=23.4 \mu \mathrm{m}, \mathrm{n}=10)$, composed of narrow, long, thinwalled, yellow cells of textura epidomoidea. Hymenium hyaline. Paraphyses 3-4 $\mu \mathrm{m}$ wide at the tip $(\bar{x}=3.5 \mu \mathrm{m}, \mathrm{n}=20)$, numerous, filiform, obtuse, enlarged at the apex, septate, arising from croziers. Asci $35-45 \times 3.5-5 \mu \mathrm{m}(\bar{x}=39.8 \times 4.5 \mu \mathrm{m}, \mathrm{n}=30), 4-8$-spored, short-pedicellate, unitunicate, cylindric-clavate, conical at the apex, non-amyloid, arising from croziers. Ascospores 6-10 $\times 2.3-3.2 \mu \mathrm{m}(\bar{x}=8.4 \times 2.8 \mu \mathrm{m}, \mathrm{n}=40)$, uniseriate, hyaline, smooth-walled, clavate, fusoid, sometimes allantoid, non-septate, usually with two small polar guttules. Asexual morph: Undetermined.

Material examined - Italy, Arezzo Province [AR], near Poppi, on dead aerial stems of Lathyrus sp., 14 May 2014, Erio Camporesi, IT1873 (MFLU 16-0600). 
GenBank accessions - LSU- MK592002, ITS- MK584982, SSU- MK585058, TEFMK714033

Notes - Our collection from Italy grouped with Duebenia compta from Luxembourg (Fig. 51). The ITS data of our collection is similar to D. compta (G.M. 2015-06-01-1) (298/350-85\% with 6 gaps) and the LSU region is similar to that of Duebenia compta (G.M. 2015-06-01-1) (809/905-89\% with 10 gaps). Duebenia subcompta is characterized by erumpent, orange to brownish apothecia with thick and granulate-walled excipular cells, filiform paraphyses with slightly swollen apices, and aseptate, hyaline ascospores. Duebenia subcompta is similar to D. compta. However, D. compta has 1-septate ascospores and apically curved paraphyses (Hein 1976).

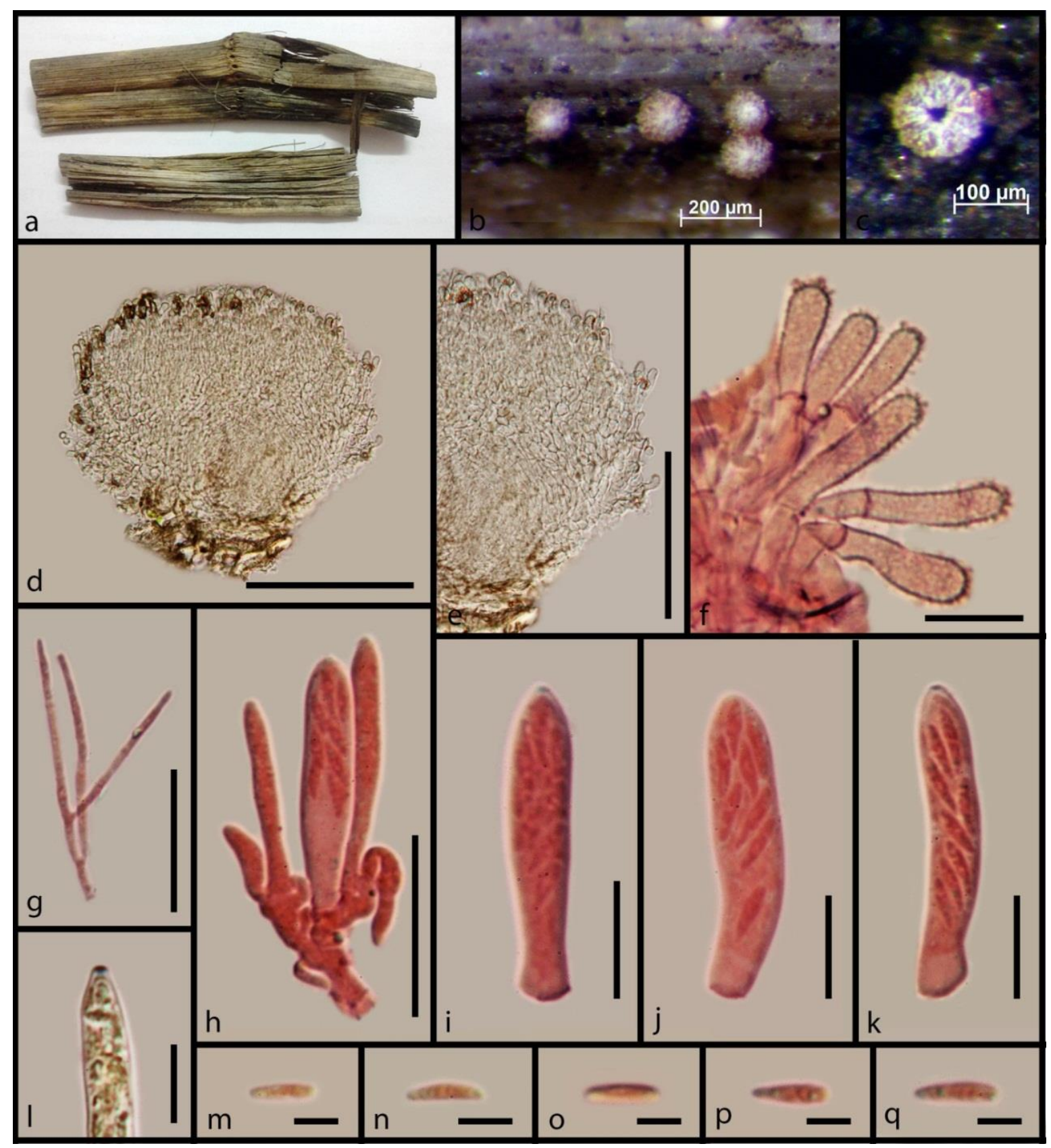

Figure 54 - Morphology of Cistella granulosella (MFLU 16-0565) a Substrate. b Apothecia on wood. c Apothecium on wood. d Cross section of an apothecium. e Vertical section of the apothecium at margin. f Clavate hairs (in Congo red reagent). g Aseptate, branched paraphyses (in Congo red reagent). $\mathrm{h}-\mathrm{k}$ Cylindrical asci (in Congo red reagent). 1 Amyloid ring at apical apex. $\mathrm{m}-$ q Clavate ascospores (in Congo red reagent). Scale bars: $\mathrm{b}=200 \mu \mathrm{m}, \mathrm{c}=100 \mu \mathrm{m}, \mathrm{d}=200 \mu \mathrm{m}, \mathrm{e}=$ $100 \mu \mathrm{m}, \mathrm{f}-\mathrm{h}=20 \mu \mathrm{m}, \mathrm{i}-\mathrm{l}=10 \mu \mathrm{m}, \mathrm{m}-\mathrm{q}=5 \mu \mathrm{m}$. 


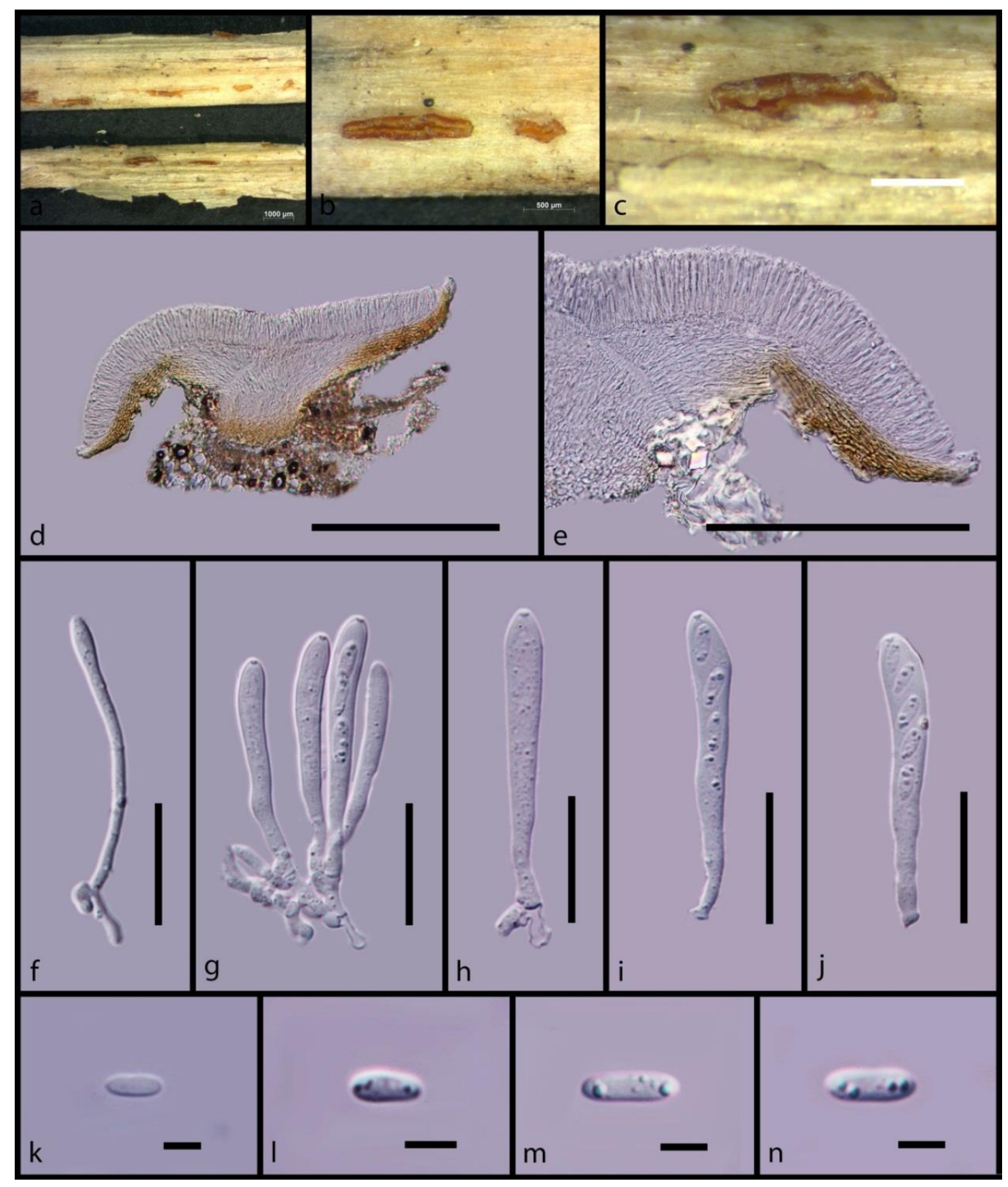

Figure 55 - Morphology of Duebenia subcompta (MFLU 16-0600 holotype) a Substrate, b Apothecia on wood, c Apothecium on wood, d Cross section of an apothecium, e Close up of a vertical section of the apothecium at margin, $f$ Septate paraphyses, $g-j$ Short pedicellate asci with croziers at the base, $\mathrm{k}-\mathrm{n}$ Fusoid ascospores. Scale bars: $\mathrm{a}=1000 \mu \mathrm{m}, \mathrm{b}, \mathrm{c}=500 \mu \mathrm{m}, \mathrm{d}=80 \mu \mathrm{m}, \mathrm{e}=$ $200 \mu \mathrm{m}, \mathrm{f}-\mathrm{j}=20 \mu \mathrm{m}, \mathrm{k}-\mathrm{n}=5 \mu \mathrm{m}$.

Duebenia compta (Sacc.) Nannf. ex B. Hein

Facesoffungi number: FoF 05940; Fig. 56.

Saprobic on dead stems. Sexual morph: $450-500 \times 300-400 \mu \mathrm{m}(\bar{x}=468.4 \times 353.3 \mu \mathrm{m}, \mathrm{n}$ =10). Apothecia scattered, sessile, erumpent from the substrate. Disc brown, concave and smooth. Receptacle cupulate, brown at margins. Ectal excipulum 24.1-33.5 $\mu \mathrm{m}(\bar{x}=28.1 \mu \mathrm{m}, \mathrm{n}=10)$, composed of thin-walled, hyaline cells of textura prismatica. Medullary excipulum $20-40 \mu \mathrm{m}(\bar{x}=$ $32.7 \mu \mathrm{m}, \mathrm{n}=10$ ), composed of narrow, thin-walled, hyaline cells of textura epidomoidea. Hymenium hyaline. Paraphyses 1.5-2 $\mu \mathrm{m}$ wide $(\bar{x}=1.9 \mu \mathrm{m}, \mathrm{n}=20)$, numerous, filiform, lanceolate at the apex, septate, exceeding asci in length, apices of the paraphyses stuck together and develop a pseudoepithecium on the hymenium layer. Asci 55.3-62.2 $\times 6.2-6.6 \mu \mathrm{m}(\bar{x}=58.5 \times 6.4$ $\mu \mathrm{m}, \mathrm{n}=30$ ), 8 -spored, cylindric-clavate, unitunicate, rounded at the apex, faintly amyloid, tapered 
and stipitate base, arising from croziers. Ascospores $6-8 \times 2.5-3 \mu \mathrm{m}(\bar{x}=7.4 \times 2.8 \mu \mathrm{m}, \mathrm{n}=40)$, hyaline, partially biseriate, smooth-walled, clavate, fusoid, 0-1-septate.

Material examined - Italy, Forlì-Cesena Province [FC], Passo della Braccina - Premilcuore, dead aerial stem of Ononis spinosa, 1 June 2014, Erio Camporesi, IT1906 (MFLU 16-0601).

GenBank accessions - LSU- MK592003, ITS- MK584983, SSU- MK585059

Notes - Our new Duebenia collection from Italy grouped with Duebenia subcompta from Italy and D. compta from Luxembourg. The ITS and LSU data of our collection is $99 \%$ similar to that of D. compta (G.M. 2015-06-01-1) (ITS: 545/551-99\% with 3 gaps, LSU: 875/882-99\% with 2 gaps). Morphological characteristics of our collection are similar to the description of D. compta by Hein (1976).

Duebenia compta is characterized by erumpent, dark brown to light brown apothecia with thick and granulate-walled excipular cells, filiform paraphyses with slightly swollen apices, and 01 -septate, hyaline ascospores.

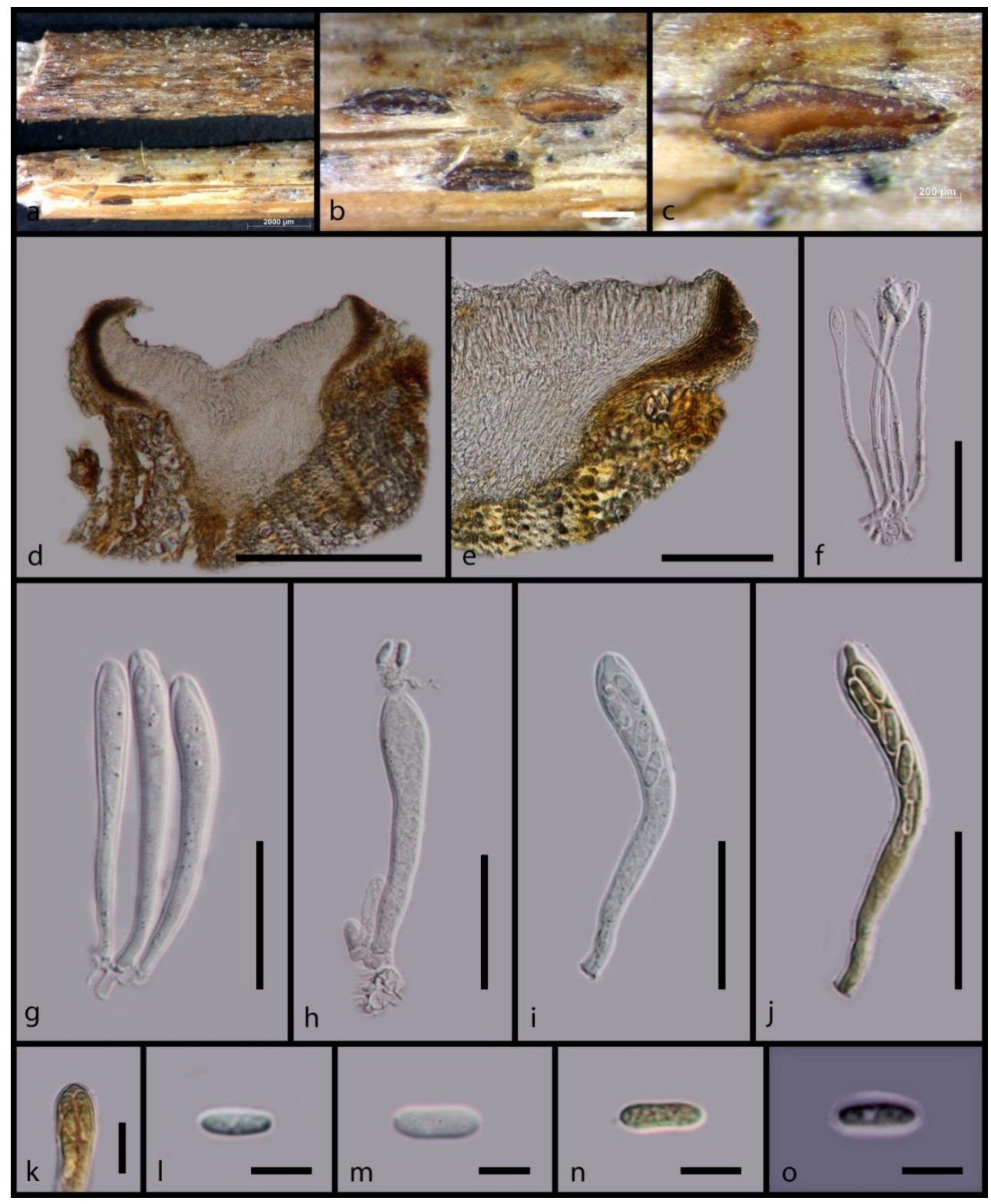

Figure 56 - Morphology of Duebenia compta (MFLU 16-0601) a Substrate. b Apothecia on wood. c Apothecium on wood. d Cross section of an apothecium. e Close up of a vertical section of the apothecium at margin and flanks. f Septate paraphyses. g-j Short pedicellate asci. k Amyloid ring at the ascus apex. $1-\mathrm{o}$ Fusoid ascospores. Scale bars: $\mathrm{a}=2000 \mu \mathrm{m}, \mathrm{b}=500 \mu \mathrm{m}, \mathrm{c}=200 \mu \mathrm{m}, \mathrm{d}=$ $300 \mu \mathrm{m}, \mathrm{e}=100 \mu \mathrm{m}, \mathrm{f}=30 \mu \mathrm{m}, \mathrm{g}-\mathrm{j}=25 \mu \mathrm{m}, \mathrm{k}=10 \mu \mathrm{m}, \mathrm{l}-\mathrm{o}=5 \mu \mathrm{m}$. 


\section{Pezizellaceae Velen.}

= Bloxamiaceae Locq. ex Hern.-Restr., Gené, R.F. Castañeda, J. Mena, Crous \& Guarro

Facesoffungi number: FoF 05941

Taxa are saprobic on dead plant material. Ascomata are apothecial. Apothecia are discoid to cupulate, sessile or stipitate. The margins are smooth or covered by hairs. Hairs are hyaline, cylindrical and septate or aseptate. The ectal excipulum is composed of cells of textura angularis, prismatica or oblita and medullary excipulum is composed of cells of textura intricata. Paraphyses are filiform or lanceolate and septate or aseptate. Asci are 4-8-spored, amyloid or non-amyloid, cylindric-clavate, sometimes arising from croziers. Ascospores are ellipsoid, allantoid to fusoid, 03-septate and guttulate (Baral \& Rämä 2015, Carpenter \& Dumont 1978, Seifert and Carpenter 1987, Jaklitsch et al. 2016). Asexual morphs are hyphomycetous, sporodochial and phialidic. Conidia are fusoid to cylindrical and 0-1-septate (Kowalski \& Bartnik 2010, Koukol 2011, Jaklitsch et al. 2016, Crous et al. 2016, Guatimosim et al. 2016, Hernandez-Restrepo et al. 2017, Hosoya \& Zhao 2016, Spooren 2014).

Notes -In our phylogenetic study, the family Bloxamiaceae clustered within Pezizellaceae. Therefore, we synonymize the later family Bloxamiaceae under the older name Pezizellaceae.

\section{Bisporella shangrilana W.Y. Zhuang \& H.D. Zheng}

Facesoffungi number: FoF 05942; Fig. 58

Saprobic on dead stems. Sexual morph: Apothecia 2-4 × 1-2 mm, arising in clusters, stipitate. Receptacle cupulate. Disc concave. Ectal excipulum 20-25 $\mu \mathrm{m}(\bar{x}=20.3 \mu \mathrm{m}, \mathrm{n}=10)$ in lower flanks, composed of thin-walled, light brown to hyaline, gelatinized cells of textura angularis to intricata. Medullary excipulum $90-110 \mu \mathrm{m}(\bar{x}=102 \mu \mathrm{m}, \mathrm{n}=10)$ in lower flanks, composed of thin-walled, hyaline, gelatinized cells of textura intricata. Hymenium hyaline. Paraphyses 1-2 $\mu \mathrm{m}$ wide $(\bar{x}=1.6 \mu \mathrm{m}, \mathrm{n}=20)$, numerous, filiform, obtuse and slightly swollen at the apex, aseptate, smooth, aguttulate. Asci 85-100 × 8-10 $\mu \mathrm{m}(\bar{x}=98 \times 9 \mu \mathrm{m}, \mathrm{n}=30), 8$-spored, unitunicate, cylindric, apex rounded and amyloid, base stipitate, croziers absent. Ascospores 6.5-10.5 $\times 3-5.2$ $\mu \mathrm{m}(\bar{x}=8.3 \times 4.6 \mu \mathrm{m}, \mathrm{n}=40), 1-2$-seriate, ellipsoid, aseptate, rarely 1-septate, hyaline. Asexual morph: Undetermined.

Material examined - China, Yunnan Province, Shangri-La, Da-cuo National Park, opposite of Bi-Ta Lake, alt. 3551m, 22 September 2015, Bo Li, HK01 (HKAS 90655a), HK03 (HKAS 90655b).

GenBank accessions - HKAS 90655a: LSU- MK591998, ITS- MK584972, SSUMK585053, TEF- MK637050; HKAS 90655b: LSU- MK591997, ITS- MK584971, SSUMK585052, TEF- MK637049

Notes - Our collection from China grouped with the type species of Bisporella shangrilana (HMAS 275569) (Fig. 57). The ITS data of our collections is 99\% similar to that of B. shangrilana (HMAS 275569) (498/499-99\% with 1 gap) and its morphology is similar to the type description of B. shangrilana (Zhuang et al. 2017). Bisporella shangrilana is characterized by its gelatinized excipulum (Zhuang et al. 2017).

\section{Bisporella discedens (P. Karst.) S.E. Carp.}

Facesoffungi number: FoF 05943; Fig. 59

Saprobic on dead stems. Sexual morph: Apothecia $0.7-1 \times 0.2-0.3 \mu \mathrm{m}$, scattered singly, sessile, slightly erumpent from the substrate, cupulate, yellow when fresh. Receptacle concave, disc and the margins are yellow to white when fresh. Hymenium hyaline. Hairs $10-15 \times 1.5-2 \mu \mathrm{m}(\bar{x}=$ $13.4 \times 1.8 \mu \mathrm{m})$, cylindric, thick-walled, pigmented, 3 -septate. Ectal excipulum $17-23 \mu \mathrm{m}(\bar{x}=19.9$ $\mu \mathrm{m}, \mathrm{n}=10$ ), composed of thin-walled, hyaline cells of textura prismatica. Medullary excipulum 60-70 $\mu \mathrm{m}(\bar{x}=64.3 \mu \mathrm{m}, \mathrm{n}=10)$, composed of narrow, thin-walled, hyaline cells of textura epidomoidea. Paraphyses $0.9-1.3 \mu \mathrm{m}$ wide $(\bar{x}=1.1 \mu \mathrm{m}, \mathrm{n}=20)$, numerous, filiform, obtuse at the apex, septate, septate. Asci $65-75 \times 4.7-5.5 \mu \mathrm{m}(\bar{x}=73.1 \times 5.2 \mu \mathrm{m}, \mathrm{n}=30)$, cylindric-clavate, unitunicate, rounded apex, non-amyloid, tapered and stipitate base, arising from croziers. 
Ascospores 7.2-9.1 $\times 2.5-3 \mu \mathrm{m}(\bar{x}=8.7 \times 2.7 \mu \mathrm{m}, \mathrm{n}=40)$, fusiform, hyaline, 1 -septate, smoothwalled. Asexual morph: hyphomycetous, sporodochial, on the surface of the receptacle of the apothecia. Conidiogenous cells phialidic, dark brown. Conidia $2-3 \times 1 \mu \mathrm{m}$, ellipsoid to ovoid, aseptate, hyaline, with two guttules.

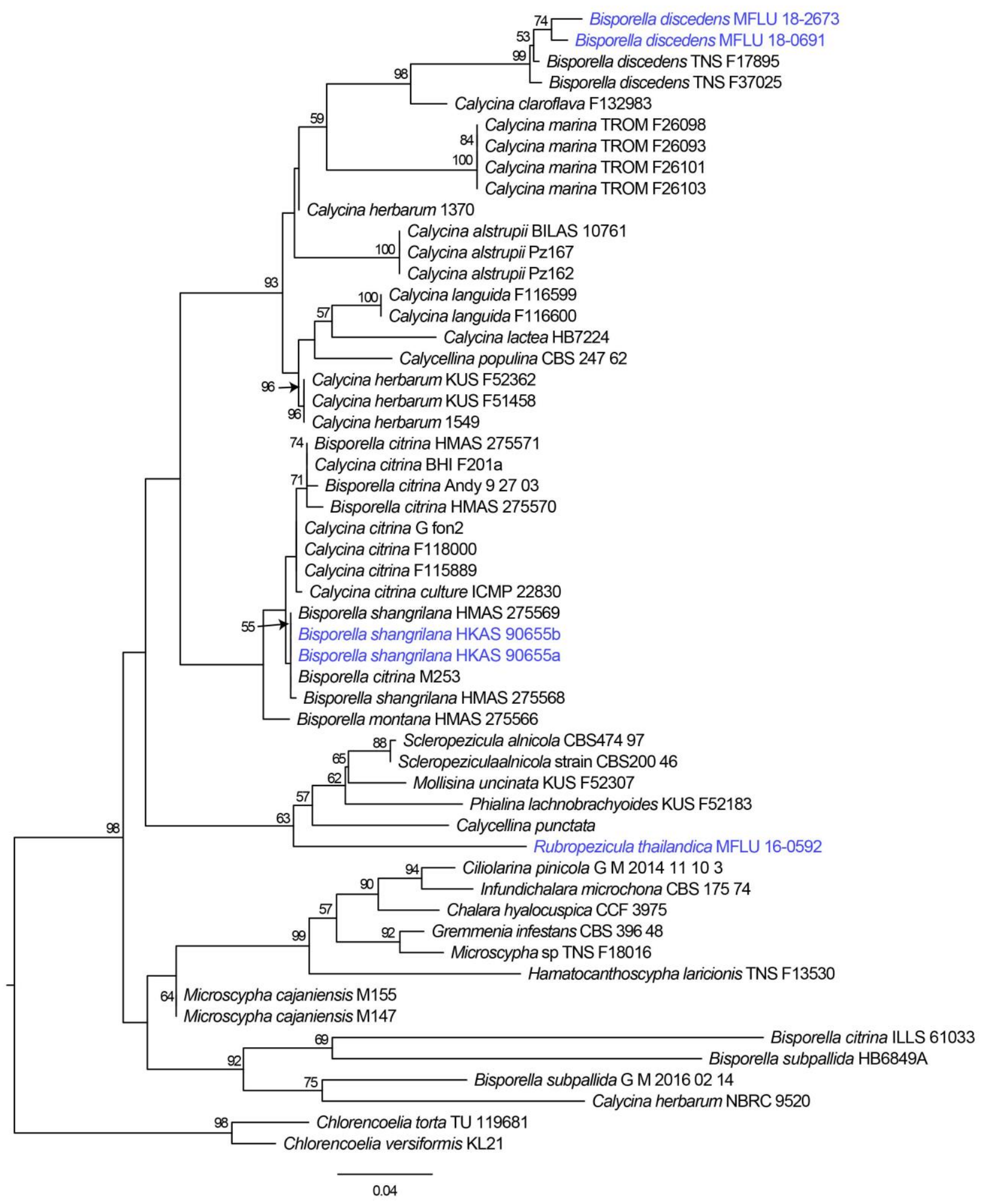

Figure 57 - Phylogram generated from maximum likelihood analysis of sequences of Pezizellaceae based on ITS sequence data. MLBP values $\geq 50 \%$ are given near the nodes. Strain/culture numbers are given after the taxon names. The tree is rooted with Chlorencoelia versiformis (KL21) and Chlorencoelia torta (TU 119681). 


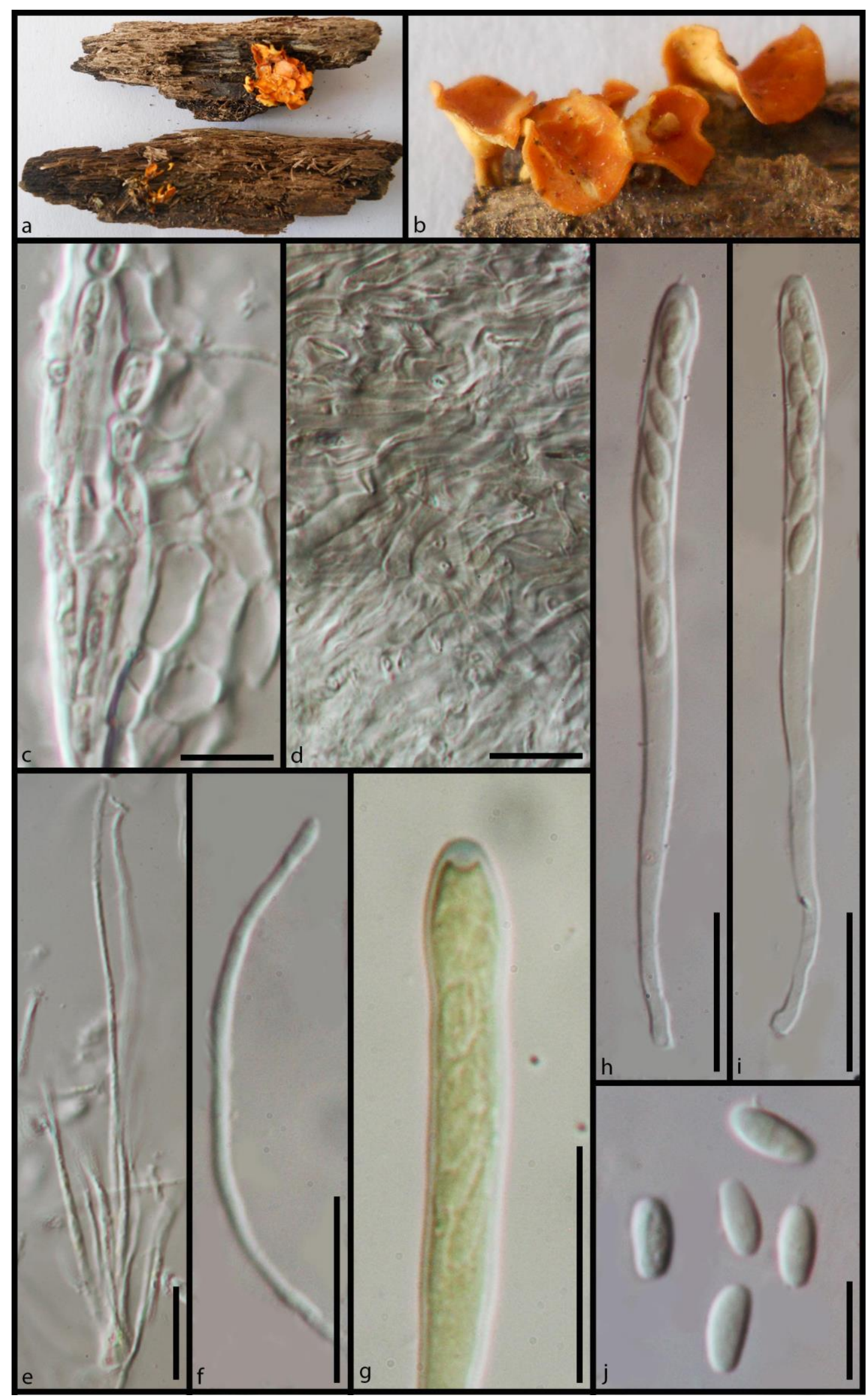

Figure 58 - Morphology of Bisporella shangrilana (HKAS 90655) a, b Apothecia on wood. c Ectal excipular cells. d Medullary excipular cells. e, f Filiform paraphyses. g Amyloid ascus apex. $\mathrm{h}-\mathrm{i}$ Cylindrical asci. $\mathrm{j}$ Ellipsoid ascospores. Scale bars: $\mathrm{c}-\mathrm{i}=20 \mu \mathrm{m}, \mathrm{j}=10 \mu \mathrm{m}$. 
Material examined - Thailand, Chiang Mai Province, Mushroom Research Center, 1 March 2015, A. H. Ekanayaka HD014 (MFLU 18-2673), Thailand, Mushroom Research Center, Chiang Mai Province, 18 July 2017, A. H. Ekanayaka, HD077 (MFLU 18-0691).

GenBank accessions - MFLU 18-2673: LSU- MK591982, ITS- MK584952, SSUMK585035; MFLU 18-0691: LSU- MK591996, ITS- MK584970, SSU- MK585043, TEFMK714026

Notes - Our collections from Thailand grouped with Bisporella discedens (TNS F17895) from Japan (Fig. 57) and the whole clade received strong statistical support of 99\%. The ITS data of our collection is $98 \%$ similar to that of $B$. discedens strains TNS:F37025 (517/528-98\% with 4 gaps) and TNS:F17895 (514/525-98\% with 5 gaps). Bisporella discedens is characterized by whitish to yellowish apothecia with a thick layer of medullary excipulum of textura epidomoidea, cylindric-clavate asci and 1-septate, ellipsoid ascospores (Carpenter \& Dumont 1978) and our collection agrees with these features. In our collection we observed a bloxamia-like asexual morph to Bisporella discedens.

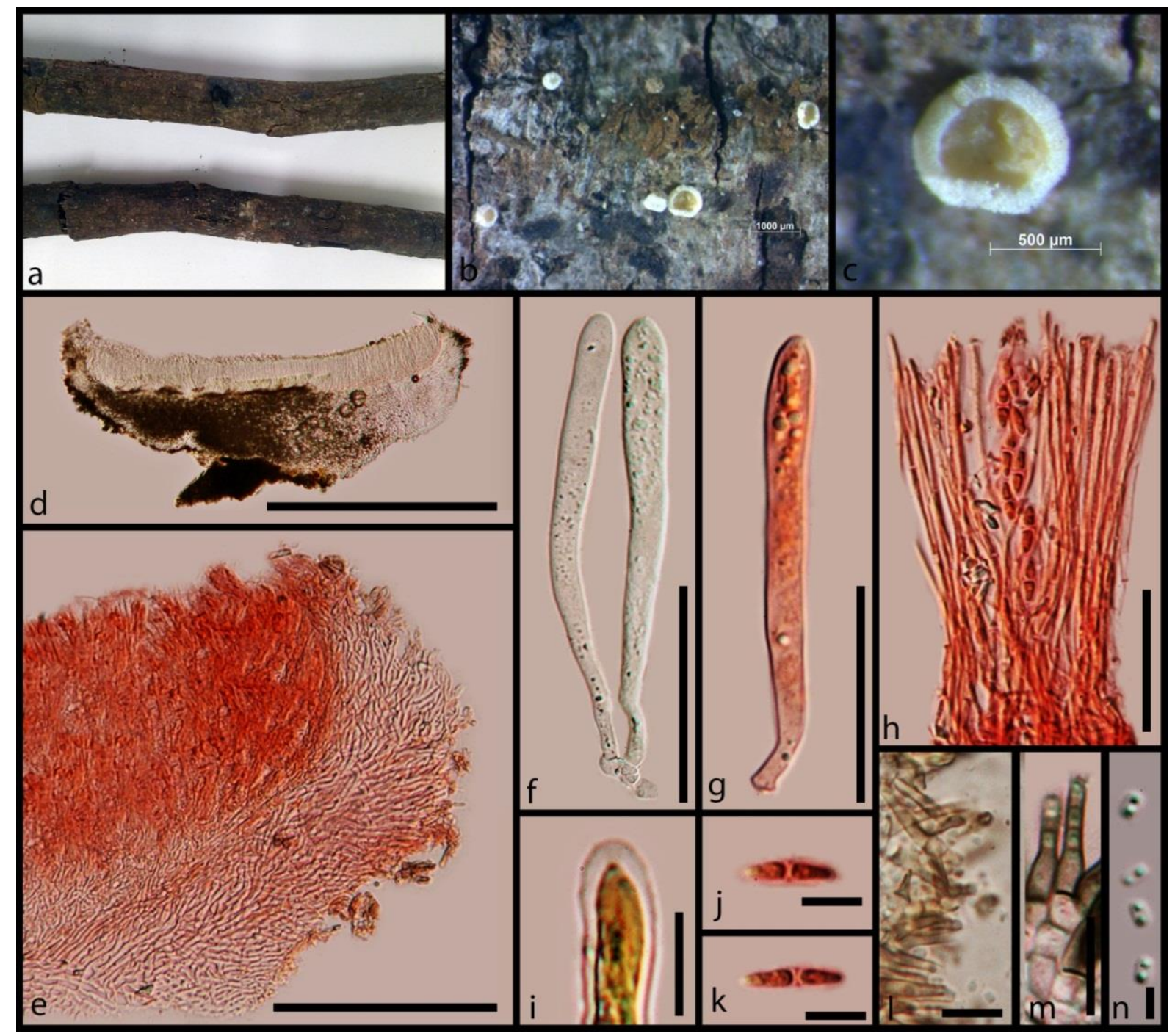

Figure 59 - Morphology of Bisporella discedens (MFLU 18-2673) a Substrate. b Apothecia on wood. c Apothecium on wood. d Cross section of an apothecium. e Close up of a vertical section of the apothecium at margin (in Congo red reagent). $\mathrm{f}$, g Stipitate asci (f mounted in water and $\mathrm{g}$ in Congo red reagent). h Septate paraphyses with ascus (in Congo red reagent). i Close up of ascus apex. j, k Hyaline, single septate ascospores (in Congo red reagent). $1, \mathrm{~m}$ Conidiogenous cells. $\mathrm{n}$ Conidia. Scale bars: $\mathrm{b}=1000 \mu \mathrm{m}, \mathrm{c}=500 \mu \mathrm{m}, \mathrm{d}=500 \mu \mathrm{m}, \mathrm{e}=100 \mu \mathrm{m}, \mathrm{f}, \mathrm{g}=30 \mu \mathrm{m}, \mathrm{h}=30, \mathrm{i}=$ $10 \mu \mathrm{m}, \mathrm{j}, \mathrm{k}=5 \mu \mathrm{m}, \mathrm{l}, \mathrm{m}=10 \mu \mathrm{m}, \mathrm{n}=2 \mu \mathrm{m}$. 
Rubropezicula Ekanayaka \& K.D. Hyde, gen. nov.

Index Fungorum number: IF556302; Facesoffungi number: FoF 05944

Etymology - refers to the similarity with the genus Pezicula and presence of red pigments in excipular hairs.

Saprobic on dead stems. Sexual morph: Apothecia arising in small groups, sessile to substipitate, erumpent. Receptacle cupulate, disc flat and whitish, margins are covered with hairs. Hairs cylindric, septate, composed of red pigments that readily dissolve in $\mathrm{KOH}$ and slightly dissolve in water. Ectal excipulum composed of cells of textura angularis. Medullary excipulum composed of cells of textura prismatica. Hymenium hyaline to reddish. Paraphyses numerous, filiform, obtuse and slightly swollen at the apex, septate, not exceeding the asci in length, smooth, aguttulate. Asci 8-spored, unitunicate, cylindric-clavate, rounded or medium conical at the apex, amyloid, stipitate base, croziers absent. Ascospores ovoid, septate, hyaline.

\section{Type species: Rubropezicula thailandica}

\section{Rubropezicula thailandica Ekanayaka \& K.D. Hyde, sp. nov.}

Index Fungorum number: IF556303; Facesoffungi number: FoF 05945; Fig. 60.

Etymology - refers to the country where Holotype collected

Holotype - MFLU 16-0592

Saprobic on dead stems. Sexual morph: 408-434 × 170-200 $\mu \mathrm{m}(\bar{x}=425.7 \times 198.3 \mu \mathrm{m}, \mathrm{n}$ $=10$ ), arising in small groups, sessile to sub-stipitate, erumpent. Receptacle cupulate, disc flat and white, margins are red when fresh. Hairs 100-150 × 1-2.7 $\mu \mathrm{m}(\bar{x}=130 \times 1.7 \mu \mathrm{m}, \mathrm{n}=30)$, cylindric, septate, walls usually thin, composed of red pigments that readily dissolve in $\mathrm{KOH}$ and slightly dissolve in water. Ectal excipulum $38-42 \mu \mathrm{m}(\bar{x}=40.8 \mu \mathrm{m}, \mathrm{n}=10)$ in lower flanks, composed of thin-walled, dark brown cells of textura angularis. Medullary excipulum 10-15 $\mu \mathrm{m}$ $(\bar{x}=12 \mu \mathrm{m}, \mathrm{n}=10)$ in lower flanks, composed of thin-walled, brown to hyaline cells of textura prismatica. Hymenium hyaline. Paraphyses $1.4-2.4 \mu \mathrm{m}$ wide $(\bar{x}=1.8 \mu \mathrm{m}, \mathrm{n}=20)$, numerous, filiform, obtuse and slightly swollen at the apex, septate, not exceeding the asci in length, smooth, aguttulate. Asci 80-120 × 10-20 $\mathrm{m}(\bar{x}=102.2 \times 14.8 \mu \mathrm{m}, \mathrm{n}=30), 8$-spored, unitunicate, cylindric-clavate, rounded or medium conical at the apex, amyloid, stipitate base, croziers absent. Ascospores 19.3-23.9 × 6.3-8.3 $\mu \mathrm{m}(\bar{x}=22.2 \times 7.6 \mu \mathrm{m}, \mathrm{n}=40), 1-2$-seriate, ovoid, septate, hyaline. Asexual morph: Undetermined.

Material examined - Thailand, Chiang Mai Province, Mushroom Research Center, on dead stems, 19th July 2015, A.H. Ekanayaka, HD031 (MFLU 16-0592).

GenBank accessions - ITS- MK584963

Notes - In our phylogenetic analysis of Pezizellaceae (Fig. 57), our collection formed an independent clade basal to Scleropezicula-Phialina clade with strong statistical support of $63 \%$. The ITS data of our collection is $90 \%$ similar to that of Scleropezicula alnicola (CBS200.46) $(503 / 557-90 \%)$ but differ by 54 base pairs with 10 gaps, $85 \%$ to Bisporella citrina (420526MF0079) (466/546-85\%), but differ by 80 base pairs with 16 gaps. Therefore here we considered the phylogenetic position of our collection within Pezizellaceae and the guidelines for introducing new taxa provided by Jeewon \& Hyde (2016), and introduce the new genus Rubropezicula here.

The genus Rubropezicula is close to Scleropezicula and Phialina by having sub-stipitate, cupulate apothecia, filiform paraphyses with swollen apices, and septate, ovoid ascospores (Verkley 1999). However, Rubopezicula differs from Scleropezicula and Phialina by having red pigmented excipular hairs.

\section{Rhytismataceae Chevall.}

$=$ Cudoniaceae P.F. Cannon

Facesoffungi number: FoF 05946 
Taxa are saprobic on dead plant material or parasitic (Wang et al. 2006a). Ascomata are apothecial. Apothecia are long-stipitate, clavate, capitate or spathulate or sessile, erumpent, circular, navicular or hysteriform, clypeate and opening by longitudinal split or radial fissures. The ectal excipulum is composed of cells of textura angularis or textura porrecta and medullary excipulum is reduced or

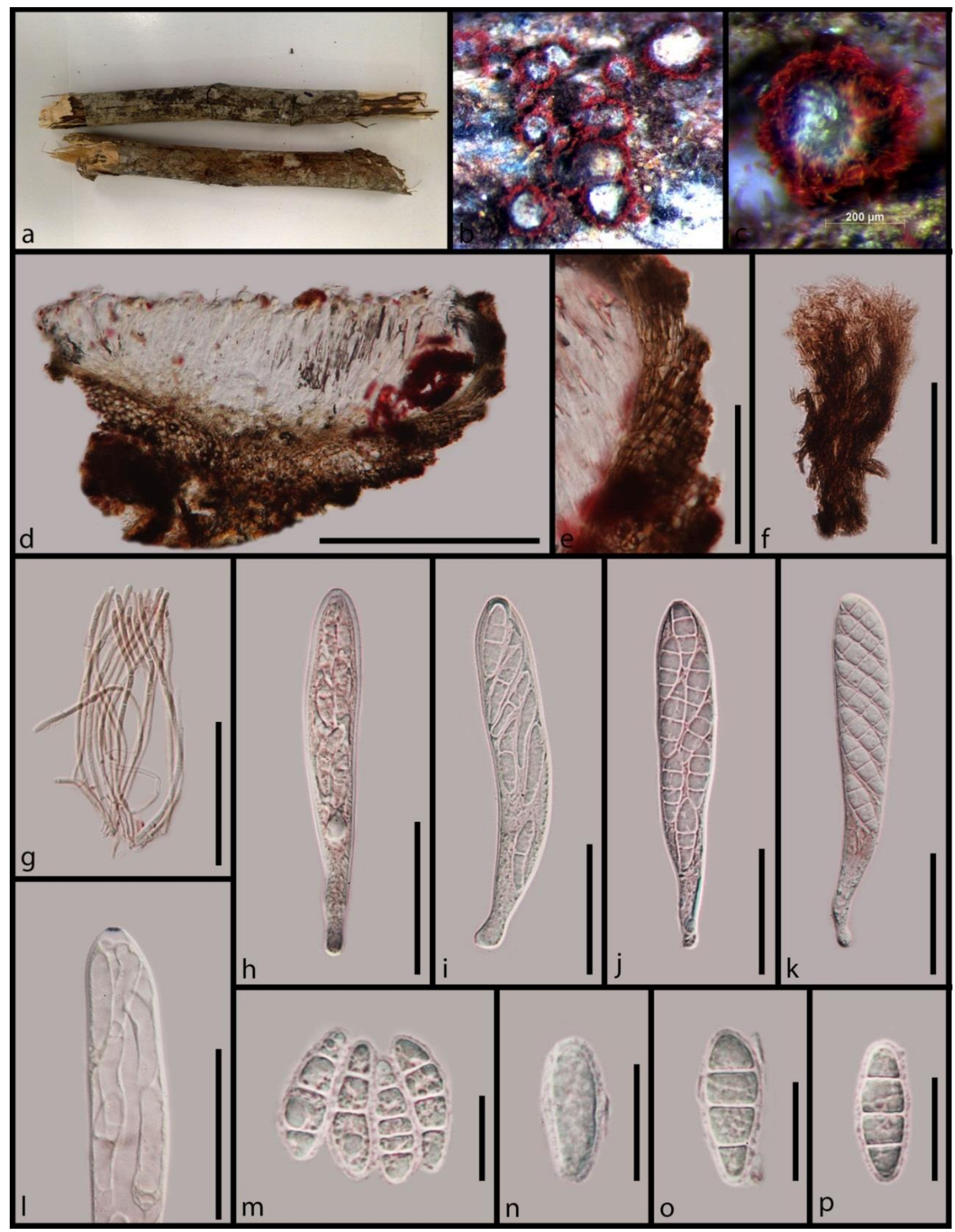

Figure 60 - Morphology of Rubropezicula thailandica (MFLU 16-0592 holotype) a Substrate. b Apothecia on wood. c Apothecium on wood. d Cross section of an apothecium. e Close up of the cross section of apothecium at margins. f Long cylindrical hairs. g Cylindrical paraphyses. $\mathrm{h}-\mathrm{k}$ Cylindric-clavate asci. 1 Apex of amyloid asci in Melzer's reagent. $\mathrm{m}-\mathrm{p}$ Obovoid ascospores. Scale bars: $\mathrm{c}=200 \mu \mathrm{m}, \mathrm{d}=200 \mu \mathrm{m}, \mathrm{e}=70 \mu \mathrm{m}, \mathrm{f}=100 \mu \mathrm{m}, \mathrm{g}=50 \mu \mathrm{m}, \mathrm{h}-1=40 \mu \mathrm{m}, \mathrm{m}-\mathrm{p}=15 \mu \mathrm{m}$. (Note: all the figures appeared reddish, as it is impossible to get rid of pigments produced by hairs) 
composed of cells of textura intricata to prismatica. Paraphyses are rarely absent, filiform, mostly aseptate, branched or unbranched, sometimes apically slightly swollen and strongly curved and hyaline. Asci are 4-8-spored, mostly non-amyloid, cylindric-clavate and arising from croziers. Ascospores are ovoid, ellipsoid, clavate, sub-cylindrical, fusoid or filiform, hyaline, usually aseptate, apex slightly curved, base strongly tapered and sometimes apex partly covered by a gel cap (Wang et al. 2006a, Ge et al. 2014, Geesteranus 1972, Wang et al. 2002, 2006b, Cannon \& Minter 1986, Johnston 2001a, b, Minter 1981, Sherwood 1980, Hou \& Piepenbring 2006, 2009, Tanney \& Seifert 2017). Asexual morphs are pycnidial. Conidiogenesis is holoblastic, with sympodial proliferation. Conidia are ellipsoid to fusoid, rod-shape, hyaline and aseptate (Hou \& Piepenbring 2006, Wang et al. 2006a, Ge et al. 2014).

Notes - In our phylogenetic analysis taxa assigned to Cudoniaceae nested within Rhytismataceae, instead of forming a monophyletic clade. Taxa in Cudoniaceae were formerly classified within Geoglossaceae considering their morphological similarities (clavate apothecia, filiform ascospores etc.). Later the family was placed under Rhytismatales considering their genetic similarities. However, we synonymize the family under Rhytismataceae according to its phylogenetic placement. The same phylogenetic placement of Cudoniaceae taxa was observed by Lantz et al. (2011). The taxa of Cudoniaceae and Rhytismataceae are very similar in their ascus morphology, filiform ascospores with a sheath and apically curled paraphyses (Lantz et al. 2011, Ge et al. 2014, Song et al. 2012, Yang et al. 2011).

Lophodermium microsporum Ekanayaka \& K.D. Hyde, sp. nov.

Index Fungorum number: IF556304; Facesoffungi number: FoF 05947; Fig. 62

Etymology - refers to small ascospores

Holotype - MFLU 15-3100

Weak pathogenic on dying leaves and leafstalks. Sexual morph: Apothecia $0.3-0.5 \times 0.5-0.8$ $\mathrm{mm}$, arising singly, sessile, erumpent, opening by a longitudinal split. Receptacle palisade layer of asci and paraphyses. Disc flat. Excipulum 15-24 $\mu \mathrm{m}(\bar{x}=20.3 \mu \mathrm{m}, \mathrm{n}=10)$ thick at lower side walls, composed of thin-walled cells of textura angularis, cells in outer layer are dark brown to black and inner cells are light brown to hyaline. Hymenium hyaline. Paraphyses $1.5-2 \mu \mathrm{m}$ wide $(\bar{x}$ $=1.7 \mu \mathrm{m}, \mathrm{n}=20$ ), numerous, filiform, obtuse and slightly curved at the apex, rarely septate, exceeding the asci in length, smooth, guttulate. Asci 63-68 $\times 6-9 \mu \mathrm{m}(\bar{x}=66.2 \times 7 \mu \mathrm{m}, \mathrm{n}=30), 8$ spored, unitunicate, cylindric, conical and non-amyloid apex, short-stipitate base, arising from croziers. Ascospores 34-38 $\times 1.8-2.2 \mu \mathrm{m}(\bar{x}=34.5 \times 1.9 \mu \mathrm{m}, \mathrm{n}=40)$, multi-seriate, fusoid, acute tips, aseptate, hyaline, guttulate. Asexual morph: Undetermined.

Material examined - Russia, Rostov region, Shakhty City District, flowerbed, weak parasitic on living, dying, and dead leaves and leafstalks of Paeonia lactiflora Pall. (Paeoniaceae), 20 September 2015, Timur S. Bulgakov, T-959 (MFLU 15-3100).

GenBank accessions - ITS- MK584994, SSU- MK585019

Notes - The phylogenetic analysis of ITS and LSU data indicates that our collection belongs to Lophodermium (Fig. 61). The ITS region of Lophodermium microsporum is similar to that of $L$. agathidis (strain T11) (415/460-90\% with 4 gaps) and to L. minor (strain H12) (415/461-90\% with 6 gaps) from China. Lophodermium microsporum is positioned in a moderately supported independent clade and nested close to L. pini-taiwanensis. Lophodermium microsporum differs from L. pini-taiwanensis, L. minor and L. agathidis in possessing shorter asci and ascospores (Johnston 1989, Minter \& Hetiige 1983, Li et al. 2016). Lophodermium paeoniae was the only member of the Rhytismatales known on the plant genus Paeonia. Our new species also recorded from Paeonia lactiflora. However our new species differ from $L$. paeoniae by having smaller asci

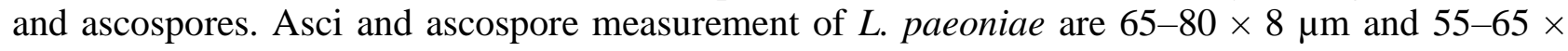
$1.5 \mu \mathrm{m}(\operatorname{Rehm} 1897)$. 


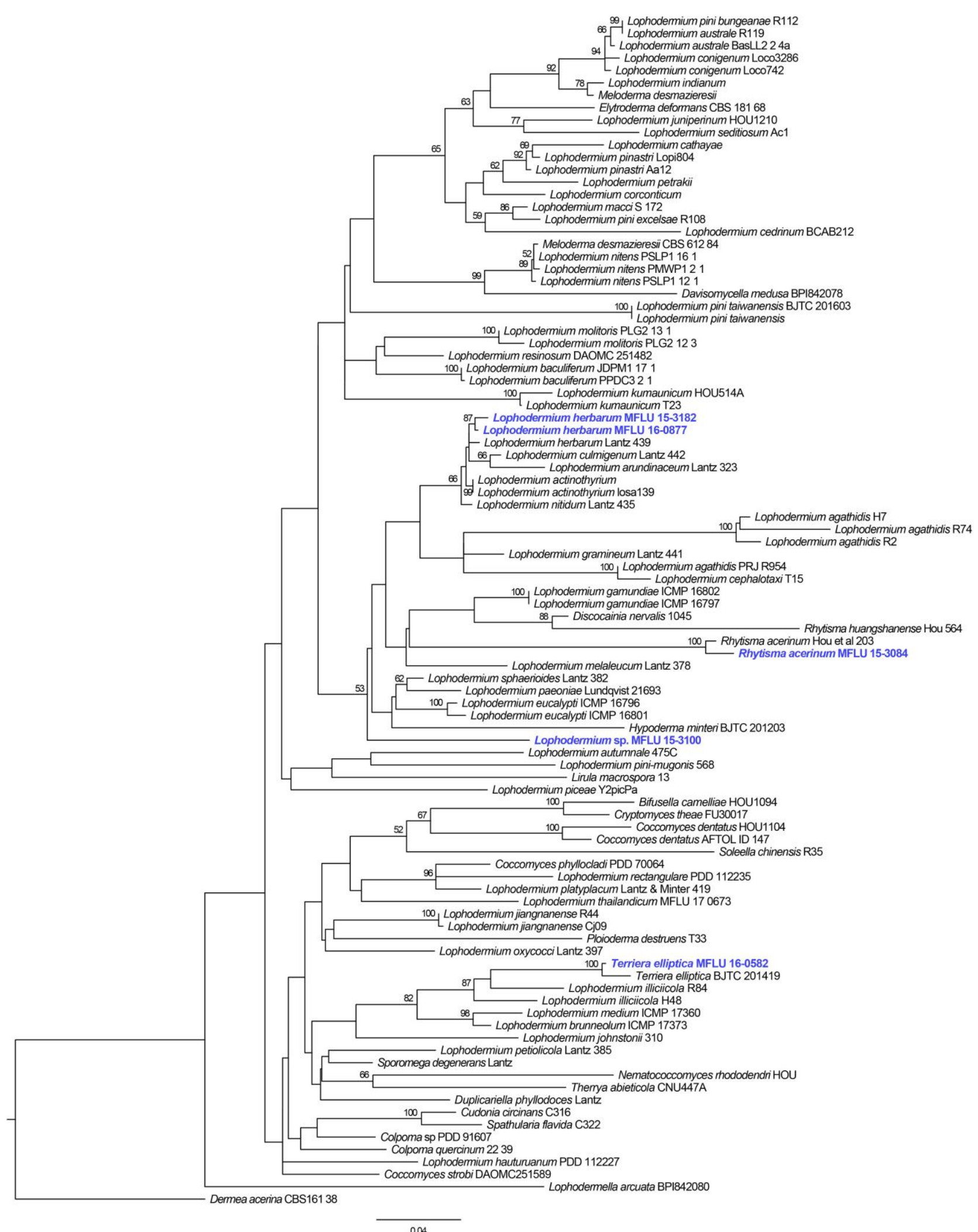

Figure 61 - Phylogram generated from maximum likelihood analysis of sequences of Rhytismataceae based on ITS, LSU sequence data. MLBP values $\geq 50 \%$ are given near the nodes. Strain/culture numbers are given after the taxon names. The tree is rooted with Dermea acerina (CBS161 38). 


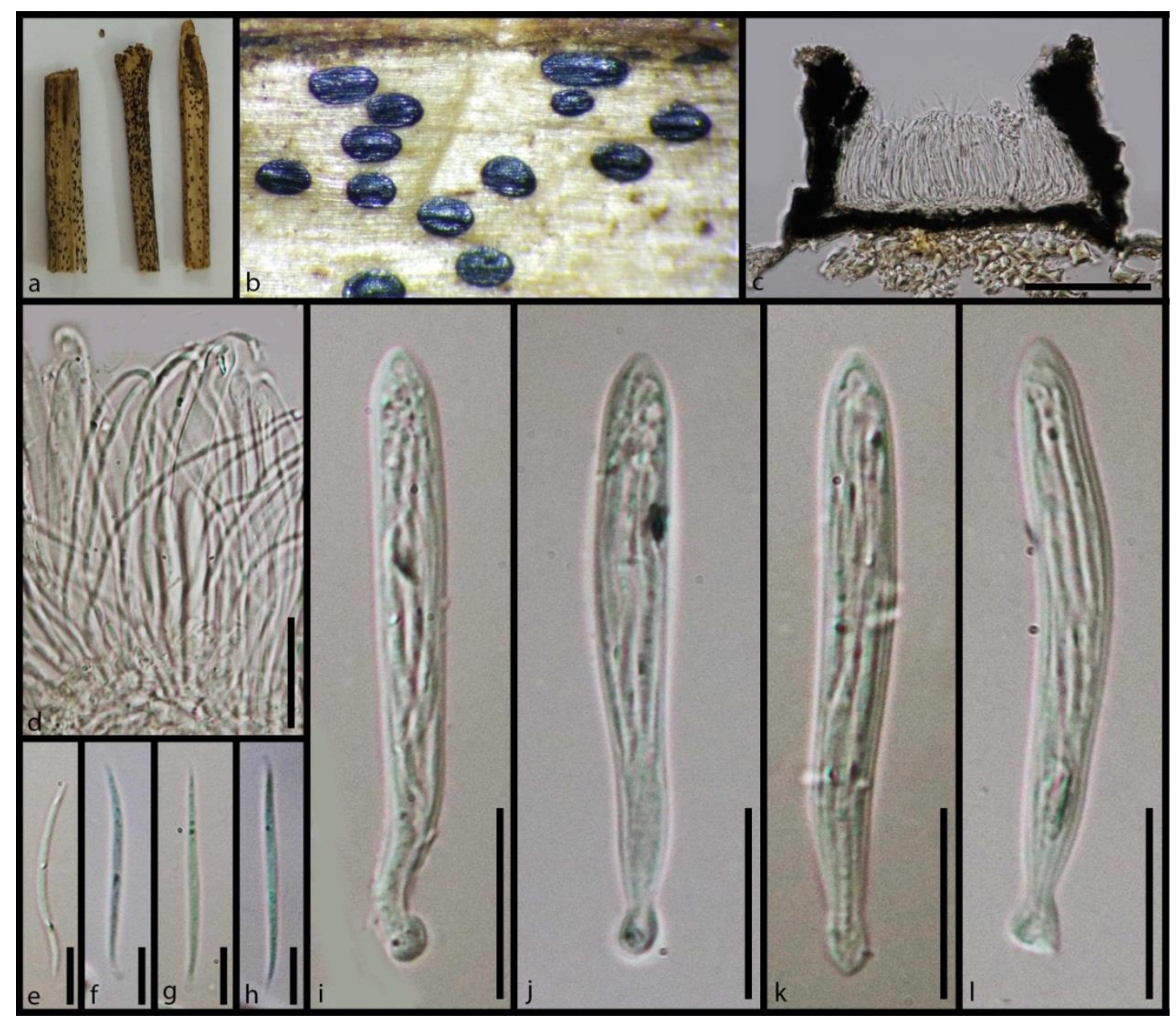

Figure 62 - Morphology of Lophodermium microsporum (MFLU 15-3100 holotype) a Substrate. b Apothecia on wood. c Cross section of an apothecium. $d$ Part of the hymenium layer showing asci and paraphyses. e- $\mathrm{h}$ Fusoid ascospores. $\mathrm{i}-1$ Cylindrical asci. Scale bars: $\mathrm{c}=100 \mu \mathrm{m}, \mathrm{d}=25 \mu \mathrm{m}$, e$\mathrm{h}=10 \mu \mathrm{m}, \mathrm{i}-\mathrm{l}=20 \mu \mathrm{m}$.

\section{Lophodermium herbarum (Fr.) Fuckel}

Facesoffungi number: FoF 05948; Fig. 63

Saprobic on dead stems and leaves. Sexual morph: Apothecia $0.5-1 \times 0.3-0.6 \mathrm{~mm}$, arising singly, sessile, ellipsoid, slightly erumpent. Receptacle palisade layer of asci and paraphyses. Disc flat to slightly concave. Excipulum $30-35 \mu \mathrm{m}(\bar{x}=33 \mu \mathrm{m}, \mathrm{n}=10)$ in lower side walls, composed of thin-walled cells of textura angularis, cells in outer layer are dark brown to black and inner cells are light brown to hyaline. Hymenium hyaline. Paraphyses $1-2.5 \mu \mathrm{m}$ wide $(\bar{x}=2.2 \mu \mathrm{m}, \mathrm{n}=20$ ), numerous, filiform, apices obtuse, slightly curved and attached together with gelatinized material, septate, smooth, guttulate. Asci 80-110 $\times 8-10 \mu \mathrm{m}(\bar{x}=85.3 \times 9.3 \mu \mathrm{m}, \mathrm{n}=30)$, 8-spored, unitunicate, cylindric-clavate, conical and non-amyloid apices, short-stipitate base, arising from croziers. Ascospores 40-50 $\times 1-2 \mu \mathrm{m}(\bar{x}=44.5 \times 1.5 \mu \mathrm{m}, \mathrm{n}=40)$, multi-seriate, fusoid, aseptate, hyaline, guttulate, acute tips. Asexual morph: Undetermined.

Material examined - Russia, Arkhangelsk region, Akhangelsk City, Maimaksansky City District, saprobic or weak parasitic on dead stems of Calamagrostis epigeios (L.) Roth (Poaceae), 2 August 2015, Gennady V. Okatov, AR-042 (MFLU 15-3182). Italy, Ravenna Province [RA], Lido di Dante, dead aerial stem of Ammophila arenaria (L.) Link (Poaceae), 9 February 2016, Erio Camporesi IT2829 (MFLU 16-0877).

GenBank accessions - MFLU 15-3182: LSU- MK591954, SSU- MK585011; MFLU 160877: LSU- MK592005, ITS- MK584985, SSU- MK585061 
Notes - Our strains of Lophodermium from Russia and Italy grouped with L. herbarum- L. actinothyrium clade (Fig. 61). The ITS region of our collections is similar to that of $L$. actinothyrium (isolate losa139) (437/442-99\% with no gaps) from Argentina, while the LSU region is similar to that of L. herbarum (voucher Lantz 439) (733/736 -99\% with no gaps), L. nitidum (Lantz 435) (771/778-99\% with 2 gaps) and L. culmigenum (Lantz 442) (768/778-99\% with 2 gaps). LSU data of L. actinothyrium and ITS data of L. herbarum, L. culmigenum and L. nitidum are not available in GenBank to compare with our data.

The morphological characters of our collection are in agreement with the description for $L$. herbarum provided by Tehon et al. (1935). Therefore, we name our collection as Lophodermium herbarum.

\section{Terriera elliptica T.T. Zhang \& C.L. Hou}

Facesoffungi number: FoF 05949; Fig. 64

Saprobic on dead stems. Sexual morph: Apothecia $0.8-1.5 \times 0.2-0.8 \mathrm{~mm}$ arising singly or in small groups, erumpent, black, ellipsoid. Receptacle hysteriform. Disc flat to concave. Excipulum 8-12 $\mu \mathrm{m}$ at lower side walls, composed of thin-walled, black cells of textura angularis, cells in outer layer are dark brown to black and inner cells are light brown to hyaline. Hymenium hyaline. Paraphyses $0.8-1.5 \mu \mathrm{m}$ wide, filiform, branched, septate, exceeding the asci in length and form an epithecium, smooth, eguttulate. Asci 95-130 × 8-15 $\mu \mathrm{m}$, arising from croziers, 8-spored, unitunicate, cylindric, rounded and non-amyloid apex, long-stipitate base, croziers absent. Ascospores 50-70 $\times 2-3 \mu \mathrm{m}$, multi-seriate, filiform with acute apices, aseptate, hyaline, guttulate with thin gelatinous sheath. Asexual morph: Undetermined.

Material examined - Thailand, Chiang Rai Province, Hyde's farm, 22 April 2015, A. H. Ekanayaka, HD020 (MFLU 16-0582).

GenBank accessions - ITS- MK584954

Notes - Our collection from Thailand grouped with Terriera elliptica from China (Fig. 61). The ITS region of our collection is similar to the ITS data of the type material of T. elliptica (BJTC 201419) (736/746-99\% with 2 gaps). Terriera elliptica is characterized by elliptic hysteriform apothecia erumpent to the substrate, filiform branched paraphyses form an epithecium, cylindric asci, arising from croziers and filiform ascospores with acute apices. Morphology of our collection is similar to the description from Zhang et al. (2015).

\section{Meloderma sp1}

Fig. 65

Saprobic on dead stems. Sexual morph: Apothecia $1-1.5 \times 0.5-0.8 \mathrm{~mm}$, arising singly or in small groups, erumpent, black. Receptacle palisade layer of asci and paraphyses, disc flat. Excipulum 15-20 $\mu \mathrm{m}$ composed of thin-walled, black cells of textura angularis, cells in outer layer are dark brown to black and inner cells are hyaline. Hymenium hyaline. Paraphyses 1.5-2.3 $\mu \mathrm{m}$ wide, subcylindrical, filiform and circinate or curved at the apex, aseptate, exceeding the asci in length, smooth, eguttulate. Asci 90-100 × 10-15 $\mu \mathrm{m}, 8$-spored, unitunicate, cylindric-clavate, conical and non-amyloid apex, gradually tapering, long-stipitate base, croziers absent. Ascospores 15-20 $\times 2-3 \mu \mathrm{m}$, multi-seriate, narrowly obovoid, 1-septate, hyaline, guttulate, tapering towards the base.

Material examined - Italy, Forlì-Cesena [FC] Province, Tontola di Predappio, dead land branch of Robinia pseudacacia, 5 September 2014, Erio Camporesi, IT2085 (MFLU 16-0603).

Notes - This strain was collected from Italy, but ascospores failed to germinate and the DNA extraction directly from fruiting bodies did not succeed. Our strain is similar to the genus Meloderma by having ellipsoid apothecia, with wider upper wall near ascocarp opening (clearly seen in vertical section of apothecium), filiform paraphyses, often circinate at their tips, clavate asci tapering gradually to base, and narrowly obovoid ascospores tapering towards the base (Johnston 1988). Therefore, we refer this collection to Meloderma sp1 untill we have more data to identify this collection to species level. 


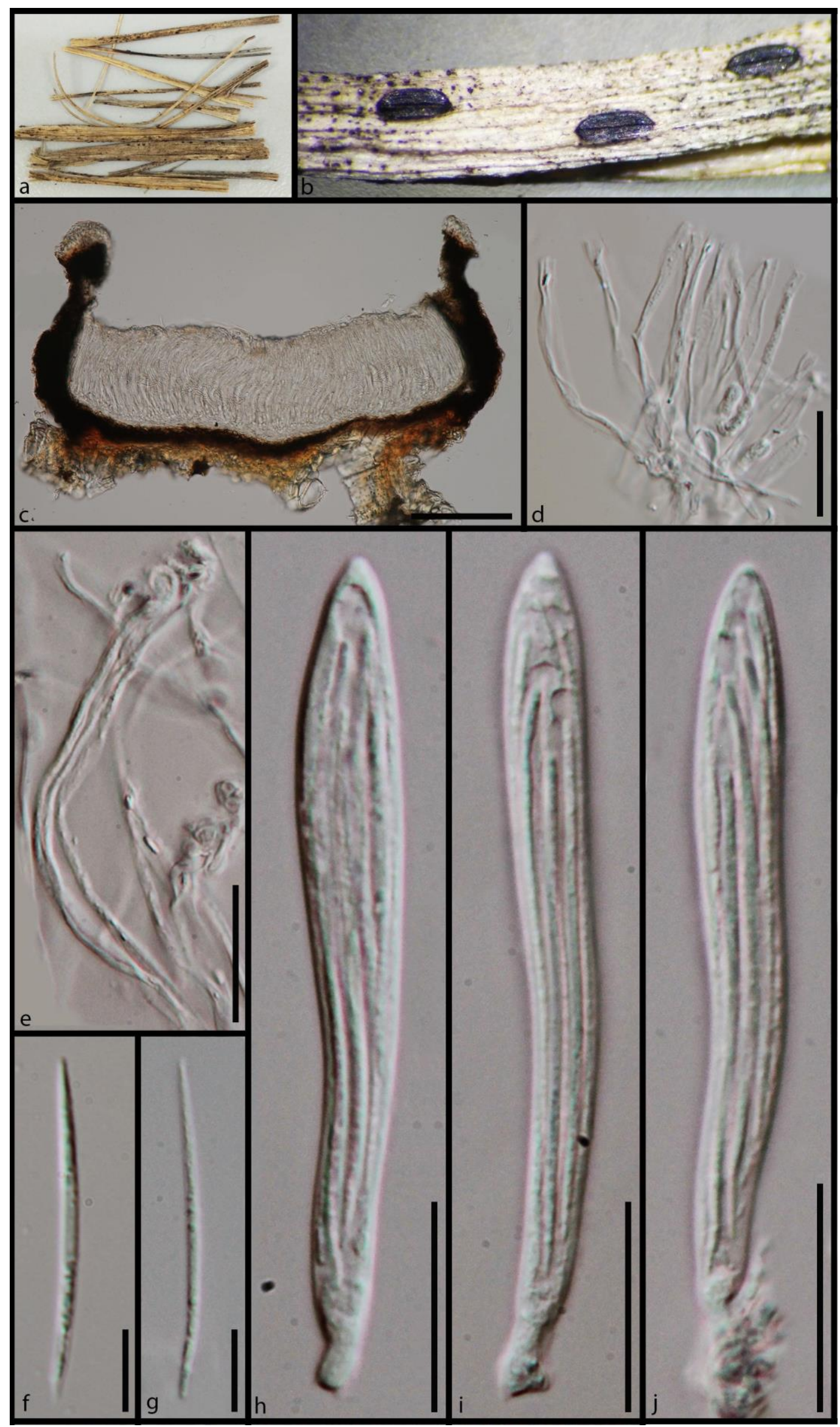

Figure 63 - Morphology of Lophodermium herbarum (MFLU 15-3182) a Substrate. b Apothecia on wood. c Cross section of an apothecium. d, e Filiform paraphyses. f, g Fusoid ascospores. $h-j$ Cylindric-clavate asci. Scale bars: $\mathrm{c}=25 \mu \mathrm{m}, \mathrm{d}, \mathrm{e}=20 \mu \mathrm{m}, \mathrm{f}-\mathrm{g}=10 \mu \mathrm{m}, \mathrm{h}-\mathrm{j}=20 \mu \mathrm{m}$. 


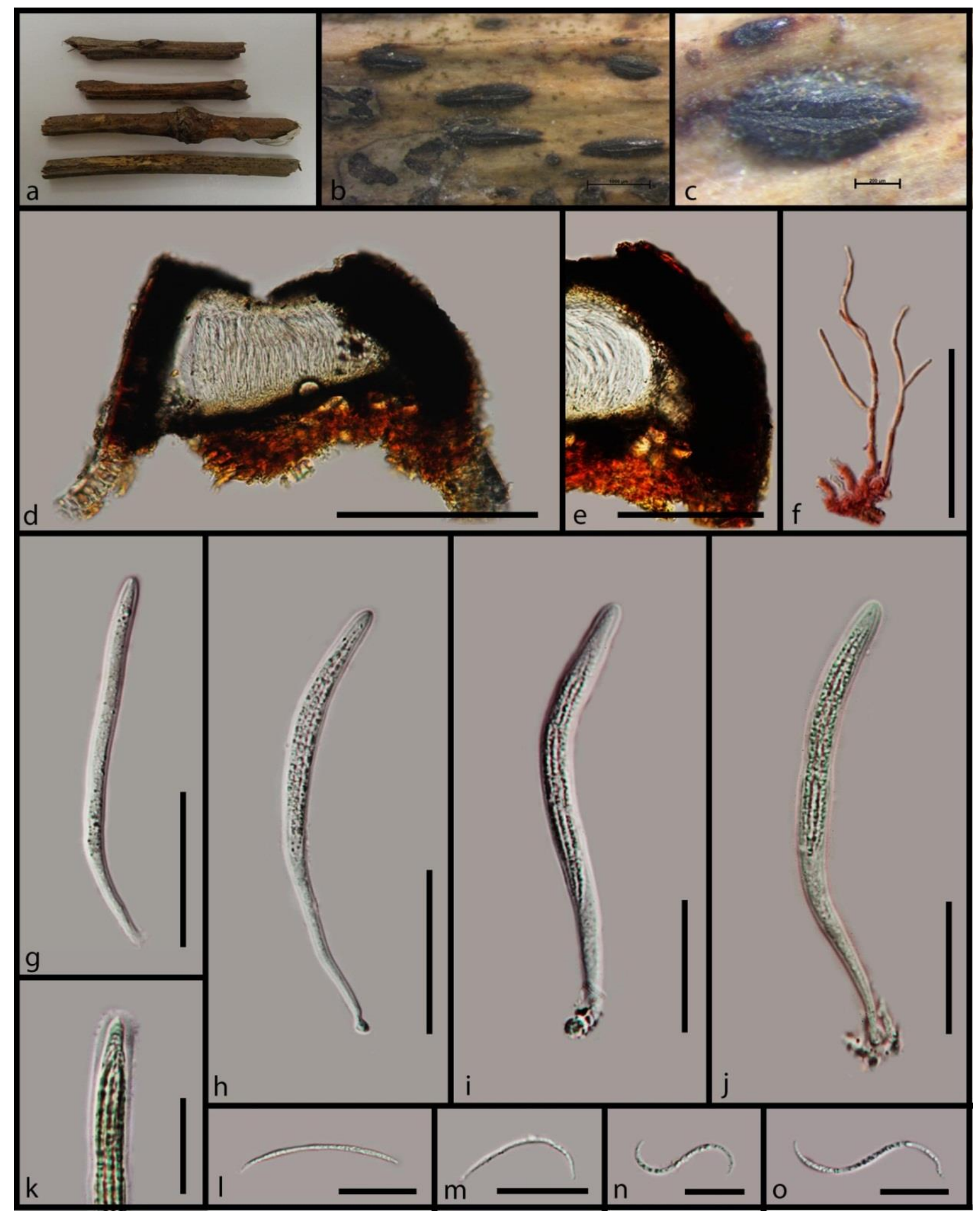

Figure 64 - Morphology of Terriera elliptica (MFLU 16-0582) a Substrate. b, c Apothecia on wood. $d$ Cross section of an apothecium. e Close up of the excipulum. f Filiform paraphyses in congo red. $\mathrm{g}-\mathrm{j}$ Long pedicellate asci. $\mathrm{k}$ Ascus tip. $\mathrm{l}-\mathrm{o}$ Fusoid ascospores. Scale bars: $\mathrm{d}=200 \mu \mathrm{m}$, e $=100 \mu \mathrm{m}, \mathrm{f}=50 \mu \mathrm{m}, \mathrm{g}-\mathrm{j}=35 \mu \mathrm{m}, \mathrm{k}=15 \mu \mathrm{m}, \mathrm{l}-\mathrm{o}=25 \mu \mathrm{m}$. 


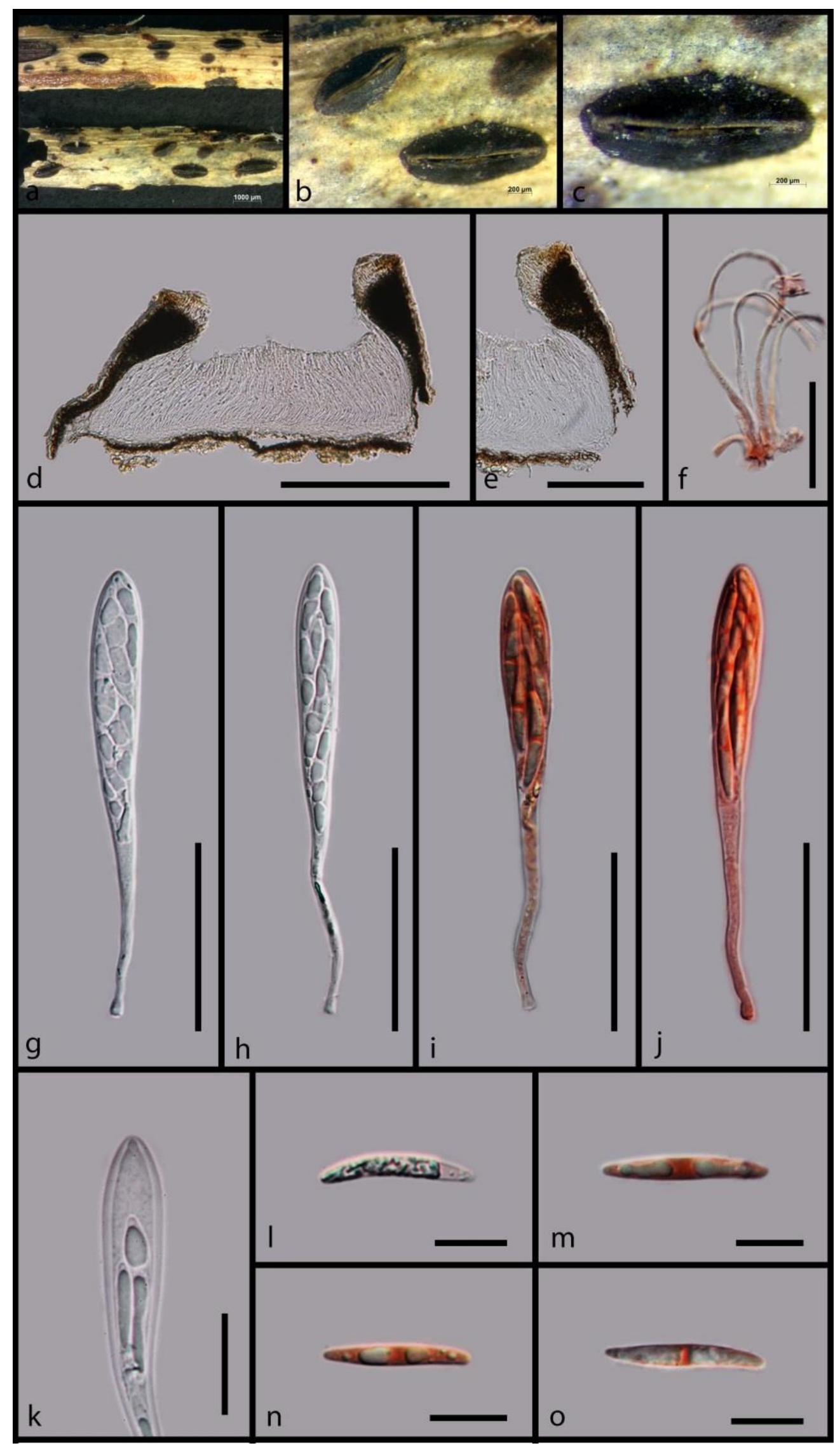

Figure 65 - Morphology of Meloderma sp1 (MFLU 16-0603) a Substrate, b, c Apothecia on wood, $\mathrm{d}$ Cross section of an apothecium, e Close up of the peridium, f Filiform paraphyses in congo red, $\mathrm{g}-\mathrm{j}$ Long pedicellate asci in water and congo red, $\mathrm{k}$ Ascus tip, 1-o Fusoid ascospores in congo red. Scale bars: $\mathrm{d}=200 \mu \mathrm{m}, \mathrm{e}=100 \mu \mathrm{m}, \mathrm{f}=30 \mu \mathrm{m}, \mathrm{g}-\mathrm{j}=40 \mu \mathrm{m}, \mathrm{k}=15 \mu \mathrm{m}, \mathrm{l}-\mathrm{o}=10 \mu \mathrm{m}$. 


\section{Rhytisma acerinum (Pers.) Fr.}

Facesoffungi number: FoF 05951; Fig. 66

Parasitic on living leaves. Sexual morph: Undetermined. Asexual morph: Pycnidia 0.5-1 $\mathrm{mm}$ wide, single or in groups, dark brown to black, immersed. Wall composed of dark brown cells of textura angularis. Conidiogenous cells $10-14 \times 1-2 \mu \mathrm{m}(\bar{x}=12 \times 1.5 \mu \mathrm{m}, \mathrm{n}=20)$, thin, cylindrical, tapering to the apex, hyaline, arising from the inner cell wall of peridium. Conidia 5-8 $\times 1-1.5 \mu \mathrm{m}(\bar{x}=6 \times 1.3 \mu \mathrm{m}, \mathrm{n}=20)$, bacilliform, one side rounded and other side pointed, aseptate, hyaline, produced sympodially from the conidiogenous cell apex.

Material examined - Russia, Rostov region, Shakhty City District, former Shakhtisnskoye forestry, parasitic on living leaves of Acer platanoides L. (Sapindaceae), 1 September 2015, Timur S. Bulgakov, T-943 (MFLU 15-3084).

GenBank accessions - LSU- MK591958, ITS- MK585002, SSU- MK585018

Notes - Our collection is genetically similar to Rhytisma acerinum (Fig. 61) and blast result of ITS sequence of our collection shows $99 \%$ similarity (526/530-99\% with no gaps) with that of $R$. acerinum (isolate- Hou et al. 203) (Hou et al. 2010). The morphology of our collection is also similar to the characteristics provided by Jones (1925) and Minter (2018). However, the conidia are slightly smaller in our collection than the drawing $(8-10 \mu \mathrm{m})$ provided by Minter $(2018)$. We did not observe the sexual morph of $R$. acerinum.

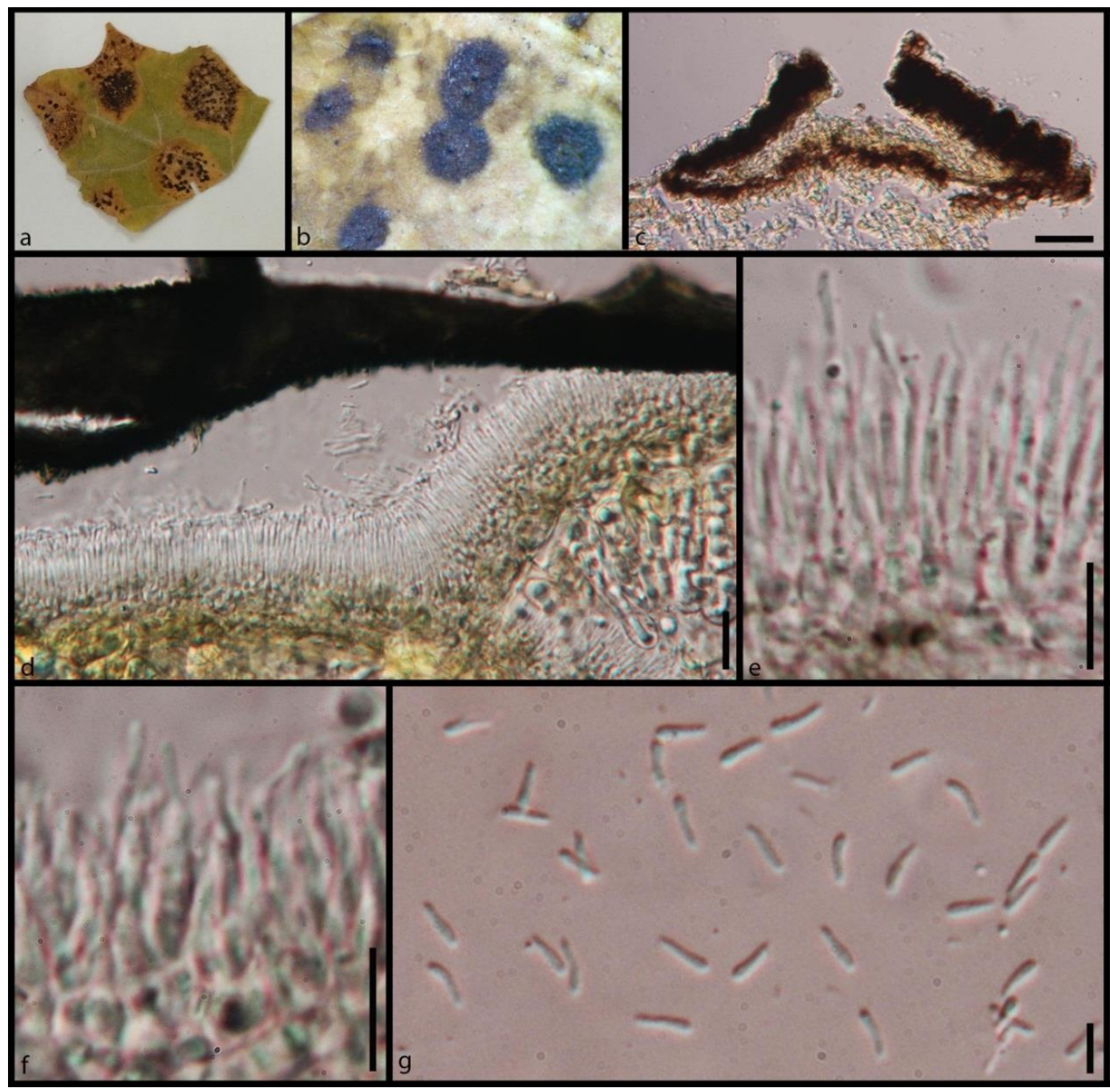

Figure 66 - Morphology of Rhytisma acerinum (MFLU 15-3084) a Substrate. b Conidiomata on substrate. c Cross section of conidioma. d Close up of cross section of conidioma at the margin. e, $\mathrm{f}$ Different stages of conidiogenesis. g Conidia. Scale bars: $\mathrm{c}=30 \mu \mathrm{m}, \mathrm{d}=15, \mathrm{e}, \mathrm{f}=10 \mu \mathrm{m}, \mathrm{g}=5$ $\mu \mathrm{m}$. 


\section{"SCLEROTINIALES"}

The families included in this clade (Sclerotiniaceae, Hemiphacidiaceae, Cenangiaceae Rutstroemiaceae and Chlorociboriaceae) were previously classified under Helotiales. Pärtel (2016) also suggested this as a monophyletic group separate from other Helotiales.

\section{Hemiphacidiaceae Korf}

Facesoffungi number: FoF 05952

Taxa are saprobic, plant parasitic or rarely endoparasitic on nematodes (Jansson et al. 1984, Korf 1962, Pärtel et al. 2017). Ascomata are apothecial. Apothecia are discoid to cupulate, sessile or stipitate, sometimes immersed in host tissue and opening by a lid or transversal cracks of the overlying host tissue. The margin and exterior surface are smooth or sometimes tomentose to pustulate by hyaline to brown hair-like elements. The ectal excipulum is reduced or composed of cells of hyaline to brown textura globulosa-angularis or textura prismatica and medullary excipulum is composed of cells of textura angularis or textura intricata. Paraphyses are cylindrical or lanceolate and sometimes slightly swollen at the apices. Asci are 2-8-spored, amyloid or nonamyloid and sometimes arising from croziers. Ascospores are ellipsoid, fusoid, clavate or allantoid, 0-1-septate, hyaline or brown, sometimes with sheath and sometimes form microconidia by budding (Korf 1962, Corner 1930, Gernandt et al. 2001, Hein 1983, Stone \& Gernandt 2005, Tedersoo et al. 2009, Verkley 1995, Wang et al. 2006a, Zhuang et al. 2010, Jaklitsch et al. 2016, Stoykov \& Assyov 2009, Chalkley 2018, Ren \& Zhuang 2014a, Baral \& Peric 2014, Perić et al. 2015). Asexual morphs are hyphomycetous, acervular or sporodochial. Conidiogenesis is holoblastic or phialidic. Conidia are aseptate or staurosporous and micro- and macroconidial (Jaklitsch et al. 2016).

Notes - This family was previously synonymized with Cenangiaceae, but we observed a separate clade for this family. The same phylogenetic position was also shown by Pärtel et al. (2017). Therefore, we reintroduce the family within "Sclerotiniales".

\section{Sclerotiniaceae Whetzel ex Whetzel}

Facesoffungi number: FoF 05953

Taxa are saprobic or plant parasitic. Ascomata are apothecial. Apothecia are cupulate to plane or pileate, stipitate and usually emerge from sclerotia. The ectal excipulum is composed of cells of textura globulosa or textura prismatica and medullary excipulum is composed of cells of textura prismatica, textura intricata or loosely arranged hyphae. Paraphyses are filiform, cylindrical and hyaline. Asci are 2-8-spored, amyloid, rarely non-amyloid and sometimes arising from croziers. Ascospores are ellipsoid, rarely fusoid or allantoid, smooth, hyaline, rarely warted, guttulate, often with sheath, 1-3-septate and form microconidia by budding (Saito \& Kaji 2006, Fuhrer \& May 1993, Beaton \& Weste 1984, Hosoya et al. 2014, Salgado-Salazar et al. 2018, Andrew et al. 2012, Batra 1991, Holst-Jensen et al. 1997, Hustad \& Miller 2011, Kohn \& Nagasawa 1984, Schumacher \& Holst-Jensen 1997, Schumacher \& Kohn 1985, Spooner 1987, Verkley 1993, Livsey \& Minter 1994). Asexual morphs are hyphomycetous, acervular or pycnidial. Conidiogenesis is holoblastic and phialidic. Conidia are aseptate hyaline, rod-shape and smooth (Jaklitsch et al. 2016, Livsey \& Minter 1994).

Notes - This family includes plant parasites and phylogenetically formed a monophyletic clade sister to Rutstroemiaceae. Some taxa are pathogens on various mono and dicots stems, leaves, flowers, fruits, seeds and wood, which cause stem cankers, flower blight and fruit and leaf spots (Navaud et al. 2018). This family also includes mould pathogens such as the grey mould pathogen Botrytis cinerea, which consider as one of the ten most devastating plant pathogens (Dean et al. 2012).

Rutstroemiaceae Holst-Jensen, L.M. Kohn \& T. Schumach.

Facesoffungi number: FoF 05954 
Taxa are saprobic or fungicolous. Ascomata are apothecial, rarely cleistothecial. Apothecia are cupulate to discoid, stipitate. The margin and exterior surface are smooth or sometimes with hairs. Hairs are cylindrical, septate and mostly hyaline. The ectal excipulum is composed of cells of textura prismatica or textura globulosa and medullary excipulum is composed of cells of textura intricata. Paraphyses are cylindrical. Asci are 8-spored, cylindric-clavate, amyloid, rarely nonamyloid and sometimes arising from croziers. Ascospores are ellipsoid to allantoid, hyaline, 0-4septate and form microconidia by budding (Zhao et al. 2013, 2016, Zhuang 1988, Nannfeldt 1936, Jaklitsch et al. 2016, Spooner 1987). Cleistothecia are characterized by sub-globose shape and peridium composed of cells of textura angularis and evanescent asci (Galán et al. 2015). Asexual morphs are hyphomycetous and phialidic (Jaklitsch et al. 2016).

Notes - This family includes apothecial ascomata except for the genus Bicornispora (Galán et al. 2015). The family forms a monophyletic clade between Cenangiaceae and Sclerotiniaceae.

\section{Cenangiaceae Rehm}

Facesoffungi number: FoF 05955

Taxa are saprobic. Ascomata are apothecial and characterized by sessile or short-stipitate, cupulate to discoid receptacle. The ectal excipulum is composed of cells of textura angularis to globulosa and medullary excipulum is composed of cells of textura intricata. Paraphyses are filiform, septate and slightly swollen at the apex. Asci are 8-spored, cylindric-clavate, amyloid and sometimes arising from croziers. Ascospores are globose, ellipsoid to fusoid, 0-2-septate, and hyaline (Singhr \& Tewari 1977, Johnston 2002, Kunca \& Leontovyč 2013). Asexual morphs are pycnidia, conidiogenesis is phialidic and conidia are aseptate, hyaline, and staminate (Kunca \& Leontovyč 2013).

Notes - The family Hemiphacidiaceae formed a monophyletic clade within "Sclerotiniales" clade.

\section{Neolauriomycetaceae Crous}

Facesoffungi number: FoF 05956

Taxa are saprobic. Sexual morphs are not recorded. Asexual morphs are hyphomycetous. Conidiophores are solitary, subcylindrical, straight or slightly flexuous, unbranched, brownish, smooth, septate and branched. Conidiogenesis is phialidic and conidia are fusiform to drop-shaped or ampulliform, hyaline to brownish, smooth and including the apical collarette (Réblová et al. 2011, Crous et al. 2018).

Notes - In our phylogenetic analysis this family formed a monophyletic clade sister to Chlorociboriaceae. The family includes saprobic, hyphomycete genera.

Chlorociboriaceae Baral \& P.R.Johnst.

Facesoffungi number: FoF 05957

Taxa are saprobic on dead stems. Ascomata are apothecial. Apothecia are stipitate, cupulate to discoid, arising from a basal stromatic mass, erumpent or superficial and blue green. The exterior surface is glabrous or with short septate hairs. The ectal excipulum is composed of cells of textura prismatica or textura intricata and covered by dark green exudate and medullary excipulum is composed of cells of textura intricata. Paraphyses are filiform. Asci are 8-spored, arising from croziers and cylindric-clavate with amyloid ring. Ascospores are ellipsoid to fusoid, straight to slightly curved, hyaline and 0-3-septate (Johnston \& Park 2005, Donner et al. 2012, Robinson 2012, Robinson et al. 2012, 2014, Ren \& Zhuang 2014b, Zheng \& Zhuang 2017b). Asexual morphs are stromatic and multilocular and conidia are rod-shaped (Jaklitsch et al. 2016).

Notes - Chlorociboria species are economically important as they produce green stain, named xylindein (Edwards \& Kale 1965, Saikawa et al. 2000, Donner et al. 2012). 


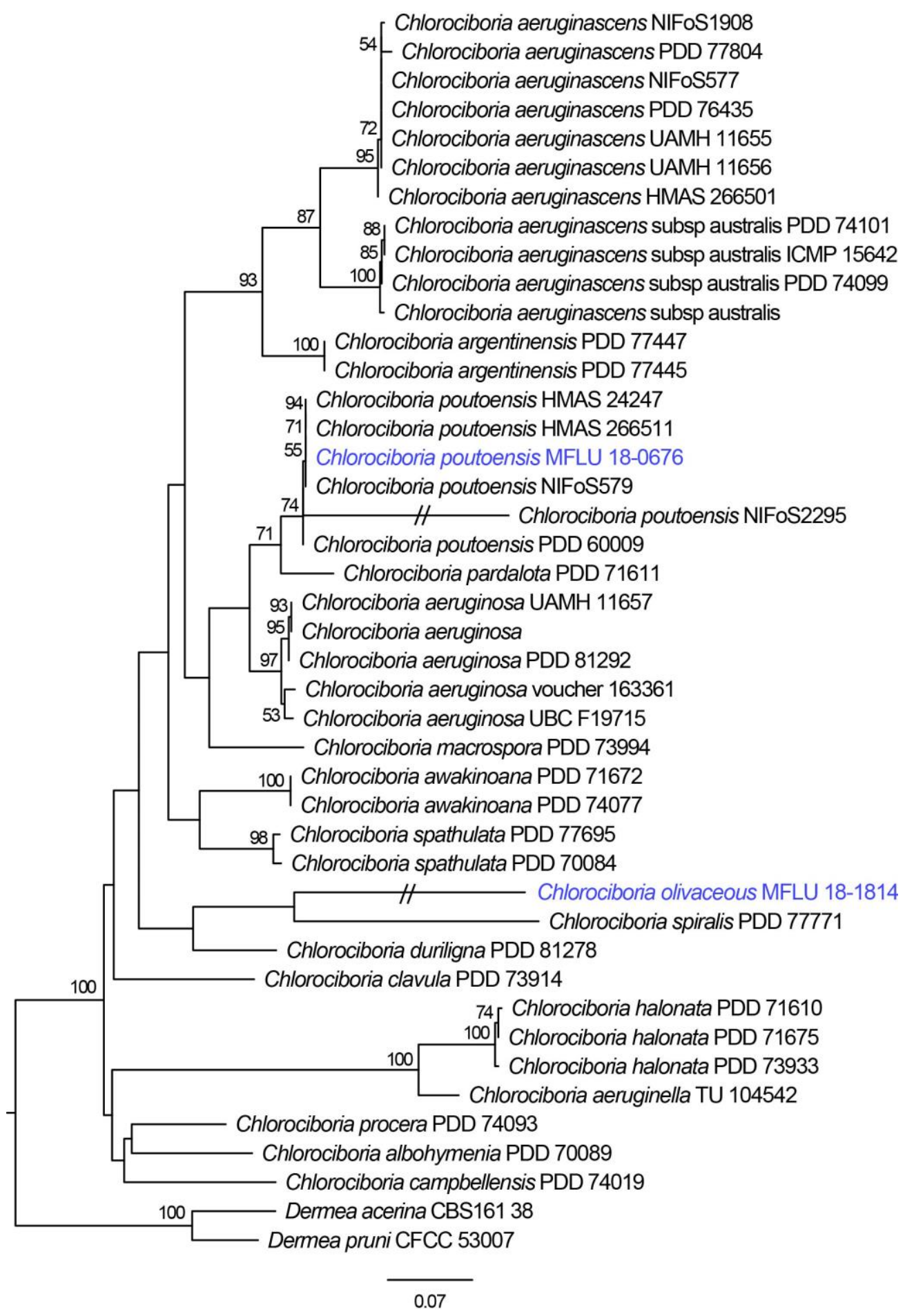

Figure 67 - Phylogram generated from maximum likelihood analysis of sequences of Chlorociboria based on ITS sequence data. MLBP values $\geq 50 \%$ are given near the nodes. Strain/culture numbers are given after the taxon names. The tree is rooted with Dermea acerina (CBS161 38) and Dermea pruni (CFCC 53007).

Chlorociboria olivaceous Ekanayaka \& K.D. Hyde, sp. nov.

Index Fungorum number: IF556305; Facesoffungi number: FoF 05958; Fig. 68

Etymology - refers to the colour of apothecial disc

Holotype - MFLU 18-1814

Saprobic on dead stems. Sexual morph: Apothecia 2-3 $\times 1-2 \mathrm{~mm}$, arising in clusters, stipitate. Receptacle cupulate, bluish green to yellowish or olive green. Margins concolorous to receptacle, inrolled towards the disc. Disc concave, yellowish green. Ectal excipulum $25-35 \mu \mathrm{m}(\bar{x}$ 
$=27 \mu \mathrm{m}, \mathrm{n}=10$ ) in lower flanks, composed of thin-walled cells of textura angularis to globulosa, two layers, cells in outer layer are green and inner layer is hyaline. Medullary excipulum 80-120 $\mu \mathrm{m}(\bar{x}=95 \mu \mathrm{m}, \mathrm{n}=10)$ in lower flanks, composed of, thin-walled, hyaline cells of textura intricata. Hymenium hyaline. Paraphyses $1.6-2.3 \mu \mathrm{m}$ wide $(\bar{x}=1.8 \mu \mathrm{m}, \mathrm{n}=20)$, numerous, filiform, obtuse at the apex, aseptate, exceeding the asci in length, smooth, apices covered with greenish gelatinous material. Asci 50-75 $\times 4-5.5 \mu \mathrm{m}(\bar{x}=63 \times 4.5 \mu \mathrm{m}, \mathrm{n}=30)$, 8-spored, unitunicate, cylindrical, rounded at the apex, faintly amyloid apex, stipitate base. Ascospores 4.5-5 $\times 2.5-3 \mu \mathrm{m}(\bar{x}=4.8 \times 2.7 \mu \mathrm{m}, \mathrm{n}=40), 1$-seriate, ellipsoid to ovoid, aseptate, hyaline, guttulate. Asexual morph: Undetermined.

Material examined - China, Yunnan Province, Kunming, December 2015, Samantha Karunarathna, NB93 (MFLU 18-1814).

GenBank accessions - LSU- MK592009, ITS- MK584990, TEF- MK714034

Notes - Our collection of NB 93 from China grouped with Chlorociboria spiralis (PDD 77771) with moderate support (Fig. 4). ITS data of our collection is similar to C. spiralis (PDD 77771) (203/228-89\% with 4 gaps) and to C. aeruginosa (voucher 163361) (203/231-88\% with 6 gaps), while the LSU data is similar to $C$. awakinoana (D1549) (768/898-86\% with 17 gaps), $C$. aeruginascens (DSM 107184) (777/921-84 \% with 20 gaps) and C. glauca (KL238) (688/803-86\% with 16 gaps).

Chlorociboria olivaceous is characterized by bluish green to yellowish, cupulate, stipitate apothecia, pigmented ectal excipulum of textura angularis cells, filiform paraphyses covered with greenish gelatinous material, long cylindrical asci and ellipsoid to ovoid ascospores. Chlorociboria olivaceous is phylogenetically close to $C$. spiralis. However, $C$. spiralis differs in having filiform and coiled ascospores (Johnston \& Park 2005).

Chlorociboria poutoensis P.R. Johnst.

Facesoffungi number: FoF 05959; Fig. 69

Saprobic on dead stems. Sexual morph: Apothecia $2-4 \times 1-3 \mathrm{~mm}$, arising singly, stipitate. Receptacle cupulate, greenish blue. Margins concolorous to receptacle. Disc concave, whitish green. Ectal excipulum 35-45 $\mu \mathrm{m}(\bar{x}=40 \mu \mathrm{m}, \mathrm{n}=10)$ in lower flanks, composed of thin-walled, greenish blue cells of textura angularis to prismatica. Medullary excipulum 240-260 $\mu \mathrm{m}(\bar{x}=247$ $\mu \mathrm{m}, \mathrm{n}=10$ ) in lower flanks, composed of thin-walled, hyaline to bluish cells of textura intricata. Hymenium hyaline. Paraphyses $1.2-1.8 \mu \mathrm{m}$ wide $(\bar{x}=1.5 \mu \mathrm{m}, \mathrm{n}=20)$, numerous, filiform, obtuse, aseptate, exceeding the asci in length, smooth, guttulate. Asci $90-100 \times 6.8-7.2 \mu \mathrm{m}(\bar{x}=93 \times 6.9$ $\mu \mathrm{m}, \mathrm{n}=30$ ), 8-spored, unitunicate, cylindrical, apex rounded and amyloid, base stipitate. Ascospores 10-15 $\times 3.5-4 \mu \mathrm{m}(\bar{x}=12.5 \times 3.7 \mu \mathrm{m}, \mathrm{n}=40), 1-2$-seriate, ellipsoid to fusoid, aseptate, hyaline, guttulate and with slightly tapered ends. Asexual morph: Undetermined.

Material examined - Thailand, Chiang Mai Province, Mushroom Research Center, August 2017, A.H. Ekanayaka, HD59 (MFLU 18-0676).

GenBank accessions - LSU- MK591994, ITS- MK584968, SSU- MK585041, TEFMK714025, RPB2- MK614725

Notes - Our collection HD59 from Thailand grouped within Chlorociboria poutoensis clade and the clade received 74\% statistical support (Fig. 67). The ITS data of our collection is similar to C. poutoensis strains HMAS 24247 (505/507-99\% with 2 gaps) and HMAS 266511 (505/508-99\% with 3 gaps), while the LSU data is similar to C. poutoensis (HMAS 266511) (589/593-99\% with 1 gap) and to $C$. cf. aeruginosa (OSC 100056) (582/594-98\% with 2 gaps).

Chlorociboria poutoensis is characterized by blue green, cupulate, stipitate apothecia, pigmented ectal excipulum of textura angularis to textura prismatica cells, filiform paraphyses, long cylindrical asci and ellipsoid to fusoid ascospores. Morphology of our collection agrees with the description of C. poutoensis by Johnston \& Park (2005). 


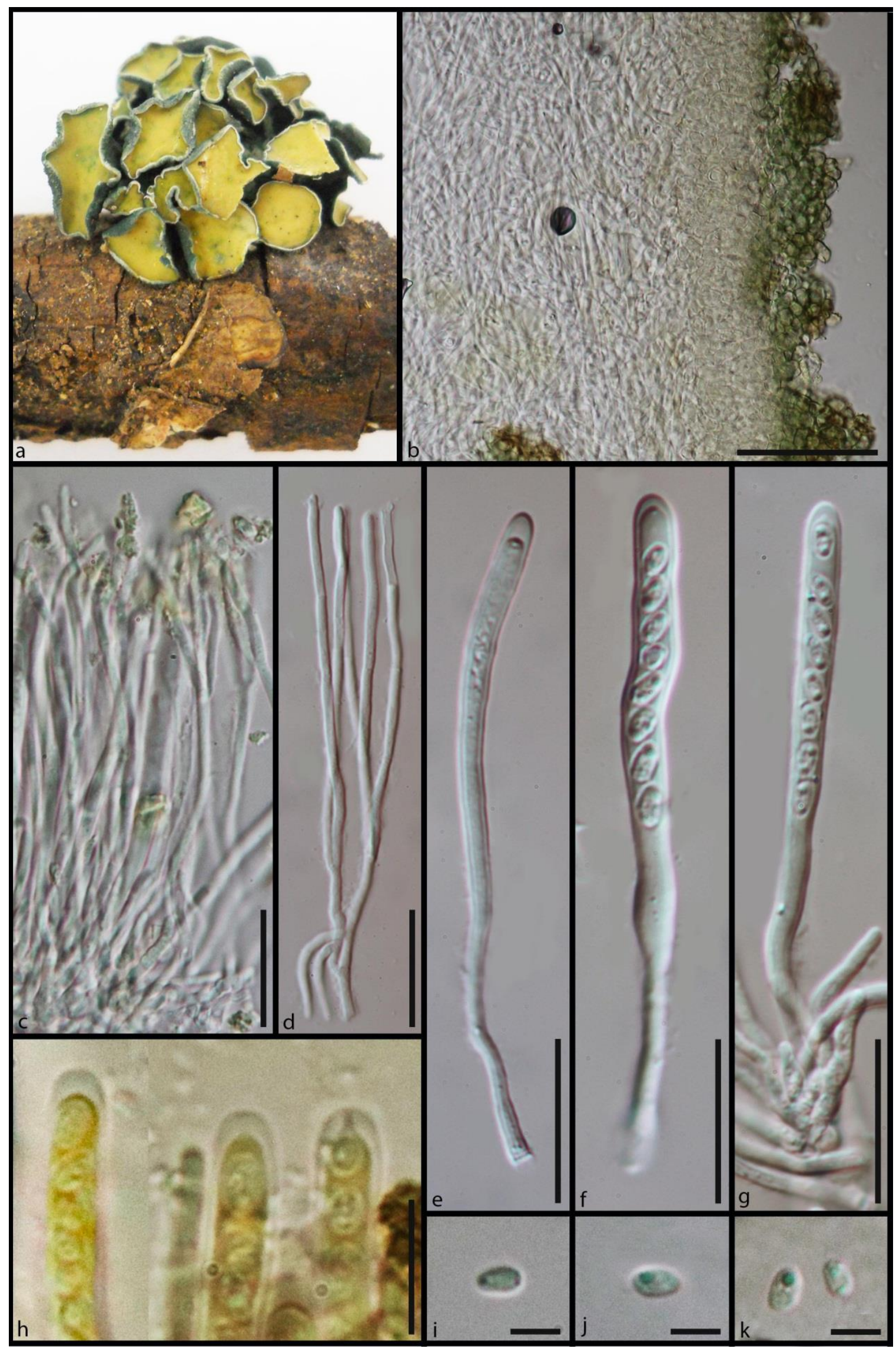

Figure 68 - Morphology of Chlorociboria olivaceous (MFLU 18-1814 holotype) a Apothecia on wood. b Close up of excipulum at flanks. c, d Filiform paraphyses. e-g Cylindrical asci. h Apices of amyloid asci in Melzer's reagent. i-k Ellipsoid ascospores. Scale bars: $b=30 \mu \mathrm{m}, \mathrm{c}, \mathrm{d}=25 \mu \mathrm{m}$, $\mathrm{e}-\mathrm{g}=20 \mu \mathrm{m}, \mathrm{h}=10 \mu \mathrm{m}, \mathrm{i}-\mathrm{k}=5 \mu \mathrm{m}$. 


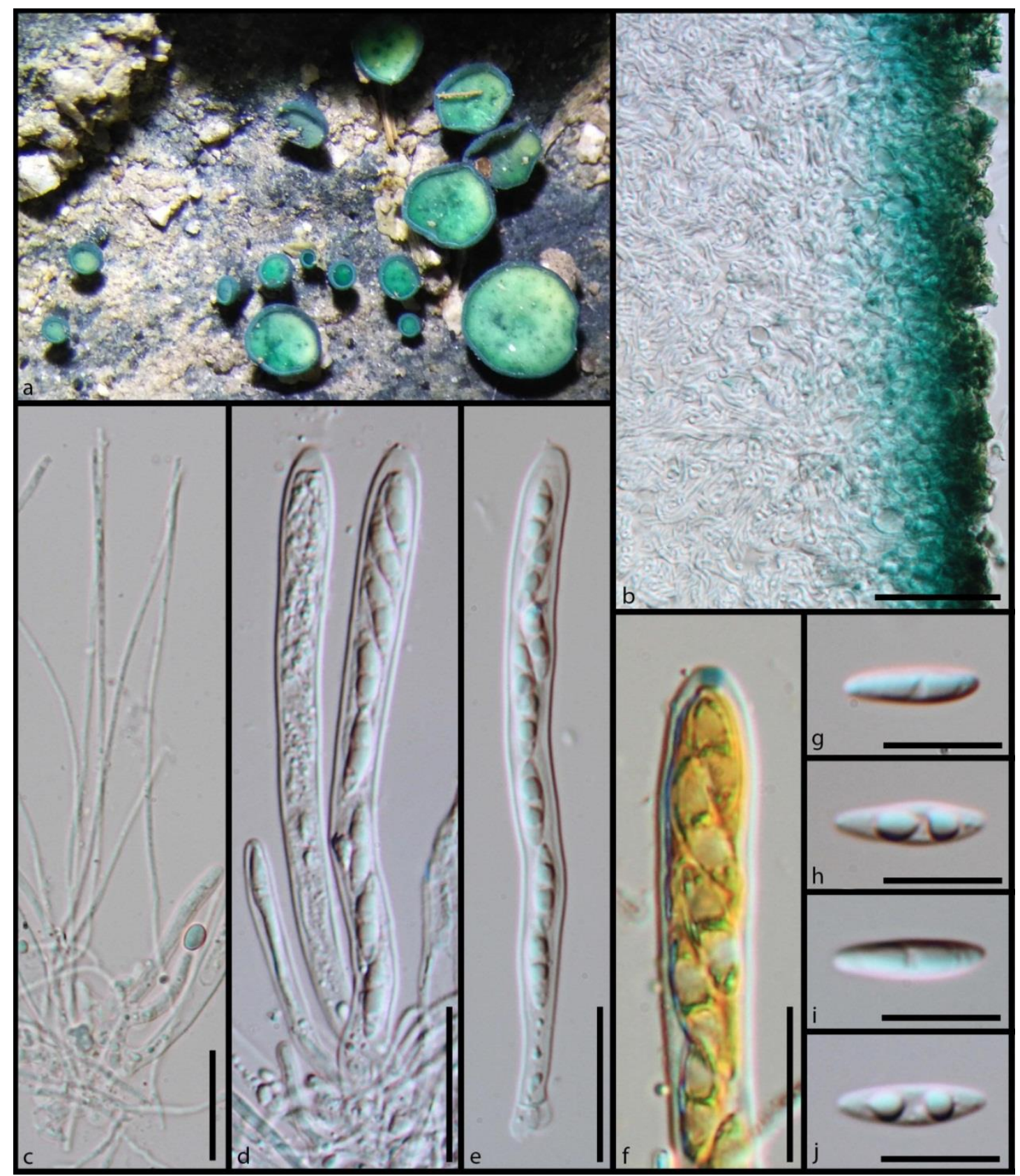

Figure 69 - Morphology of Chlorociboria poutoensis (MFLU 18-0676) a Substrate. b Close up of the excipulum at flanks. c Filiform paraphyses. d, e Cylindrical asci. f Amyloid ascus apex. g-j Fusoid ascospores. Scale bars: $\mathrm{b}=40 \mu \mathrm{m}, \mathrm{c}=15 \mu \mathrm{m}, \mathrm{d}, \mathrm{e}=20 \mu \mathrm{m}, \mathrm{f}=15 \mu \mathrm{m}, \mathrm{g}-\mathrm{j}=10 \mu \mathrm{m}$.

\section{THELEBOLALES}

This order was introduced by Haeckel (1894). Taxa include small translucent apothecia, mostly coprophilous. In our analysis it forms a monophyletic clade sister to Lichinodiales.

\section{Thelebolaceae Engl.}

= Pseudeurotiaceae Malloch \& Cain

Facesoffungi number: FoF 05960

Taxa are saprobic on dead plant material or herbivore dung, rarely plant parasitic. Asomata are absent, apothecial or cleistothecial. When ascomata absent, asci formed directly on fertile hyphae without an exciple, paraphyses are absent, asci are 8-spored, sessile, subglobose to ellipsoidal and arising from croziers and ascospores are ellipsoid to fusiform and hyaline (Stchigel et al. 2001, de Menezes et al. 2017, Brummelen 1985). Apothecia are turbinate, cylindrical, 
obconical, pulvinate, or cupulate, sessile and glabrous or with thin-walled, tapering hairs. The ectal excipulum is composed of cells of textura globulosa-angularis, textura prismatica or textura porrecta and medullary excipulum is composed of cells of textura porrecta. Paraphyses are filiform, sometimes apically swollen, straight to slightly curved and septate. Asci are 4-1000spored, clavate to subglobose or broadly cylindrical, non-amyloid, opening by rupturing or operculum and sometimes arising from croziers. Ascospores are ellipsoid, fusoid to filiform, hyaline, aseptate, rarely septate, sometimes guttulate and smooth-walled or ornamented (Doveri 2007, Brummelen \& Kristiansen 1998, Cain \& Kimbrough 1969, Brummelen 1977, Hoog et al. 2005, Korf \& Abawi 1971, Spegazzini 1887). Cleistothecia are subglobose and covered with appendages. The peridium composed of cells of textura globulosa-angularis. The interscal tissue sometimes absent, when present they are filiform paraphyses. Asci are globose, thin-walled, and evanescent or opening by splitting and some ascomata contain only a few asci or sometimes only a single polysporous ascus. Ascospores are globose to ellipsoid or lunate, aseptate, hyaline, brown and smooth-walled or with longitudinal striations (Malloch \& Cain 1971, Doveri et al. 2013, Rice \& Currah 2006, Sigler et al. 2000, Malloch et al. 2016). Asexual morphs are hyphomycetous, synnematal. Conidiogenesis is phialidic. Conidia are aseptate, hyaline, subglobose to irregularly cylindrical or filiform and smooth (Doveri et al. 2013, Hoog et al. 2005, Korf \& Abawi 1971, Crous et al. 2017, Rice \& Currah 2006, Malloch et al. 2016, Adhikari et al. 2016).

Notes - In our phylogenetic analysis, Pseudeurotiaceae nested within Thelebolaceae. Jaklitsch et al. (2016) also suggested the genetic similarity between these families. Therefore, considering the results of our phylogeny and previous literature, we synonymize Pseudeurotiaceae under Thelebolaceae.

\section{Alatospora- Miniancora clade}

Facesoffungi number: FoF 05989

Taxa are saprobic. Sexual morphs are not recorded. Asexual morphs are hyphomycetous, producing long conidiophores, conidiogenesis is phialidic and conidia are tetraradiate, T-shaped or flail-shaped, main axis filiform and septate with 0-4 branches (Fiuza et al. 2017, Fiuza \& Gusmão 2013, Baschien et al. 2013).

Notes - This clade includes the genera previously classified under Leotiaceae and Leotiomycetes genera incertae sedis. They are mostly found in aquatic habitats (Baschien et al. 2013).

\section{TRIBLIDIALES}

This order was introduced by Eriksson (1992) and was previously placed in Ostropales (Lecanoromycetes) (Magnes 1997). Jaklitsch et al. (2016) placed it within Leotiomycetes considering its morphological characters.

\section{Triblidiaceae Rehm}

Facesoffungi number: FoF 05961

Taxa are saprobic on dead plant material (Magnes 1997). Ascomata are apothecial. Apothecia are discoid or hysterioid, sessile or sub-stipitate, closed when immature and opening by a split or radial fissures at maturity. The ectal excipulum is composed of cells of heavily melanized textura angularis. Paraphyses are apically slightly swollen, branched, hyaline and guttulate. Asci are 4-8spored, cylindric-clavate, non-amyloid and arising from croziers. Ascospores are ellipsoid to fusiform, dictyo- to phragmosporous or muriform, thick-walled, smooth or warted and multiguttulate (Magnes 1997, Jaklitsch et al. 2016). Asexual morphs are not recorded.

Notes - This family does not have any available sequence data. Therefore, we are unable to provide a stable phylogenetic position for this family and keep it under Leotiomycetes incertae sedis following Jaklitsch et al. (2016). 


\section{TRIZODIA-CALLORIOPSIS CLADE}

This clade includes two subclades Trizodia clade and Corticifraga-Calloriopsis clade.

\section{Trizodia clade}

Facesoffungi number: FoF 05962

Taxa are saprobic. Ascomata are apothecial and characterised by sessile to short-stipitate, subglobose or turbinate receptacle. The ectal excipulum is composed of cells of textura porrecta and medullary excipulum is not clear. Paraphyses are filiform and septate. Asci are 8-spored, clavate, often with a long and narrow base, arising from croziers and amyloid. Ascospores are ellipsoid to ovate to pyriform, smooth, one-celled and with one large or several small oil droplets (Stenroos et al. 2010). Asexual morphs are not recorded.

Notes - This genus formed a basal clade sister to Chaetomellales as also reported by Stenroos et al. (2010).

\section{Corticifraga-Calloriopsis clade}

Facesoffungi number: FoF 05990

Taxa are mainly lichenicolous and sometimes saprobic. Ascomata are apothecial and characterised by sessile or sub-stipitate, cupulate, globose or pulvinate receptacle, sometimes gelatinous and sometimes developed within host and opening by splitting into irregular lobes. The ectal excipulum is reduced or composed of cells of textura prismatic-angular or globulosa and medullary excipulum is composed of textura prismatica or loosely arranged hyphae. The hymenium is gelatinized or not. Paraphyses are filiform, apically slightly swollen, septate and unbranched or very rarely branched. Asci are 4-8-spored, clavate or globose, sometimes bitunicate, non-amyloid and sometimes with small ocular chamber. Ascospores are hyaline, ellipsoid to fusoid or bacilliform, septate and sometimes form ascoconidia by budding (Spribille et al. 2010, Zhurbenko 2007, Baral \& Marson 2001, Pfister 1976). Asexual morphs are hyphomycetous. Conidiophores are semimacronematous, mononematous, septate and unbranched. Conidiogenous cells are integrated and holoblastic. Conidia are distinctly irregularly globose and formed by branched and loosely spirally interwoven filaments (Voglmayr 2004).

Notes - Calloriopsis was previously classified under Helicogoniaceae and Corticifraga and Spirosphaera under Helotiales, genera incertae sedis. Sexual morphs are recorded only for Corticifraga and Calloriopsis and asexual morphs are only known for Spirosphaera. We observed a close phylogenetic relationship between these three genera that formed a monophyletic clade sister to Trizodia clade.

\section{Discussion}

Class Leotiomycetes comprises the inoperculate discomycetes, although it also includes some operculate and non-apothecial taxa (Brummelen \& Kristiansen 1998, Cain \& Kimbrough 1969, Brummelen 1977). This paper outlines the families of Leotiomycetes based on known information from the literature and morphological and molecular data from fresh collections. Hence our study provides a natural classification for Leotiomycetes to the family-level which may be modified by the addition of new data in the future.

Even though Leotiomycetes taxa have a wide geographical distribution, most are recorded from the Northern Hemisphere and temperate regions. For example, many taxa in Stamnaria, Medeolariaceae, Ascocorticiaceae, and Sclerotiniaceae are plant pathogens and Mitrulaceae includes saprobes, and these fungi might have evolved primarily in the Northern Hemisphere (LoBuglio \& Pfister 2010, Jaklitsch et al. 2016, Wang et al. 2006a, b). However, Cyttaria spp. and Chlorovibrissea spp. are only found in the Southern Hemisphere (Peterson \& Pfister 2010, Peterson et al. 2010, Kohn 1989, Sandoval-Leiva et al. 2014). The genera such as Chlorociboria have a higher diversity in Asian/Australasian locations (Johnston \& Park 2005).

Many Leotiomycetes taxa are only known from either their sexual or asexual stages (Ekanayaka et al. 2017), and confirmation of links between sexual and asexual morphs in 
Leotiomycetes is little known (Sati \& Pathak 2016, Sutton \& Hennebert 1995, Ekanayaka et al. 2017). Many studies have shown that fungi from various environmental samples including soil, root and leaf endophytes belong to Leotiomycetes (Arnold et al. 2007, Arnold \& Lutzoni 2007, Herrera et al. 2010, Higgins et al. 2011, Napoli et al. 2010, Seephueak et al. 2010, Soca-Chafre et al. 2011, U'Ren et al. 2010). However, there are often no clear sexual-asexual morph connections. Most aquatic asexual taxa are phylogenetically related to Leotiomycetes (Campbell et al. 2009, Pascoal et al. 2005, Marvanova et al. 1997, Sri-indrasutdhi et al. 2015, Baschien et al. 2013). Many Leotiomycetes cannot be cultured easily under laboratory conditions (McLaughlin \& Spatafora 2015), thus proving difficult to undertake studies within this class.

The greatest challenge to provide a natural classification for the Leotiomycetes is the lack of sequence data for many taxa. Although ITS and LSU sequence data are available in GenBank for many of the genera, SSU, TEF and RPB2 gene regions are comparatively poorly represented. We provide more than 250 new sequences for 51 Leotiomycetes species that helps to resolve the identification of many taxa and is leading to a more natural classification.

The current study identified nine new families (Hamatocanthoscyphaceae, Hyphodiscaceae, Deltopyxidaceae, Amicodiscaceae, Chlorospleniaceae, Discinellaceae, Bryoglossaceae, Hydrocinaceae and Solenopeziaceae) and 14 new family-level clades (Trizodia clade, CorticifragaCalloriopsis clade, Micraspis clade, Flagellospora clade, Gelatinomyces clade, EpicladoniaEpithamnolia clade, Alatospora- Miniancora clade, Coleophoma-Parafabraea clade, Aquapoterium-Unguicularia clade, Patellariopsis clade, Phialocephala urceolata clade, Peltigeromyces clade, Bulgariella clade and Colipila clade) within Leotiomycetes.

We also introduced six new genera and 22 new species belonging to the families Cordieritidaceae, Chlorociboriaceae, Helotiaceae, Lachnaceae, Calloriaceae, Loramycetaceae, Ploettnerulaceae, Vibrisseaceae, Godroniaceae, Dermateaceae, Leptodontidiaceae, Phacidiaceae, Rhytismataceae and Pezizellaceae.

We have not included some genera, such as Sclerotia, Coma, Phacidiella, Leohumicola, Trullula, and Mycosymbioces, previously assigned to the Leotiomycetes, as our preliminary phylogenetic study (data not shown) showed they did not group in the class and are phylogenetically related to non-Leotiomycetes taxa.

According to our phylogenetic analysis there are 19 clades within Leotiomycetes, but the statistical support for those clades are relatively low. More sequence data from various Leotiomycetes taxa are required to stabilize these clades and sub-clades, and also other gene regions need to be selected to develop a more robust classification. Many genera were shown to be highly polyphyletic (e.g. Lachnum, Hyalopeziza, Mollisia, Pyrenopeziza, Lophodermium and Coccomyces) as also indicated by other studies (Li et al. 2016, Hosoya et al. 2010). Many Leotiomycetes genera lack type specimens in good condition and often have poor morphological descriptions. Therefore, these taxa are need to be recollected to establish a better resolved natural classification for the Leotiomycetes. Detailed monographs of genera are required to identify generic delineations. Furthermore, ranking of Leotiomycetes with evidence from molecular clock analyses (as in Hyde et al. 2017) is required.

\section{Acknowledgements}

This study was supported by the National Natural Science Foundation of China (No. 31360015) and the CAS/SAFEA International Partnership Program for Creative Research Teams, and the Knowledge Innovation Program of the Chinese Academy of Sciences (No. KSCX2-EW-Z9 KIB2016002). Kevin D. Hyde would like to thank the Thailand Research Funds entitled Impact of climate change on fungal diversity and biogeography in the Greater Mekong Subregion (grant no: RDG6130001). Prof. Gareth Jones is thanked for his kind guidance and continuous support during the study. Shi-ke Huang Zeng Ming and JungFu Li are thanked for the support during collecting samples and arranging molecular data. Anusha H. Ekanayaka is grateful to Mr. W. Ekanayaka (deceased), Mrs. C. Ekanayaka and Mr. A. Surasinghe for their valuable support and encouragement. 


\section{References}

Adhikari M, Kim S, Kim HS, Lee HB et al. 2016 - Sixteen New Records of Ascomycetes from Crop Field Soil in Korea. Korean Journal of Mycology 44, 271-288.

Almeida DA, Santa-Izabel TD, Gusmão LF, Castañeda-Ruíz RF. 2015 - A new species of Diplococcium from the Brazilian semi-arid region. Mycotaxon 130, 495-498.

Alstrup V, Hawksworth DL. 1990 - The lichenicolous fungi of Greenland. Meddelelser om Grønland Biosciences 31, 1-90.

Andrew M, Barua R, Short SM, Kohn LM. 2012 - Evidence for a common toolbox based on necrotrophy in a fungal lineage spanning necrotrophs, biotrophs, endophytes, host generalists and specialists. PLoS ONE 7, e29943.

Arnold AE, Henk DA, Eells RL, Lutzoni F, Vilgalys R. 2007 - Diversity and phylogenetic affinities of foliar fungal endophytes in loblolly pine inferred by culturing and environmental PCR. Mycologia 99, 185-206.

Arnold AE, Lutzoni F. 2007 - Diversity and host range of foliar fungal endophytes: are tropical leaves biodiversity hotspots? Ecology 88, 541-549.

Arx JA von. 1971 - On Arachniotus and related genera of the Gymnoascaceae. Persoonia 6, 371380.

Ashrafi S, Knapp DG, Blaudez D, Chalot M et al. 2018 - Inhabiting plant roots, nematodes and truffles - Polyphilus, a new helotialean genus with two globally distributed species. Mycologia 110, 286-299.

Baral HO. 1999 - A monograph of Helicogonium (= Myriogonium, Leotiales), a group of nonascocarpous intrahymenial mycoparasites. Nova Hedwigia 69, 1-71.

Baral HO, Marson G. 2001 - Monographic revision of Gelatinopsis and Calloriopsis (Calloriopsideae, Leotiales). Micologia 92, 23-46.

Baral HO, Marson G. 2012 - Deltopyxis triangulispora gen. et sp. nov., a polysporous Tromeropsis-like discomycete of unclear relationship. Andrias 19, 175-183.

Baral HO, Perić B. 2014 - Velutarina bertiscensis and V. alpestris spp. nov., with a redescription of $V$. rufoolivacea and discussion of its synonyms. Mycologia Montenegrina 17, 7-52.

Baral HO, Rämä T. 2015 - Morphological update on Calycina marina (Pezizellaceae, Helotiales, Leotiomycetes), a new combination for Laetinaevia marina. Botanica Marina 58, 523-534.

Baral HO, Haelewaters D. 2015 - Rommelaarsia flavovirens gen. et sp. nov. (Helotiales), a new discomycete on Equisetum with a peculiar asexual state. Ascomycete.org 7, 321-330.

Baral HO, De Sloover JR, Huhtinen SE, Laukka TO, Stenroos SO. 2009 - An emendation of the genus Hyaloscypha to include Fuscoscypha (Hyaloscyphaceae, Helotiales, Ascomycotina). Karstenia 49, 1-17.

Baral HO, Galán R, Platas G, Tena R. 2013a - Phaeohelotium undulatum comb. nov. and Phaeoh. succineoguttulatum sp. nov., two segregates of the Discinella terrestris aggregate found under Eucalyptus in Spain: taxonomy, molecular biology, ecology and distribution. Mycosystema 32, 386-428.

Baral HO, Marson G, Bogale M, Untereiner WA. 2013b - Xerombrophila crystallifera, a new genus and species in the Helotiales. Mycological Research 12, 475-488.

Baral HO, Garcia G, Bogale M, O'Hara MJ, Untereiner WA. 2012 - Colipila, a new genus in the Helotiales. Mycological Progress 11, 201-214.

Baral HO, Haelewaters D, Partel K. 2015 - A new attempt to classify the families of the Helotiales. Poster presented at the Second International Workshop on Ascomycete Systematics, Amsterdam, The Netherlands.

Baschien C, Tsui CKM, Gulis V, Szewzyk U, Marvanova L. 2013 - The molecular phylogeny of aquatic hyphomycetes with affinity to the Leotiomycetes. Fungal Biology 117, 660-672.

Batra LR. 1991 - World species of Monilinia (Fungi): their ecology, biosystematics and control. Matsushima Mycological Memoirs 16: 1-243. 
Beaton G, Weste G. 1976 - Australian discomycetes on dead logs and branches. Transactions of the British Mycological Society 67, 449-454.

Beaton G, Weste G. 1978 - Four inoperculate discomycetes from Victoria, Australia. Transactions of the British Mycological Society 71, 215-221.

Beaton G, Weste G. 1980 - Vibrissea: Two North American species redescribed and a new Javan species. Transactions of the British Mycological Society 75, 243-248.

Beaton G, Weste G. 1983 - A new species of Vibrissea from North Island, New Zealand. New Zealand Journal of Botany 21, 281-283.

Beaton G, Weste G. 1984 - A new species of Banksiamyces on Banksia saxicola (Proteaceae). Transactions of the British Mycological Society 83, 533-535.

Bellemère A. 1968 - Contribution a l'étude du dévelopment de l'apothécie chez les discomycètes inoperculés I. Bulletin de la Société mycologique de France 83, 393-640.

Bergero R, Girlanda M, Bello F, Luppi A, Perotto S. 2003 - Soil persistence and biodiversity of ericoid mycorrhizal fungi in the absence of the host plant in a Mediterranean ecosystem. Mycorrhiza 13, 69-75.

Blackwell M, Hibbett DS, Taylor JW, Spatafora JW. 2006 - Research coordination networks: a phylogeny for kingdom fungi (Deephypha). Mycologia 98, 829-837.

Blechert O, Debener T. 2005 - Morphological characterization of the interaction between Diplocarpon rosae and various rose species. Plant Pathology 54, 82-90.

Braun U. 1981 - Taxonomic studies in the genus Erysiphe. I. Generic delimitation and position in the system of the Erysiphaceae. Nova Hedwigia 34, 679-719.

Brummelen van J. 1977 - A New Genus of Pezizales from Thailand. Kew Bulletin 31, 617-620.

Brummelen van J. 1985 - Pseudoascozonus, a new genus of Pezizales. Proceedings of the Indian Academy of Sciences Section B. 94, 363-367.

Brummelen van J, Kristiansen R. 1998 - Two rare coprophilous ascomycetes from Norway. Persoonia 17, 119-125.

Butin H, Pehl L, De Hoog GS, Wollenzien U. 1996 - Trimmatostroma abietis sp. nov. (hyphomycetes) and related species. Antonie van Leeuwenhoek Journal of Microbiology 69, 203-209.

Butin H, Parameswaran N. 1980 - Ultrastructure of Ascodichaena rugosa on Beech Bark. Archives of Microbiology 126, 87-95.

Butin H. 1977 - Taxonomy and morphology of Ascodichaena rugosa gen. et sp. nov. Transactions of the British Mycological Society 69, 249-254.

CABI 2017 - Gremmeniella abietina (Brunchorstia disease). In: Invasive Species Compendium. Wallingford, UK: CAB International. www.cabi.org/isc.

Cain RF. 1948 - Myriogonium, a new genus among simplified ascomycetes. Mycologia 40, 158167.

Cain RF, Kimbrough W. 1969 - Coprobolus, a new genus of the tribe Theleboleae (Pezizaceae). Canadian Journal of Botany 47, 1911-1914.

Calduch M, Gené J, Cano J, Stchigel AM, Guarro J. 2004 - Three new species of Oidiodendron Robak from Spain. Studies in Mycology 50, 159-170.

Cameldi I, Neri F, Menghini M, Pirondi A et al. 2017 - Characterization of Neofabraea vagabunda isolates causing apple bull's eye rot in Italy (Emilia-Romagna region). Plant Pathology 66, 1432-1444.

Campbell J, Marvanová L, Gulis V. 2009 - Evolutionary relationships between aquatic anamorphs and teleomorphs: Tricladium and Varicosporium. Mycological research 113, $1322-1334$.

Cannon PF, Minter DW. 1986 - The Rhytismataceae of the Indian subcontinent. Mycological Papers 155, 1-123.

Carbone I, Kohn LM. 1999 - A method for designing primer sets for speciation studies in filamentous ascomycetes. Mycologia 91, 553-556.

Carpenter SE. 1981 - Monograph of Crocicreas (Ascomycetes, Helotiales, Leotiaceae). Memoirs of the New York Botanical Garden 33, 1-290. 
Carpenter SE, Dumont KP. 1978 - Los hongos de Colombia - IV. Bisporella triseptata and its allies in Colombia. Caldasia 12, 339-348.

Chalkley D. 2018 - Systematic Mycology and Microbiology Laboratory, ARS, USDA. Invasive Fungi. Crumenulopsis pine dieback -Crumenulopsis sororia. Retrieved November 28, 2018, from /sbmlweb/fungi/index.cfm.

Chastagner GA, Riley K, Coats KP, Eikemo H, Talgø V. 2017 - Delphinella shoot blight and Grovesiella canker on Abies lasiocarpa in western USA. Scandinavian Journal of Forest Research 32, 432-437.

Cheewangkoon R, Groenewald JZ, Summerell BA, Hyde KD et al. 2009 - Myrtaceae, a cache of fungal biodiversity. Persoonia 23, 55-85.

Chen C, Verkley GJ, Sun G, Groenewald JZ, Crous PW. 2016 - Redefining common endophytes and plant pathogens in Neofabraea, Pezicula, and related genera. Fungal Biology 120, 12911322.

Chlebická M, Konvalinková T. 2010 - Pirottaea lychnidis comb. nov. from the Bohemian Switzerland National Park, Czech Republic. Czech Mycology 62, 19-32.

Chlebická M, Chlebicki A. 2007 - Cyathicula brunneospora and Pirottaea atrofusca, two new Helotiales from Tian Shan (Kazakhstan). Mycotaxon 100, 37-50.

Chlebicki A. 1990 - Brunnipila calycioides (Rehm) Baral an alpine fungus new to Poland. Acta Mycologica 26, 33-36.

Cho SE, Lee SH, Lee SK, Seo ST, Shin HD. 2018 - Erysiphe alphitoides causes powdery mildew on Eucalyptus gunnii. Forest Pathology 48, e12377.

Coetsee C, Wingfield MJ, Crous PW, Wingfield BD. 2000 - Xenochalara, a new genus of dematiaceous hyphomycetes for chalara-Iike fungi with apical wall building conidial development. South African Journal of Botany 66, 99-103.

Corner EJH. 1930 - Studies in the morphology of discomycetes. III. The Clavuleae. Transactions of the British Mycological Society 15, 107-120.

Crous PW, Wingfield MJ. 1994 - Sporendocladia fumosa and Lauriomyces bellulus sp. nov. from Castanea cupules in Switzerland. Sydowia 46, 193-203.

Crous PW, Braun U, Groenewald JZ. 2007 - Mycosphaerella is polyphyletic. Studies in Mycology $58,1-32$.

Crous PW, Summerell BA, Shivas RG, Romberg M et al. 2011 - Fungal Planet description sheets: 92-106. Persoonia 27, 130-62.

Crous PW, Summerell BA, Shivas RG, Burgess TI et al. 2012 - Fungal Planet description sheets: 107-127. Persoonia 28, 138-82.

Crous PW, Quaedvlieg W, Hansen K, Hawksworth DL, Groenewald JZ. 2014 - Phacidium and Ceuthospora (Phacidiaceae) are congeneric: taxonomic and nomenclatural implications. IMA Fungus 5, 173-193.

Crous PW, Schumacher RK, Wingfield MJ, Lombard L et al. 2015 - Fungal Systematics and Evolution: FUSE 1. - Sydowia 67, 81-118.

Crous PW, Wingfield MJ, Richardson DM, Le Roux JJ et al. 2016 - Fungal Planet description sheets: 400-468. Persoonia, 36, 316-458.

Crous PW, Wingfield MJ, Burgess TI, Carnegie AJ et al. 2017 - Fungal Planet description sheets: 625-715. Persoonia 39, 270-467.

Crous PW, Wingfield MJ, Burgess TI, Hardy G et al. 2018 - Fungal Planet description sheets: 716784. Persoonia 40, 240-393.

Czarnota P, Hernik E. 2013 - Mniaecia jungermanniae and Puttea margaritella (lichenized Ascomycota) found in Poland. Acta Societatis Botanicorum Poloniae 82, 175-179.

Damm U, Fourie PH, Crous PW. 2010 - Coniochaeta (Lecythophora), Collophora gen. nov. and Phaeomoniella species associated with wood necroses of Prunus trees. Persoonia 24, 60-80.

Darker GD. 1963 - A new genus of Phacidiaceae on Picea mariana. Canadian Journal of Botany 41, 1389-1393. 
de Hoog GS, Göttlich E, Platas G, Genilloud O et al. 2005 - Evolution, taxonomy and ecology of the genus Thelebolus in Antarctica. Studies in Mycology 51, 33-76.

de Menezes GC, Godinho VM, Porto BA, Gonçalves VN, Rosa LH. 2017 - Antarctomyces pellizariae sp. nov., a new, endemic, blue, snow resident psychrophilic ascomycete fungus from Antarctica. Extremophiles 21, 259-269.

De Notaris G. 1863 - Proposte di alcune rettificazioni al profilo dei Discomiceti. Commentario della Società Crittogamologica Italiana 1, 357-388.

Dean R, Van Kan JA, Pretorius ZA, Hammond-Kosack KE, Di Pietro A, Spanu PD, Rudd JJ, Dickman M, Kahmann R, Ellis J, Foster GD. 2012 - The Top 10 fungal pathogens in molecular plant pathology. Molecular Plant Pathology 13, 414-30.

Decock C, Rodriguez GD, Seifert K. 2005 - Taxonomy and phylogeny of Synchaetomella lunatospora, a new genus and species of synnematous fungi from Southeast Asia. Antonie van Leeuwenhoek 88, 231-240.

Delgado G, Miller AN, Fernández FA. 2015 - Curviclavula, a new genus of anamorphic Helotiales (Leotiomycetes) isolated from air. Mycological Progress 14, 3-9.

Dennis RWG. 1956 - British Ascomycetes. Mycological Papers 62, 168.

Dennis RWG. 1962 - A reassessment of Belonidium Mont. \& Dur. Persoonia 2, 171-191.

Dennis RWG. 1964 - The fungi of the Isle of Rhum. Kew Bulletin 19, 77-127.

Dennis RWG. 1968 - British Ascomycetes. J. Cramer, Lehre.

Dennis RWG. 1974 - New or interesting British microfungi. II. Kew Bulletin 29, 157-179.

Dennis RWG. 1975 - New or Interesting British Microfungi, III. Kew Bulletin 30, 345-365.

Dennis RWG, Spooner BM. 1993 - The fungi of North Hoy, Orkney - II. Persoonia 15, 169-177.

DiCosmo F, Nag Raj TR, Kendrick WB. 1984 - A revision of the Phacidiaceae and related anamorphs. Mycotaxon 21, 1-234.

DiCosmo F, Peredo H, Minter DW. 1983 - Cyclaneusma gen. nov., Naemacyclus and Lasiostictis, a nomenclatural problem resolved. European Journal of Forest Pathology 13, 206-212.

Diederich P, Ertz D, Etayo J. 2010 - An enlarged concept of Llimoniella (lichenicolous Helotiales), with a revised key to the species and notes on related genera. Lichenologist 42, 253-269.

Diederich P, Coppins B. 2014 - Diplolaeviopsis symmictae (Helotiales, Ascomycota), a new lichenicolous fungus on Lecanora symmicta. Bulletin de la Société des naturalistes Luxembourgeois 115, 151-155.

Diederich P, Etayo J. 2000 - A synopsis of the genera Skyttea, Llimoniella and Rhymbocarpus (lichenicolous Ascomycota, Leotiales). Lichenologist 32, 423-485.

Diederich P, Etayo J. 2004 - Skyttea. In: Nash III, T.H., Ryan, B.D., Diederich, P., Gries, C. \& Bungartz, F. (Eds.) Lichen Flora of the Greater Sonoran Desert Region, Vol. 2. Lichens Unlimited, Arizona State University, Tempe, Arizona, pp. 693-695.

Digby S, Goos RD. 1987 - Morphology, development and taxonomy of Loramyces. Mycologia 79, 821-831.

Dimova M, Titjnov M, Arnaudov V, Gandev S. 2014 - Harmful effect of Cherry leaf spot (Blumeriella jaapii) on Sour Cherry and influence on fruit yield. Agroznanje 15, 393-400.

Dixon JR. 1974 - Chlorosplenium and its segregates. I. Introduction and the genus Chlorosplenium. Mycotax on 1, 65-104.

Donner CD, Cuzzupe AN, Falzon CL, Gill M. 2012 - Investigations towards the synthesis of xylindein, a blue-green pigment from the fungus Chlorociboria aeruginosa. Tetrahedron 68, 2799-2805.

Dougoud R, Hairaud M, Van Vooren N. 2012 - Pirottaea trichostoma (Helotiales), une espèce remarquable et rarement découverte. Ascomycete.org 4, 119-123.

Doveri F, Sarrocco S, Vannacci G. 2013 - Studies on three rare coprophilous plectomycetes from Italy. Mycotaxon 124, 279-300.

Doveri F. 2007 - An updated key to coprophilous Pezizales and Thelebolales in Italy. Mycologia Montenegrina 10, 55-82. 
Duan JX, Wu WP, Liu XZ. 2007 - Reinstatement of Coleonaema for Coleophoma oleae and notes on Coleophoma. Fungal Diversity 26, 187-204.

Duarte S, Bärlocher F, Pascoal C, Cássio F. 2016 - Biogeography of aquatic hyphomycetes: Current knowledge and future perspectives. Fungal Ecology 19, 169-181.

Edwards RL, Kale N. 1965 - The structure of xylindein. Tetrahedron 21, 2095-2107.

Egertová Z, Gaisler J, Zemanová L, Hradílek Z. 2016a - Mniaecia jungermanniae (Helotiales), an overlooked bryophilous ascomycete in the Liberec Region (Czech Republic). Czech Mycology 68, 149-165.

Egertová Z, Hairaud M, Sochor M. 2016b - Belonioscyphella hypnorum (Helotiales), a rarely reported bryoparasitic ascomycete new for the Czech Republic. Ascomycete.org 8, 91-95.

Egger MC. 1968 - Morphologie und Biologie von Pseudophacidium -Arten (Ascomycetes). Doctoral dissertation, ETH Zürich, Zürich Switzerland.

Ekanayaka AH, Ariyawansa HA, Hyde KD, Jones EBG et al. 2017 - DISCOMYCETES: the apothecial representatives of the phylum Ascomycota. Fungal Diversity 87, 237-298.

Ekanayaka AH, Daranagama DA, Ariyawansa HA, Jones EBG et al. 2016 - Pezicula chiangraiensis sp. nov. from Thailand. Mycotaxon 131, 739-748.

Eriksson OE, Winka K. 1997 - Supraordinal taxa of Ascomycota. Myconet 1, 1-16.

Eriksson O. 1982 - Outline of the ascomycetes. Mycotaxon 15, 203-248.

Eriksson OE. 1986 - Lahmia Körber (= Parkerella A. Funk) a misinterpreted genus with isolated position. Mycotaxon 27, 347-360.

Eriksson OE. 1992 - Huangshania verrucosa gen. et sp. nov. (Triblidiaceae, Triblidiales ordo nov.), a discomycete on Pinus from China. Systema Ascomycetum 11, 1-10.

Ertz D, Diederich P. 2006 - Gelatinopsis leptogii (Helotiales, Ascomycota), a new lichenicolous fungus on Leptogium byssinum from Belgium and Germany. Lichenologist 38, 515-518.

Etayo J, Flakus A, Suija A, Kukwa M. 2015 - Macroskyttea parmotrematis gen. et sp. nov. (Helotiales, Leotiomycetes, Ascomycota), a new lichenicolous fungus from Bolivia. Phytotaxa 224, 247-257.

Fehrer J, Réblová M, Bambasová V, Vohník M. 2019 - The root-symbiotic Rhizoscyphus ericae aggregate and Hyaloscypha (Leotiomycetes) are congeneric: Phylogenetic and experimental evidence. Studies in Mycology 92, 195-225.

Fenwick GA. 1992 - A conidial form of Bulgaria inquinans. Mycologist 6, 177-179.

Fiuza PO, Gusmão LFP. 2013 - Ingoldian fungi from the semi-arid Caatinga biome of Brazil. Mycosphere 4, 1133-1150.

Fiuza PO, Gusmão LF, Castañeda-Ruiz RF. 2015 - Synchaetomella aquatica sp. nov. from submerged leaves from Brazil. Mycotaxon 130, 1135-1139.

Fiuza PO, Pérez TC, Gulis V, Gusmao LF. 2017 - Ingoldian fungi of Brazil: some new records and a review including a checklist and a key. Phytotaxa 306, 171-200.

Fuhrer BA, May TW. 1993 - Host specificity of disc-fungi in the genus Banksiamyces on Banksia. Victorian Naturalist 110, 73-75.

Funk A. 1977 - A new Grovesiella on grand fir. Canadian Journal of Botany 56, 245-247.

Funk A. 1979 - New species of Gelatinosporium on western conifers. Canadian Journal of Botany $57,765-767$.

Galán R, Checa J, Blanco MN, Platas G et al. 2015 - Taxonomic position of the genus Bicornispora and the appearance of a new species Bicornispora seditiosa. Mycologia 107, 793-807.

Gamundí IJ. 1971 - Las Cyttariales Sudamericanas (Fungi, Ascomycetes). Darwiniana 16, 461510.

Gamundi IJ. 1977 - Subantarctic Geoglossaceae. II. Kew Bulletin 31, 731-739.

Ge ZW, Yang ZL, Pfister DH, Carbone M et al. 2014 - Multigene Molecular Phylogeny and Biogeographic Diversification of the Earth Tongue Fungi in the Genera Cudonia and Spathularia (Rhytismatales, Ascomycota). PLoS ONE 9, e103457. 
Geesteranus RA. 1972 - Spathularia and Spathulariopsis. Proceedings of the Koninklijke Nederlandse Akademie van Wetenschappen. Series C. Biological and Medical Sciences 45, 243-255.

Gernandt DS, Platt JL, Spatafora JW, Holst-Jensen A et al. 2001 - Phylogenetics of Helotiales and Rhytismatales based on partial small subunit nuclear ribosomal DNA sequences. Mycologia 93, 915-933.

Giordano L, Gonthier P. 2011 - An outbreak of Cyclaneusma minus needle cast on Swiss mountain pine (Pinus uncinata) in Italy. Journal of Plant Pathology 93, 54-74.

Glawe DA. 2006 - Synopsis of genera of Erysiphales (powdery mildew fungi) occurring in the Pacific Northwest. Pacific Northwest Fungi 1, 1-27.

Gminder A. 2006 - Studies in the genus Mollisia s. 1. II: Revision of some species of Mollisia and Tapesia described by J. Velenovský (part 1). Czech Mycology 58, 125-148.

Gminder A. 2012 - Studies in the genus Mollisia s.l. III: Revision of some species of Mollisia and Tapesia described by J. Velenovský (part 2). Czech Mycology 64, 105-126.

Goh TK, Hyde KD. 1998 - A synopsis of and a key to Diplococcium species, based on the literature, with a description of a new species. Fungal Diversity 1, 65-83.

Goh TK, Hyde KD, Umali TE. 1998 - Two new species of Diplococcium from the tropics. Mycologia 90, 514-517.

Goncalves VN, Vaz ABM, Rosa CA, Rosa LH. 2012 - Diversity and distribution of fungal communities in lakes of Antarctica. FEMS Microbiology Ecology 82, 459-471.

Gönczöl J, Révay Á. 2003 - Treehole fungal communities: aquatic, aero-aquatic and dematiaceous hyphomycetes. Fungal Diversity 12, 19-34.

Goodwin SB. 2002 - The barley scald pathogen Rhynchosporium secalis is closely related to the discomycetes Tapesia and Pyrenopeziza. The British Mycological Society 106, 645-654.

Graddon WD. 1990 - Some new Discomycete species 8. Mycological Research 94, 231-236.

Graddon WD. 1984 - Some new discomycete species: 6. Transactions of the British Mycological Society $83,377-382$.

Gramaje D, Mostert L, Armengol J. 2011 - Characterization of Cadophora luteo-olivacea and C. melinii isolates obtained from grapevines and environmental samples from grapevine nurseries in Spain. Phytopathologia Mediterranea 50, S112-S126.

Gremmen J. 1958 - Taxonomical notes on mollisiaceous fungi - VI. The genus Pyrenopeziza Fuck. Fungus 28, 37-46.

Grove WB. 1937 - British stem-and leaf-fungi (Coelomycetes). A contribution to oar knowledge of the fungi Imperfecti belonging to the Sphaeropsidales and the Melanconiales. Volume II. Cambridge University Press.

Groves WJ. 1952 - The genus Tympanis. Canadian Journal of Botany 30, 571-651.

Groves JW. 1954 - The genus Durandiella. Canadian Journal of Botany 32, 116-144.

Groves JW. 1965 - The genus Godronia. Canadian Journal of Botany 43, 1195-1278.

Groves JW. 1967 - The genus Pragmopora. Canadian Journal of Botany 45, 169-181.

Groves JW. 1968 - Two new species of Ascocalyx. Canadian Journal of Botany 46, 1273-1278.

Grünig CR, Sieber TN, Rogers SO, Holdenrieder O. 2002 - Genetic variability among strains of Phialocephala fortinii and phylogenetic analysis of the genus Phialocephala based on rDNA ITS sequence comparisons. Canadian Journal of Botany 80, 1239-1249.

Guatimosim E, Schwartsburd PB, Crous PW, Barreto RW. 2016 - Novel fungi from an ancient niche: lachnoid and chalara-like fungi on ferns. Mycological Progress 15, 1239-1267.

Haeckel E. 1894 - Systematische Phylogenie der Protisten und Pflanzen. Entwurf eines natürlichen Systems der Organismen auf Grund ihrer Stammesgeschichte. [T. 1] Systematische Phylogenie der Protisten und Pflanzen. 1, 1-400.

Haelewaters D, Filippova NV, Baral H-O. 2018 - A new species of Stamnaria (Leotiomycetes, Helotiales) from Western Siberia. MycoKeys 32, 49-63.

Haines JH, Dumont KP. 1983 - Studies in the Hyaloscyphaceae II: Proliferodiscus, a New Genus of Arachnopezizoideae. Mycologia 75, 535-543. 
Hall T. $2004-$ BioEdit. Ibis Therapeutics, Carlsbad. http://www.mbio. ncsu.edu/BioEdit/bioedit.html.

Han JG, Hosoya T, Shin HD. 2011 - Amicodisca castaneae sp. nov. (Hyaloscyphaceae, Helotiales) on Japanese chestnut bur. Mycotaxon 118, 89-94.

Han JG, Hosoya T, Sung GH, Shin HD. 2014 - Phylogenetic reassessment of Hyaloscyphaceae sensu lato (Helotiales, Leotiomycetes) based on multigene analyses. Fungal Biology 118, $150-167$.

Hawksworth DL, Sutton BC, Ainsworth GC. 1983 - Ainsworth \& Bisby's dictionary of the fungi, 7th edn. Commonwealth Mycological Institute, Kew.

Hawksworth DL, Eriksson OE. 1986 - The names of accepted orders of Ascomycetes. Systema Ascomycetum 5, 175-184.

Hein B. 1983 - Die Gattung Hysterostegiella v. Höhnel (Ascomycetes, Dermateaceae). Nova Hedwigia 38, 669-702

Hein B. 1976 - Revision der Gattung Laetinaevia Nannf. (Ascomycetes) und Neuordnung der Naevioideae. Willdenowia Beiheft 9, 1-136.

Hernández-Restrepo M, Silvera-Simón C, Mena-Portales J, Mercado-Sierra Á et al. 2012 - Three new species and a new record of Diplococcium from plant debris in Spain. Mycological Progress 11, 191-199.

Hernandez-Restrepo M, Gené J, Castañeda-Ruiz RF, Mena-Portales J et al. 2017 - Phylogeny of saprobic microfungi from Southern Europe. Studies in Mycology 86, 53-97.

Herrera P, Suarez JP, Kottke I. 2010 - Orchids keep the ascomycetes outside: a highly diverse group of ascomycetes colonizing the velamen of epiphytic orchids from a tropical mountain rainforest in Southern Ecuador. Mycology 1, 262-268.

Higgins KL, Coley PD, Kursar TA, Arnold AE. 2011 - Culturing and direct PCR suggest prevalent host generalism among diverse fungal endophytes of tropical forest grasses. Mycologia 103, 247-260.

Höhnel von F. 1917 - System der Phacidiales. Berichte der Deutschen Botanischen Gesellschaft $35,416-422$.

Holst-Jensen A, Kohn LM, Schumacher T. 1997 - Nuclear rDNA phylogeny of the Sclerotiniaceae. Mycologia 89, 885-899.

Hongsanan S, Hyde KD, Bahkali AH, Camporesi E et al. 2015 - Fungal Biodiversity Profiles 1120. Cryptogamie Mycologie 36, 355-380.

Hoog GS de, Göttlig E, Platas G, Genilloud O et al. 2005 - Evolution, taxonomy and ecology of the genus Thelebolus in Antarctica. Studies in Mycology 51, 33-76.

Hosoya T, Otani Y. 1995 - Gelatinipulvinella astraeicola gen. et sp. nov., a fungicolous discomycetes and its anamorph. Mycologia 87, 689-696.

Hosoya T, Otani Y. 1997 - Lambertella advenula, a new combination proposed for Moellerodiscus advenulus, new to Japan. Mycoscience 38, 297-303

Hosoya T, Zhao YJ. 2016 - Enumeration of remarkable Japanese discomycetes (10): two Helotiales and a Helotialean Anamorph new to Japan. Bulletin of the National Museum of Nature and Science. Series B, Botany 42, 113-119.

Hosoya T, Sasagawa R, Hosaka K, Sung GH et al. 2010 - Molecular phylogenetic studies of Lachnum and its allies based on the Japanese material. Mycoscience 51, 170-181.

Hosoya T, Zhao Y, Degawa Y. 2014 - Poculum pseudosydowianum, sp. nov. (Rutstroemiaceae, Ascomycota) from Japan and its endophytic occurrence. Phytotaxa 175, 216-224.

Hou CL, Piepenbring M. 2009 - Two New Rhytismatales on Rhododendron from China. Mycologia 101, 383-389.

Hou CL, Piepenbring M. 2006 - Five new species of Hypoderma with a key to Hypoderma species for China. Nova Hedwigia 82, 91-104.

Hou CL, Trampe T, Piepenbring M. 2010 - A New Species of Rhytisma Causes Tar Spot on Comarostaphylis arbutoides (Ericaceae) in Panama. Mycopathologia 169, 225-229. 
Hughes SJ. 1953 - Conidiophores, conidia, and classification. Canadian Journal of Botany 31, 577659.

Huhtinen S. 1985 - Finnish records of discomycetes: Unguicularia equiseti sp.nov. and Albotricha laetior. Karstenia 25, 17-20.

Huhtinen S. 1987a - Three new species, and the histochemical delimitation of genera in the glassyhaired Hyaloscyphaceae. Mycotaxon 29, 267-283.

Huhtinen S. 1987b - Taxonomic studies in the genera Protounguicularia, Arachnopeziza and Dematioscypha. Mycotaxon 30, 9-28.

Huhtinen S. 2001 - Redisposition of some taxa of Pseudolachnea, with some other transfers. Österreichische Zeitschrift für Pilzkunde 10, 1-13.

Huhtinen S, Spooner B. 2005 - Unguiculella tityrii: a fimicolous and fungicolous novelty to the mycoflora of Britain. Mycologist 19, 59-61.

Huhtinen S, Santesson R. 1997 - A New Lichenicolous Species of Polydesmia (Leotiales: Hyaloscyphaceae). Lichenologist 29, 205-208.

Hujslová M, Kubátová A, Kostovčík M, Blanchette RA, De Beer ZW et al. 2014 - Three new genera of fungi from extremely acidic soils. Mycological Progress 13, 819-831.

Hunter S, Glen M, McDougal R. 2016 - Molecular tools for differentiating Cyclaneusma minus morphotypes and assessing their distribution in Pinus radiata forests in New Zealand. New Zealand Journal of Forestry Science 46, 21-31.

Hustad VP, Miller AN. 2011 - Phylogenetic placement of four genera within the Leotiomycetes (Ascomycota). North American Fungi 6, 1-13.

Hütter R. 1958 - Untersuchungen tiber die Gattung Pyrenopeziza Fuck. Phytopathologische Zeitschrift 33, 1-54.

Huelsenbeck JP, Ronquist F. 2000 - MrBayes: Bayesian inferences of phylogeny (software). University of Rochester, New York.

Hyde KD, Maharachchikumbura SSN, Hongsanan S, Samarakoon MC et al. 2017 - The ranking of fungi-a tribute to David L. Hawksworth on his $70^{\text {th }}$ birthday. Fungal Diversity 84, 1-23.

Ihlen, PG, Wedin, M 2006 - Notes on two lichenicolous fungi on Cladonia botrytes in Scandinavia. Graphis Scripta 18, 38-40.

Index Fungorum 2019 - http://www.indexfungorum.org/Names/Names.asp. Accessed Jan 2019.

Ingold CT. 1942 - Aquatic hyphomycetes of decaying alder leaves. Transactions of the British Mycological Society 25, 339-417.

Ingold CT, Chapman B. 1952 - Aquatic Ascomycetes: Loramyces juncicola Weston and L. macrospora $\mathrm{n}$. sp. Transactions of the British Mycological Society 35, 268-272.

Inman AJ, Fitt BDL, Evans RL. 1992 - A species of Unguicularia on oilseed rape, and its importance in studies of the epidemiology of light leaf spot (Pyrenopeziza brassicae). Plant Pathology 41, 646-652.

Iturriaga T, LoBuglio KF, Pfister DH. 2017 - Bulgariella pulla, a Leotiomycete of uncertain placement, with an uncommon type of ascus opening. Mycologia 109, 900-911.

Iturriaga T, Korf RP. 1990 - A monograph of the discomycete genus Strossmayeria (Leotiaceae), with comments on its anamorph, Pseudospiropes (Dematiaceae). Mycotaxon 36, 383-454.

Iturriaga T, Israel HW. 1985 - Studies in the genus Strossmayeria (Helotiales). 5. Conidia and conidiogenesis in Pseudospiropes: a light and electron microscope investigation. Canadian Journal of Botany 63, 195-200.

Jaklitsch W, Baral HO, Lucking R, Lumbsch HT. 2016 - Ascomycota. In: Frey W (ed) Syllabus of plant families-Adolf Engler's Syllabus der Pflanzenfamilien. Borntraeger, Stuttgart.

Jansson HB, von Hofsten A, von Mecklenburg C. 1984 - Life cycle of the endoparasitic nematophagous fungus Meria coniospora: a light and electron microscopic study. Antonie Van Leeuwenhoek 50, 321-327.

Jayasiri SC, Hyde KD, Ariyawansa HA, Bhat J et al. 2015 - The Faces of Fungi database: fungal names linked with morphology, phylogeny and human impacts. Fungal Diversity 74, 3-18. 
Jeger M, Caffier D, Candresse T, Chatzivassiliou E et al. 2017 - Scientific Opinion on the pest risk assessment of Atropellis spp. for the EU territory. EFSA Journal 15, 4877-4923.

Jeewon R, Hyde KD. 2016 - Establishing species boundaries and new taxa among fungi: recommendations to resolve taxonomic ambiguities. Mycosphere 7, 1669-1677.

Johnston PR. 2002 - Three new species of Moellerodiscus (Helotiales, Rutstroemiaceae) from New Zealand. New Zealand Journal of Botany 40, 105-115.

Johnston PR, Park D, Baral HO, Galán R et al. 2014 - The phylogenetic relationships of Torrendiella and Hymenotorrendiella gen. nov. within the Leotiomycetes. Phytotaxa 177, 001-025.

Johnston PR, Park D. 2005 - Chlorociboria (Fungi, Helotiales) in New Zealand. New Zealand Journal of Botany 43, 679-719.

Johnston PR, Park D. 2010 - Neobulgaria alba sp. nov. and its Phialophora-like anamorph in native forests and kiwi fruit orchards in New Zealand. Mycotaxon 113, 385-396.

Johnston PR. 2006 - Rhytismatales of Australia: the genus Marthamyces. Australian Systematic Botany 19, 135-146.

Johnston PR. 1989 - Lophodermium (Rhytismataceae) on Clusia. Sydowia 41, 170-179.

Johnston PR. 1988 - A new species of Meloderma (Rhytismataceae), with notes on Meloderma and related genera. Mycotaxon 33, 423-436.

Johnston PR. 2001a - Rhytismatales of Australasia. Australian Systematic Botany 14, 377-384.

Johnston PR. 2001b - Monograph of the monocotyledon-inhabiting species of Lophodermium. Mycological Papers 176, 1-239.

Jones SG. 1925 - Life-history and Cytology of Rhytisma acerinum (Pers.) Fries. Annals of Botany 39, 41-75.

Jones L, Riaz S, Morales-Cruz A, Amrine KC et al. 2014 - Adaptive genomic structural variation in the grape powdery mildew pathogen, Erysiphe necator. BMC Genomics 15, 1081-1099.

Jooste WJ, van der Merwe WJJ. 1990 - Ultrastructure of the conidiogenesis and conidia of Anguillospora pseudolongissima and Flagellospora penicillioides. South African Journal of Botany 56, 319-325.

Joshi Y, Kondratyuk S, Lökös L, Halda JP et al. 2015 - New species and new records of lichenicolous fungi from South Korea. Mycosphere 6, 493-500.

Joshi Y, Falswal A, Joshi R. 2017 - A new species of lichenicolous fungus Epicladonia from India. Kavaka 48, 42-43.

Jülich W, de Vries B. 1982 - On the genera Ascocorticium and Ascosorus (Ascocorticiaceae). Persoonia 11, 407-420.

Khan KA, Nabi SU, Khan NA. 2017 - Identification of Cylindrosporium padi associated with leaf spot disease of cherry in Kashmir Valley, India. Journal of Phytopathology and Pest Management 3, 43-52.

King KM, West JS, Brunner PC, Dyer PS, Fitt BDL. 2013 - Evolutionary relationships between Rhynchosporium lolii sp. nov. and other Rhynchosporium species on grasses. PLoS ONE 8, e72536.

Kirschner R, Oberwinkler F. 2001 - Mycoparasitism by three species of Diplococcium (Hyphomycetes). Plant Biology 3, 449-454.

Kocourková J, Knudsen K. 2009 - Gelatinopsis acarosporicola (Helotiaceae), a new lichenicolous fungus on Acarospora socialis from western North America. The Bryologist 112, 363-367.

Kohn LM. 1989 - Chlorovibrissea (Helotiales, Leotiaceae), a New Genus of Austral Discomycetes. Memoirs of the New York Botanical Garden 49, 112-118.

Kohn LM, Nagasawa E. 1984 - The genus Scleromitrula (Sclerotiniaceae), Episclerotium gen. nov. (Leotiaceae) and allied stipitate-capitate species with reduced ectal excipula. Transactions of the Mycological Society of Japan 25, 127-148.

Konig H, Unden G, Frohlich J. 2009 - Biology of Microoganisms on Grapes, in Must and in Wine: 4.3.3 Pseudopezicula tracheiphila. Springer, Cham. 
Korf RP. 1962 - A synopsis of the Hemiphacidiaceae, a family of the Helotiales (discomycetes) causing needle-blights of conifers. Mycologia 54:12-33

Korf RP, Lizon P. 2001 - The status of the ordinal name Leotiales. Czech Mycology 52, 255-257.

Korf RP. 1951 - Arachnopeziza obtusipila Grelet descr. emend. Mycologia 43, 211-214.

Korf RP. 1952 - A monograph of the Arachnopezizeae. Lloydia 14, 129-180.

Korf RP. 1973 - Discomycetes and Tuberales. In: Ainsworth GC, Sparrow FK, Sussman AS (eds) The fungi: an advanced treatise, vol IVA. Academic Press, New York.

Korf RP, Pearson RC, Zhuang W, Dubos B. 1986 - Pseudopezicula (Helotiales, Peziculoideae), A new discomycete genus for pathogens causing an angular leaf scorch disease of grapes ("rotbrenner"). Mycotaxon 26, 457-471.

Korf RP, Abawi GS. 1971 - On Holwaya, Crinula, Claussenomyces and Corynella. Canadian Journal of Botany 49, 1879-1883.

Katoh K, Rozewicki J, Yamada KD. 2017 - MAFFT online service: multiple sequence alignment, interactive sequence choice and visualization. Briefings in Bioinformatics bbx, 108.

Koukol O. 2011 - New species of Chalara occupying coniferous needles. Fungal Diversity 49, 7592.

Koukol O. 2012 - A new species of Infundichalara from pine litter. Mycotaxon120, 343-352.

Kowalski T, Bartnik C. 2010 - Morphologial variation in colonies of Chalara fraxinea isolated from ash (Fraxinus excelsior L.) stems with symptoms of dieback and effects of temperature on colony growth and structure. Acta Agrobotanica 63, 99-106.

Kučera V, Lizoň P, Tomšovský M. 2017 - Taxonomic divergence of the green naked-stipe members of the genus Microglossum (Helotiales). Mycologia 109, 46-54.

Kucera V, Tomšovský M, Lizon` P. 2014 - A new green earth-tongue Microglossum parvisporum sp. nov. Sydowia 66, 335-343.

Kunca A, Leontovyč R. 2013 - Laboratórne pokusy s potencionálnym rastom Cenangium ferruginosum na prírodných živných pôdach. Lesnícky časopis. Forestry Journal 59, 44-49.

Kuo M. 2013 - Ascocoryne cylichnium. Retrieved from the MushroomExpert.Com Web site: http://www.mushroomexpert.com/ascocoryne_cylichnium.html.

Kušan I, Matočec NE, Antonić OL, Hairaud M. 2014 - Biogeographical variability and redescription of an imperfectly known species Hamatocanthoscypha rotundispora (Helotiales, Hyaloscyphaceae). Phytotaxa 170, 001-012.

Lantz H, Johnston PR, Park D, Minter DW. 2011 - Molecular phylogeny reveals a core clade of Rhytismatales. Mycologia 103, 57-74.

Lee DH, Back CG, Win NK, Choi KH et al. 2011 - Biological characterization of Marssonina coronaria associated with Apple Blotch disease. Mycobiology 39, 200-205.

Legon N. 2012 - Cheirospora botryospora - a very common rarity? Field Mycology 13, 128-130.

Leuchtmann A. 1987 - Species of Heterosphaeria (Discomycetes) and their anamorphs. Mycotaxon 28, 261-284.

Li ZJ, Taylor JE, Hou CL. 2016 - An unusual Lophodermium species on needles of Pinus taiwanensis from China. Mycological Progress 15, 1229-1237.

Lin H, Jiang X, Yi J, Wang X et al. 2018 - Molecular identification of Neofabraea species associated with bull's eye rot on apple using rolling-circle amplification of partial EF-1 $\alpha$ sequence. Canadian Journal of Microbiology 64, 57-68.

Liu XX, Zhuang WY, Zeng ZQ, Zhao P. 2016 - Newly discovered sclerotiniaceous fungi from China. Nova Hedwigia 102, 347-357.

Liu YJ, Whelen S, Hall BD. 1999 - Phylogenetic relationships among Ascomycetes: evidence from an RNA polymerase II subunit. Molecular Biology and Evolution 16, 1799-1808.

Livsey S, Minter DW. 1994 - The taxonomy and biology of Tryblidiopsis pinastri. Canadian Journal of Botany 72, 549-557.

Liyanage KK, Khan S, Brooks S, Mortimer PE et al. 2017 - Taxonomic revision and phylogenetic analyses of rubber powdery mildew fungi. Microbial Pathogenesis 105, 185-195. 
Lizon P, Iturriaga T, Korf RP. 1998 - A preliminary discomycete flora of Macaronesia: Part 18, Leotiales. Mycotaxon 67, 73-83.

LoBuglio KF, Pfister DH. 2010 - Placement of Medeolaria farlowii in the Leotiomycetes, and comments on sampling within the class. Mycological Progress 9, 36-368.

Magnes M. 1997 - Weltmonographie der Triblidiaceae. Bibliotheca Mycologica 165, 1-177.

Malloch D, Cain RF. 1971 - Four new genera of cleistothecial Ascomycetes with hyaline ascospores. Canadian Journal of Botany 49, 847-854.

Malloch D, Sigler L, Hambleton S, Vanderwolf KJ et al. 2016 - Fungi associated with hibernating bats in New Brunswick caves: the genus Leuconeurospora. Botany 94, 1171-81.

Marvanova L. 1975 - Concerning Gyoerffyella Kol. Transactions of the British Mycological Society $65,555-565$.

Marvanová L, Bärlocher F. 2001 - Hyphomycetes from Canadian streams. VI. Rare species in pure cultures. Czech Mycology 53, 1-28.

Marvanová L, Fisher PJ, Descals E, Bärlocher F. 1997 - Fontanospora fusiramosa sp. nov., a hyphomycete from live tree roots and from stream foam. Czech Mycology 50, 3-11.

Matheis Von W. 1977 - Dennisiodiscus hippocastani (Richon) combo nov., der Violette Roßkastanien-W ollbecherling. Zeitschrift für Pilzkunde 43, 213-216.

Matocec N, Scheuer C, Krisai-Greilhuber IR. 2005 - Austrian discomycetous fungi 1. An annotated list of species recently collected in the Eastern Alps and the Peripannonic area. Osterreichische Zeitschrift fur Pilzkunde 14, 309-331.

McLaughlin D, Spatafora JW. 2015 - Systematics and evolution, part 2. Volume 7, part 1 of The Mycota.

Medardi G. 2007 - Overview of the genus Claussenomyces and a description of Italian collections. Czech Mycology 59, 101-109.

Mengoni TP. 1986 - El aparato apical del asco de Cyttaria harioti (Ascomycetes-Cyttariales) con microscopıa fotonica y electronica. Boletín de la Sociedad Argentina de Botánica 24, 393401.

Meyer SLF, Luttrell LS. 1986 - Ascoma morphology of Pseudopeziza trifolii forma specialis medicaginis-sativae (Dermateaceae) on alfalfa. Mycologia 78, 529-542.

Meyer SLF, Luttrell LS. 1987 - Host-parasitic relationship between Pseudopeziza trifolii f. sp. medicaginis-sativae. Phytopathology 77, 309-319.

Michalecka M, Bryk H, Poniatowska A, Puławska J. 2016 - Identification of Neofabraea species causing bull's eye rot of apple in Poland and their direct detection in apple fruit using multiplex PCR. Plant Pathology 65, 643-654.

Miller MA, Pfeiffer W, Schwartz T. 2010 - Creating the CIPRES Science Gateway for inference of large phylogenetic trees. In Proceedings of the Gateway Computing Environments Workshop (GCE). New Orleans, LA pp 1-8.

Minter DW, Hetiige G. 1983 - Lophodermium agathidis and Meloderma richeae, two members of the Rhytismataceae from Australasia. New Zealand Journal of Botany 21, 39-48.

Minter DW. 2018 - Rhytisma acerinum. http://www.cybertruffle.org.uk/pics/0000103_htm

Minter DW. 1981 - Lophodermium on pines. Mycological Papers147, 1-54.

Möller A. 1901 - Phycomyceten und Ascomyceten. Untersuchungen aus Brasilien. Botanische Mittheilungen aus den Tropen 9, 1-319.

Montagne JPFC. 1856 - Septième centurie de plantes cellulaires nouvelles, tant indigènes qu'exotiques. Annales des Sciences Naturelles Botanique 5, 333-374.

Müller E, Dorworth CE. 1983 - On the discomycetous genera Ascocalyx Naumov and Gremmeniella Morelet. Sydowia 36, 193-203.

Müller E, Petrini O, Samuels GJ. 1979 - Obtectodiscus aquaticus gen. nov. et spec. nov., ein neuer, wasserbewohnender Ascomycet aus den Alpen. Sydowia 32, 190-197.

Müller E, Hütter R. 1963 - Eine neue Discomycetengattung aus den Alpen, Neotapesia nov. gen. Bulletin de la Société Botanique Suisse 73, 325-331. 
Munkvold GP, Neely D. 1989 - A Cylindrosporium leaf spot on oak. Journal of Arboriculture 15, $162-164$.

Nannfeldt JA. 1983 - Nimbomollisia and Discocurtisia: Two New Genera of Mollisioid Discomycetes. Mycologia 75, 292-310.

Nannfeldt JA. 1932 - Studien uber die Morphologic und Systematik der nichtlichenisierten nonoperculaten Discomyceten. Nova acta Regiae Societatis Scientiarum Upsaliensis 48, 1-368.

Nannfeldt JA. 1984 - Notes on Diplonaevia (Discomycetes inoperculati), with special regard to the species on Juncaceae. Nordic Journal of Botany 4, 791-815.

Nannfeldt JA. 1936 - Notes on type specimens of British inoperculate discomycetes (Second part, notes 51-100).Transactions of the British Mycological Society 20, 191-206.

Napoli C, Mello A, Borra A, Vizzini A et al. 2010 - Tuber melanosporum, when dominant, affects fungal dynamics in truffle grounds. New Phytologist 185, 237-247.

Nauta MM, Spooner B. 1999a - British Dermateaceae: 1. Introduction. Mycologist 13, 3-6.

Nauta MM, Spooner B. 1999b - British Dermateaceae 2. Naevioideae. Mycologist 13, 65-69.

Nauta MM, Spooner B. 1999c - British Dermateaceae : 3. Peziculoideae. Mycologist 13, 98-101.

Nauta MM, Spooner B. 1999d - British Dermateaceae: 4A . Dermateoideae - Mycologist 13: 146148.

Nauta MM, Spooner B. 2000a - British Dermateaceae 4B. Dermateoideae genera B-E. Mycologist 14, 21-28.

Nauta MM, Spooner B. 2000b - British Dermateaceae 4B. Dermateoideae genera G-Z. Mycologist 14, 65-74.

Navaud O, Barbacci A, Taylor A, Clarkson JP, Raffaele S. 2018 - Shifts in diversification rates and host jump frequencies shaped the diversity of host range among Sclerotiniaceae fungal plant pathogens. Molecular Ecology 27, 1309-1323.

Nylander JAA. 2004 - MrModeltest 2.0. Program distributed by the author. Evolutionary Biology Centre, Uppsala University, Uppsala.

Oberwinkler F, Casagrande F, Müller E. 1967 - Über Ascocorticium anomalum (Ell. \& Harkn.) Earle. Nova Hedwigia 14, 283-289.

Ohenoja E, Wang Z, Townsend JP, Mitchel D, Voitk A. 2010 - Northern species of earth tongue genus Thuemenidium revisited, considering morphology, ecology and molecular phylogeny. Mycologia 102, 1089-1095.

Oliveira RV, Lima TEF, Cunha IB, Coimbra VRM et al. 2014 - Corniculariella brasiliensis, a new species of coelomycetes in the rhizosphere of Caesalpinia echinata (Fabaceae, Caesalpinioideae) in Brazil. Phytotaxa 178, 197-204.

Pärtel K, Baral HO, Tamm H, Põldmaa K. 2017 - Evidence for the polyphyly of Encoelia and Encoelioideae with reconsideration of respective families in Leotiomycetes. Fungal Diversity 82, 183-219.

Pärtel K. 2016 - Application of ultrastructural and molecular data in the taxonomy of helotialean fungi. Dissertationes Biologicae Universitatis Tartuensis.

Pärtel K, Põldmaa K. 2011 - A new species of Hyphodiscus (Helotiales) on Stereum. Mycotaxon $115,11-17$.

Pascoal C, Marvanová L, Cássio F. 2005 - Aquatic hyphomycete diversity in streams of Northwest Portugal. Fungal Diversity 19, 109-128.

Pearson RC, Smith FD, Dubos B. 1988 - Angular leaf scorch, a new disease of grapevines in North America caused by Pseudopezicula tetraspora. Plant Disease 72, 796-800.

Peláezf F, Colladoh J, Platasa G, Overyi DP et al. 2011 - Phylogeny and intercontinental distribution of the pneumocandin-producing anamorphic fungus Glarea lozoyensis. Mycology $2,1-17$.

Perez-Ortega S, Etayo J, Spribille T. 2011 - A new species of Llimoniella (Ascomycota, Helotiales) on Ramboldia cinnabarina from Alaska. Lichenologist 43, 363-366.

Perić B, Baral HO. 2014 - Erioscyphella curvispora Spec. Nov. from Montenegro. Mycologia Montenegrina 17, 89-104. 
Perić B, Baral HO, Pärtel K. 2015 - Cenangiopsis raghavanii and C. junipericola spp. nov. (Cenangiaceae, Helotiales) collected in Montenegro, with redescription of a recent collection of C. quercicola. Mycologia Montenegrina 18, 7-40.

Pešicová K, Kolařík M, Hortová B, Novotný D. 2017 - Diversity and identification of Neofabraea species causing bull's eye rot in the Czech Republic. European Journal of Plant Pathology 147, 683-693.

Peterson KR, Pfister DH. 2010 - Phylogeny of Cyttaria inferred from nuclear and mitochondrial sequence and morphological data. Mycologia 102, 1398-1416.

Peterson KR, Pfister DH, Bell CD. 2010 - Cophylogeny and biogeography of the fungal parasite Cyttaria and its host Nothofagus, the southern beech. Mycologia 102, 1417-1425.

Petrak F. 1951 - Cashiella n.gen., eine neue Gattung der Diskomyzeten. Sydowia 5, 371-374.

Pfister DH 1976 - Calloriopsis and Micropyxis: Two Discomycete genera in the Calloriopsideae trib. nov. Mycotaxon 4, 340-346.

Pfister DH, Kimbrough JW. 2001 - Discomycetes. In: McLaughlin DJ, McLaughlin EG, Lemke PA (eds) The mycota VII part A. Systematics and evolution. Springer, Berlin.

Pfister DH, LoBuglio KF. 2013 - Systemic infection of Medeola virginiana (Liliaceae) by the fungus Medeolaria farlowii (Ascomycota: Leotiomycetes). Mycosystema.32, 342-6.

Phillips WA. 1887 - Manual of the British Discomycetes. pp. 1-462.

Pino-Bodas R, Pérez-Vargas I, Stenroos S, Ahti T, Burgaz AR. 2015 - Sharpening the species boundaries in the Cladonia mediterranea complex (Cladoniaceae, Ascomycota). Persoonia $37,1-12$.

Pino-Bodas R, Zhurbenko MP, Stenroos S. 2017 - Phylogenetic placement within Lecanoromycetes of lichenicolous fungi associated with Cladonia and some other genera. Persoonia 39, 91-117.

Plishka MJ, Tsuneda A, Currah RS. 2008 - Evidence of apothecial ancestry in the cleistothecial ascomata of Pleuroascus nicholsonii. Mycological Research 112, 1319-1326.

Prasher IB, Sharma MP, Sharma R. 2003 - Diversity in the genus Niptera Fr. with particular reference to the Himalayan taxa. Phytomorphology 53, 249-256.

Prieto M, Schultz M, Olariaga I, Wedin M. 2018 - Lichinodium is a new lichenized lineage in the Leotiomycetes. Fungal Diversity 94, 23-39.

Quijada L, Huhtinen S, Beltran-Tejera E. 2015 - Studies in Hyaloscyphaceae associated with major vegetation types in the Canary Islands I: Cistella and Hyphodiscus. Willdenowia 45, 131-47.

Quijada L, Ribes M, Negrín R, Beltrán-Tejera E. 2017 - Lignicolous species of Helotiales associated with major vegetation types in the Canary Islands. Willdenowia 47, 271-291.

Quijada L, Johnston PR, Cooper JA, Pfister DH. 2018 - Overview of Phacidiales, including Aotearoamyces gen. nov. on Nothofagus. IMA Fungus 9, 371-382.

Raitviir A. 2004 - Revised synopsis of the Hyaloscyphaceae. Scripta Mycologica 20, 1 - 133.

Raitviir A. Spooner BM. 1994 - Cyttarlales, Lahmiales, Leotiales, Medeolariales, Ostropales, Patellarlales, Rhytismatales, and Triblidiales. In Ascomycete Systematics. D.L. Hawksworth (ed.) Springer Science Business Media New York.

Raja HA, Miller AN, Shearer CA. 2008 - Freshwater ascomycetes: Aquapoterium pinicola, a new genus and species of Helotiales (Leotiomycetes) from Florida. Mycologia 100, 141-148.

Rambaut A. 2006 - FigTree. Tree figure drawing tool version 1.3.1. Institute of Evolutionary Biology, University of Edinburgh, Edinburgh. http://tree.bio.ed.ac.uk/ software/figtree/.

Rambaut A, Drummond AJ. 2009 - Tracer. MCMC Trace analysis tool version v1.5.0. http://tree.bio.ed.ac.uk/software/tracer/.

Rannala B, Yang Z. 1996 - Probability distribution of molecular evolutionary trees: a new method of phylogenetic inference. Journal of Molecular Evolution 43, 304-311.

Ranzoni FV. 1956 - The Perfect Stage of Flagellospora penicillioides. American Journal of Botany 43, 13-17. 
Rawlinsona CJ, Suttona BC, Muthyalua G. 1978 - Taxonomy and biology of Pyrenopeziza brassicae sp.nov. (Cylindrosporium concentricum), a pathogen of winter oilseed rape (Brassica napus ssp. oleifera). Transactions of the British Mycological Society 71, 425-439.

Raymundo T, Valenzuela R, Esqueda M. (2016) Marthamyces coronadoae sp. nov. in a Fagus grandifolia subsp. mexicana forest from Hidalgo State, México. Mycotaxon 131, 521-526.

Réblová M, Gams W, Štěpánek V. 2011 - The new hyphomycete genera Brachyalara and Infundichalara, the similar Exochalara and species of 'Phialophora sect. Catenulatae' (Leotiomycetes). Fungal Diversity 46, 67-86.

Redhead SA. 1977 - The genus Mitrula in North America. Canadian Journal of Botany 55, 307325.

Rehm H. 1897 - Botaniska Notiser 1897, 259.

Rehm H. 1888 - Ascomyceten fasc. XIX. Hedwigia 27, 163-175.

Reid DA. 1986 - Amylocarpus encephaloides, another British record. Transactions of the British Mycological Society 86, 329-351.

Ren F, Zhuang WY. 2014a - A new species of the genus Chlorencoelia (Helotiales) from China. Mycoscience 55, 227-230.

Ren F, Zhuang WY. 2014b - The genus Chlorociboria (Helotiales, Ascomycota) in China. Mycosystema 33, 916-24.

Rice AV, Currah RS. 2006 - Two new species of Pseudogymnoascus with Geomyces anamorphs and their phylogenetic relationship with Gymnostellatospora. Mycologia 98, 307-318.

Robinson SC. 2012 - Developing fungal pigments for "painting" vascular plants. Applied Microbiology and Biotechnology 93, 1389-1394.

Robinson SC, Tudor D, Cooper PA. 2012 - Utilizing pigment-producing fungi to add commercial value to American beech (Fagus grandifolia). Applied Microbiology and Biotechnology 93, 1041-1048.

Robinson SC, Weber G, Hinsch E, Vega-Gutierrez SM et al. 2014 - Utilizing extracted fungal pigments for wood spalting: a comparison of induced fungal pigmentation to fungal dyeing. Journal of Coatings 2014, 1-8.

Romero J, Raya MC, Roca LF, Agustí-Brisach C et al. 2017 - Phenotypic, molecular and pathogenic characterization of Phlyctema vagabunda, causal agent of olive leprosy. Plant Pathology 67, 277-294.

Rossman AY, Aime MC, Farr DF, Castlebury LA et al. 2004 - The coelomycetous genera Chaetomella and Pilidium represent a newly discovered lineage of inoperculate discomycetes. Mycological Progress 3, 275-290.

Rossman AY, Allen WC, Castlebury LA, Verkley G. 2018 - Three new combinations in Drepanopeziza for species on poplar. Mycotaxon 132, 951-955.

Saikawa Y, Watanabe T, Hashimoto K, Nakata M. 2000 - Absolute configuration and tautomeric structure of xylindein, a blue-green pigment of Chlorociboria species. Phytochemistry 55, 237-240.

Saito I, Kaji K. 2006 - Ciborinia gentianae sp. nov., the causal organism of sclerotial flower blight of cut-flower gentians. Mycoscience 47, 41-47.

Salgado-Salazar C, Beirn LA, Ismaiel A, Boehm MJ et al. 2018 - Clarireedia: A new fungal genus comprising four pathogenic species responsible for dollar spot disease of turfgrass. Fungal Biology 122, 761-773.

Samuels GJ, Hartill WFT, Tompkins G, Cheah LH. 1981 - Ascomycetes of New Zealand 2. Leptotrochilaporri parasitic on leek (Alliumporrum). New Zealand Journal of Botany 19, 131-135.

Sánchez A. 1967 - The Sections Apostemium and Microstemium of the Genus Vibrissea (Fungi). The Journal of Agriculture of the University of Puerto Rico 1, 79-93.

Sánchez A, Korf RP. 1966 - The Genus Vibrissea, and the Generic Names Leptosporium, Apostemium, Apostemidium, Gorgoniceps and Ophiogloea. Mycologia 58, 722-737. 
Šandová M, Nilsson RH, Kolařík M. 2018 - Relationships within Capitotricha bicolor (Lachnaceae, Ascomycota) as inferred from ITS rDNA sequences, including some notes on the Brunnipila and Erioscyphella clades. Mycological Progress 17, 89-101.

Sandoval-Leiva P, Carmaran CC, Park D, Romero AI, Johnston PR. 2014 - Vibrisseaceous fungi from the southern hemisphere, including Chlorovibrissea chilensis (Helotiales, incertaesedis) sp. nov. Mycologia 106, 1159-1167.

Sanoamuang N, Jitjak W, Rodtong S, Whalley AJ. 2013 - Gelatinomyces siamensis gen. sp. nov. (Ascomycota, Leotiomycetes, incertae sedis) on bamboo in Thailand. IMA Fungus 4, 71-87.

Sati SC, Pathak R. 2016 - Anamorph (asexual stage) Teleomorph (sexual stage) Connections in Aquatic hyphomycetes. The International Journal of Plant Reproductive Biology 8, 128-135.

Schüepp H. 1959 - Untersuchungen uber Pseudopezizoideae sensu Nannfeldt. Phytopathologische Ze itschrift 36, 213-269.

Schumacher T, Holst-Jensen A. 1997- A synopsis of the genus Scleromitrula (= Verpatinia) (Ascomycotina: Helotiales: Sclerotiniaceae). Mycoscience 38, 55-69.

Schumacher T, Kohn LM. 1985 - A monographic revision of the genus Myriosclerotinia. Canadian Journal of Botany 63, 1610-1640.

Seaver FJ. 1946 - Photographs and Descriptions of Cup-Fungi XLII. Gorgoniceps. Mycologia 38, $548-553$.

Seaver FJ. 1938 - Photographs and Descriptions of Cup-Fungi. XXIX Chloroscypha. Mycologia 30, 594-596.

Seephueak P, Petcharat V, Phongpaichit S. 2010 - Fungi associated with leaf litter of para rubber (Hevea brasiliensis). Mycology 1, 213-227.

Seifert KA, Carpenter SE. 1987 - Bisporella resinicola comb. nov. and its Eustilbum anamorph. Canadian Journal of Botany 65, 1262-1267.

Seifert KA, Hughes SJ, Boulay H, Louis-Seize G. 2007 - Taxonomy, nomenclature and phylogeny of three cladosporium-like hyphomycetes, Sorocybe resinae, Seifertia azaleae and the Hormoconis anamorph of Amorphotheca resinae. Studies in Mycology 58, 235-245.

Sharifi K, Davari M, Khodaparast SA, Bagheri-Kheirabadi M. 2014 - A Study on the identification of powdery mildew fungi (Erysiphaceae) in Ardabil landscape, Iran. Journal of Crop Protection 3, 663-671.

Shenoy BD, Jeewon R, Wang H, Amandeep K et al. 2010 - Sequence data reveals phylogenetic affinities of fungal anamorphs Bahusutrabeeja, Diplococcium, Natarajania, Paliphora, Polyschema, Rattania and Spadicoides. Fungal Diversity 44, 161-169.

Sherwood MA. 1980 - Taxonomic studies in the Phacidiales: the genus Coccomyces (Rhytismataceae). Occasional Papers. Farlovv Herharitun of Cryptogamic Botany. Harvard University $15,1-120$.

Shoji T. 1985 - Studies on the Chloroscypha needle blight of Japanese Cedar (Cryptomeria japonica D. DON) caused by Chloroscypha seaveri (III) Cultural characteristics of mycelial colonies of Chloroscypha seaveri. Journal of the Japanese Forest Society 67, 285-288.

Sieber TN, Kowalski TA. 1993 - The anamorphs of Grovesiella abieticola. Mycologia 85, 653659.

Sigler L, Lumley TC, Currah RS. 2000 - New species and records of saprophytic ascomycetes (Myxotrichaceae) from decaying logs in the boreal forest. Mycoscience 41, 495-502.

Singhr N, Tewar VP. 1977 - A new species of Moellerodiscus from India. Canadian Journal of Botany 55, 1646-1649.

Smerlis E. 1966 - Notes on the nomenclature of Nothophacidium phyllophilum Comb. Nov., its pathogenicity and relationship to Pezizella minuta. Canadian Journal of Botany 44, 563-565.

Smith AL 1901 - On some fungi from the West Indies. Journal of the Linnean Society 35, 1-19.

Soca-Chafre G, Rivera-Orduna FN, Hidalgo-Lara ME, Hernandez-Rodriguez C et al. 2011 Molecular phylogeny and paclitaxel screening of fungal endophytes from Taxus globosa. Fungal Biology 115, 143-156. 
Somrithipol S, Jones EG, Bahkali AH, Suetrong S et al. 2017 - Lauriomyces, a New Lineage in the Leotiomycetes with Three New Species. Cryptogamie Mycologie, 38, 259-273.

Somrithipol S, Kosol S, Jones EBG. 2006 - Lauriomyces sakaeratensis sp. nov., a new hyphomycete on decaying Dipterocarpus costatus fruits from Sakaerat Biosphere Reserve, Thailand. Nova Hedwigia 82, 209-215.

Song J, Liu L, Li Y, Hou C. 2012 - Two new species of Terriera from Yunnan Province, China. Mycotaxon 119, 329-335.

Spegazzini C. 1887 - Fungi Patagonici. Boletín de la Academia Nacional de Ciencias en Córdoba $11,5-64$.

Spiers AG, Hopcroft DH. 1998 - Morphology of Drepanopeziza species pathogenic to poplars. Mycological Research 102, 1025-1037.

Spooner BM. 1987 - Helotiales of Australasia: Geoglossaceae, Orbiliaceae, Scelrotiniaceae, Hyaloscyphaceae. Bibliotheca Mycologica 116, 1-711.

Spooren M. 2014 - A new species of Bloxamia from freshwater in the Netherlands. Mycosphere 5, 346-349.

Spribille T, Pérez-Ortega S, Tønsberg T, Schirokauer D. 2010 - Lichens and lichenicolous fungi of the Klondike Gold Rush National Historic Park, Alaska, in a global biodiversity context. The Bryologist 113, 439-515.

Sri-Indrasutdhi V, Tsui CK, Chuaseeharonnachai C, Yamaguchi K, Suetrong S et al. 2015 Helicocentralis hyalina gen. et sp. nov., an aero-aquatic helicosporous fungus (Leotiomycetes, Ascomycota) in Thailand. Mycological Progress 14, 81-92.

Stamatakis A. 2014 - RAxML version 8: a tool for phylogenetic analysis and post-analysis of large phylogenies. Bioinformatics 30, 1312-1313.

Stchigel AM, Josep CA, Mac Cormack W, Guarro J. 2001-Antarctomyces psychrotrophicus gen. et sp. nov., a new ascomycete from Antarctica. Mycological Research 105, 377-382.

Stenroos S, Laukka T, Huhtinen S, Döbbeler P et al. 2010 - Multiple origins of symbioses between ascomycetes and bryophytes suggested by a five-gene phylogeny. Cladistics 26, 281-300.

Stoykov DY, Assyov B. 2009 - The genus Trochila in Bulgaria. Mycotaxon 109, 351-359.

Stone JK, Gernandt DS. 2005 - A reassessment of Hemiphacidium, Rhabdocline, and Sarcotrochila (Hemiphacidiaceae). Mycotaxon 91, 115-126.

Strømeng GM, Stensvand A. 2011 - Godronia Canker (Godronia cassandrae f. sp. vaccinii) in Highbush blueberry. The European Journal of Plant Science and Biotechnology 5, 35-41.

Suh SO, Blackwell M. 1999 - Molecular Phylogeny of the Cleistothecial Fungi Placed in Cephalothecaceae and Pseudeurotiaceae. Mycologia 91, 836-848.

Suija A, van den Boom P, Zimmermann E, Zhurbenko MP, Diederich P. 2017 - Lichenicolous species of Hainesia belong to Phacidiales (Leotiomycetes) and are included in an extended concept of Epithamnolia. Mycologia 109, 882-899.

Suija A, Ertz D, Lawrey JD, Diederich P. 2014 - Multiple origin of the lichenicolous life habit in Helotiales, based on nuclear ribosomal sequences. Fungal Diversity 70, 55-72.

Suková M. 2005 - A revision of selected material of lignicolous species of Brunnipila, Capitotricha, Dasyscyphella and Neodasyscypha from the Czech Republic. Czech Mycology 57, 139-172.

Sutton BC, Ganapathi A. 1978 - Trimmatostroma excentricum sp.nov., on Eucalyptus from New Zealand and Fiji. New Zealand Journal of Botany16, 529-533.

Sutton BC, Hennebert GL. 1995 - Interconnections amongst anamorphs and their possible contribution to ascomycetes systematics. In: Hawksworth DL (ed) Ascomycete systematics: problems and perspectives in the nineties. Plenum, New York, pp 77-100.

Sutton BC. 1980 - The Coelomycetes. Commonwealth Mycological Institute, UK.

Svrček M. 1976 - New or less known Discomycetes. III. Česká Mykologie 30, 8-16

Svrcek M. 1977a - New or less known Discomycetes. V. Ceská Mykologie 31, 132-138

Svrcek M. 1977b - New or less known Discomycetes. VI. Ceská Mykologie 31, 193-200

Svrček M. 1982 - New or less known Discomycetes XI. Česká Mykologie 36, 146-153 
Sydow H. 1924 - Beiträge zur Kenntnis der Pilzflora Neu-Seelands. Annales Mycologici 22, 293317

Tai FL. 1979 - Sylloge Fungorum Sinicorum. Beijing, Science Press.

Takamatsu S. 2004 - Phylogeny and evolution of the powdery mildew fungi (Erysiphales, Ascomycota) inferred from nuclear ribosomal DNA sequences. Mycoscience 45, 147-157.

Takamatsu S, Ito H, Shiroya Y, Kiss L, Heluta V. 2015 - First comprehensive phylogenetic analysis of the genus Erysiphe (Erysiphales, Erysiphaceae) I. The Microsphaera lineage. Mycologia 107, 475-89.

Tanney JB, Seifert KA. 2018 - Phacidiaceae endophytes of Picea rubens in Eastern Canada. Botany 96, 555-588.

Tanney JB, Seifert KA. 2017 - Lophodermium resinosum sp. nov. from red pine (Pinus resinosa) in Eastern Canada. Botany 95, 773-784.

Tedersoo L, Pärtel K, Jairus T, Gates G, Põldmaa K, Tamm H. 2009 - Ascomycetes associated with ectomycorrhizas: molecular diversity and ecology with particular reference to the Helotiales. Environmental Microbiology 11, 3166-3179.

Tehon LR. 1935 - A monographic rearrangement of Lophodermium. Illinois Biology Monographs $13,1-151$.

Travadon R, Lawrence DP, Rooney-Latham S, Gubler WD et al. 2015 - Cadophora species associated with wood-decay of grapevine in North America. Fungal Biology 119, 53-66.

Tsuneda A, Currah RS. 2004 - Ascomatal morphogenesis in Myxotrichum arcticum supports the derivation of the Myxotrichaceae from a discomycetous ancestor. Mycologia 96, 627-635.

U'Ren JM, Lutzoni F, Miadlkowska J, Arnold AE. 2010 - Community analysis reveals close affinities between endophytic and endolichenic fungi in mosses and lichens. Microbial Ecology 60, 340-353.

Vera DI, Murray TD. 2016 - Occurrence and Survival of Apothecia of the Eyespot Pathogens Oculimacula acuformis and O. yallundae on Wheat Stubble in the U.S. Pacific Northwest. Plant Disease 100, 991-995.

Verkley GJM. 1992 - Ultrastructure of the ascus apical apparatus in Ombrophila violacea, Neobulgaria pura and Bulgaria inquinans (Leotiales). Persoonia 15, 3-22.

Verkley, G.J.M. 1993 - Ultrastructure of the ascus apical apparatus in ten species of Sclerotiniaceae. Mycological Research 97, 179-194.

Verkley GJM. 1995 - Ultrastructure of the ascus apical apparatus in species of Cenangium, Encoelia, Claussenomyces and Ascocoryne. Mycological Research 99, 187-199.

Verkley GJM. 1999 - A monograph of the genus Pezicula and its anamorphs. Studies in Mycology $44,1-180$.

Verkley GJM. 2001 - On Sphaerographium petiolicola and a new species, S. tenuirostrum, taxa from a rarely collected genus of coelomycetes. Mycologia 93, 205-211.

Verkley GJM. 2002 - A revision of the genus Sphaerographium and the taxa assigned to Rhynchophoma (anamorphic Ascomycetes). Nova Hedwigia 75, 433-450.

Verkley GJM. 2005 - Brefeldochium pruinosum, gen. et sp. nov., the anamorph of Polydesmia pruinosa (Hyaloscyphaceae, Helotiales, Ascomycota). Nova Hedwigia 80, 503-509.

Verkley GJM, Hofland-Zijlstra JD, Berendse F. 2010 - Rhizodermea veluwensis. Fungal Planet 46. Persoonia 24, 130-131.

Vilgalys R, Hester M. 1990 - Rapid genetic identification and mapping of enzymatically amplified ribosomal DNA from several Cryptococcus species. Journal of Bacteriology 172, 4238-4246.

Villesen P 2007 - FaBox: an online toolbox for fasta sequences. Molecular Ecology Notes 7, 965968.

Voglmayr H. 2004 - Spirosphaera cupreorufescens sp. nov., a rare aeroaquatic fungus. Studies in Mycology 50, 221-228.

Walsh E, Luo J, Zhang N. 2014 - Acidomelania panicicola gen. et sp. nov. from switchgrass roots in acidic New Jersey pine barrens. Mycologia 106, 856-864. 
Walsh E, Duan W, Mehdi M, Naphri K. 2018 - Cadophora meredithiae and C. interclivum, new species from roots of sedge and spruce in a western Canada subalpine forest. Mycologia 110, 201-214.

Wang YZ. 2009 - A new species of Arachnopeziza from Taiwan. Mycotaxon 108, 485-489.

Wang YZ. 2007 - Chlorosplenium chlora, a discomycete new to Taiwan. Fungal Science 22, 5962 .

Wang Z, Binder M, Hibbett DS. 2005 - Life history and systematics of the aquatic discomycete Mitrula (Helotiales, Ascomycota) based on cultural, morphological, and molecular studies. American Journal of Botany 92, 1565-1574.

Wang Z, Binder M, Schoch CL, Johnston PR et al. 2006a - Evolution of helotialean fungi (Leotiomycetes, Pezizomycotina): a nuclear rDNA phylogeny. Molecular Phylogenetic and Evolution 41, 295-312.

Wang Z, Johnston PR, Takamatsu S, Spatafora JW et al. 2006b - Towards a phylogenetic classification of the Leotiomycetes based on rDNA data. Mycologia 98, 1065-1075.

Wang Z, Binder M, Hibbett DS. 2002 - A new species of Cudonia based on morphological and molecular data. Mycologia 94, 641-650.

Wang W, McGhee D, Gibas CFC, Tsuneda A, Currah RS. 2009 - Phialocephala urceolata, sp. nov. from a commercial, water-soluble heparin solution. Mycologia 101, 136-141.

Warming E. 1884 - Haandbog i den systematiske Botanik. ed. 2. 1-434.

White TJ, Bruns T, Lee S, Taylor J. 1990 - Amplification and direct sequencing of fungal ribosomal RNA genes for phylogenetics. In: Innis MA, Gelfand DH, Sninsky JJ, White TJ (eds) PCR protocols: a guide to methods and applications. Academic Press, San Diego.

White WL. 1942 - A new hemiascomycete. Canadian Journal of Research 20, 389-395.

Wijayawardene NN, Hyde KD, Lumbsch HT, Liu JK et al. 2018 - Outline of Ascomycota: 2017. Fungal Diversity 88, 167-263.

Xiao C, Rogers J, Kim Y, Liu Q. 2005 - Phacidiopycnis washingtonensis - a new species associated with pome fruits from Washington State. Mycologia 97, 464-473.

Yang ZZ, Lin YR, Hou CL. 2011 - A new species of Terriera (Rhytismatales, Ascomycota) from China. Mycotaxon 117, 367-371.

Yao YJ, Spooner BM. 1999 - Roesleriaceae, a new family of Ascomycota, and a new species of Roesleria. Kew Bulletin 54, 683-693.

Ye M, Cao SQ, Jiang ST, Pan LJ et al. 2006 - Species diversity of Lachnum (Helotiales, Hyaloscyphaceae) from temperate China. Journal of Zheijang University 7, 20-27.

Yoshikawa M, Yokoyama T. 1992 - Thedgonia ligustrina on Ligustrum japonicum and Cercospora kyotensis, new species on Hydrangea serrata var. thunbergii. Transactions of the Mycological Society of Japan 33, 177-184.

Yuan C, Guo YH, Wang HY, Ma XJ, Jiang T, Zhao JL, Zou ZM, Ding G. 2016 - Allelopathic Polyketides from an Endolichenic Fungus Myxotrichum sp. by Using OSMAC Strategy. Scientific Reports 6, 19350.

Yuan Z, Verkley GJM. 2015 - Pezicula neosporulosa sp. nov. (Helotiales, Ascomycota), an endophytic fungus associated with Abies spp. in China and Europe. Mycoscience 56, 205213.

Zhang TT, Tong X, Lin YR, Hou CL. 2015 - A new species and a new combination of Terriera based on morphological and molecular data. Mycological Progress 14, 54-59.

Zhao YJ, Hosaka K, Hosoya T. 2016 - Taxonomic re-evaluation of the genus Lambertella (Rutstroemiaceae, Helotiales) and allied stroma-forming fungi. Mycological Progress 15, $1215-1228$.

Zhao YJ, Hosoya T, Shirouzu T, Kakishima M, Yamaoka Y. 2013 - Lambertella pyrolae, a new rutstroemiaceous fungus from Japan. Phytotaxa 136, 54-60.

Zhaxybayeva O, Gogarten JP. 2002 - Bootstrap, Bayesian probability and maximum likelihood mapping: exploring new tools for comparative genome analyses. BMC Genomics 3, 4-22. 
Zheng HD, Zhuang WY. 2013 - A new species of Roseodiscus (Ascomycota, Fungi) from tropical China. Phytotaxa 105, 51-57.

Zheng HD, Zhuang WY. 2015 - Four new species of Crocicreas (Helotiales, Leotiomycetes) from China. Ascomycete.org 7, 394-402.

Zheng HD, Zhuang WY. 2016 - Two new species of Crocicreas (Helotiaceae, Ascomycota) revealed by morphological and molecular data. Phytotaxa 272, 149-156.

Zheng HD, Zhuang WY. 2017a - Chlorovibrissea korfii sp. nov. from northern hemisphere and Vibrissea flavovirens new to China. MycoKeys 26, 1-11.

Zheng HD, Zhuang WY. 2017b - A new species of Chlorociboria (Helotiales, Ascomycota) on herbaceous stems from China. Phytotaxa 312, 111-117.

Zhu L, Wang X, Huang F, Zhang J et al. 2012 - A destructive new disease of Citrus in China caused by Cryptosporiopsis citricarpa sp. nov. Plant Disease 96, 804-812.

Zhuang WY, Zheng HD, Ren F. 2017 - Taxonomy of the genus Bisporella (Helotiales) in China with seven new species and four new records. Mycosystema 36, 401-420.

Zhuang WY. 1995 - A few petiole inhabiting Discomycetes in China. Mycosystema 7, 13-17.

Zhuang WY, Luo J \& Zhao P. 2010 - The fungal genus Calycellinopsis belongs in Helotiaceae not Dermateaceae. Phytotaxa 3: 54-58.

Zhuang WY, Liu CY. 2007 - Taxonomic reassessment of two taxa of helotialean fungi. Mycotaxon 99, 123-132.

Zhuang WY, Yu ZH. 2001 - Two new species of Perrotia (Helotiales, Hyaloscyphaceae) from tropical China and a key to the known species of the genus. Nova Hedwigia 71, 261-267.

Zhuang WY. 1988 - A new species of Dencoeliopsis and asynoptic key to the genera of the Encoelioideae (Leotiaceae). Mycotaxon 32, 97-104.

Zhurbenko M. 2007 - Corticifraga santessonii and C. chugachiana (Lecanoromycetes, Ascomycota), new species of lichenicolous fungi from the Holarctic. Lichenologist 39, 221226.

Zhurbenko MP. 2012 - Lichenicolous fungi growing on Thamnolia, mainly from the Holarctic, with a worldwide key to the known species. Lichenologist 44, 147-177

Zhurbenko MP, Pino-Bodas R. 2017 - A revision of lichenicolous fungi growing on Cladonia, mainly from the Northern Hemisphere, with a worldwide key to the known species. Opuscula Philolichenum 16, 188-266. 
Supplementary Table 1 GenBank accession number and other information of strains used in phylogenetic analysis of Back-bone tree for Leotiomycetes of this study (Newly generated sequences are in bold).

\begin{tabular}{|c|c|c|c|c|c|c|}
\hline Species & Isolate & LSU & ITS & SSU & TEF & RPB2 \\
\hline Arachnopeziza aurata & KUS_F52038 & JN086696 & JN033393 & - & - & JN086847 \\
\hline Arachnopeziza obtusipila & TNS_F12769 & JN086747 & JN033446 & - & - & JN086891 \\
\hline Eriopezia caesia & SBRH 843 & KX501130 & KX501126 & - & - & - \\
\hline Parachnopeziza guangxiensis & & - & - & AY120864 & - & - \\
\hline Calloria urticae & G.M. 2015_05_10 & - & KT185668 & - & - & - \\
\hline Duebenia compta & G.M. 2015_06_01_1 & - & KY462820 & - & - & - \\
\hline Laetinaevia carneoflavida & G.M. 2014_07_25 & - & KT185666 & - & - & - \\
\hline Naevala minutissima & CBS 115920 & - & AY853229 & - & - & - \\
\hline Ameghiniella australis & KL391 & KX090841 & - & KX090893 & KX090690 & - \\
\hline Cordierites frondosa & HKAS41508 & AY789354 & AY789355 & AY789353 & - & - \\
\hline Diplocarpa bloxamii & KL317 & KX090834 & - & KX090885 & KX090688 & KX090745 \\
\hline Diplolaeviopsis ranula & NBM FL_14388 & KP984785 & KP984782 & - & - & - \\
\hline Ionomidotis fulvotingens & KL239 & KX138407 & - & KX138403 & - & KX138401 \\
\hline Ionomidotis fulvotingens & G.M. 2015_03_31 & - & KY462808 & - & - & - \\
\hline Llimoniella terricola & LL95 & KX090842 & - & KX090895 & KX090693 & KX090741 \\
\hline Llimoniella gregorellae & Vondrak 8374 & KJ559569 & KJ559547 & KJ559589 & - & - \\
\hline Rhymbocarpus fuscoatrae & Ertz 16200 & KJ559571 & KJ559549 & KJ559593 & - & - \\
\hline Skyttea lecanorae & NY1595972 & KJ559561 & KJ559539 & - & - & - \\
\hline Thamnogalla crombiei & Diederich 17315 & KJ559578 & KJ559550 & KJ559594 & - & - \\
\hline Unguiculariopsis lettaui & Ertz 16346 & KJ559579 & KJ559548 & KJ559592 & - & - \\
\hline Chlorociboria cf. aeruginosa & AFTOL_ID 151 & AY544669 & DQ491501 & AY544713 & DQ471053 & DQ470886 \\
\hline Chlorociboria awakinoana & D1549 & JN939922 & - & - & - & - \\
\hline Angelina rufescens & JK 12040101 & JX624162 & - & - & - & - \\
\hline Dermea acerina & AFTOL_ID 941 & DQ247801 & - & DQ247809 & DQ471091 & DQ247791 \\
\hline Dermea acerina & CBS161.38 & DQ247801 & AF141164 & DQ247809 & - & - \\
\hline
\end{tabular}


Supplementary Table 1 Continued.

\begin{tabular}{|c|c|c|c|c|c|c|}
\hline Species & Isolate & LSU & ITS & SSU & TEF & RPB2 \\
\hline Neofabraea malicorticis & CBS 102863 & KR858876 & KR859085 & - & KX982708 & KR859325 \\
\hline Pezicula cinnamomea & CBS 240.96 & KR858916 & KF376105 & - & KF376265 & KF376163 \\
\hline Blumeriella kerriae & JS20160615 & - & KY929501 & - & - & - \\
\hline Diplocarpon rosae & DR_19 & - & KP052773 & - & - & - \\
\hline Marssonina coronariae & NL1 & - & KY672995 & - & - & - \\
\hline Pseudopeziza medicaginis & Ap1 & - & EU729125 & - & - & - \\
\hline Thedgonia ligustrina & CBS:132025 & GU253856 & GU269839 & - & GU384552 & - \\
\hline Ascocalyx abietina & ATCC 28379 & - & AF260815 & - & - & - \\
\hline Godronia cassandrae & DAOM 233255 & - & EF672239 & - & - & - \\
\hline Gremmeniella laricina & 81_857 & - & KC352997 & - & - & KC533140 \\
\hline Ascocoryne cylichnium & KUS_F52351 & JN086709 & JN033406 & - & - & - \\
\hline Ascotremella faginea & GM_2015_10_28 & - & KY462798 & - & - & - \\
\hline Chloroscypha cf. enterochroma & AFTOL_ID 67 & AY544656 & - & AY544700 & - & - \\
\hline Chlorociboria awakinoana & D1549 & JN939922 & U92312 & JN939869 & - & JN985503 \\
\hline Neobulgaria lilacina & M258 & EU940141 & EU940217 & EU940066 & - & EU940352 \\
\hline Ombrophila violacea & WZ0024 & AY789365 & AY789366 & AY789364 & - & - \\
\hline Xerombrophila crystallifera & CBS 128289 & - & JX454953 & - & - & - \\
\hline Neocudoniella radicella & UAMH 5794 & - & NR_121301 & - & - & - \\
\hline Bisporella citrina & M253 & EU940087 & EU940164 & EU940014 & - & EU940303 \\
\hline Bisporella shangrilana & HMAS 275568 & - & NR_153628 & - & - & - \\
\hline Bryoscyphus dicrani & M141 & EU940107 & EU940183 & EU940034 & - & EU940323 \\
\hline Cudoniella clavus & AFTOL_ID 166 & DQ470944 & DQ491502 & DQ470992 & DQ471056 & DQ470888 \\
\hline Cyathicula microspora & M267 & EU940088 & EU940165 & EU940015 & - & EU940304 \\
\hline Dicephalospora rufocornea & KUS_F52274 & JN086704 & JN033401 & - & - & JN086855 \\
\hline Graddonia coracina & ILLS60491 & JN012009 & JQ256423 & - & - & - \\
\hline Hymenoscyphus pseudoalbidus & Hokk_14 & - & KJ511191 & - & - & - \\
\hline
\end{tabular}


Supplementary Table 1 Continued.

\begin{tabular}{|c|c|c|c|c|c|c|}
\hline Species & Isolate & LSU & ITS & SSU & TEF & RPB2 \\
\hline Hymenoscyphus occultus & KUS_F52847 & - & KP068064 & - & - & - \\
\hline Hymenotorrendiella madsenii & ICMP 15648 & KJ606676 & AY755336 & KJ606666 & - & - \\
\hline Hymenoscyphus ericae & UAMH6735 & - & AJ319078 & - & - & - \\
\hline Phaeohelotium geogenum & KL219 & KX090816 & - & KX090867 & KX090668 & KX090717 \\
\hline Phaeohelotium epiphyllum & TNS:F_40042 & AB926130 & AB926061 & - & - & AB926219 \\
\hline Tricladium obesum & CCM F_14598 & KC834035 & KC834068 & - & - & - \\
\hline Tricladium splendens & CCM F_16599 & GQ477333 & - & - & - & - \\
\hline Cenangiopsis quercicola & KL174 & KX090811 & LT158425 & KX090862 & KX090663 & KX090713 \\
\hline Cenangium acuum & KL276 & KX090828 & LT158445 & KX090879 & KX090680 & KX090727 \\
\hline Chlorencoelia versiformis & KL21 & KX090795 & LT158427 & KX090846 & - & - \\
\hline Crumenulopsis sororia & KL254 & KX090826 & LT158442 & - & - & KX090725 \\
\hline Didymascella thujina & Dd5_3a_800.SCF & - & KT875767 & - & - & - \\
\hline Encoelia furfuracea & KL107 & KX090798 & LT158416 & KX090850 & KX090653 & KX090701 \\
\hline Fabrella tsugae & & AF356694 & U92304 & AF106015 & - & - \\
\hline Heyderia abietis & HMAS71954 & AY789296 & AY789297 & AY789295 & - & - \\
\hline Pseudomitrula cf. & MES_2129 & - & KY462665 & - & - & - \\
\hline Rhabdocline parkeri & ATCC 201660 & - & AF260813 & - & - & - \\
\hline Sarcotrochila longispora & CBS 273.74 & KJ663877 & KJ663836 & - & - & KJ663918 \\
\hline Trochila laurocerasi & KL336 & KX090835 & LT158460 & KX090887 & KX090689 & KX090734 \\
\hline Velutarina alpestris & KL378 & KX090839 & LT158470 & KX090891 & - & KX090738 \\
\hline Heterosphaeria patella & G.M. 2014_08_04_1 & - & MF196187 & - & - & - \\
\hline Amicodisca sp. & KUS_F51377 & JN086692 & JN033389 & - & - & JN086843 \\
\hline Asperopilum juncicola & PRJ D456 & - & KP161274 & - & - & - \\
\hline Cistella albidolutea & KUS_F52678 & JN086732 & JN033429 & - & - & JN086872 \\
\hline Dematioscypha dematiicola & TNS_F_17834 & JN086739 & JN033438 & - & - & JN086883 \\
\hline Endoscypha perforans & PDD:102231 & - & KF727424 & - & - & - \\
\hline
\end{tabular}


Supplementary Table 1 Continued.

\begin{tabular}{|c|c|c|c|c|c|c|}
\hline Species & Isolate & LSU & ITS & SSU & TEF & RPB2 \\
\hline Fuscolachnum misellum & SBRH 799b & KX501129 & KX501124 & - & - & - \\
\hline Hyalopeziza pygmaea & TNS_F17940 & JN086748 & JN033448 & - & - & JN086894 \\
\hline Hyaloscypha monodictys & TNS_F5013 & JN086756 & JN033456 & - & - & JN086906 \\
\hline Hyaloscypha hepaticola & M339 & EU940150 & EU940226 & EU940074 & - & EU940359 \\
\hline Hyaloscypha albohyalina & M259 & EU940151 & EU940227 & EU940075 & - & EU940360 \\
\hline Hyphodiscus hymeniophilus & TNS_F31801 & AB546946 & AB546948 & - & - & JN086901 \\
\hline Olla millepunctata & KACC45226 & JN086683 & JN033380 & - & - & JN086835 \\
\hline Unguicularia unguiculata & NK322 & - & HG326612 & HG326613 & - & - \\
\hline Urceolella carestiana & TNS_F18014 & JN086744 & JN033443 & - & - & JN086888 \\
\hline Venturiocistella japonica & TNS_F18030 & AB546954 & JN033447 & - & - & JN086893 \\
\hline Albotricha sp. & FC_2190 & $\mathrm{AB} 481310$ & $\mathrm{AB} 481237$ & - & - & $\mathrm{AB} 481347$ \\
\hline Brunnipila fuscescens & KUS_F52031 & JN086695 & JN033392 & - & - & JN086846 \\
\hline Dasyscyphella montana & FC_2070 & AB481299 & $\mathrm{AB} 481242$ & - & - & AB481336 \\
\hline Erioscyphella lunata & S.T. 13021602 & KX501133 & KX501132 & - & - & - \\
\hline Incrucipulum longispineum & FC_2323 & $\mathrm{AB} 481325$ & $\mathrm{AB} 481256$ & - & - & $\mathrm{AB} 481362$ \\
\hline Lachnellula occidentalis & FC_2034 & AB481296 & $\mathrm{AB} 481244$ & - & - & AB481333 \\
\hline Lachnum fuscescens & FC_2200 & $\mathrm{AB} 481311$ & $\mathrm{AB} 481255$ & - & - & $\mathrm{AB} 481348$ \\
\hline Lasiobelonium lonicerae & FC_2270 & AB481319 & $\mathrm{AB} 481284$ & - & - & $\mathrm{AB} 481356$ \\
\hline Neodasyscypha cerina & & - & U57812 & - & - & - \\
\hline Perrotia populina & KL120 & KX090802 & - & KX090854 & KX090656 & KX090705 \\
\hline Proliferodiscus sp. & KUS_F52660 & JN086730 & JN033427 & - & - & JN086871 \\
\hline Solenopezia solenia & G_fon 1 & - & KY592188 & - & - & - \\
\hline Trichopeziza sulphurea & KUS_F52218 & JN086701 & JN033398 & - & - & JN086852 \\
\hline Trichopezizella otanii & FC_2156 & $\mathrm{AB} 481307$ & $\mathrm{AB} 481287$ & - & - & $\mathrm{AB} 481345$ \\
\hline Loramyces macrosporus & AFTOL_ID 913 & DQ470957 & JN033383 & DQ471005 & DQ471076 & DQ470907 \\
\hline Mitrula brevispora & ZW02_012 & AY789293 & AY789294 & AY789292 & - & - \\
\hline
\end{tabular}


Supplementary Table 1 Continued.

\begin{tabular}{|c|c|c|c|c|c|c|}
\hline Species & Isolate & LSU & ITS & SSU & TEF & RPB2 \\
\hline Mollisia cinerea & AFTOL_ID 76 & DQ470942 & DQ491498 & DQ470990 & DQ471051 & DQ470883 \\
\hline Mollisia ventosa & KUS_F52181 & JN086700 & JN033397 & - & - & JN086851 \\
\hline Acephala applanata & CBS 109321 & KF951051 & NR_119482 & KT259197 & - & - \\
\hline Phialocephala urceolata & UAMH 10827 & - & NR_111285 & EU155146 & - & - \\
\hline Phialocephala scopiformis & CBS 468.94 & - & NR_119460 & - & - & - \\
\hline Tapesia fusca & ARON3154.H & - & AJ430229 & - & - & - \\
\hline Calycellina populina & CBS:247.62 & JN086685 & JN033382 & - & - & JN086837 \\
\hline Calycina marina & TROM:F26101 & KT185671 & KT185674 & - & - & - \\
\hline Ciliolarina pinicola & G.M. 2014_11_10.3 & - & KY800411 & - & - & - \\
\hline Hamatocanthoscypha laricionis & TNS_F13530 & JN086742 & JN033441 & - & - & JN086886 \\
\hline Microscypha sp. & TNS_F18016 & JN086745 & JN033444 & - & - & JN086889 \\
\hline Mollisina uncinata & KUS_F52307 & JN086707 & JN033404 & - & - & JN086858 \\
\hline Psilachnum staphyleae & KUS_F52105 & JN086699 & JN033396 & - & - & JN086850 \\
\hline Rodwayella citrinula & KUS_F52443 & JN086717 & JN033414 & - & - & JN086862 \\
\hline Scleropezicula alnicola & CBS474.97 & - & AF141169 & - & - & - \\
\hline Oculimacula yallundae & TN 401 & - & KF977547 & - & - & - \\
\hline Pirottaea palmicola & PDD:60282 & - & KM677208 & - & - & - \\
\hline Pyrenopeziza sp. & KUS_F52417 & JN086716 & JN033413 & - & - & - \\
\hline Pyrenopeziza velebitica & CNF 2_10097 & NG_060837 & MF593628 & - & - & - \\
\hline Cadophora viticola & Cme_3 & - & HQ661098 & - & HQ661083 & - \\
\hline Cadophora antarctica & FMR16056 & MG385663 & MG385664 & - & - & - \\
\hline Ypsilina graminea & UMB_111.01 & - & GQ411306 & - & - & - \\
\hline Roesleria subterranea & CBS 339.96 & EF608074 & EF060308 & - & - & - \\
\hline Bicornispora seditiosa & $\mathrm{AH} 44702$ & KF499362 & KF499362 & - & - & - \\
\hline Lambertella palmeri & AH 7576 & KF499364 & KF499364 & - & - & - \\
\hline Lanzia berggrenii & ICMP:19614 & KC164640 & KC164645 & KC164670 & - & - \\
\hline
\end{tabular}


Supplementary Table 1 Continued.

\begin{tabular}{|c|c|c|c|c|c|c|}
\hline Species & Isolate & LSU & ITS & SSU & TEF & RPB2 \\
\hline Rutstroemia longipes & TNS:F_40097 & AB926142 & AB926073 & - & - & AB926187 \\
\hline Torrendiella eucalypti & CPC 11050 & DQ195800 & DQ195788 & DQ195811 & - & - \\
\hline Botrytis sinoallii & LeekBC_18 & - & FJ169673 & - & - & FJ169679 \\
\hline Ciboria shiraiana & KUS_F52447 & JN086733 & JN033430 & - & - & JN086873 \\
\hline Ciborinia camelliae & TNS:F_40102 & AB926159 & AB926074 & - & - & AB926207 \\
\hline Coprotinia minutula & 1916.P & Z81405 & Z81428 & - & - & - \\
\hline Cristulariella depraedans & KUS_F25920 & KX098505 & KT462571 & - & - & - \\
\hline Dumontinia tuberosa & TNS:F_40114 & AB926161 & AB926077 & - & - & AB926215 \\
\hline Elliottinia kerneri & KL402 & - & LT158475 & - & - & - \\
\hline Grovesinia moricola & KUS_F26901 & KX098504 & KC460209 & - & - & - \\
\hline Haradamyces foliicola & MAFF 411026 & - & NR_137642 & AB329717 & - & - \\
\hline Kohninia linnaeicola & ARON_3887 & - & AY236424 & - & - & - \\
\hline Moellerodiscus pinicola & TNS:F_40115 & AB926162 & AB926078 & - & - & AB926192 \\
\hline Monilinia laxa & SK278 & - & LN714571 & - & - & LN714676 \\
\hline Mycopappus alni & KUS:F29393 & KY696724 & KY696717 & - & - & - \\
\hline Myriosclerotinia caricis & SCL14704 & KX670973 & KX574456 & - & - & - \\
\hline Piceomphale bulgarioides & LMK 102 & - & U21814 & - & - & - \\
\hline Pycnopeziza sejournei & KL267 & KX090827 & LT158443 & KX090878 & KX090679 & KX090726 \\
\hline Scleromitrula shiraiana & Hirayama062001 & AY789407 & AY789408 & AY789406 & - & - \\
\hline Sclerotinia nivalis & PSnS_R & KM265190 & KM265189 & - & - & - \\
\hline Septotinia populiperda & $\mathrm{S} 2 \_4$ & KF590142 & - & - & - & - \\
\hline Stromatinia cryptomeriae & TNS:F_40103 & AB926160 & AB926075 & - & - & AB926191 \\
\hline Valdensinia heterodoxa & 485.2 & Z81423 & Z81447 & Z81399 & - & - \\
\hline Chlorovibrissea sp. & PDD70070 & DQ257352 & DQ257353 & DQ257351 & - & - \\
\hline Vibrissea truncorum & AFTOL_ID 1322 & FJ176874 & - & FJ176818 & FJ238405 & FJ238356 \\
\hline Vibrissea flavovirens & MBH39316 & AY789426 & AY789427 & AY789425 & - & - \\
\hline
\end{tabular}


Supplementary Table 1 Continued.

\begin{tabular}{|c|c|c|c|c|c|c|}
\hline Species & Isolate & LSU & ITS & SSU & TEF & RPB2 \\
\hline Ascodichaena rugosa & Lantz 313 & HM140500 & - & - & - & - \\
\hline Chaetomella oblonga & BPI 843552 & AY487080 & AY487079 & AY487081 & - & - \\
\hline Pilidium acerinum & BPI 843555 & AY487092 & AY487091 & AY487093 & - & - \\
\hline Sphaerographium nyssicola & CBS 128284 & - & NR_119916 & - & - & - \\
\hline Synchaetomella acerina & DAOM 242271 & NG_042747 & NR_111811 & JX989832 & - & - \\
\hline Amylocarpus encephaloides & $017 \mathrm{cN}$ & KM272361 & KM272369 & - & - & - \\
\hline Banksiamyces sp. & PDD 105253 & - & KM880187 & - & - & - \\
\hline Belonioscyphella hypnorum & Bel2 & KU900906 & KU900903 & - & KU900910 & - \\
\hline Bulgariella pulla & DHP_06_607 & KJ704849 & KJ704848 & KJ704850 & - & - \\
\hline Calycellinopsis xishuangbanna & & KR094163 & - & GU936124 & - & - \\
\hline Cashiella sticheri & PDD:103198 & KF033117 & KF033116 & KF033118 & - & - \\
\hline Chlorosplenium chlora & BHI_F737a & - & MG553994 & - & - & - \\
\hline Chlorosplenium chlora isolate & BHI_F736a & MG553993 & MG553993 & - & - & - \\
\hline Colipila masduguana & CBS 128287 & HQ694501 & - & - & - & - \\
\hline Corticifraga peltigerae & G.M. 2015_05_02_1 & KY462801 & KY462801 & - & - & - \\
\hline Crocicreas cacaliae & F_148, 706 & FJ005126 & FJ005107 & - & - & - \\
\hline Leptodontidium trabinellum & CBS_329.53 & KY853509 & KY853449 & - & - & - \\
\hline Leptodontidium irregulare & CBS_851.73 & KY853508 & KY853448 & AY129281 & - & - \\
\hline Mitrulinia ushuaiae & PDD: 105643 & KX273439 & KX273438 & - & - & - \\
\hline Orbiliopsis callistea & PDD:97932 & HQ533050 & HQ533049 & - & - & - \\
\hline Patellariopsis atrovinosa & G.M. 2016_05_04.1 & KY970066 & KY970066 & KY970066 & - & - \\
\hline Patellariopsis atrovinosa voucher & G.M. 2014_06_15_1 & KY462814 & KY462814 & KY462814 & - & - \\
\hline Patinella hyalophaea & H.B. 9739 & - & KT876978 & - & - & - \\
\hline Peltigeromyces sp. & KL153 & KX090803 & - & KX090855 & - & KX090707 \\
\hline Polydesmia pruinosa & TNS_F12764 & JN086753 & JN033453 & - & - & JN086899 \\
\hline Roseodiscus subcarneus & D. Haelew. 314a & KT972715 & KT972714 & KT972713 & - & - \\
\hline
\end{tabular}


Supplementary Table 1 Continued.

\begin{tabular}{|c|c|c|c|c|c|c|}
\hline Species & Isolate & LSU & ITS & SSU & TEF & RPB2 \\
\hline Tetracladium ellipsoideum & MIDUI30 & KF768467 & - & - & KF768430 & - \\
\hline Tetracladium marchalianum & F_312 & - & FJ000360 & - & - & - \\
\hline Halenospora varia & G_ela3 & - & MF329638 & - & - & - \\
\hline Leotia lubrica & AFTOL_ID 1 & AY544644 & - & AY544687 & DQ471041 & DQ470876 \\
\hline Leotia lubrica & KKM 337 & KF836627 & KF836617 & - & - & - \\
\hline Microglossum aff. nudipes & SAV F_11285 & KX382869 & KX382859 & - & - & KX382887 \\
\hline Thuemenidium atropurpureum & ILLS 61044 & JQ256441 & JQ256427 & - & - & - \\
\hline Pezoloma sp. & NBRC 103659 & AB506026 & AB506027 & - & - & - \\
\hline Medeolaria farlowii & & GQ406807 & GQ406809 & GQ406808 & - & - \\
\hline Calloriopsis sp. & G.M. 2014_12_07.1 & - & MF322774 & - & - & - \\
\hline Eleutheromyces pseudosubulatus & CBS:458.88 & EU754162 & KJ710467 & EU754063 & - & - \\
\hline Gelatinipulvinella astraoeca & TRL 11234 & - & U72611 & - & - & - \\
\hline Gelatinopsis hysteropatellae & G.M.2015_10_27.2 & MF322772 & MF322772 & - & - & - \\
\hline Geltingia associata & Perez_Ortega 1039 & KJ559562 & KJ559540 & KJ559584 & - & - \\
\hline Allantophomopsiella pseudotsugae & CBS 841.91 & KJ663868 & KJ663829 & - & - & KJ663909 \\
\hline Allantophomopsis lycopodina & CBS 137782 & KR873264 & KR873230 & - & KR873305 & - \\
\hline Bulgaria inquinans & AFTOL_ID 916 & DQ470960 & - & DQ471008 & DQ471079 & DQ470910 \\
\hline Darkera picea & CPC 23897 & KM108397 & NR_132906 & KM108446 & KM108423 & - \\
\hline Gremmenia infestans & CBS 396.48 & KJ663876 & KM216393 & - & - & KJ663917 \\
\hline Lophophacidium dooksii & DAOM183323 & - & KF889652 & - & - & - \\
\hline Phacidium lacerum & CBS 400.81 & KJ663884 & KJ663843 & - & - & KJ663925 \\
\hline Phacidiopycnis sp. & ZLY_2010b & HM595597 & HM595538 & - & - & - \\
\hline Pseudophacidium ledi & CBS 377.59 & KJ663901 & KJ663860 & - & - & KJ663941 \\
\hline Claussenomyces sp. & PDD: 106298 & MG807388 & MG807392 & MG807389 & - & - \\
\hline Collophora hispanica & CBS 128568 & MH878014 & NR_111680 & - & - & - \\
\hline Grovesiella abieticola & SaFap2016ID_17 & - & KX358852 & - & - & - \\
\hline
\end{tabular}


Supplementary Table 1 Continued.

\begin{tabular}{|c|c|c|c|c|c|c|}
\hline Species & Isolate & LSU & ITS & SSU & TEF & RPB2 \\
\hline Holwaya mucida & B 700009352 & DQ257356 & DQ257357 & DQ257355 & - & - \\
\hline Mniaecia jungermanniae & M145 & EU940109 & EU940185 & EU940036 & - & EU940324 \\
\hline Mniaecia nivea & M167 & EU940115 & EU940188 & EU940042 & - & - \\
\hline Trizodia acrobia & M157 & EU940113 & EU940190 & EU940040 & - & EU940326 \\
\hline Trizodia acrobia & M160 & EU940114 & EU940191 & EU940041 & - & EU940327 \\
\hline Cudonia circinans & $\mathrm{C} 316$ & KC833182 & KC833156 & - & KC833349 & KC833275 \\
\hline Spathularia flavida & isolate C322 & KC833227 & KC833070 & - & KC833394 & - \\
\hline Cyclaneusma minus & NY199 & - & KJ406925 & - & - & - \\
\hline Mellitiosporium versicolor & Lantz 357 & HM140560 & - & - & - & - \\
\hline Naemacyclus fimbriatus & AFTOL_ID 1295 & FJ176867 & - & FJ176811 & FJ238399 & - \\
\hline Propolis farinosa & PRJ R1018 & KJ606675 & KJ606681 & KJ606668 & - & - \\
\hline Bifusella camelliae & HOU1094 & KF797447 & KF797435 & - & - & - \\
\hline Coccomyces strobi & AFTOL_ID 1250 & DQ470975 & - & DQ471027 & DQ471099 & DQ470929 \\
\hline Colpoma quercinum & Lantz 368 & HM140513 & - & - & - & - \\
\hline Colpoma quercinum & 22_39 & - & KX815492 & - & - & - \\
\hline Cryptomyces theae & FU30017 & KF797444 & KF797432 & - & - & - \\
\hline Davisomycella medusa & BPI842078 & - & AY465525 & - & - & - \\
\hline Discocainia nervalis & 1045 & KJ513473 & KJ507206 & - & - & - \\
\hline Duplicariella phyllodoces & Lantz 389 & HM140516 & - & - & - & - \\
\hline Elytroderma deformans & CBS 181.68 & - & AF203469 & AF203455 & - & - \\
\hline Hypoderma minteri & BJTC 201203 & JX232418 & NR_120173 & - & - & - \\
\hline Lirula macrospora & isolate 13 & HQ902152 & HQ902159 & - & - & - \\
\hline Lophodermella arcuata & BPI842080 & - & AY465518 & - & - & - \\
\hline Lophodermium gamundiae & ICMP 16802 & - & NR_119628 & - & - & - \\
\hline Marthamyces desmoschoeni & PRJ R908 & KJ606673 & KJ606679 & KJ606670 & - & - \\
\hline Meloderma desmazieresii & CBS 612.84 & - & AF203470 & AF203454 & - & - \\
\hline
\end{tabular}


Supplementary Table 1 Continued.

\begin{tabular}{|c|c|c|c|c|c|c|}
\hline Species & Isolate & LSU & ITS & SSU & TEF & RPB2 \\
\hline Nematococcomyces rhododendri & HOU 879A & KC312685 & - & - & - & - \\
\hline Ploioderma destruens & T33 & - & GU138756 & - & - & - \\
\hline Rhytisma acerinum & Hou et al. 203 & FJ495190 & GQ253100 & - & - & - \\
\hline Rhytisma huangshanense & Hou 564 & FJ495192 & GQ253101 & FJ495193 & - & - \\
\hline Soleella chinensis & R35 & - & GU138755 & - & - & - \\
\hline Sporomega degenerans & Lantz 367 & HM140567 & - & - & - & - \\
\hline Terriera elliptica & HOU327 & KP878550 & KP878549 & - & - & - \\
\hline Therrya abieticola & CNU447A & KP322579 & KP322573 & - & - & - \\
\hline Tryblidiopsis pinastri & AFTOL_ID 1319 & DQ470983 & - & DQ471035 & DQ471106 & DQ470935 \\
\hline Tryblidiopsis pinastri & BPI665552 & - & KF545364 & - & - & - \\
\hline Antarctomyces pellizariae & UFMGCB 12416 & - & KX576510 & - & - & KY100007 \\
\hline Ascozonus woolhopensis & & - & - & AF010590 & - & - \\
\hline Caccobius minusculus & ARO 2536 & - & - & AF010587 & - & - \\
\hline Cleistothelebolus nipigonensis & & KC492061 & KC492060 & - & - & - \\
\hline Thelebolus ellipsoideus & AFTOL_ID 5005 & FJ176895 & AY957550 & FJ176840 & - & FJ238378 \\
\hline Thelebolus globosus & AFTOL_ID 5016 & FJ176905 & - & FJ176851 & FJ238418 & FJ238385 \\
\hline Thelebolus sp. & I12F_02287 & JX852407 & JX852357 & - & - & - \\
\hline Arthrocladiella mougeotii & CF2012024 & KP975400 & KR048053 & - & - & - \\
\hline Blumeria graminis & MUMH1725 & - & AB273558 & - & - & - \\
\hline Brasiliomyces trina & & AB022350 & $\mathrm{AB} 022351$ & AB022349 & - & - \\
\hline Caespitotheca forestalis & MUMH1461 & AB193467 & AB193466 & AB193465 & - & - \\
\hline Cystotheca lanestris & CF2012052 & KR048117 & KR048055 & - & - & - \\
\hline Erysiphe javanica & MUMH5153 & JQ220159 & JQ220162 & - & - & - \\
\hline Erysiphe platani & KR29265 & JQ365939 & JQ365943 & - & - & - \\
\hline Golovinomyces ambrosiae & MUMH731 & AB077680 & AB077679 & - & - & - \\
\hline Leveillula sp. & MUMH805 & AB080478 & AB045156 & - & - & - \\
\hline
\end{tabular}


Supplementary Table 1 Continued.

\begin{tabular}{|c|c|c|c|c|c|c|}
\hline Species & Isolate & LSU & ITS & SSU & TEF & RPB2 \\
\hline Microidium phyllanthi & MUMH1778 & AB120754 & AB719951 & AB120753 & - & - \\
\hline Neoerysiphe geranii & CF2013083 & KR048161 & KR048092 & - & - & - \\
\hline Parauncinula septata & MUMH585 & AB183532 & AB183533 & AB183530 & - & - \\
\hline Phyllactinia alnicola & MUMH916 & AB080452 & AB080554 & - & - & - \\
\hline Pleochaeta shiraiana & MUMH36 & - & D84381 & $\mathrm{AB} 120750$ & - & - \\
\hline Podosphaera photiniae & MUMH 248 & - & NR_147412 & - & - & - \\
\hline Sawadaea tulasnei & MUMHS112 & AB193400 & AB193388 & - & - & - \\
\hline Leveillula taurica & GZP & - & KX709873 & - & - & - \\
\hline Oidium heveae & HO_473 & KY302627 & KY302626 & - & - & - \\
\hline Ovulariopsis cf. insolita & CCCUPc07 & - & $\mathrm{KC} 122682$ & - & - & - \\
\hline Pseudoidium neolycopersici & MUMH 561 & AB921990 & AB921989 & - & - & - \\
\hline Deltopyxis triangulispora & H.B. $9625 b$ & - & JQ688406 & - & - & - \\
\hline Deltopyxis triangulispora & G.M. 2016_12_06 & - & MF594688 & - & - & - \\
\hline Stamnaria americana & NBRC 108774 & AB773854 & - & AB773855 & AB773858 & AB773857 \\
\hline Discinella schimperi & M192 & EU940127 & - & EU940054 & - & EU940340 \\
\hline Hydrocina chaetocladia & HME4375 & AY789412 & AY789413 & AY789411 & - & - \\
\hline Durella macrospora & G.M. 2015_04_05 & - & KY462813 & - & - & - \\
\hline Strossmayeria basitricha & ILLS60498 & JN012016 & - & - & - & - \\
\hline Bryoclaviculus campylopi & PDD: 101074 & JX393085 & JX393084 & JX393087 & - & - \\
\hline Bryoglossum gracile & MBH52481 & AY789420 & AY789421 & AY789419 & - & - \\
\hline Cyttaria darwinii Berk. 1842 & isolate 14 & EU107208 & EU107253 & EU107181 & - & - \\
\hline Cyttaria johowii & isolate 73 & EU107229 & EU107257 & EU107198 & - & - \\
\hline Cyttaria hariotii & isolate 55 & EU107218 & - & EU107195 & EU107252 & - \\
\hline Cyttaria hookeri & isolate 60 & EU107227 & EU107256 & - & - & - \\
\hline Amorphotheca resinae & ATCC 200942 & AY352592 & NR_119450 & - & - & - \\
\hline Byssoascus striatosporus & CBS 642.66 & AB040688 & - & AJ315170 & - & - \\
\hline
\end{tabular}


Supplementary Table 1 Continued.

\begin{tabular}{|c|c|c|c|c|c|c|}
\hline Species & Isolate & LSU & ITS & SSU & TEF & RPB2 \\
\hline Byssoascus striatosporus & UAMH 3572 & - & NR_111040 & - & - & - \\
\hline Gymnostellatospora alpina & C11 & - & FJ590609 & FJ590656 & - & - \\
\hline Myxotrichum deflexum & CBS 228.61 & AB040689 & LN833542 & AB015777 & - & LN833563 \\
\hline Oidiodendron chlamydosporicum & UAMH 6520 & - & NR_111032 & - & - & - \\
\hline Oidiodendron sp. & TTC455 & KX640791 & KX640717 & - & - & - \\
\hline Pseudogymnoascus roseus & $\mathrm{CS} 20$ & - & AY608924 & - & - & - \\
\hline Connersia rilstonii & CBS 537.74 & AF096189 & KJ755499 & AF096174 & - & KJ755473 \\
\hline Leuconeurospora pulcherrima & CBS 343.76 & AF096193 & KJ755518 & AF096178 & - & KJ755491 \\
\hline Pleuroascus nicholsonii & CBS 345.73 & AF096196 & KJ755519 & AF096182 & - & - \\
\hline Pseudeurotium ovale & FMR 13600 & KP686193 & KP686192 & - & - & - \\
\hline Rhynchosporium agropyri & ZT Myc2337 & - & NR_121480 & - & - & - \\
\hline Varicosporium delicatum & CCM F_19494 & KC834036 & JQ412864 & - & - & - \\
\hline Filosporella fistucella & CCM_13091 & KC834021 & NR_153981 & - & - & - \\
\hline Meliniomyces variabilis & UAMH 10029 & - & AY838793 & AY838792 & - & - \\
\hline Chalara hyalocuspica & CCF 3975 & FR667867 & NR_137568 & - & - & - \\
\hline Rhyzoscyphus ericae & strain 111 & AM887699 & - & - & - & - \\
\hline Gyoerffyella tricapillata & CBS 451.64 & KC834030 & NR_155114 & - & - & - \\
\hline Articulospora tetracladia & CCM F_11805 & - & EU998928 & - & - & - \\
\hline Lemonniera centrosphaera & CCM F_149 & KC834032 & NR_155313 & - & - & - \\
\hline Glarea sp. & $\mathrm{C} 2 \mathrm{~B}$ & - & KX610435 & - & - & - \\
\hline Mycofalcella calcarata & CCMF 10289 & $\mathrm{KC} 834033$ & NR_154165 & - & - & - \\
\hline Infundichalara microchona & CBS 175.74 & HQ609479 & KR859078 & HQ609486 & - & KR859318 \\
\hline Phialina lachnobrachyoides & KUS_F52183 & JN086715 & JN033412 & - & - & JN086861 \\
\hline Poculum pseudosydowianum & TNS:F_40071 & AB926136 & AB904505 & - & - & AB926182 \\
\hline Clarireedia bennettii & CBS 309.37 & - & MF964321 & - & - & - \\
\hline Meria laricis & AFTOL_ID 244 & - & KT225534 & - & - & - \\
\hline
\end{tabular}


Supplementary Table 1 Continued.

\begin{tabular}{|c|c|c|c|c|c|c|}
\hline Species & Isolate & LSU & ITS & SSU & TEF & RPB2 \\
\hline Scytalidium lignicola & UAMH 1502 & - & NR_121314 & NG_061078 & - & - \\
\hline Cryptosporiopsis sp. & CBS 433.75 & GU973599 & GU973506 & - & - & - \\
\hline Rhizodermea veluwensis & CBS 110605 & KR859076 & NR_137757 & - & - & KR859353 \\
\hline Pseudofabraea citricarpa & CBS 130533 & KR859075 & KR859281 & - & - & KR859352 \\
\hline Phlyctema vagabunda & CBS 304.62 & KR859070 & KR859276 & - & KX982722 & KR859347 \\
\hline Parafabraea eucalypti & CBS: 124810 & KR858882 & KR859091 & - & KX982731 & KR859331 \\
\hline Crinula caliciiformis & AFTOL_ID 272 & AY544680 & KT225524 & AY544729 & - & KT225542 \\
\hline Alatospora acuminata & ccm_F 37194 & - & AY204590 & AY204585 & - & - \\
\hline Flagellospora curvula & CB_M13 & KC834024 & KC834045 & - & - & - \\
\hline Xeropilidium dennisii & KL159 & KX090807 & LT158422 & KX090859 & KX090660 & KX090710 \\
\hline Coleophoma proteae & CBS 132532 & NG_042679 & NR_111760 & - & - & - \\
\hline Diplococcium spicatum & CBS 852.73 & EF204496 & - & EF204513 & - & EF204483 \\
\hline Cheirospora botryospora & CPC 24607 & KR611894 & KR611872 & - & - & - \\
\hline Acidomelania panicicola & $61 \mathrm{R} 8$ & KF874622 & KF874619 & - & - & - \\
\hline Ceuthospora sp & CLX3538 & KF493763 & KF493753 & KF493743 & - & - \\
\hline Sclerencoelia fascicularis & G.M. 2016-03-09.1 & MH194576 & MH194576 & MH194576 & - & - \\
\hline Cryptosporella hypodermia & AFTOL-ID 2124 & DQ862028 & - & DQ862049 & DQ862034 & DQ862018 \\
\hline Ophiocordyceps irangiensis & OSC 128578 & DQ518770 & JN049833 & DQ522556 & DQ522345 & DQ522445 \\
\hline Ophiocordyceps gracilis & OSC 151906 & KJ878890 & - & KJ878923 & KJ878969 & - \\
\hline Ophiocordyceps variabilis & OSC 111003 & EF468839 & - & EF468985 & EF468779 & EF468933 \\
\hline Ophiocordyceps sinensis & YN09-64 & JX968033 & JQ325141 & JX968028 & - & JX968013 \\
\hline Rommelaarsia flavovirens & HB9951c & KT958771 & KT958774 & - & - & - \\
\hline Polyphilus sieberi & TT3B & MG719708 & MG719690 & MG719729 & - & MG719750 \\
\hline Scolecolachnum pteridii & CPC 24666 & KU597764 & KU597797 & - & - & - \\
\hline Zymochalara cyatheae & CPC:24736 & KU597770 & KU597803 & KU597785 & - & - \\
\hline Soosiella minima & MH_2012_1230 & JX124327 & JX124327 & JX124327 & - & - \\
\hline
\end{tabular}


Supplementary Table 1 Continued.

\begin{tabular}{|c|c|c|c|c|c|c|}
\hline Species & Isolate & LSU & ITS & SSU & TEF & RPB2 \\
\hline Cylindrosporium olivae & CBS 218.54 & MH873826 & MH857298 & - & - & - \\
\hline Rhexocercosporidium carotae & CBS 418.65 & MH870289 & NR_111086 & NG_061015 & - & - \\
\hline Cylindrosporium concentricum & CBS 157.35 & MH867125 & MH855615 & - & - & - \\
\hline Gelatinomyces siamensis & KKUK1 & JX219381 & JX219379 & JX219377 & - & - \\
\hline Lachnopsis catarinensis & CPC 24723 & KU597760 & KU597793 & KU597778 & - & - \\
\hline Bloxamia cyatheicola & VIC 42563 & KU597757 & KU597790 & KU597775 & - & - \\
\hline Lauriomyces cylindricus & SFC01649 & KX649966 & KX649977 & KX649955 & - & - \\
\hline Lauriomyces basitruncatus & $\mathrm{CC} 00049$ & KX649970 & KX649981 & KX649959 & - & - \\
\hline Satchmopsis brasiliensis & CBS 420.93 & MH874078 & DQ195784 & DQ195807 & - & - \\
\hline Fuscosclera lignicola & CBS 142287 & KY853504 & KY853444 & - & - & - \\
\hline Triposporium deviatum & CBS 137300 & KY853537 & KY853474 & - & - & - \\
\hline Acidea extrema & CCF3830 & FJ430779 & FJ430779 & FJ430779 & - & - \\
\hline Macroskyttea parmotrematis & UGDA & KP984788 & KP984784 & KP984790 & - & - \\
\hline Amphobotrys ricini & RWB 1595 & - & JX961614 & - & - & - \\
\hline Valdensinia heterodoxa & VSP4A1 & - & KU306730 & - & - & - \\
\hline Geomyces auratus & CBS 108.14 & NG_042776 & NR_111872 & - & - & - \\
\hline Miniancora allisoniensis & CCMF 30487 & - & NR_154164 & - & - & - \\
\hline Corniculariella sp. & URM 6964 & - & KF700366 & - & - & - \\
\hline Typhulochaeta japonica & & - & - & AB120752 & - & - \\
\hline Cystodendron sp. & ER20F & - & KU986824 & - & - & - \\
\hline Arbusculina fragmentans & CCMF 13486 & NG_057024 & NR_153520 & - & - & - \\
\hline Cladochasiella divergens & CCM F-13489 & - & NR_153874 & - & - & - \\
\hline Clathrosphaerina zalewskii & CBS 162.49 & - & NR_159766 & - & - & - \\
\hline Crucellisporiopsis marquesiae & CBS 138895 & MH878639 & NR_137925 & - & - & - \\
\hline Curviclavula anemophila & CBS 138123 & MH877653 & KM503089 & - & - & - \\
\hline Haplographium delicatum & CBS 196.73 & MH872362 & MH860659 & - & - & - \\
\hline
\end{tabular}


Supplementary Table 1 Continued.

\begin{tabular}{|c|c|c|c|c|c|c|}
\hline Species & Isolate & LSU & ITS & SSU & TEF & RPB2 \\
\hline Mycoarthris corallina & & - & AH009124 & AH009124 & - & - \\
\hline Dimorphospora foliicola & CBS 221.59 & MH869385 & NR_153969 & - & - & - \\
\hline Fontanospora sp. & 59_DS.ST28.FK & - & KY977554 & - & - & - \\
\hline Geniculospora grandis & & MH873440 & MH861735 & - & - & - \\
\hline Gloeotinia granigena & CBS 417.50 & MH868212 & - & - & - & - \\
\hline Helicodendron websteri & & MH874234 & MH862609 & - & - & - \\
\hline Cochlearomyces eucalypti & CBS: 142622 & MG386081 & MG386025 & - & - & - \\
\hline Epicladonia sandstedei & RP106 & KY661650 & KY661614 & KY661693 & - & - \\
\hline Exochalara longissima & CBS 980.73 & HQ609476 & - & HQ609484 & - & - \\
\hline Gorgomyces honrubiae & CCMF 12003 & $\mathrm{KC} 834028$ & NR_154062 & - & - & - \\
\hline Epithamnolia xanthoriae & Boom 52584 & KY814515 & KY814535 & KY828441 & - & - \\
\hline Leohumicola lenta & DAOM 231149 & - & NR_111180 & - & - & - \\
\hline Tetrachaetum elegans & THEL 180-1653 & - & KX858625 & - & - & - \\
\hline Xenopolyscytalum pinea & CBS 126493 & MH875581 & NR_156543 & - & - & - \\
\hline Spirosphaera minuta & CBS 475.66 & MH870502 & MH858870 & - & - & - \\
\hline Sabahriopsis eucalypti & CBS 139906 & MH878669 & NR_137991 & - & - & - \\
\hline Aquapoterium pinicola & ATCC MYA-4213 & NG_056957 & NR_111345 & - & - & - \\
\hline Rhizocladosporium argillaceum & CBS 241.67 & MH870652 & NR_145279 & - & - & - \\
\hline Phaeopyxis punctum & isolate RP95 & KY661670 & KY661643 & - & - & - \\
\hline Lareunionomyces syzygii & strain CPC 26531 & KX228338 & KX228287 & - & - & - \\
\hline Mastigosporium kitzebergense & CBS 270.69 & MH871040 & MH859306 & - & - & - \\
\hline Neolauriomyces eucalypti & culture CPC:32613 & MH327842 & MH327806 & - & - & - \\
\hline Hyalodendriella betulae & CBS 261.82 & MH873240 & MH861496 & - & - & - \\
\hline Humicolopsis cephalosporioides & CBS 645.76 & MH872792 & MH861021 & - & - & - \\
\hline Fulvoflamma eucalypti & CPC 11243 & DQ195791 & DQ195779 & DQ195802 & - & - \\
\hline Encoeliopsis rhododendri & CBS 905.69 & MH871259 & MH859479 & - & - & - \\
\hline
\end{tabular}


Supplementary Table 1 Continued.

\begin{tabular}{|c|c|c|c|c|c|c|}
\hline Species & Isolate & LSU & ITS & SSU & TEF & RPB2 \\
\hline Dactylaria dimorphospora & CBS 256.70 & MH871358 & MH859594 & - & - & - \\
\hline Crucellisporium umtamvunae & CBS 125742 & MH875124 & MH863659 & - & - & - \\
\hline Collembolispora aristata & CPC 21145 & KC005811 & NR_111830 & - & - & - \\
\hline Brefeldochium pruinosum & CBS 111544 & MH874458 & MH862876 & - & - & - \\
\hline Brachyalara straminea & CBS 622.82 & HQ609475 & - & HQ609482 & - & - \\
\hline Scytalidium vaccinii & CBS 652.89 & MH873881 & MH862193 & - & - & - \\
\hline Neocrinula xanthorrhoeae & CPC 29474 & NG_059743 & KY173412 & - & - & - \\
\hline Clathrosporium intricatum & ICMP:14611 & - & EF029191 & - & - & - \\
\hline Strasseria geniculata & CBS 132.65 & MH870153 & MH858519 & - & - & - \\
\hline Collophorina euphorbiae & IBRC-M 30208 & MG592738 & MG592740 & MG592742 & - & - \\
\hline Xenochalara juniperi & cmw1901 & - & AF184889 & - & - & - \\
\hline Porodiplodia livistonae & culture CPC:32154 & MH327845 & MH327809 & - & - & - \\
\hline Davidhawksworthia ilicicola & CBS 734.94 & KU728556 & NR_154008 & - & KU728592 & - \\
\hline Vandijckella johannae & JW1033 & LT904726 & LT904725 & - & - & LT904707 \\
\hline Epiglia gloeocapsae & CBS 126302 & MH875424 & MH863969 & - & - & - \\
\hline Epiglia gloeocapsae & CBS 126301 & MH875423 & MH863968 & - & - & - \\
\hline Pseudohelotium pineti & CBS 251.60 & MH869527 & - & - & - & - \\
\hline Lichinodium ahlneri & SL129 & MK228847 & - & MK225515 & - & - \\
\hline Lichinodium sirosiphoideum & SL91 & MK228845 & - & MK225517 & - & MK244604 \\
\hline Lichinodium sirosiphoideum & SL92 & MK228846 & - & MK225516 & - & MK244603 \\
\hline Potebniamyces pyri & CBS 322.63 & KJ663900 & KJ663859 & - & - & KJ663940 \\
\hline Mycosymbioces mycenaphila & OSC 148294 & - & NR_137807 & - & - & - \\
\hline Claussenomyces olivaceus & NB_479 & KY633629 & KY633590 & - & - & - \\
\hline Micraspis acicola & NB-366-3A & KY633626 & KY633586 & - & - & - \\
\hline Micraspis acicola & NB-505-2I & KY633624 & KY633584 & - & - & - \\
\hline Cistella granulosella & MFLU 16-0565 & MK591962 & MK584936 & MK585023 & & - \\
\hline
\end{tabular}


Supplementary Table 1 Continued.

\begin{tabular}{|c|c|c|c|c|c|c|}
\hline Species & Isolate & LSU & ITS & SSU & TEF & RPB2 \\
\hline Lachnum controversum & MFLU 18-1820 & MK591964 & MK584937 & MK585025 & & MK368613 \\
\hline Pulvinata tomentosa & MFLU 18-1819 & MK591965 & MK584938 & MK585026 & & MK373054 \\
\hline Cadophora microspora & MFLU 18-2672 & MK591966 & MK584939 & MK585027 & & MK373055 \\
\hline Lanceolata brunnea & MFLU 18-1821 & MK591967 & MK584940 & MK585028 & MK637044 & MK373056 \\
\hline Calloria urticae & MFLU 18-0696 & MK591968 & MK584941 & MK585029 & MK637045 & MK373057 \\
\hline Calloria urticae & MFLU 18-0697 & MK591969 & MK584942 & MK585030 & MK637046 & MK373058 \\
\hline Cyathicula cyathoidea & MFLU 18-0698 & MK591970 & MK584943 & MK585031 & MK637047 & MK388217 \\
\hline Crocicreas sp & MFLU 18-1822 & MK591963 & MK584944 & MK585024 & & - \\
\hline Rhexocercosporidium $s p$ & MFLU 16-0559 & MK591961 & MK584945 & MK585022 & MK637048 & MK368612 \\
\hline Unguiculella globosa & MFLU 18-1816 & MK591972 & MK584946 & MK585044 & MK714027 & MK614727 \\
\hline Dicephalospora sessilis & MFLU 18-1823 & MK591974 & MK584947 & MK585047 & MK714028 & MK577779 \\
\hline Erioscyphella fusiforme & MFLU 18-1824 & MK591975 & MK584948 & - & & MK614728 \\
\hline Dicephalospora rufocornea & MFLU 18-1825 & MK591976 & MK584949 & MK585048 & MK714030 & MK614729 \\
\hline Erioscyphella abnormis & MFLU 18-1826 & MK591977 & MK584950 & MK585049 & & MK614730 \\
\hline Erioscyphella sclerotii & MFLU 16-0569 & MK591980 & MK584951 & MK585033 & & MK388219 \\
\hline Bisporella discedens & MFLU 18-2673 & MK591982 & MK584952 & MK585035 & & - \\
\hline Erioscyphella brasiliensis & MFLU $16-0577 \mathrm{a}$ & MK591983 & MK584953 & MK585036 & & MK388221 \\
\hline Terriera elliptica & MFLU 16-0582 & - & MK584954 & - & & - \\
\hline Dicephalospora rufocornea & MFLU 16-0585 & MK591984 & MK584955 & - & MK714021 & MK388222 \\
\hline Proliferodiscus chiangraiensis & MFLU 16-0588 & MK591985 & MK584956 & MK585037 & & - \\
\hline Erioscyphella aseptata & MFLU 16-0590 & MK591986 & MK584957 & - & & MK388223 \\
\hline Dicephalospora aurantiaca & MFLU 16-0591b & - & MK584958 & MK585038 & MK714024 & MK614722 \\
\hline Dicephalospora rufocornea & MFLU 18-0674a & - & MK584959 & - & MK714023 & - \\
\hline Dicephalospora rufocornea & MFLU 18-0674b & MK591989 & MK584960 & MK585039 & MK689342 & - \\
\hline Dicephalospora rufocornea & MFLU 18-0675 & MK591987 & MK584961 & - & MK714022 & MK614723 \\
\hline Dicephalospora aurantiaca & MFLU 16-0591a & MK591988 & MK584962 & - & & - \\
\hline
\end{tabular}


Supplementary Table 1 Continued.

\begin{tabular}{|c|c|c|c|c|c|c|}
\hline Species & Isolate & LSU & ITS & SSU & TEF & RPB2 \\
\hline Rubropezicula thailandica & MFLU 16-0592 & - & MK584963 & - & & - \\
\hline Strossmayeria bakeriana & MFLU 16-1862 & MK591971 & MK584964 & MK585032 & & MK614732 \\
\hline Erioscyphella alba & MFLU 16-0614 & MK591990 & MK584965 & - & & - \\
\hline Hymenoscyphus cf calyculus & MFLU 16-1865 & MK591991 & MK584966 & - & & - \\
\hline Erioscyphella brasiliensis & MFLU $16-0577 \mathrm{~b}$ & MK591993 & MK584967 & MK585040 & & - \\
\hline Chlorociboria poutoensis & MFLU 18-0676 & MK591994 & MK584968 & MK585041 & MK714025 & MK614725 \\
\hline Erioscyphella sclerotii & MFLU 18-0688 & MK591995 & MK584969 & MK585042 & & MK614726 \\
\hline Bisporella discedens & MFLU 18-0691 & MK591996 & MK584970 & MK585043 & MK714026 & - \\
\hline Bisporella shangrilana & HKAS $90655 b$ & MK591997 & MK584971 & MK585052 & MK637049 & - \\
\hline Bisporella shangrilana & HKAS 90655a & MK591998 & MK584972 & MK585053 & MK637050 & - \\
\hline Ascocoryne sarcoides & HKAS 90651 & MK591999 & MK584973 & MK585054 & MK637051 & MK614731 \\
\hline Banksiamyces sp & HKAS 90000 & MK592000 & MK584974 & MK585055 & & MK388218 \\
\hline Scolecolachnum nigricans & MFLU 18-1817 & MK591973 & MK584975 & MK585045 & & - \\
\hline Helicogoniaceae $s p$ & $\mathrm{HCO6-b}$ & - & MK584976 & MK585046 & & - \\
\hline Dicephalospora rufocornea & MFLU 18-1832 & - & MK584977 & - & MK714029 & MK577780 \\
\hline Dicephalospora rufocornea & MFLU 18-1827 & MK591978 & MK584978 & MK585050 & MK714031 & MK577781 \\
\hline Dicephalospora huangshanica & MFLU $18-1828$ & MK591979 & MK584979 & MK585051 & MK714032 & MK577782 \\
\hline Vibrissea brevistipitata & MFLU 16-0597 & - & MK584980 & - & & - \\
\hline Neopyrenopeziza nigripigmentata & MFLU 16-0599 & MK592001 & MK584981 & MK585057 & & - \\
\hline Duebenia subcompta & MFLU 16-0600 & MK592002 & MK584982 & MK585058 & MK714033 & - \\
\hline Duebenia compta & MFLU 16-0601 & MK592003 & MK584983 & MK585059 & & - \\
\hline Neofabraea brunneipila & MFLU 15-0231 & MK592004 & MK584984 & MK585060 & & - \\
\hline Lophodermium herbarum & MFLU 16-0877 & MK592005 & MK584985 & MK585061 & & - \\
\hline Chalara sp & MFLU 18-1812 & MK592006 & MK584986 & MK585017 & & - \\
\hline Chalara $s p$ & MFLU 18-1813 & MK592007 & MK584987 & MK585056 & & - \\
\hline Crocicreas cf tomentosum & MFLU 17-0082 & MK592008 & MK584988 & MK585062 & & - \\
\hline
\end{tabular}


Supplementary Table 1 Continued.

\begin{tabular}{|l|l|l|l|l|l|l|}
\hline Species & Isolate & LSU & ITS & SSU & TEF & RPB2 \\
\hline Dicephalospora rufocornea & MFLU 16-1860 & MK592011 & MK584989 & MK585064 & & - \\
\hline Chlorociboria olivaceous & MFLU 18-1814 & MK592009 & MK584990 & - & MK714034 & - \\
\hline Dicephalospora rufocornea & MFLU 16-1858 & MK592010 & MK584991 & MK585063 & & - \\
\hline Capitotricha filiformis & MFLU 15-2784 & - & MK584992 & MK585015 & & - \\
\hline Trimmatostroma betulinum & MFLU 15-2991 & MK591956 & MK584993 & MK585016 & & - \\
\hline Lophodermium microsporum & MFLU 15-3100 & - & MK584994 & MK585019 & & - \\
\hline Chalara sp & MFLU 15-3167 & MK591953 & MK584995 & MK585010 & MK348529 & MK310262 \\
\hline Trimmatostroma salicis & MFLU 18-0702 & - & MK584996 & - & & - \\
\hline Bacilliformis hyalinus & MFLU 18-1811 & MK591951 & MK584997 & - & & MK310263 \\
\hline Cyathicula cyathoidea & MFLU 16-0613 & MK591957 & MK584998 & MK585012 & MK637041 & - \\
\hline Rhexocercosporidium sp & MFLU 15-2755 & - & $\mathbf{M K 5 8 4 9 9 9}$ & MK585013 & & - \\
\hline Heterosphaeria linariae & MFLU 15-2764 & MK591955 & MK585000 & MK585014 & MK637042 & MK343131 \\
\hline Bacilliformis hyalinus & MFLU 18-2671 & MK591952 & MK585001 & - & & MK341543 \\
\hline Rhytisma acerinum & MFLU 15-3084 & MK591958 & MK585002 & MK585018 & & - \\
\hline Cadophora lacrimiformis & MFLU 16-1486 & MK591959 & MK585003 & MK585020 & & - \\
\hline Neomollisia gelatinosa & MFLU 18-0701 & MK591960 & MK585004 & MK585021 & MK637043 & MK358463 \\
\hline Lophodermium herbarum & MFLU 15-3182 & MK591954 & - & MK585011 & & - \\
\hline Erioscyphella fusiforme & MFLU 15-0230 & MK591981 & NR_154122 & MK585034 & & MK388220 \\
\hline Microglossum macrosporum & MFLU 18-1830 & MK591992 & - & - & - & MK614724 \\
\hline & & & &
\end{tabular}

